مدى سلطة ولي الأمر في فرض إعاشة الناس بعضهم لبعض في زمن المحاعة : دراسة فقهية مقارنة

د/ أحمد جمعة - الأستاذ المساعد بكلية الآداب - جامعة كفر الشيخ .

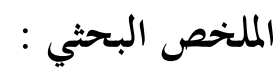

* عنو ان البحث : مدى سلطة ولي الأمر في فرض إعاشة الناس بعضهم لبعض في زمن

$$
\begin{aligned}
& \text { البحاعة - دراسة فقهية مقارنة . }
\end{aligned}
$$

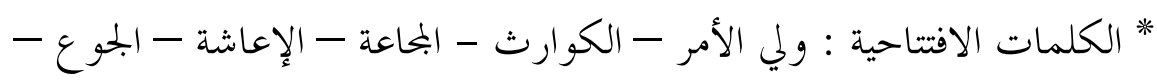$$
\text { الضريبة . n }
$$

*هدفت هذه الدراسة إلى بيان حدود سلطة ولي الأمر في فرض إعاشة الناس بعضهم لبعض في زمن البحاعة ، وما يتعلق بذلك من قضايا ، وما يرد عليه من قيود .

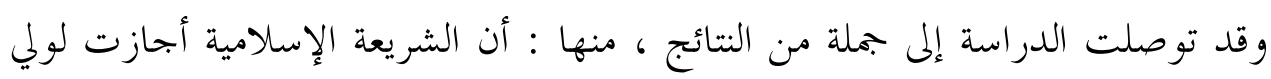

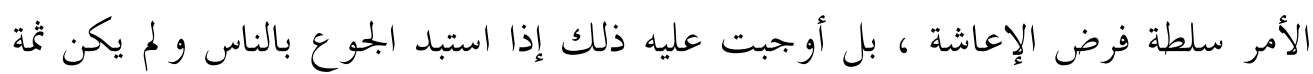

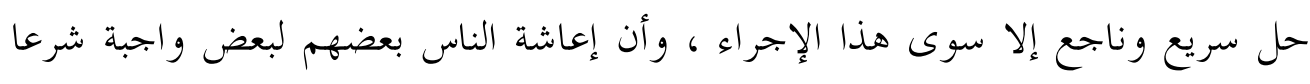

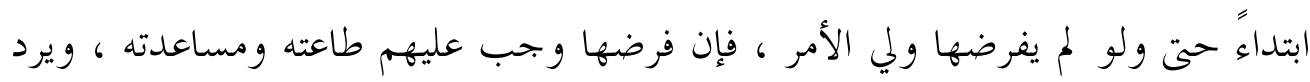
على حق ولي الأمر في هذا الاجراء بعض القيود ، منها : تحقق وقوع البحاعة فعلا، وخلو

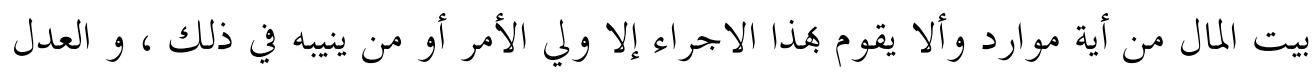

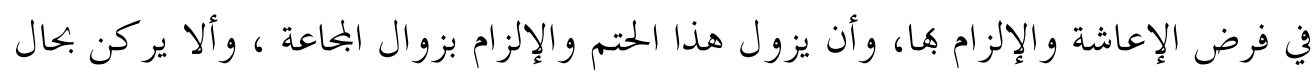

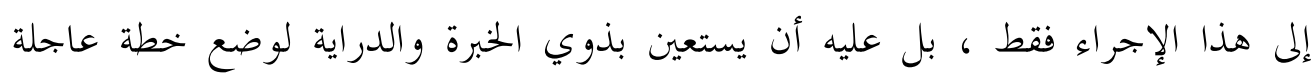
وحاسمة لإنقاذ البلاد و العباد .

\section{Abstract search:}

*search title : The extent of the guardian's authority to impose people to live with one another in times of famine - a comparative juristic study.

* The opening words : guardian - disasters - famine - subsistence - hunger tax. 
* This study aimed to show the limits of the guardian's authority to impose people to live with one another in times of famine, and related issues, and the restrictions to which he is responding.

The study reached a number of results, including that Islamic law permitted the guardian to impose subsistence, and rather obligated him to do so if people starved to hunger and there was no quick and effective solution except this procedure. And that people living with each other is obligatory in the beginning, even if the guardian did not impose it, so if they imposed it, they must obey and help him. There are some restrictions on the right of the guardian in this procedure, including: The famine actually took place, the money house is free of any resources, and only this guardian or his representative is required to do this, and fairness in imposing and And that this imperative goes away and compels the demise of famine, and does not depend in any way on this measure alone. Rather, it must seek the help of the experienced and knowledgeable to formulate an urgent and decisive plan to save the country and the people. 


\section{مقدمة}

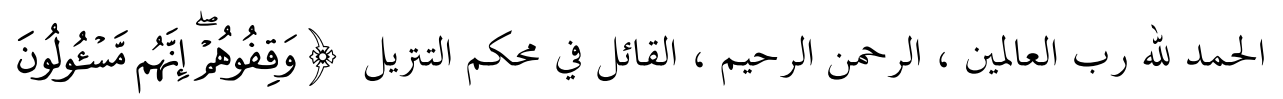

")

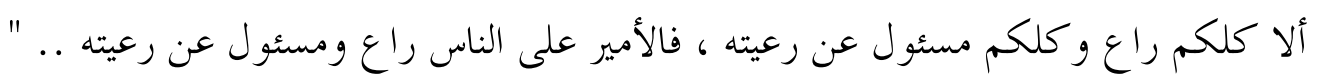

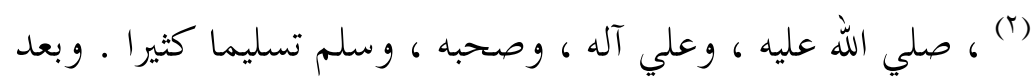

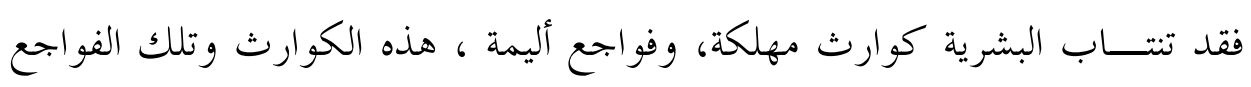

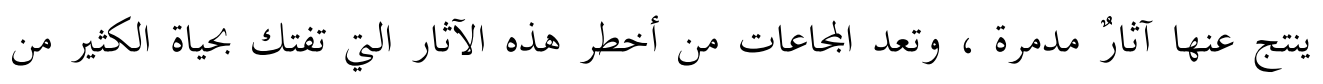

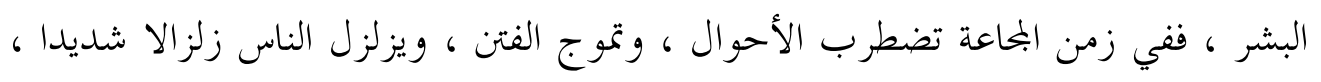

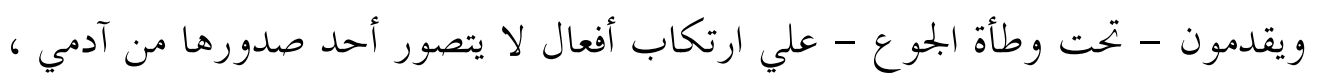

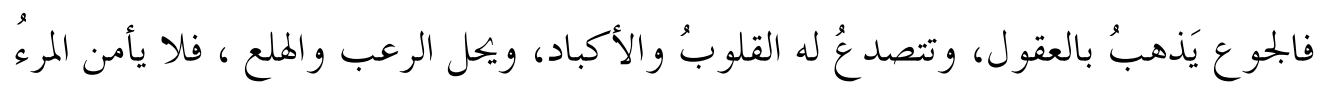

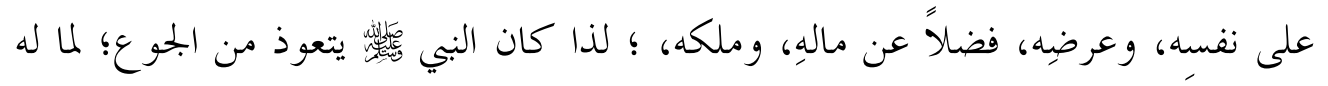

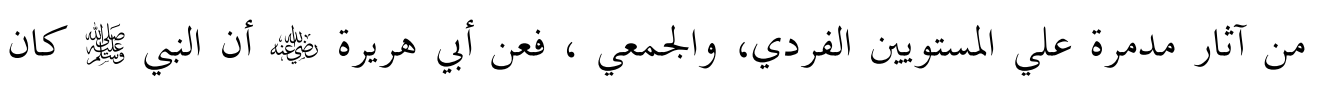

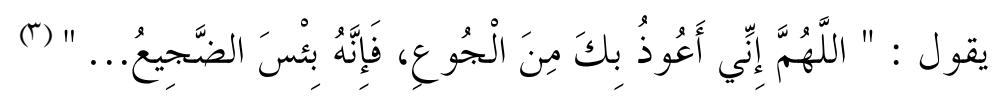

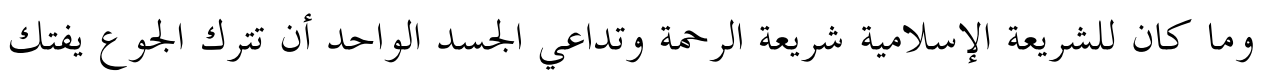

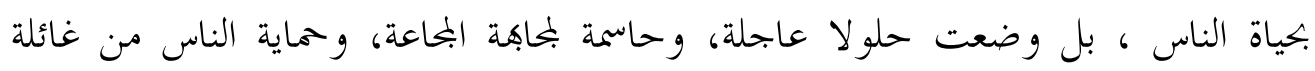

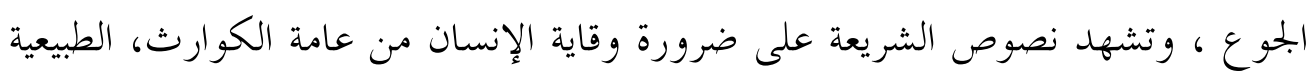

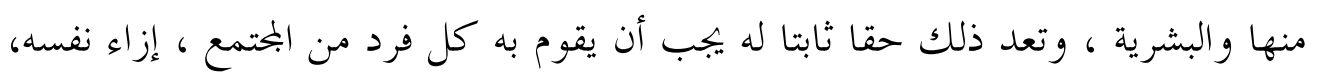

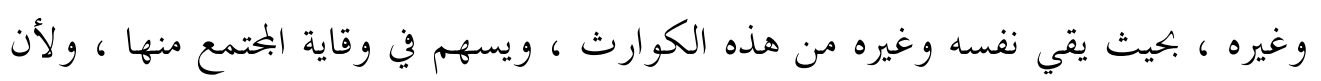

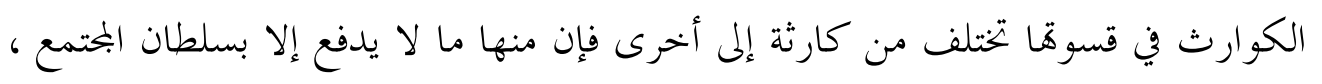

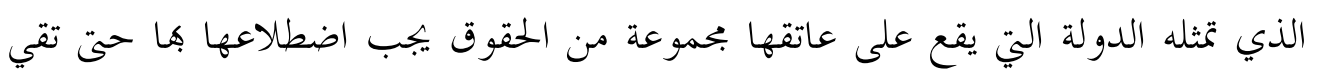

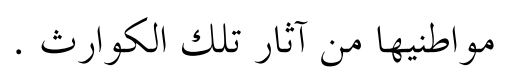

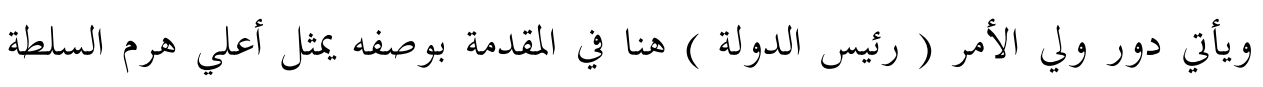

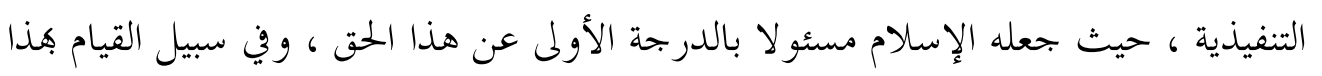


الحق أعطته الشريعة الإسلامية سلطة اتخاذ كافة القرارات و الاجراءات و التدابير المناسبة

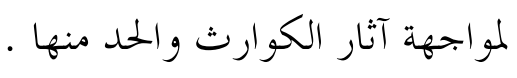

وفي هذا البحث عرض لمدي شرعية تصرف من التصرفات التي يمكن أن يقوم هـا ولي

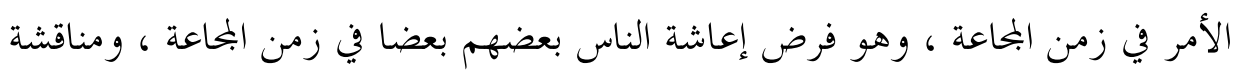
ذلك، وما قد يتعلق بذلك من قضايا .

\section{أهية الموضوع :}

1- - كثرة وقوع الكوارث في عصرنا الحاضر خحاصة النابتة عن فعل الإنسان

$$
\text { كالحروب و التلوث }
$$

r - ما يترتب على هذه الكوارث من آثار مدمرة تستوجب استنفار الهمم

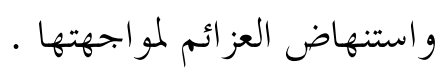

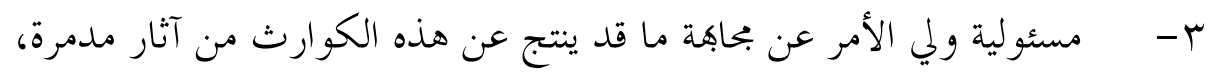

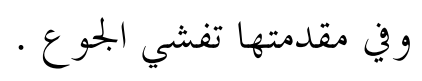

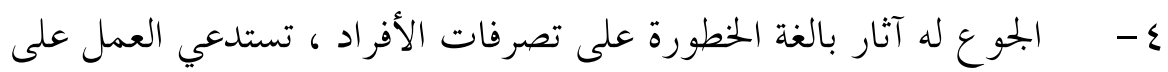

$$
\begin{aligned}
& \text { مكافحته، والحد من آثاره . } \\
& \text { أسباب اختيار الموضوع : }
\end{aligned}
$$

بالإضافة إلى ما سبق في أهمية الموضوع عقد دفعين إلى دراسة هذه المسألة ما يلي :

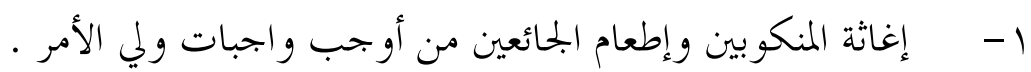

r - - أهمية فرض الإعاشة كإجراء سريع لإنقاذ الجوعى من الأطفال و النساء وغيرهم

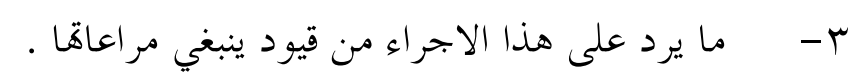

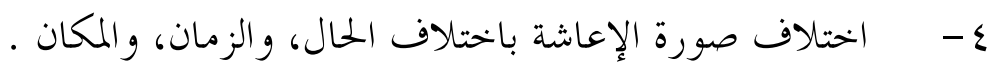

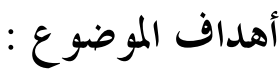

1 - بيان أثر الجموع في تصرفات الأفراد، وما يختلف فيه زمن المجاعة عن غيره من

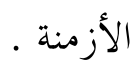

r - توضيح واجبات ولي الأمر بوجه عام، وفي زمن المحاعة بوجه خحاص . 
r- بحلية المراد بالإعاشة، وحكمها الشرعي، وصورها، و كيفية تطبيقها .

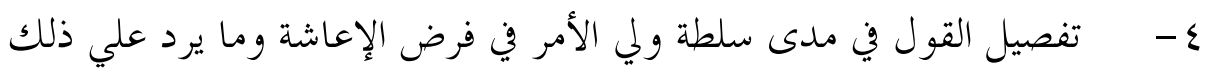

$$
\text { من قيود . }
$$

0 - معرفة بعض معالم المنهج الإسلامي في معالجة تفشي الجوع، و الحدد من آثاره المدمرة .

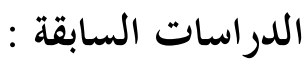

لم أجد - حسب اطلاعي القاصر - بحثا تناول نفس الموضوع ، بيد أن هناك أبحاثا

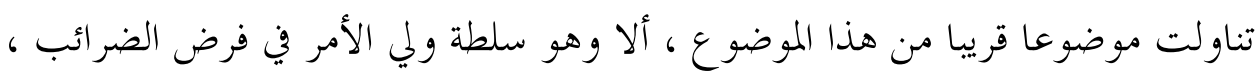

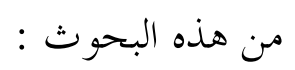

- - سلطة ولي الأمر في فرض وظائف مالية " الضرائب " ، دراسة فقهية مقارنة ،

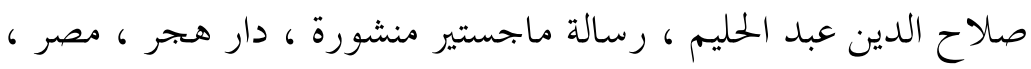

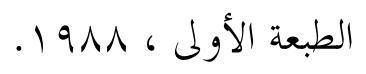

r - الخراج و الضريبة المعاصرة في الفقه الإسلامي ،دراسة مقارنة ، رسالة دكتوراه

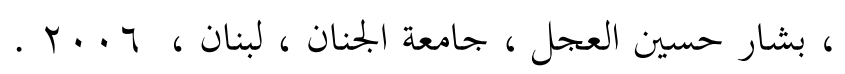

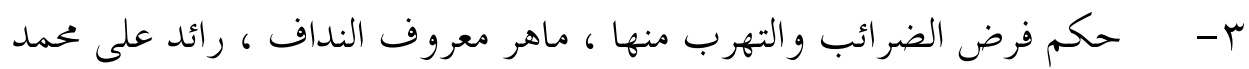

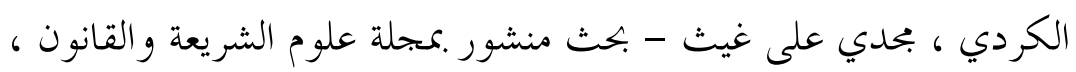

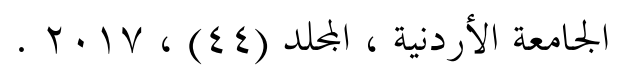

وتتفق هذه البحوث مع هذا البحث في تناول الكل لمسألة من المسائل المتعلقة بولي

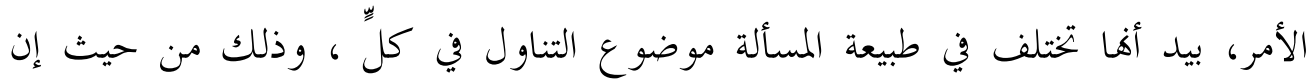
الضرائب جزء مقدر يفرض في الأموال، ويؤخذ سنويا، ويوضع في خزينة الدولة، وينفق

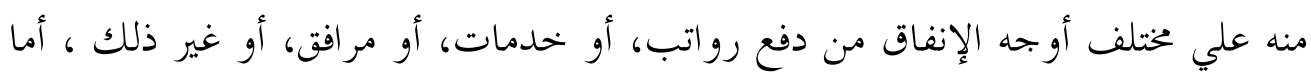

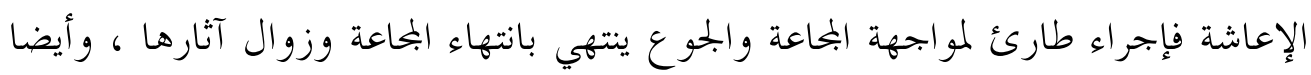
فليس لإعاشة قدر محدد فقد تمتد الإعاشة لأن يعيش الجميع علي نصف احتياجاهم ، هذا بالإضافة إلى اختلافهما في الحكم الشرعي، و كثير من التفصيلات الخاصة بكل منهما . 


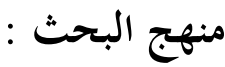

يقوم البحث علي إتباع المنهج الاستقرائي، والتحليلي، والاستباطي، من حيث استقراء

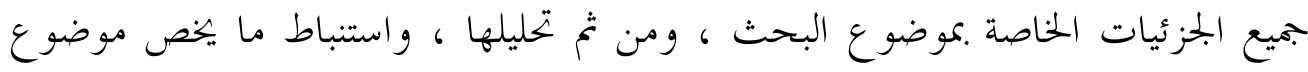

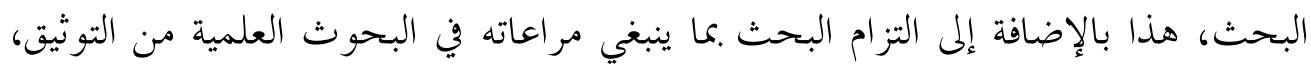

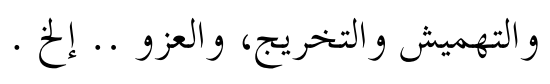

حدود البحث : يقتصر البحث على مسألة واحدة ألا وهي مدى سلطة ولي الأمر في

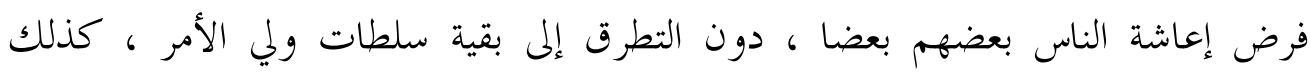

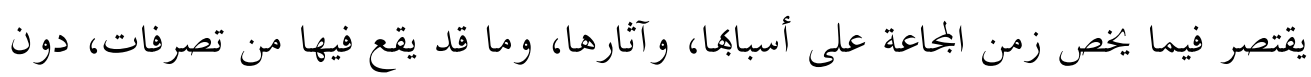
تطرق إلى بيان حكم هذه التصرفات .

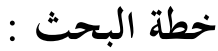

يشتمل البحث على مقدمة ، و ثلاثة مباحث ، وخاتمة

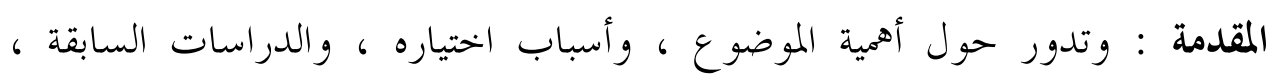
وأهداف البحث ، ومنهجه ، و وحدوده ، و وخطته .

المبحث الأول : ويدور حول التعريف بمفردات العنوان ، وفيه عدة مطالب :

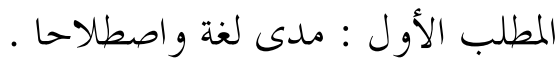

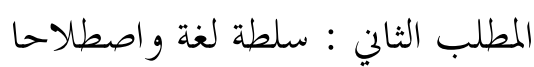
المطلب الثالث : ولي الأمر لغة واصطلاحا . الفال

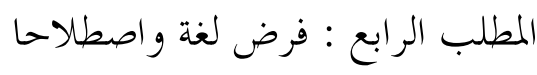
المطلب الخامس : إعاشة لغة واصطلاحا .

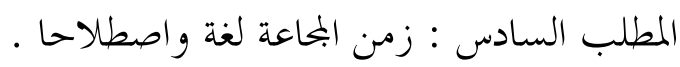

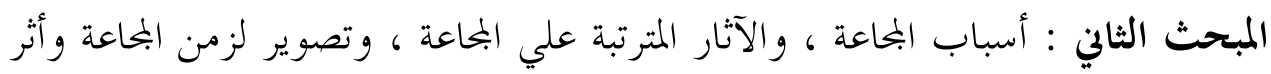

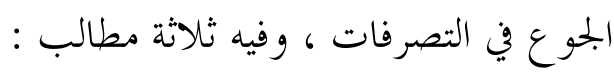

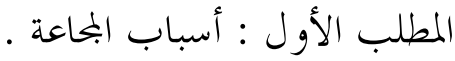

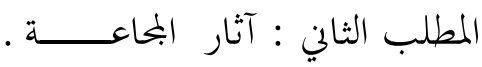


المطلب الثالث : زمن المحاعة وأثر الجوع في التصرفات .

المبحث الثالث : مدى سلطة ولي الأمر في فرض الإعاشة .

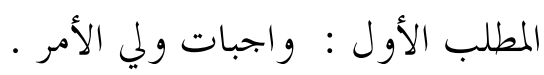

المطلب الثاني : سلطته في فرض الإعاشة .

المطلب الثالث : ضو ابط فرض الإعاشة .

المطلب الرابع : صور فرض الإعاشة .

الحاتمة : وتضم أبرز النتائج وأهم التوصيات .

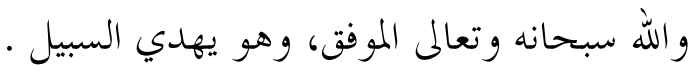

المبحث الأول : ويدور حول التعريف بمفردات العنوان ، وفيه عدة مطالب :

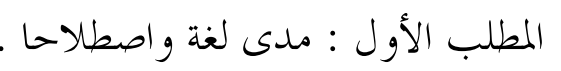

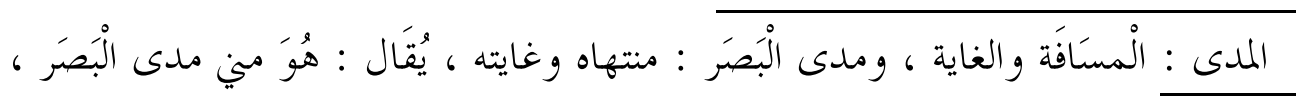

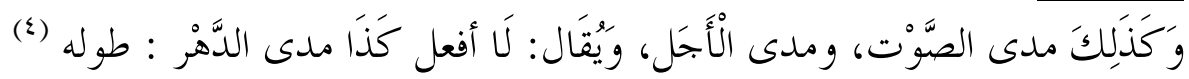
والمراد بالمدى في البحث : حدود تصرف ولي الأمر في فرض الإعاشة في زمن البحاعة .

المطلب الثاني : سلطة لغة واصطلاحا :

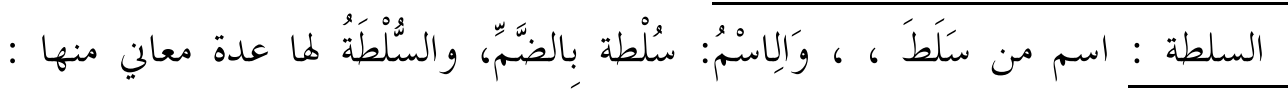

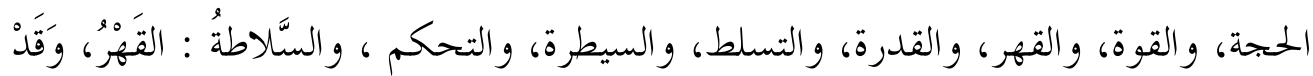

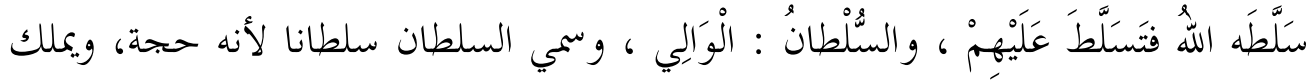

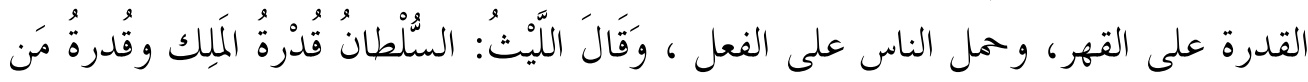

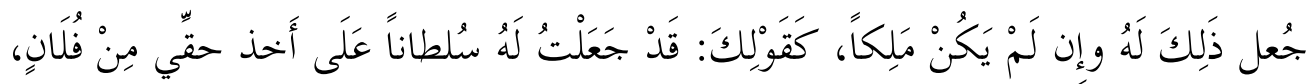

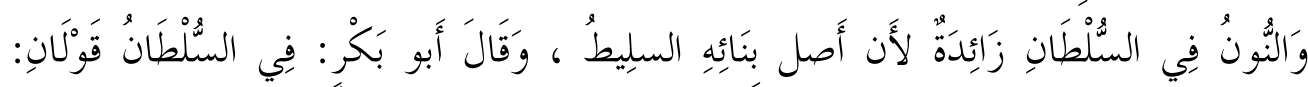

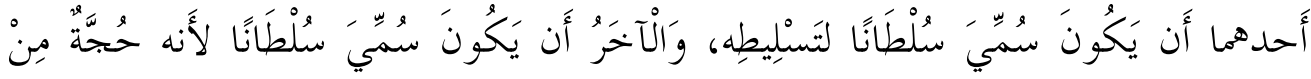

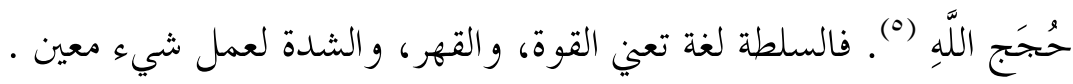
السلطة اصطلاحا : القدرة على اتخاذ القرار، والتصرف الملزم على الآخرين ، فهي التي

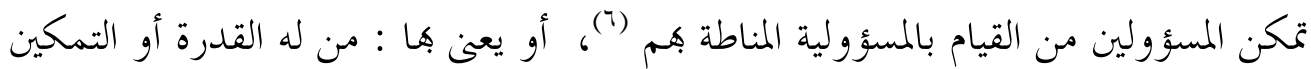


في فعل شيء، سواء كان هذا التمكين أو القدرة مصدره الشريعة الإسلامية، أم أن مبناه

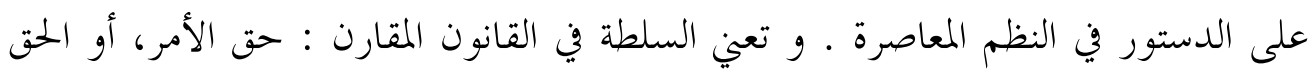

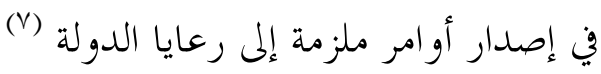

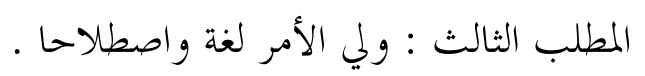

ولي الأمر في اللغة : مصطلح مكون من مفردتين ، ( ولي ) ، و و ( الأمر ) ، ، والوَّبّيُ

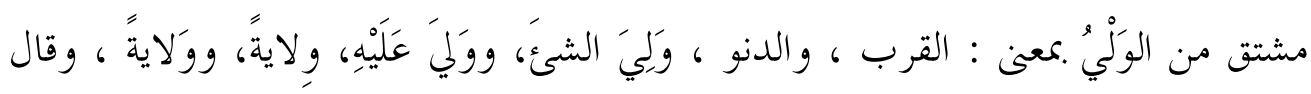

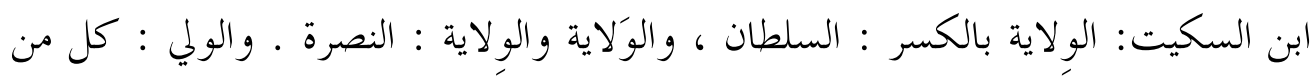

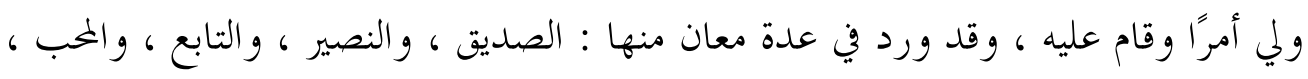

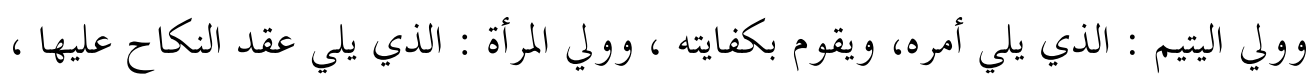

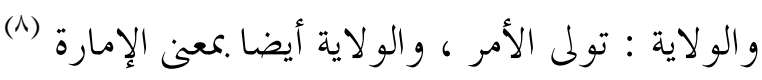

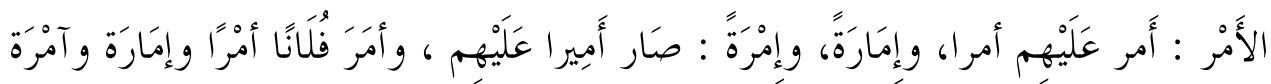

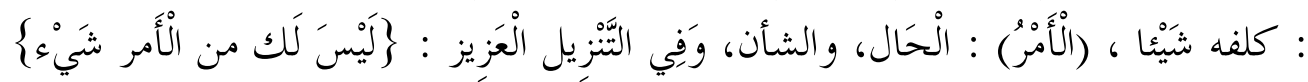

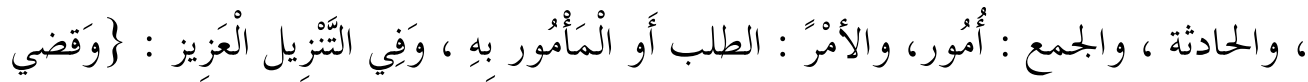

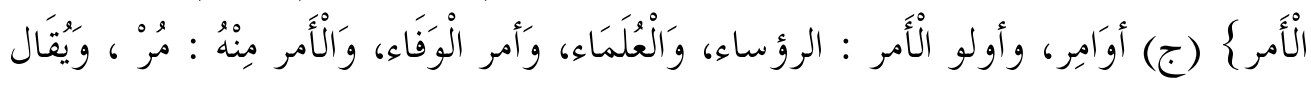

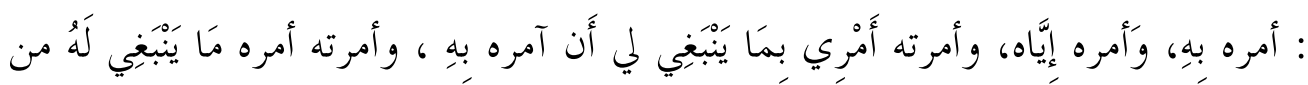

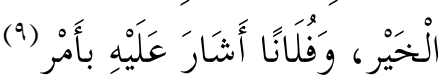

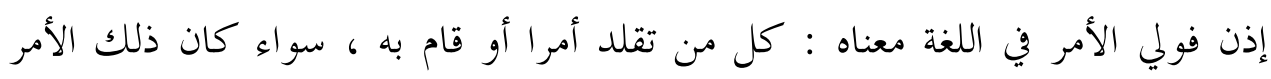

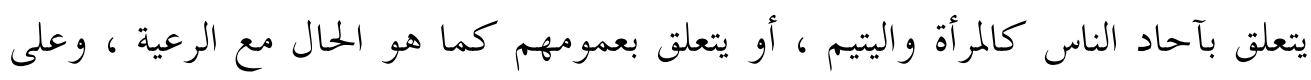

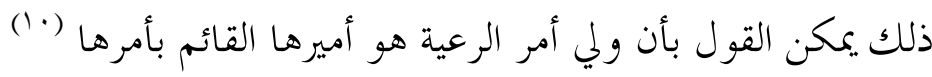

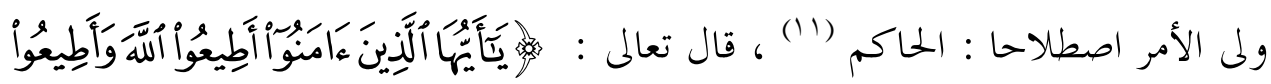

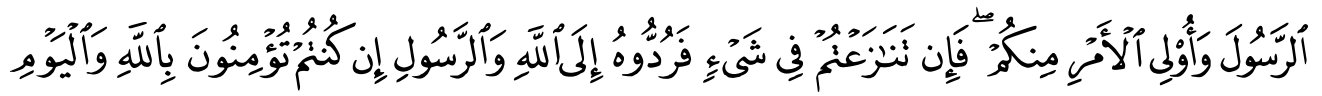

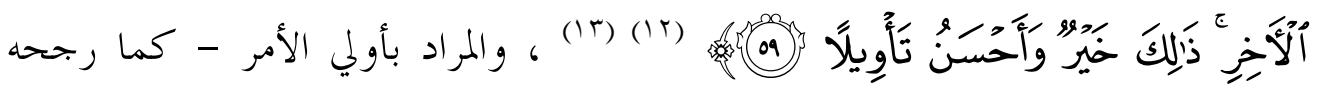

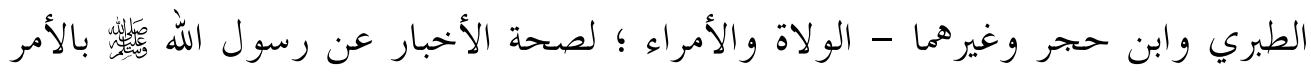


بطاعة الأئمة والو لاة فيما كان للّ طاعة، ولمسلمين مصلحة (\{) ، وبناء على ذلك ذهب

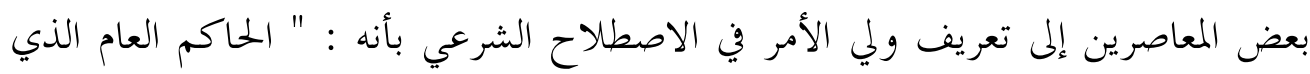

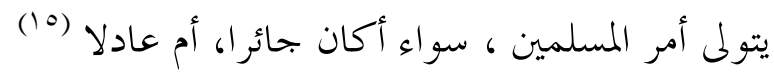

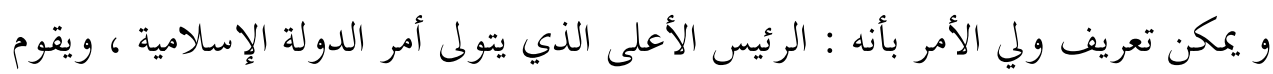

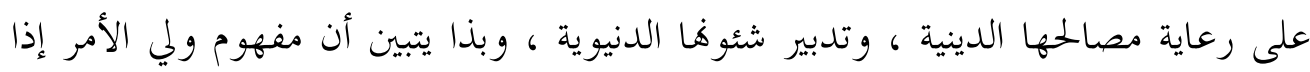

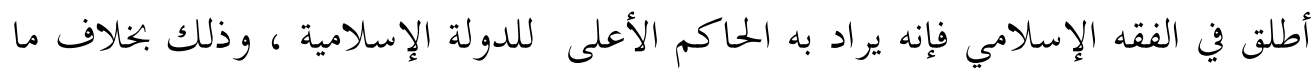

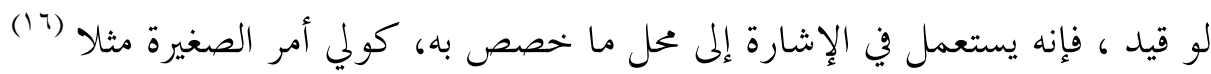

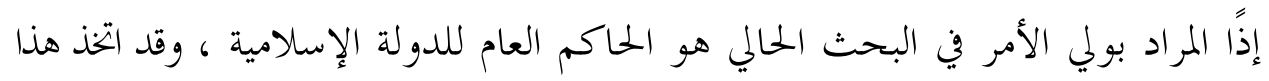

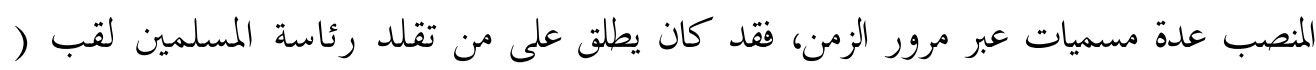

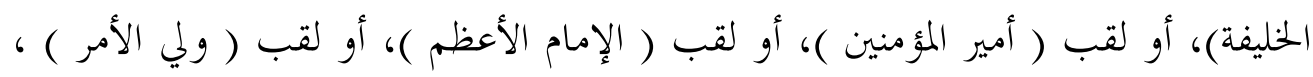

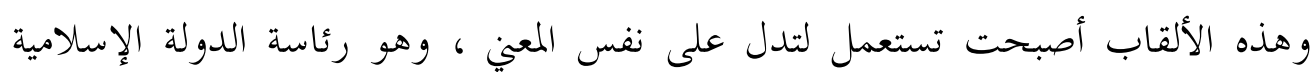

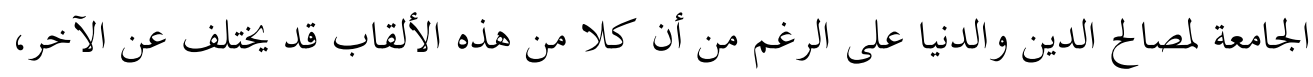

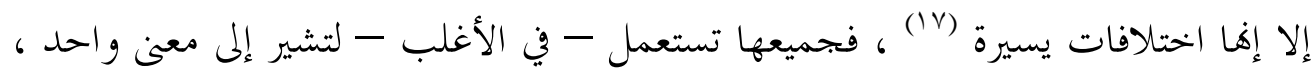

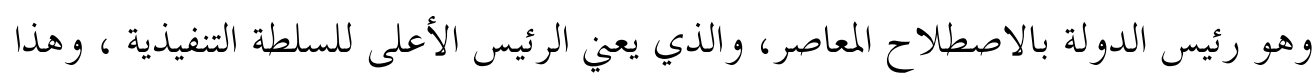

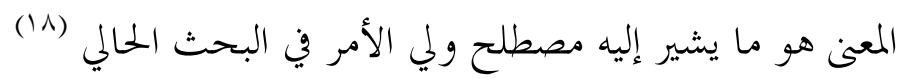

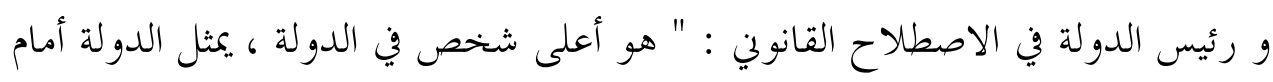

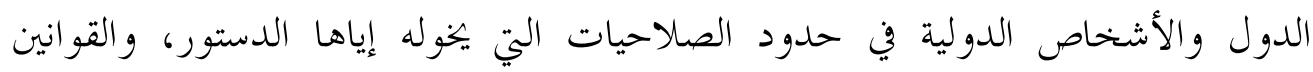
الداخلية، والأعراف الدولية (19)

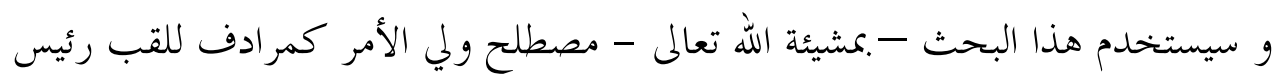

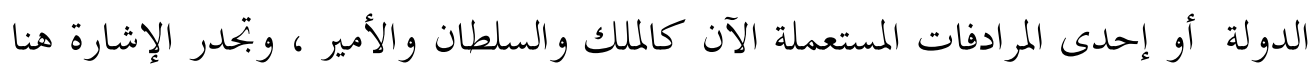

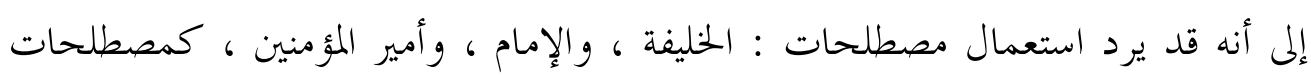

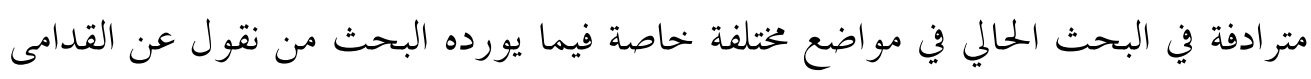

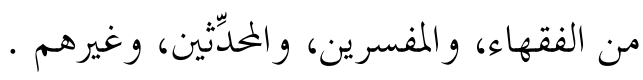
المطلب الر ابع : فرض لغة واصطلاحا : 
فرض : أوجب ، و ألزم ، فرض الأمر: أوجبه ، والفرض : ما أوجبه الله عز وجل على ( اللى

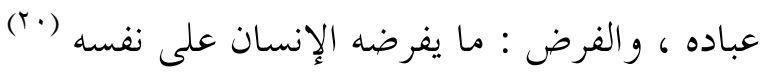

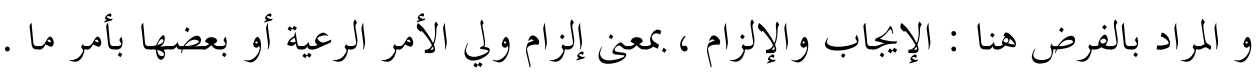
المطلب الخامس : إعاشة لغة واصطلاحا :

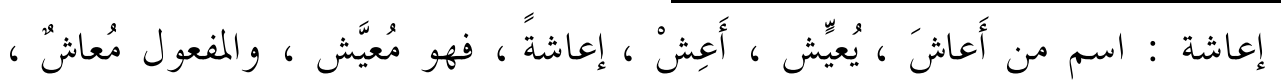

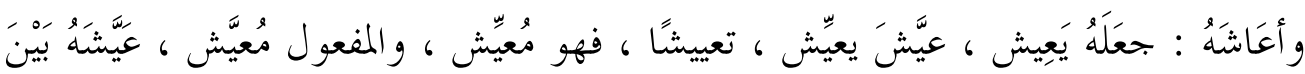

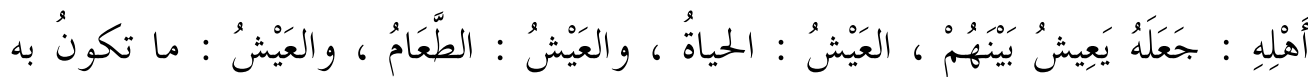

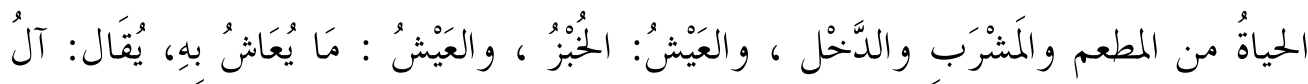

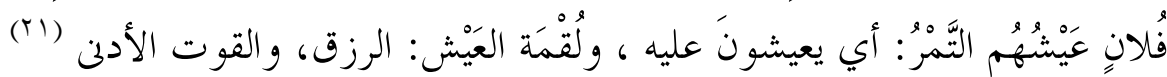

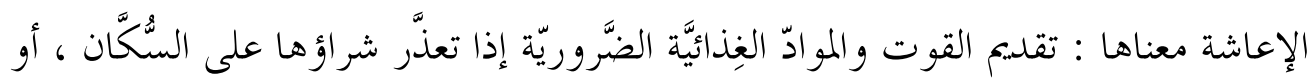

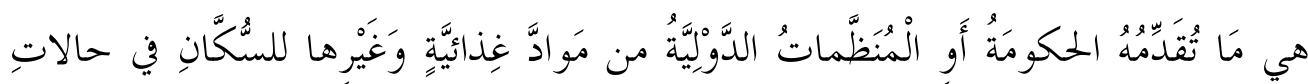

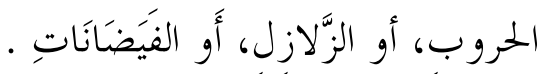

و المقصود بإعاشة الناس بعضهم بعضا : تقديم بعض الناس القوت والمواد الغذائية الضرورية للبعض الآخر ممن يعانون الجوع وقت تفشي البحاعة بسبب كارثة من الكوارث ،

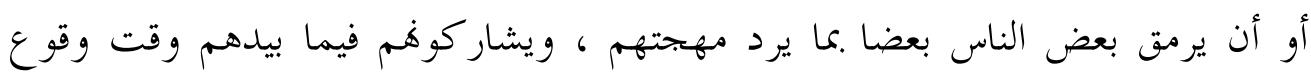

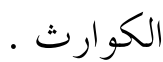
فرض الإعاشة معناه: الإلزام بسد الحاجات الضرورية من الطعام، ثم الملبس، ثم المسكن ،

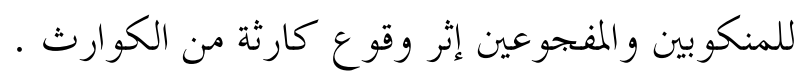
المطلب السادس : زمن المجاعة لغة واصطلاحا :

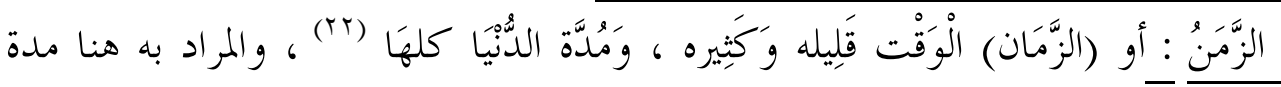

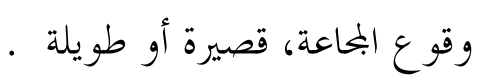

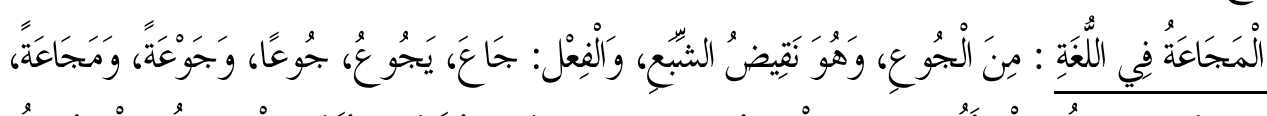

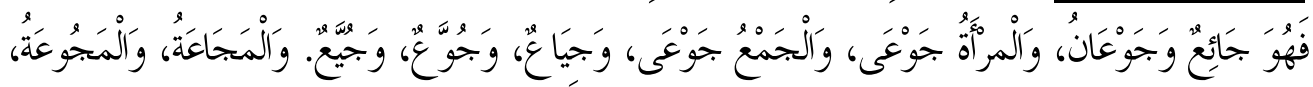

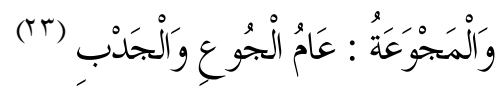


أما التعريف الاصطلاحي فلا يخرج عن التعريف اللغوي ، فالمحاعة زمن الجوع والقحط

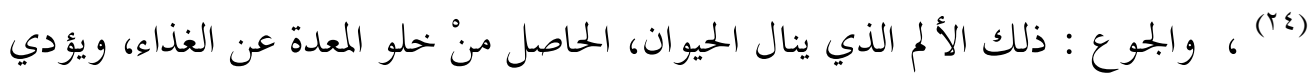

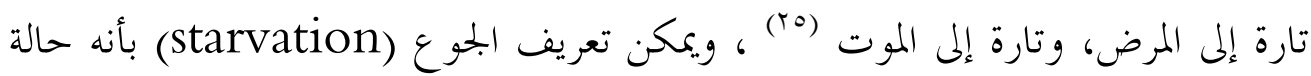
تصيب الجسم عندما يحصل على إمداد غير كاف من السعرات الحرارية، والمواد المغذية

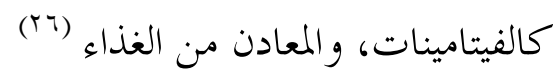

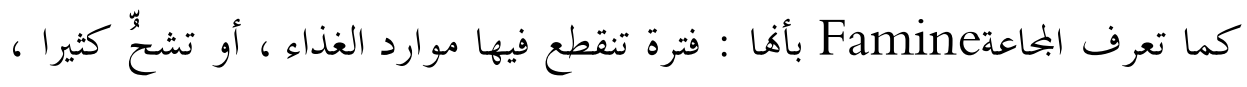
ويترتّب على ذلك نقص شديد في الطعام لمدة طويلة، ويؤدي هذا النقص الحاد في الطعام

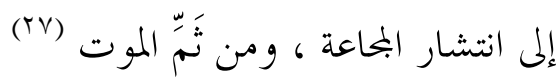
وبغية تصنيف حالة البحاعة يستخدم النظام المتكامل لتصنيف مراحل الأمن الغذائي مؤشرات متعددة القطاعات تأخذ في الاعتبار الجوانب المتعددة الأبعاد للأمن الغذائي : معدل الوفيات الأوَّلية، سوء التغذية الحاد ، التقزم ، الحصول على الأغذية وتوافرها ،

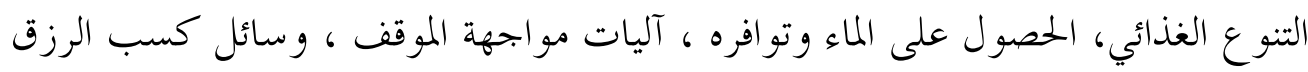

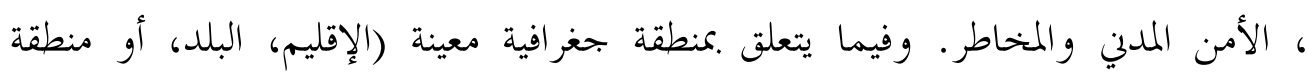
محصورة ) ، عندئذ يقوم النظام المتكامل لتصنيف مراحل الأمن الغذائي وفقًا للمستويات

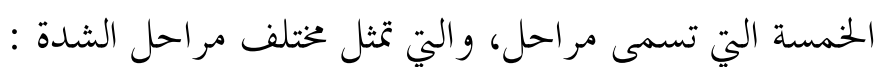

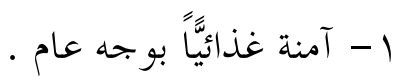

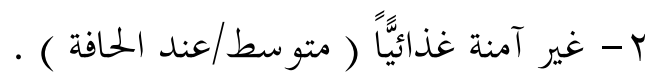

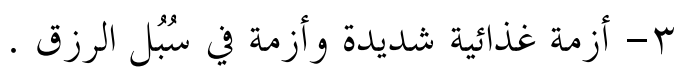
ع - حالة طوارىئ إنسانية . ه - مباعة/ كارثة إنسانية.

ويحدد النظام المتكامل لتصنيف مراحل الأمن الغذائي البحاعة بأها : " فشل على الصعيد الإقليمي في إنتاج أو عرض الأغذية بما يكفي ، مما يؤدي لإحداث زيادة ملحوظة في المرض، والوفيات بسبب النقص الشديد في التغذية ؛ مما يحتم التدخل في الحالات الطارئة، وعادة على مستوى دولي " (r^) 
مما سبق يمكن تعريف زمن المجاعة بأنه زمن ينقص فيه الغذاء نقصًا شديدًا يصعب معه

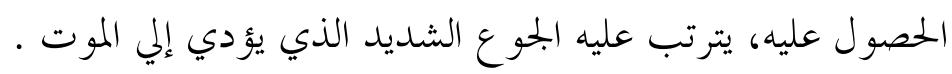

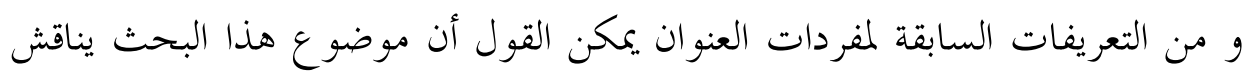

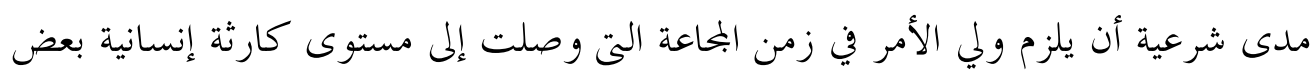

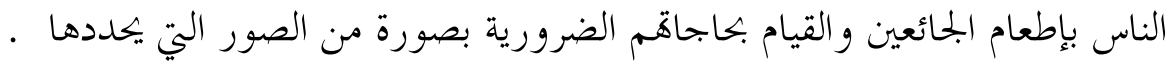
المبحث الثالي : أسباب المجاعة ، و الآثار المترتبة علي المحاعة ، وتصوير لزمن لمن البحاعة وأثر

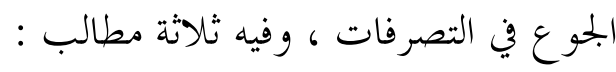
المطلب الأول : أسباب الجاعة

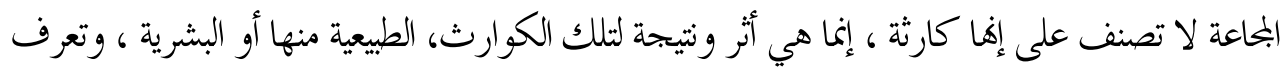
الكارثة بأها : حالة مفجعة يتأثر من جرائها نمط الحياة اليومية فجأة، ويصبح الناس بدون مساعدة، ويعانون من ويلالها، ويصيرون في حاجة إلى حماية ، وملابس، وملجأ ، وعناية طبية، واجتماعية، واحتياجات بهات

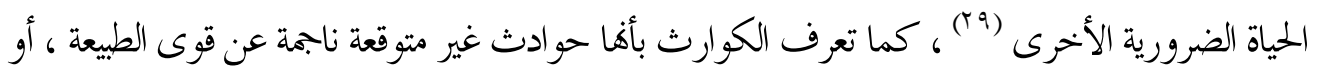

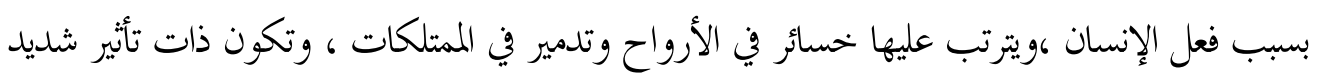
على الاقتصاد الوطني والحياة الاجتماعية ، وتفوق إمكانيات مواجهتها قدرة الموارد الوطنية، وتتطلب مساعدة دولية(·) وهذه الكوارث منها ما يكون بسبب عوامل طبيعية لا دخل للإنسان فيه ، ومنها ما يكون بسبب عوامل من كسب الإنسان نفسه ، وعلى ذلك يمكن تصنيف أسباب متعددة وتقسيمها إلي نوعين :

- النوع الأول : أسباب طبيعية تعود للطبيعة كالزلازل، و الجفاف، والأعاصير، والفيضانات، وفشل المحاصيل الزراعية، أو تفشي أمراض النباتات، وانتشار الأوبئة

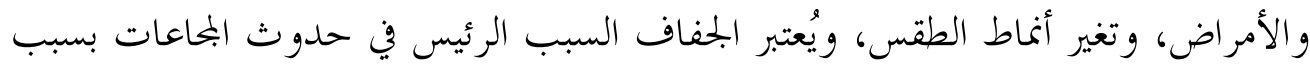

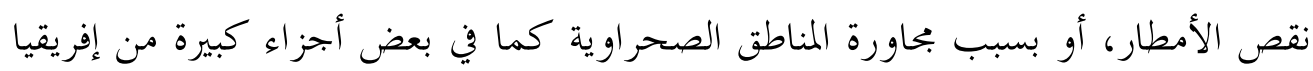

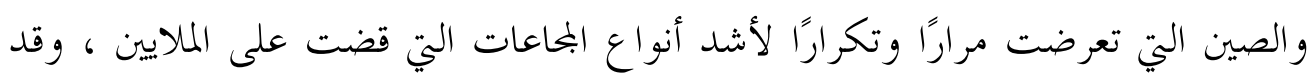

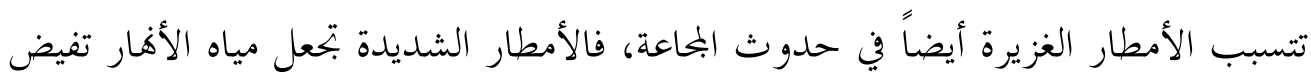


على شواطئها ، وتدمر الأراضي الزراعية، وتفسد المحاصيل بسبب هذا الماء الفائض عن

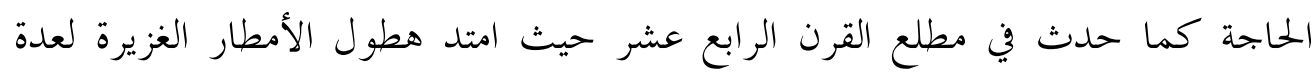

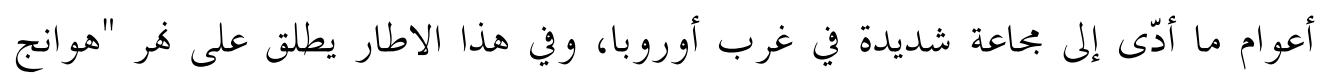

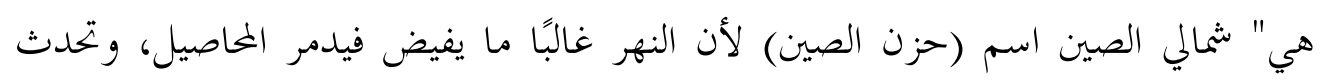

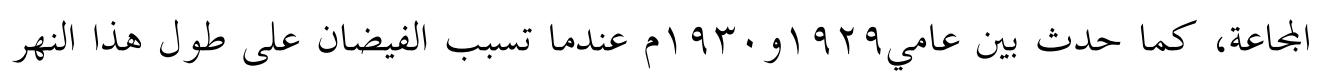

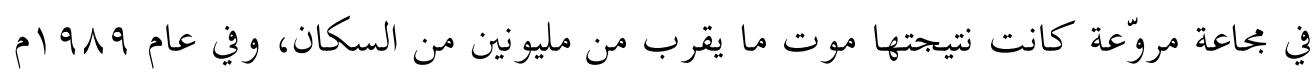

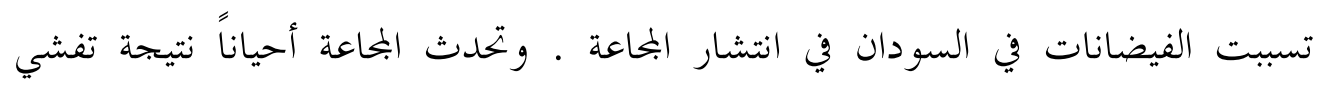

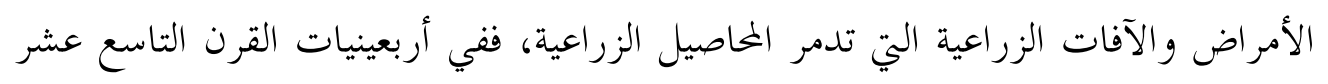

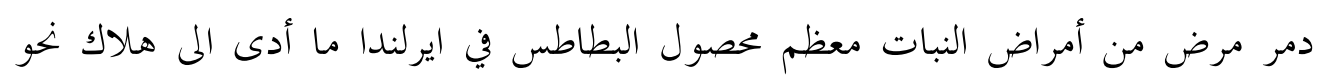

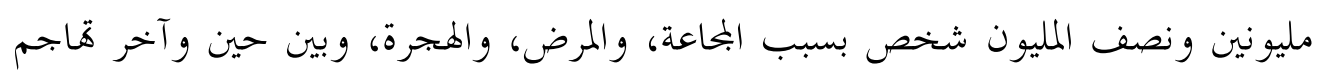

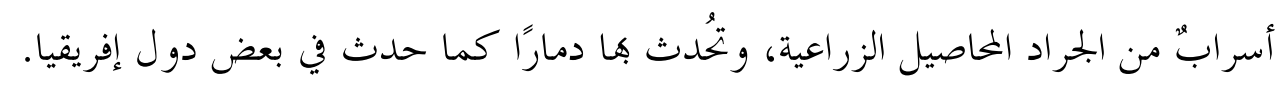

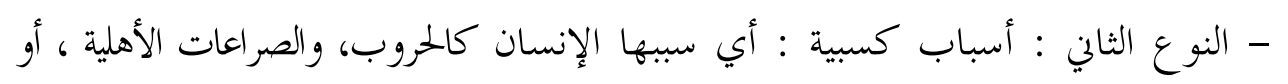

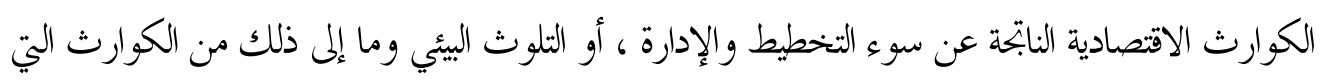

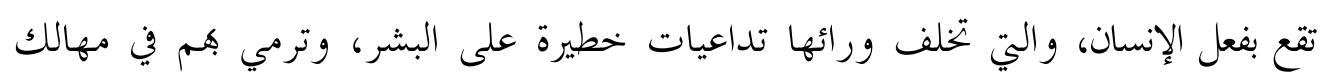
الجوع، والعطش، ونقص الغذاء، وأسباب الحياة .

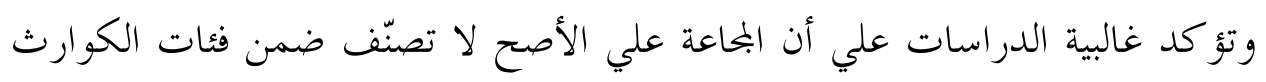

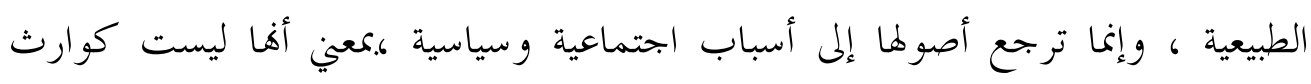

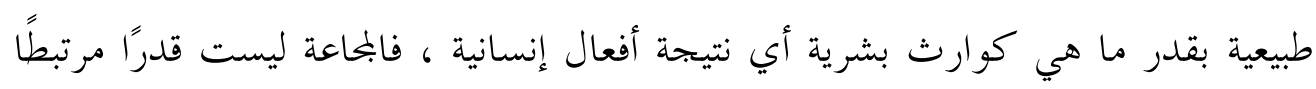

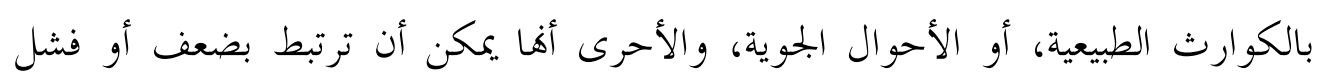

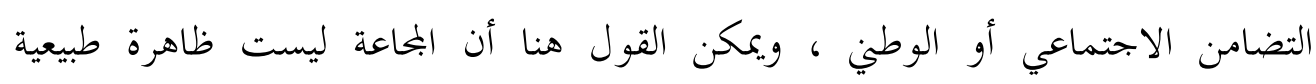

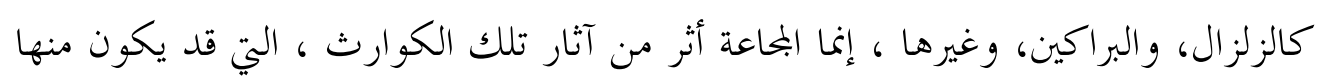

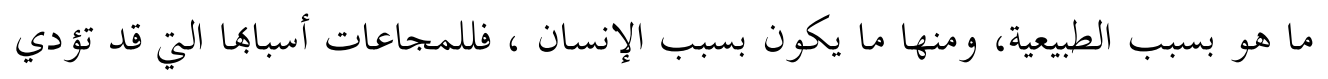

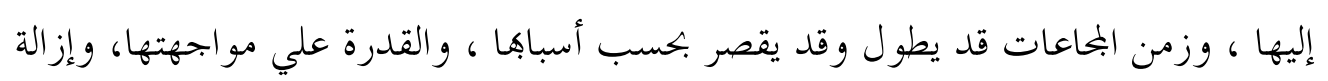

هذه الأسباب (1) 
و "تعتبر البحاعة جزئيا، ظاهرة اجتماعية تشارك في أحداثها الأسواق، وأسعار الغذاء، والتركيبة الاجتماعية. ومنذ عام ع . . ب تبنتّ منظمات مهتمة بإغاثة البحاعات مثل:

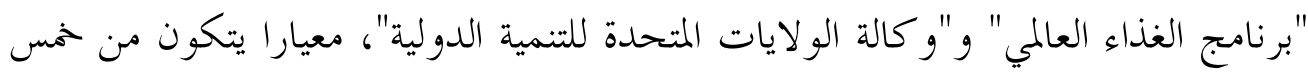
درجات لتحديد حجم المجاعة وكثافتها، مستخدمين عناصر مقومات المعيشة، وعدد الوفيات، وسوء تغذية الأطفال كمؤشرات لتوصيف درجات المعيار، وهي : انعدام الأمن الغذائي، وأزمة غذاء، وبحاعة، وبحاعة حادة، وأخيرا بجاعة قصوى أو كارثية ـ أما الأمم

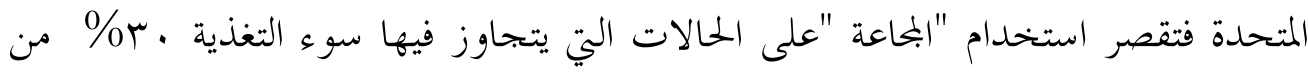

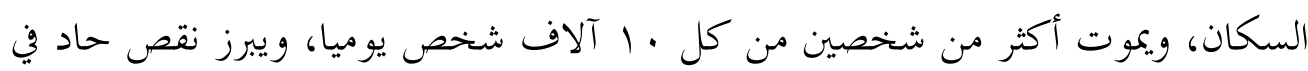
الحصول على الغذاء من جانب نسب عالية من السكان . ويعد الجوع ونقص الغذاء وما يترتب عليهما من الفقر، وسوء التغذية، والأمراض، ومن ثم الموت من أهم التحديات والمشكلات الاقتصادية التي تواجه العالم المعاصر ، وقد أطلق عليه بعضهم " طاعون العصر

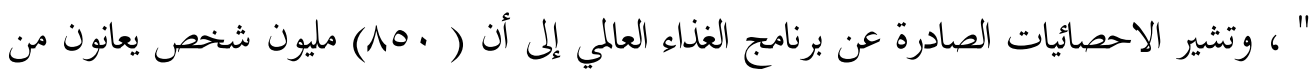

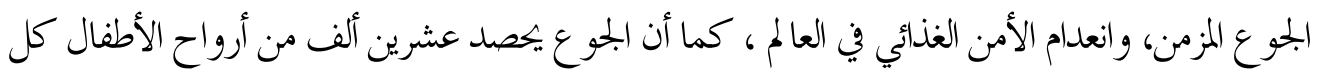
يوم بسبب الجفاف، وقلة الأمطار، والكوارث الطبيعية المتكررة ،والفيضانات المدمرة، والزلازل، وأحوال المناخ القاسية ، إضافة إلى القلاقل، والحروب الدولية والإقليمية ، و كذلك الصراع القبلي والحروب الأهلية في كنير من دول العالم ، الأمر الذي أدي إلى نزوح الملايين من قراهم ومدفم تاركين أرضهم بلا زراعة،

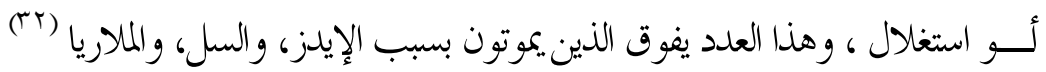

المطلب الثاني : آثار البجاعــــــة

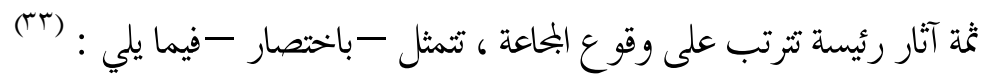

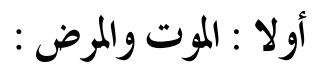
كلاهما من الآثار الرئيسية والمباشرة للمجاعة، فالأفراد الذين ينقصهم الطعام الكافي يفقدون وزفمب،

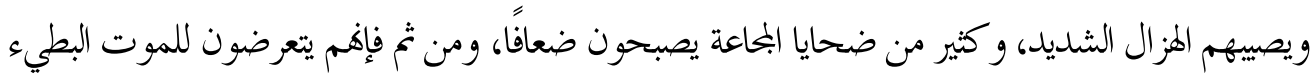

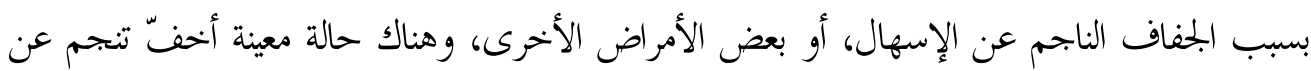

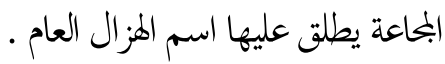


و أول من يلقون حتفهم بسبب الجحاعة هم في العادة المرضى من كبار السن ، كذلك الأطفال الذين

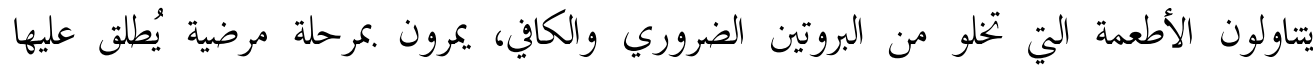

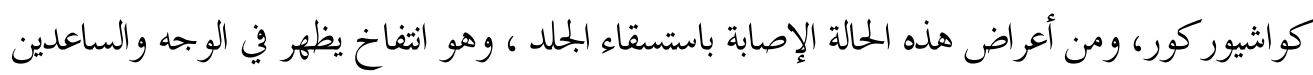

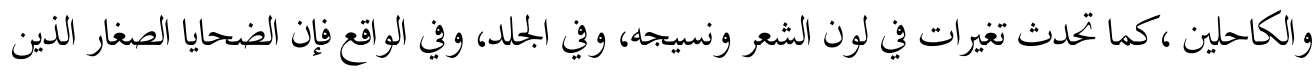

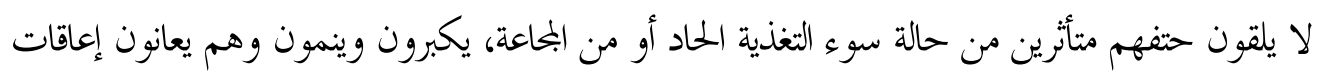

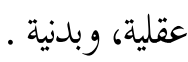

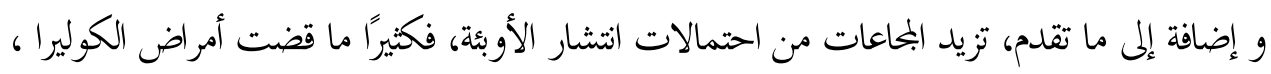

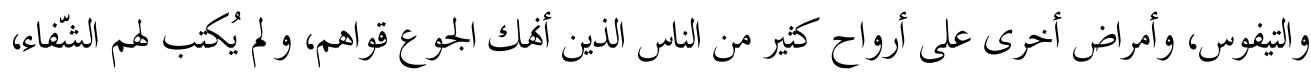

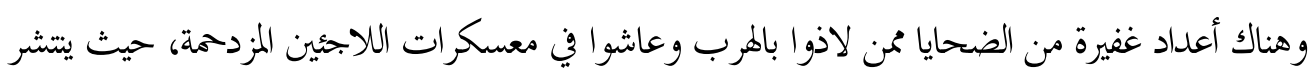

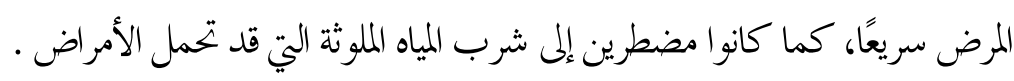

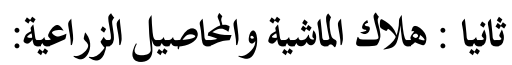

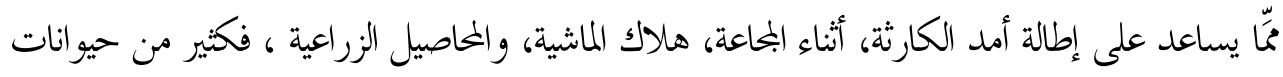

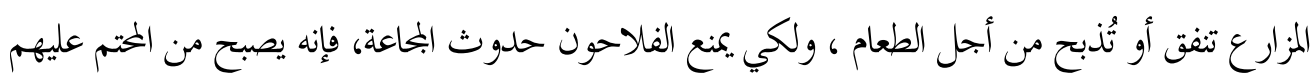

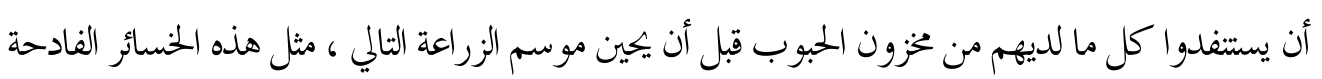

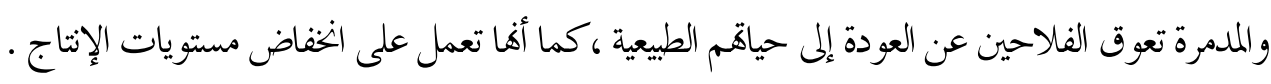
ثالثًا : الجريمة والاضطرابات الاجتماعية:

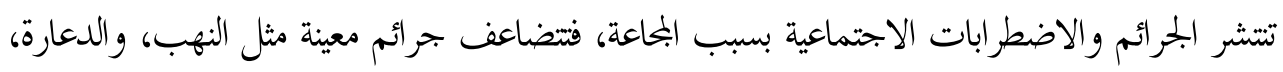

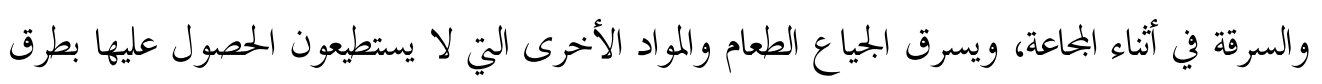

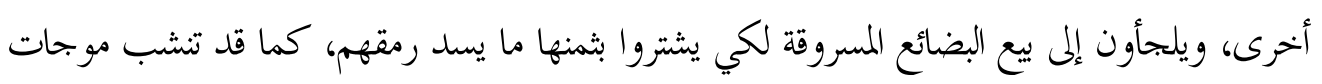

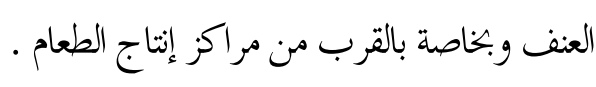
رابعًا : المجرة والزورح بعيدًا عن مناطق البجاعة :

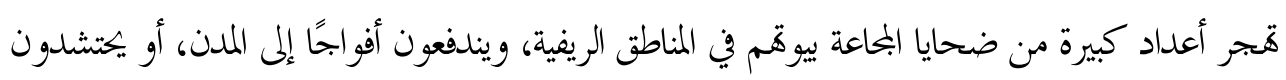

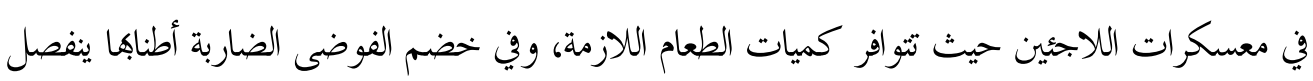

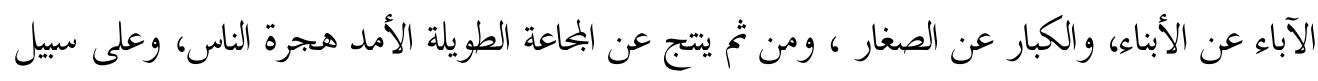


المثال، البحاعة التي حدثت بسبب تدهور محصول البطاطس في إيرلندا والتي أرغمت نحو مليونين من السكان على الهجرة إلى أقطار أخرى، وبخاصة الولايات المتحدة الأمريكية .

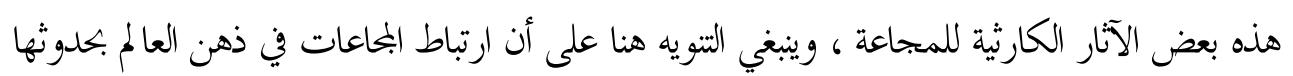
في قارة أفريقيا ، حيث يتتشر الفقر، ويسود الجفاف ، وهيمن الصراعات السياسية في معظم دولها ، ارتباط

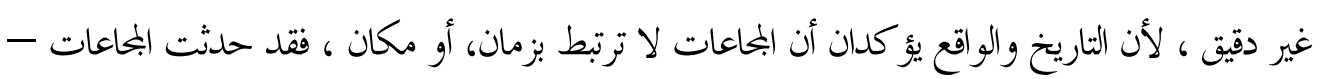

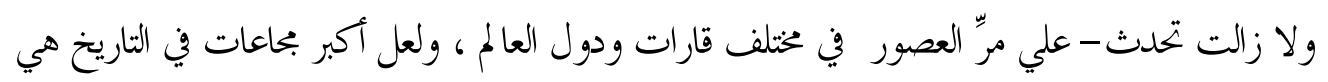

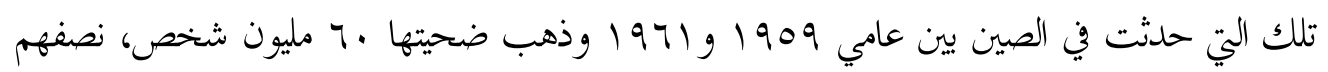

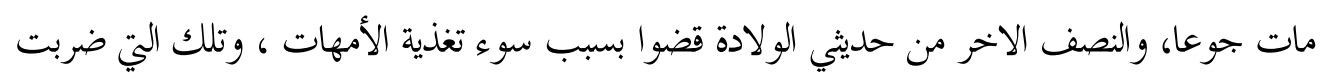

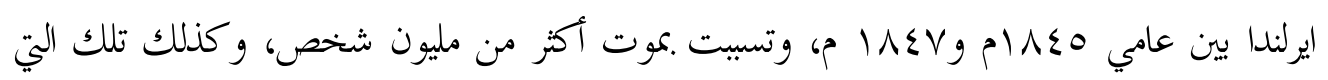

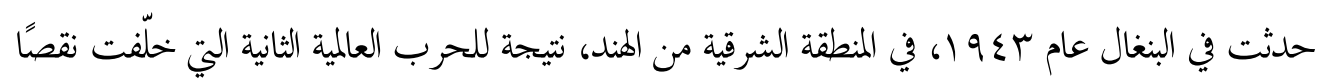
عامًا في الطعام، وأدت إلى قطع إمدادات الأرز من بورما التي كانت تحتلها حينذاك اليابان، وأدت المى وفاة نحو مليولي إنسان جوعًا. وفي عصرنا الحالي قدد المحاعة ملايين البشر في أفريقيا الجنوبية، والقرن الأفريقي حيث يقف الجفاف إنفال

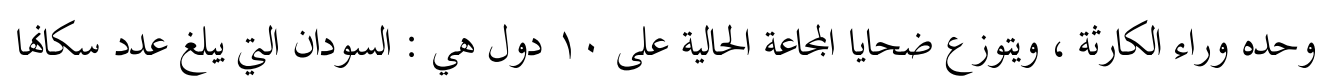

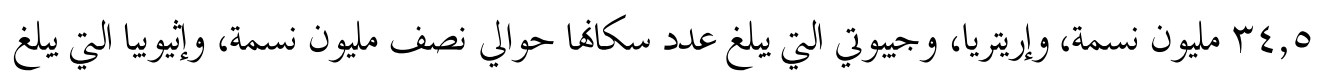

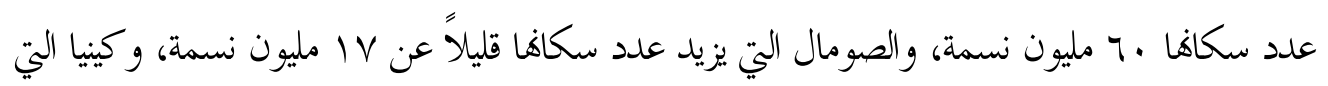

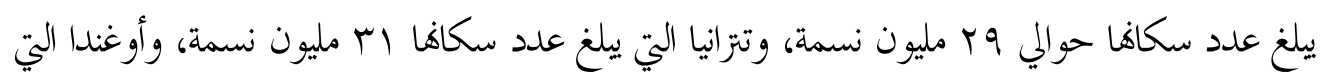

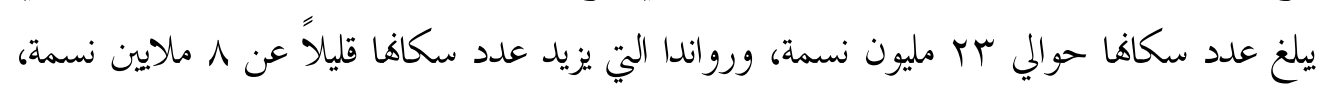
وبوروندي التي ييلغ عدد سكاها V, ه ملايين نسمة .

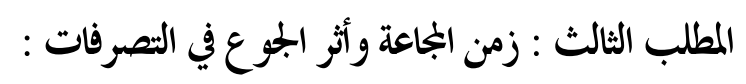
للوقوف على طبيعة زمن البحاعة وتصور أثر الجوع في التصرفات ينبغي الرجوع للتاريخ الإسلامي

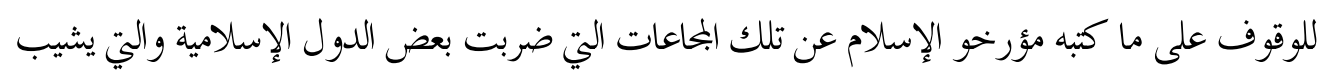

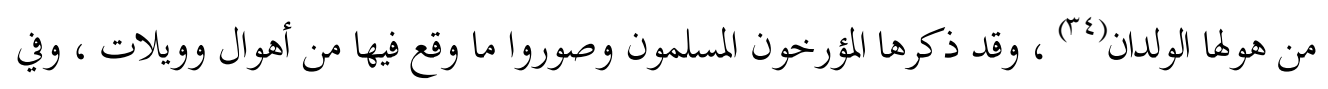
هذا المطلب تناول مختصر لما يترتب علي المحاعات من مآسٍ وويلات من خلال بعض ما كنبه 
المؤرخون المسلمون من أخبار هذه البحاعات المؤلمة التي ضربت بعض الحواضر الإسلامية، وما صحبها من

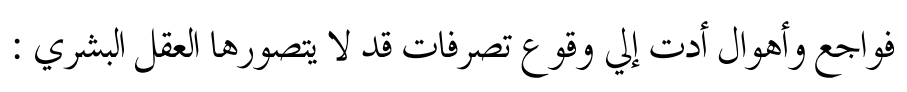

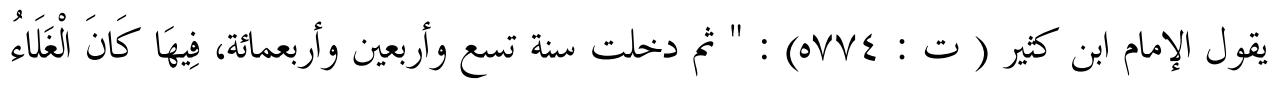

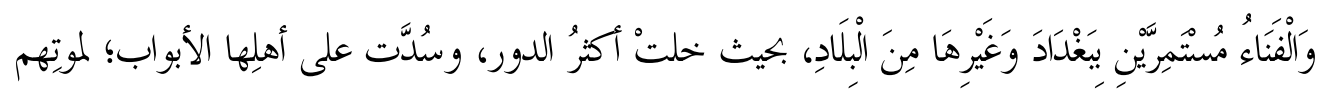

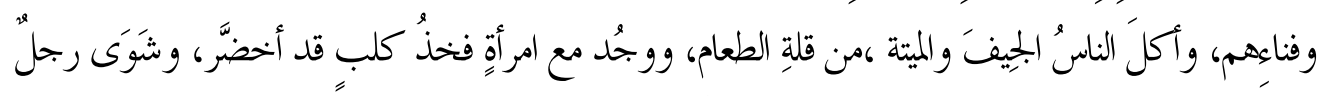

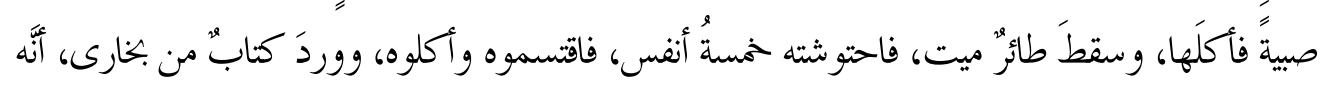

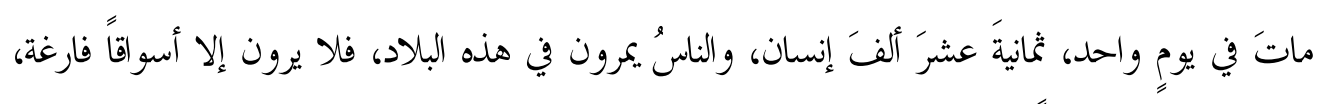

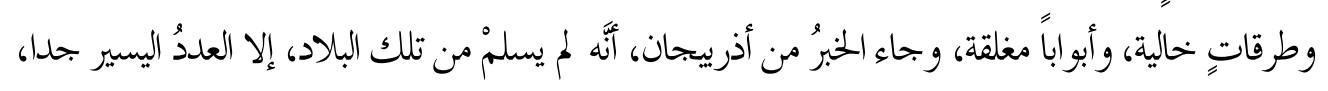

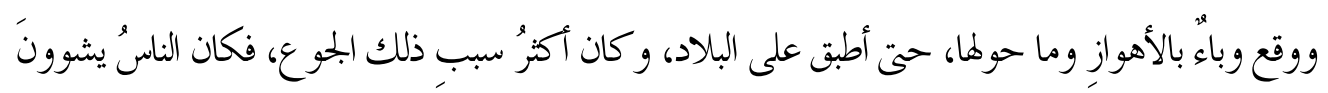

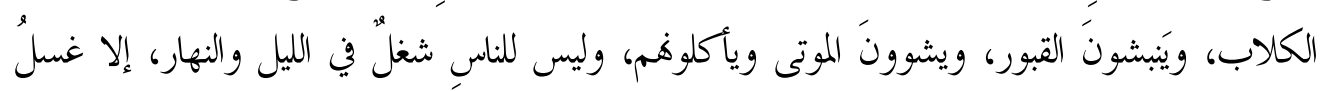

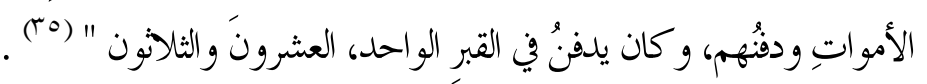

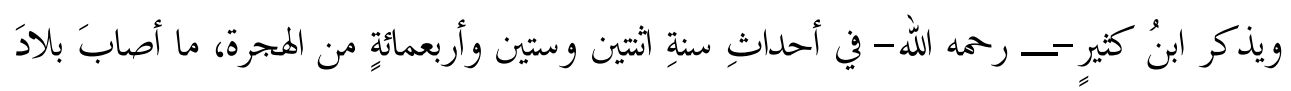

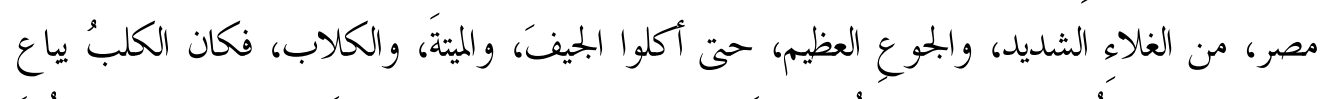

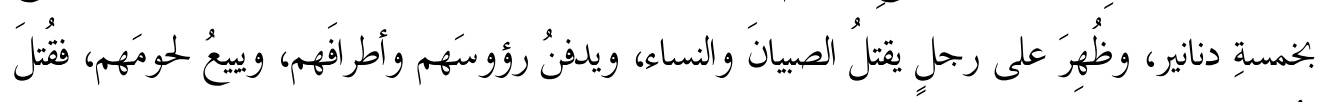

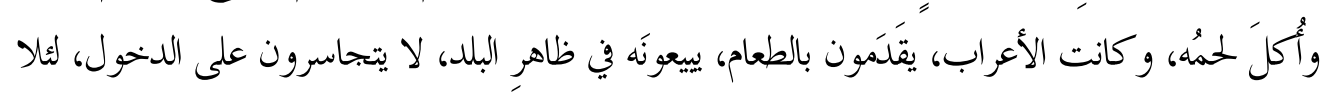

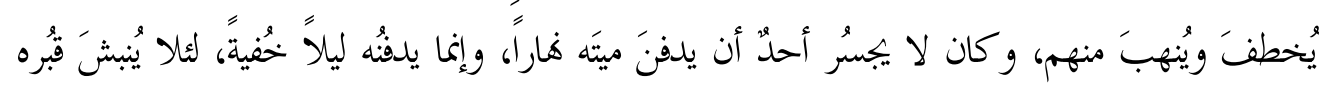

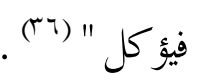
ويذكر المقريزي ( ت : ع عهه ) أخبار الشدة المستصرية، أو الشدة الكبرى كما تسمى، والتي وقعت

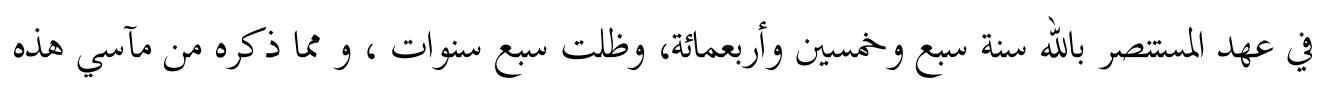

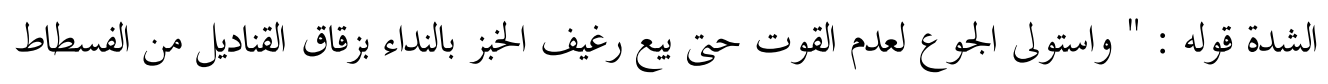

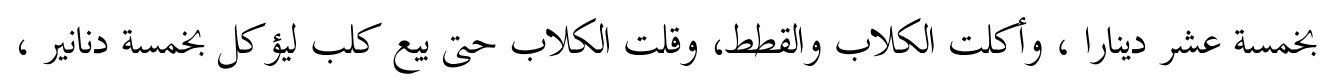

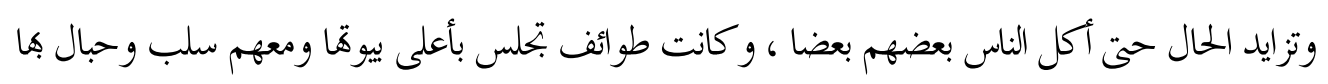

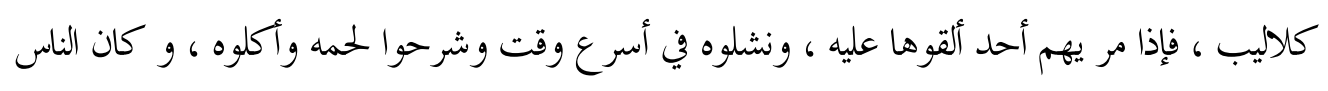

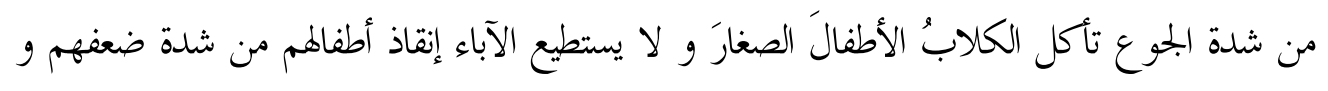


هزهم، و أكل جماعه من الناس حمار الوالي، و شنقت هذه الجماعة، وعند الصباح وجلدوا أن الجماعة المشنوقة قد أكلت من على المشنقة...

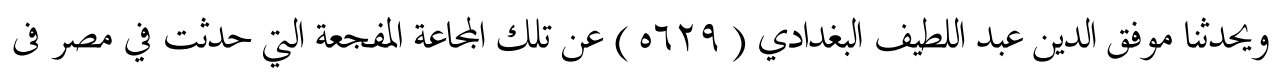

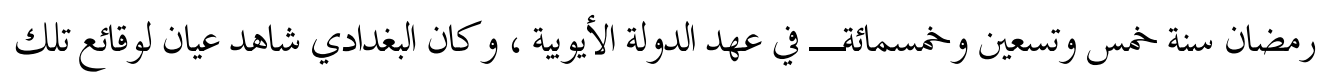

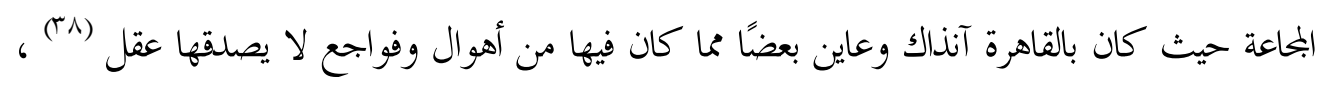

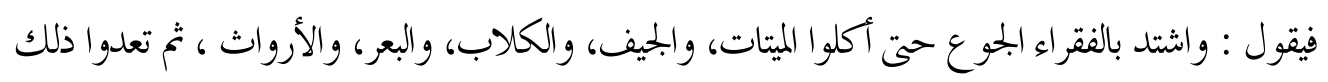

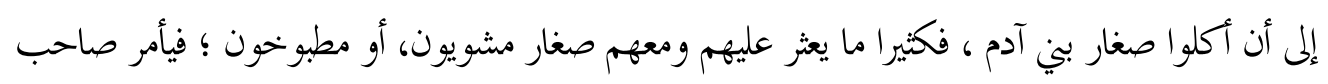

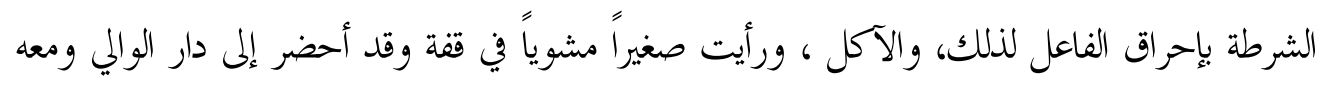

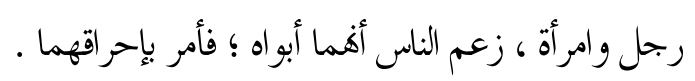

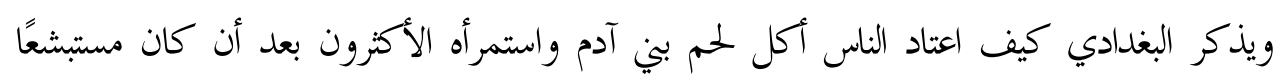

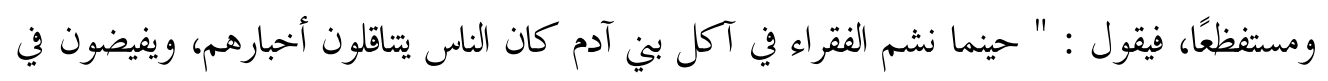

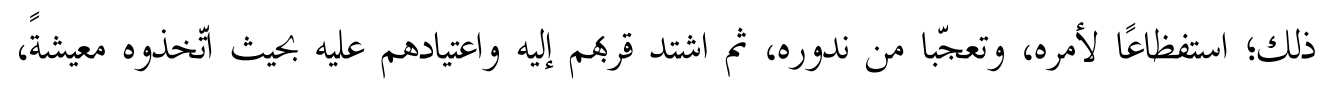

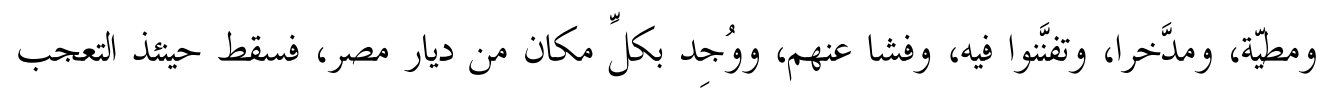

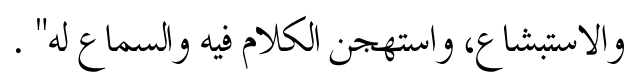

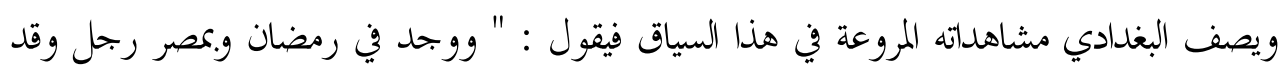

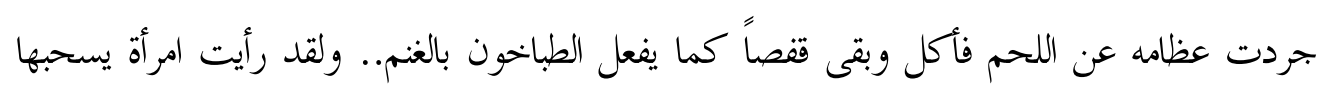

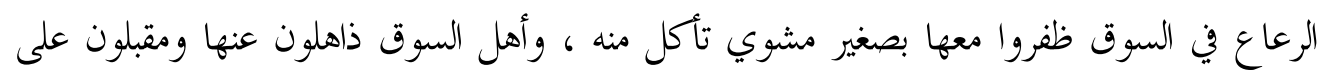

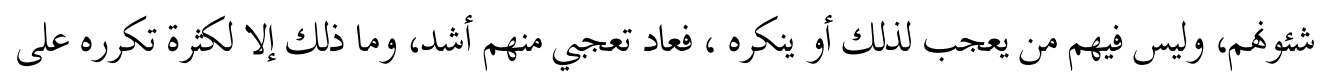

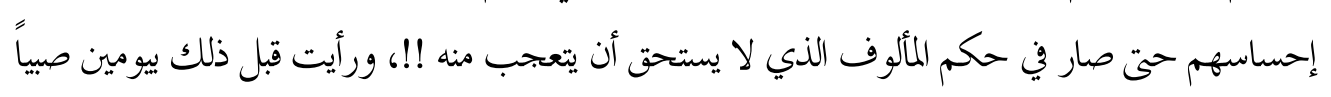

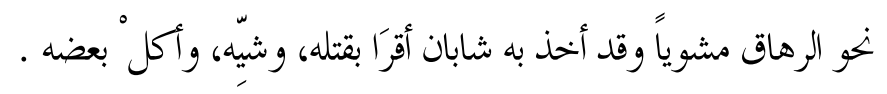

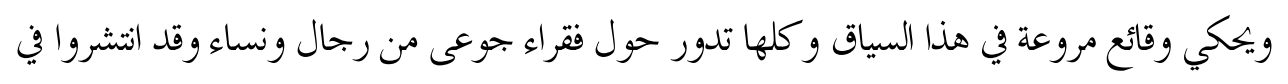

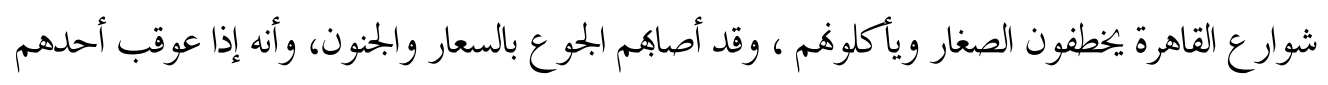

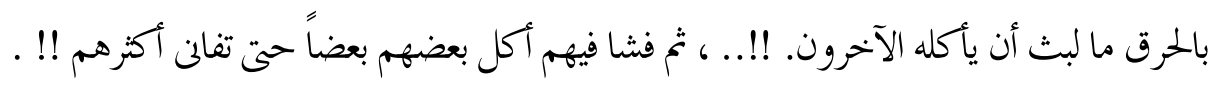


ثم يمكي البغادي عن الحيل التي كان يخترعها بعضهم لإلإيقاع بالناس وأكلهم .. ويقول إن الوالي

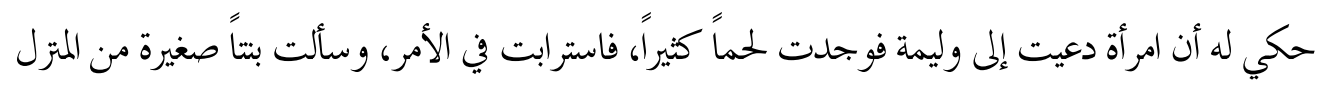

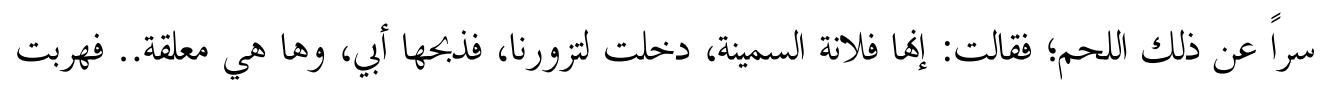

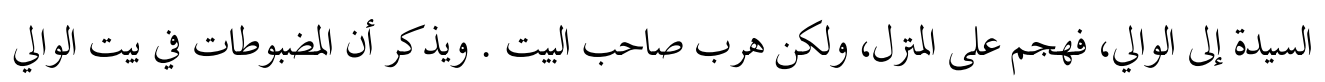

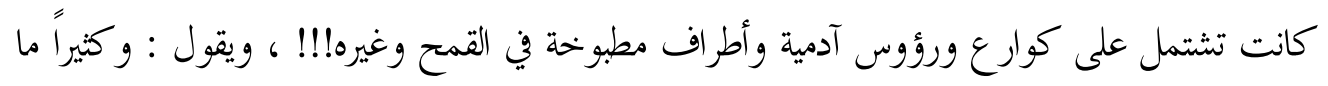

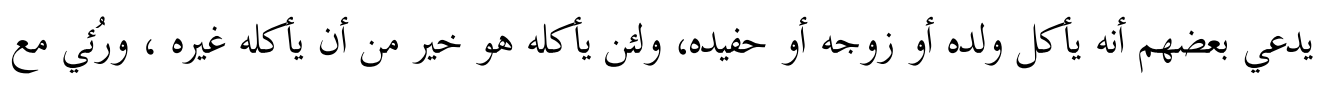

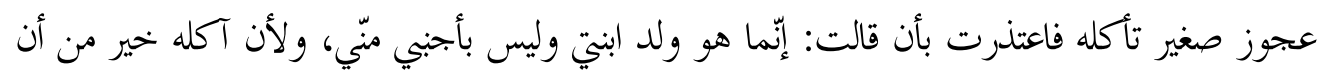

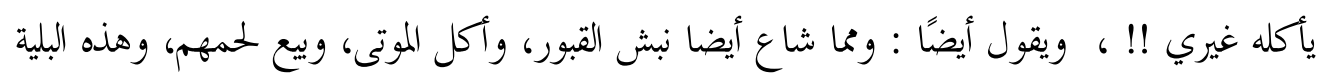

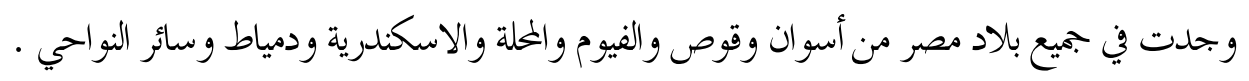

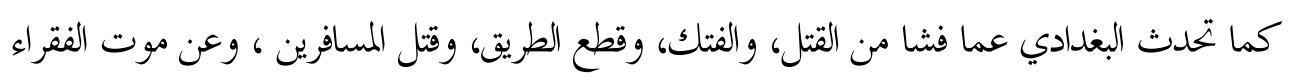

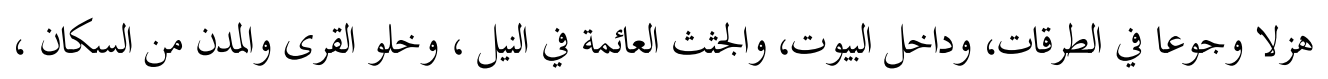

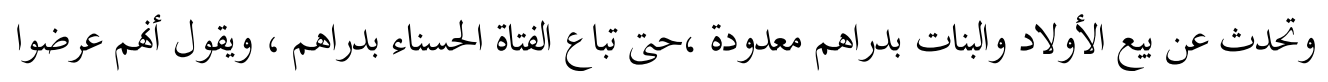

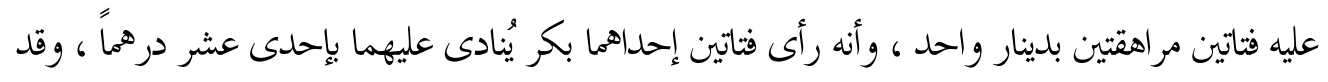

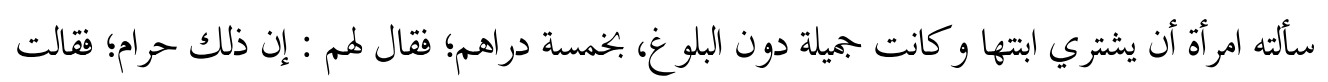

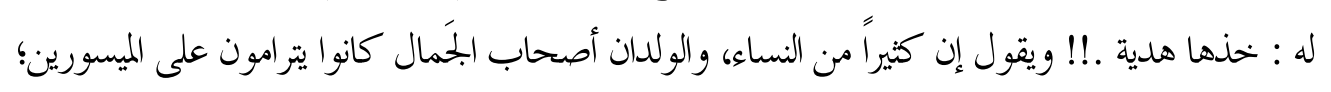

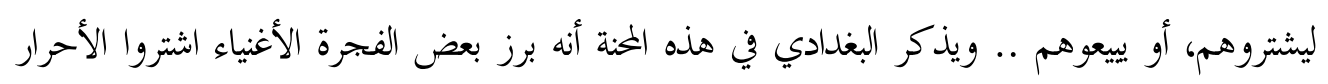

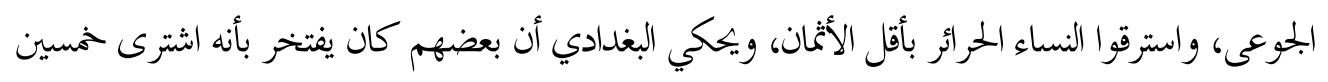

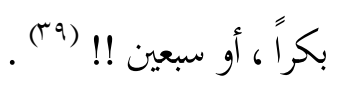

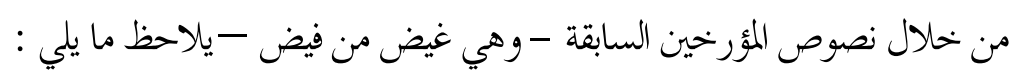

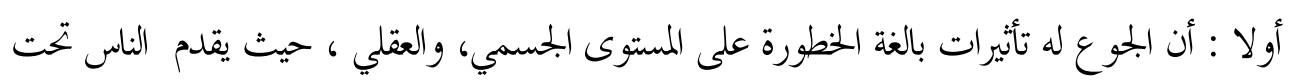

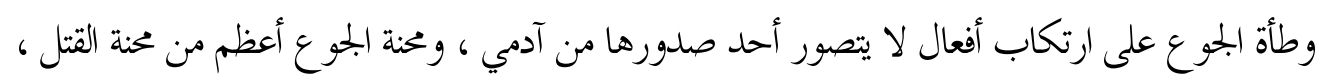

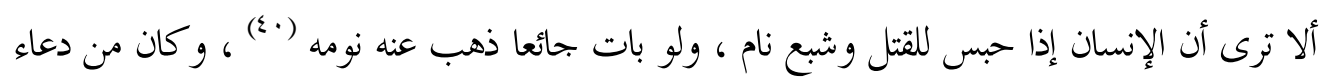

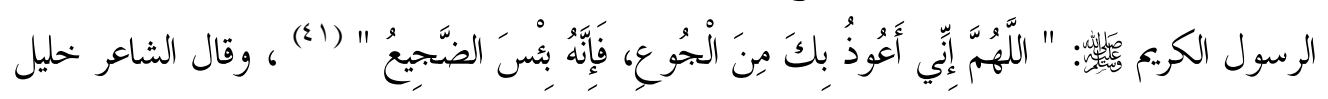
مطران : 
فعل الجوعُ في النفوس فعالا عاد منها الأحرار كالأوغاد

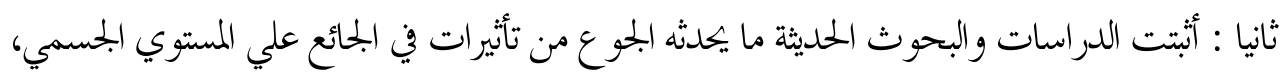
والعقلي ، فللجوع تأثيرات فسيولوجية على الجسم، تبدأ وتزداد شيئا فشيئا إلى أن تلقي بصاحبها في القبر، وهي لا تقتصر على قرصة الجوع التي يشعر هها في بطنه، بل تمتد

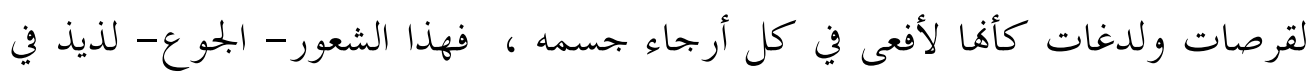

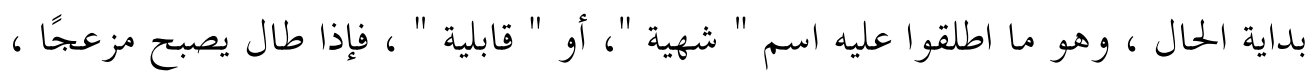

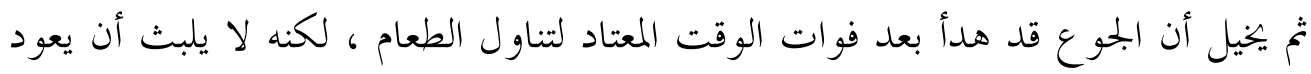

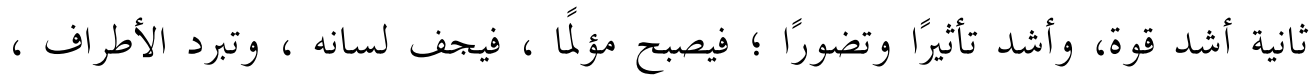
وتتباطؤ حركة القلب ، ويضعف النبض ، ويتمدد الصدر بعناء ، وهبط حرارة الجلد ،

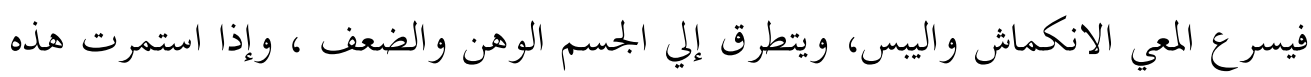

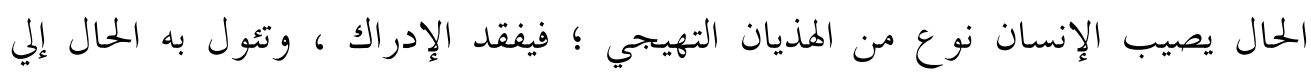

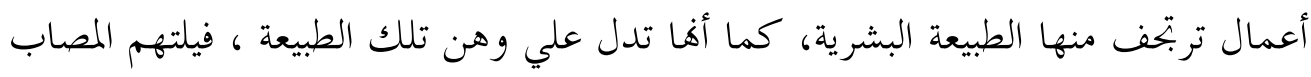

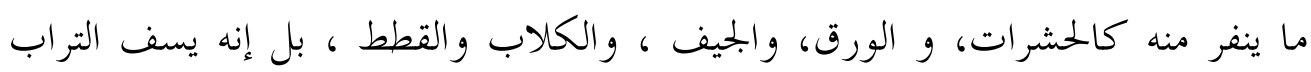

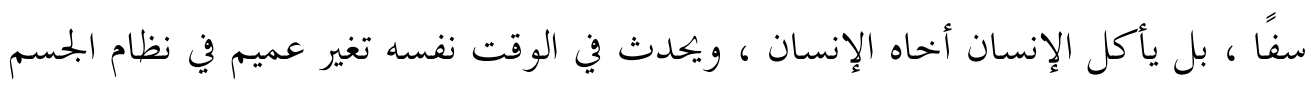

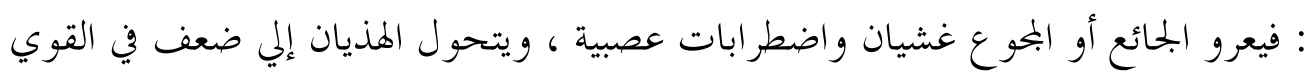

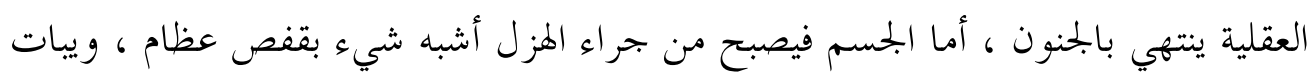

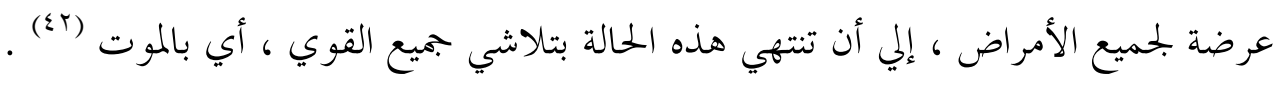

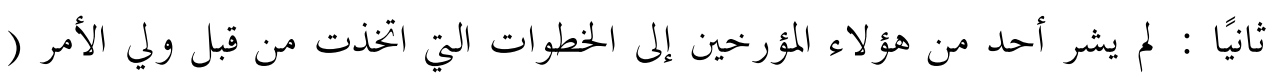

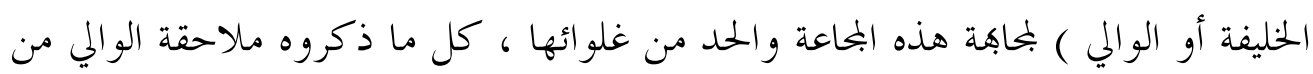

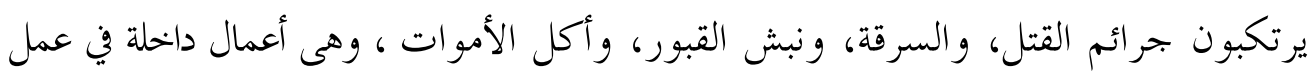

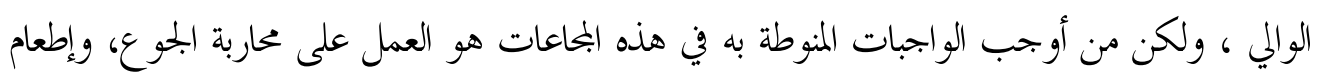
الجائعين وترميقهم ، وإزالة الأسباب التي قادت الناس -ر.بما قسرًا - إلى ارتكاب هذه الأفعال .

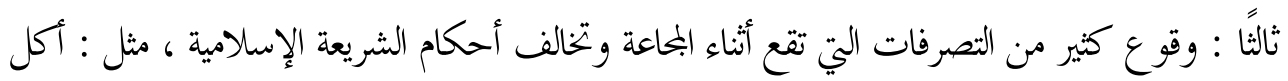

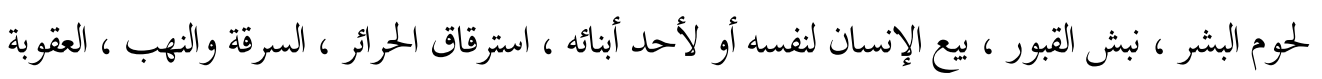




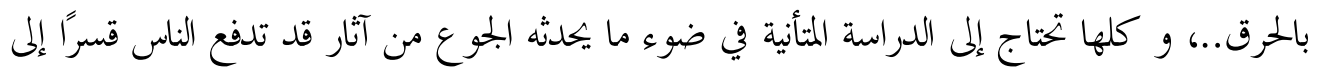

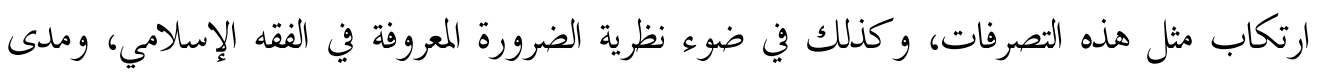
اعتبارها في مثل هذه الظروف .

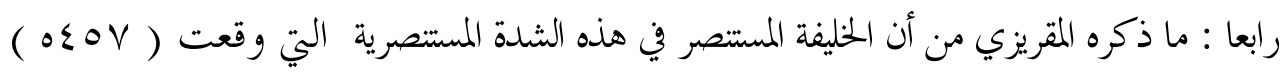

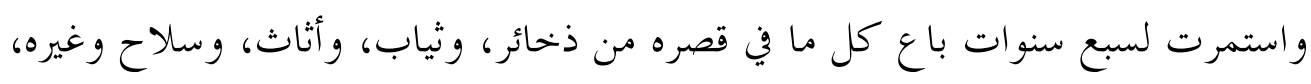

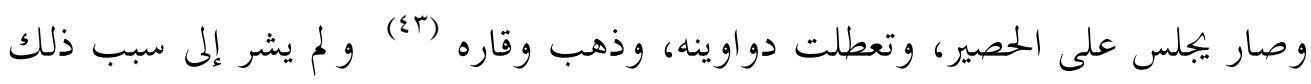

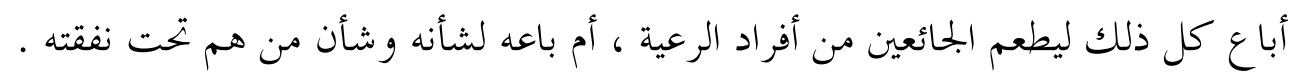

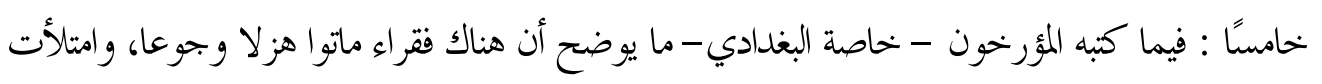

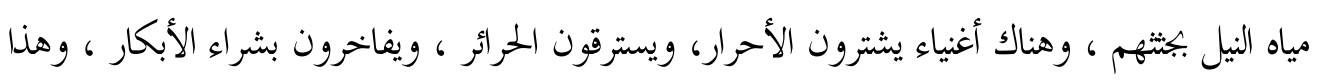

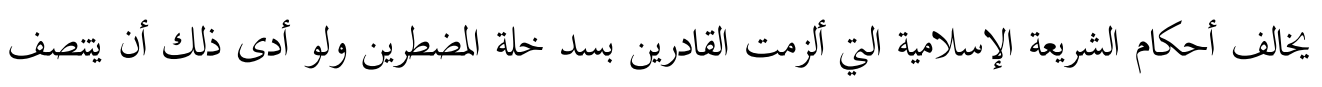

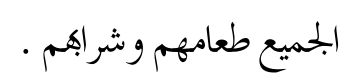
سادسًا : وضعت الشريعة الإسلامية للمجاعة حلولا ناجعة ، منها أها أوجبت على القادئ لهارين إطعام

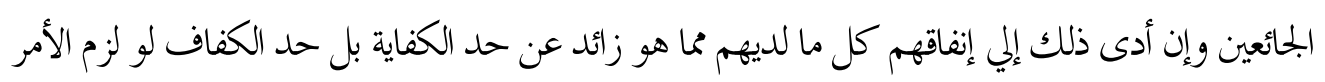

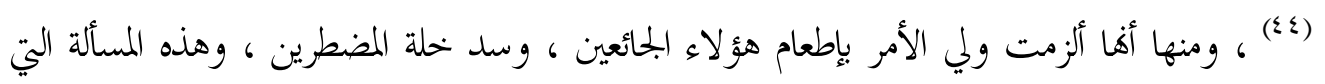
سيفصل البحث القول فيها في المبحث التالي .

\section{المبحث الثالث : مدى سلطة ولي الأمر في فرض الإعاشة :}

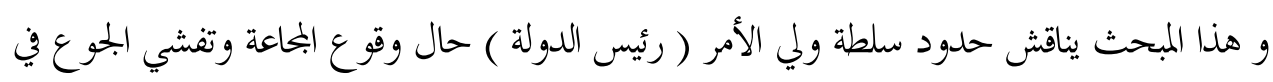

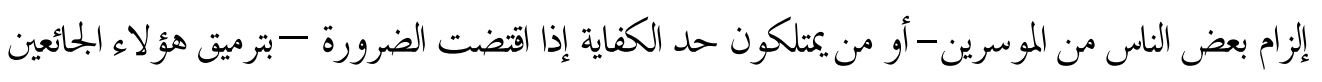

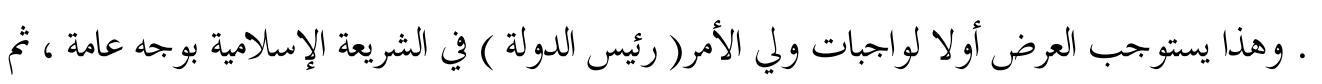

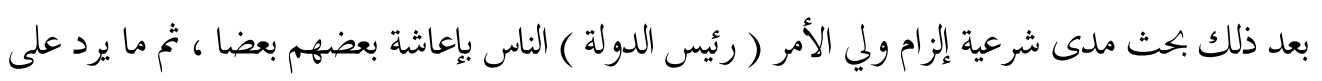

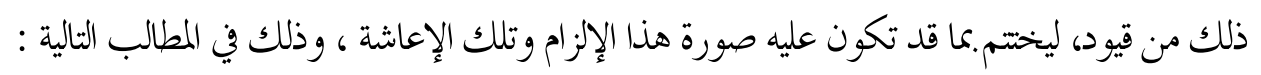




\section{المطلب الأول : واجبات ولي الأمر :}

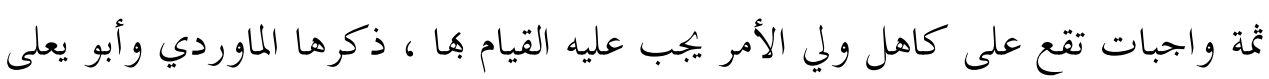

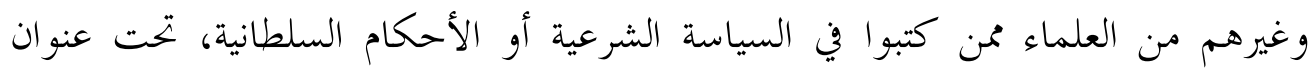

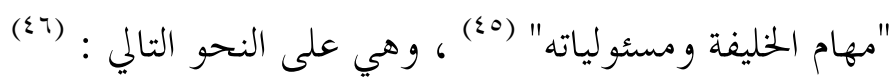
أحدها: حفظ الدين على أصوله المستقرة، وما أجمع عليه سلف الأمة، فإن بخم مبتدع،

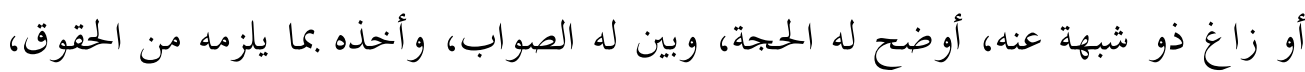

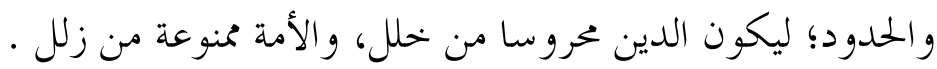
الثاني: تنفيذ الأحكام بين المتشاجرين، وقطع الخصام بين المتنازعين حتى تعم النصفة، فلا يتعدى ظا لم، و لا يضعف مظلوم.

الثالث: حماية البيضة، والذب عن الحريم؛ ليتصرف الناس في المعايش، وينتشروا في الأسفار آمنين من تغرير بنفس، أو مال.

الرابع: إقامة الحدود؛ لتصان محارم الله تعالى عن الانتهاك، وتحفظ حقوق عباده من إتلاف، واستهلاك.

الخامس: تحصين الثغور بالعدة المانعة، والقوة الدافعة حتى لا تظفر الأعداء بغرة ينتهكون فيها محرما، أو يسفكون فيها لمسلم أو معاهد دما. السادس: جهاد من عاند الإسلام بعد الدعوة حتى يسلم أو يدخل في الذمة؛ ليقام بحق الله- تعالى - في إظهاره على الدين كله . السابع: جباية الفيء، والصدقات على ما أوجبه الشرع نصا واجتهادا من غير خوف الف لهن ولا عسف.

الثامن: تقدير العطايا وما يستحق في بيت المال من غير سرف ولا تقتير، ودفعه في وقت لا تقديم فيه و لا تأخير.

التاسع: استكفاء الأمناء، وتقليد النصحاء فيما يفوض إليهم من الأعمال، ويكله إليهم

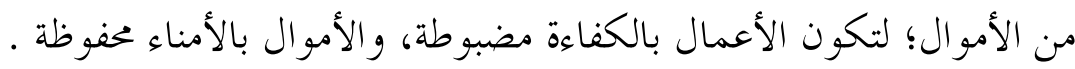


العاشر: أن يباشر بنفسه مشارفة الأمور، وتصفح الأحوال؛ لينهض بسياسة الأمة،

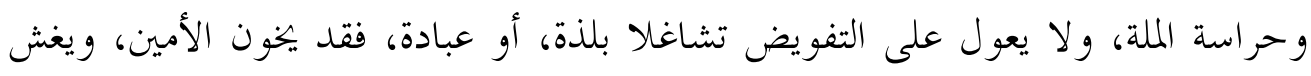

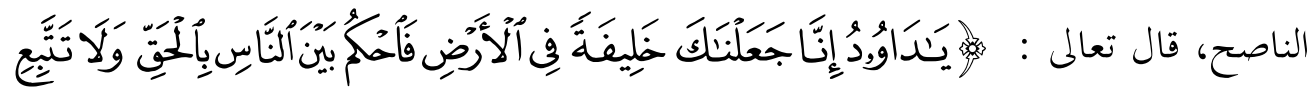

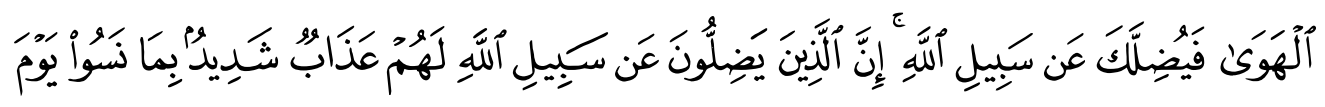

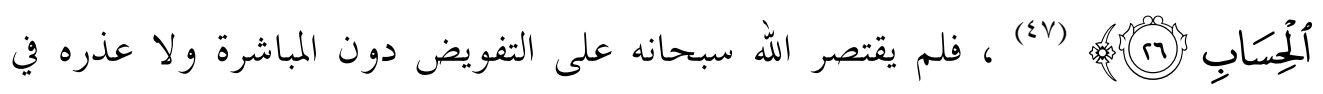

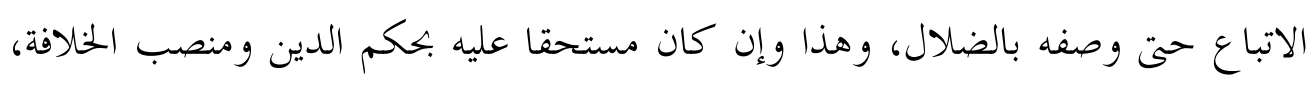

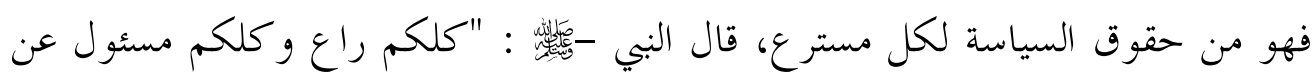
رعيته" .

و واضح مما سبق أن من واجبات ولي الأمر ( رئيس الدولة) ومسئولياته جباية الأموال

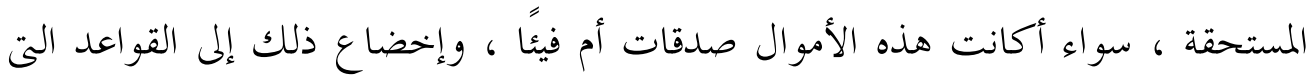

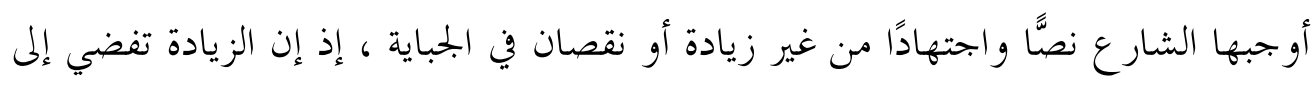

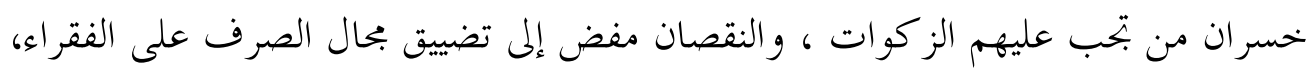

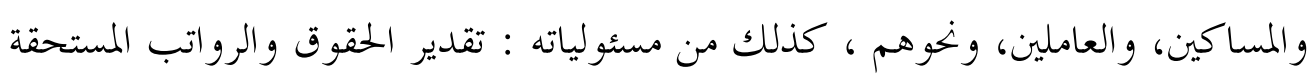

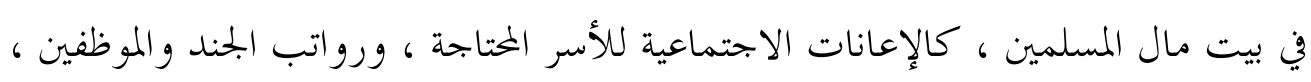

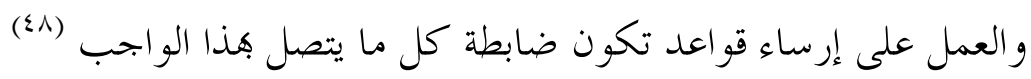

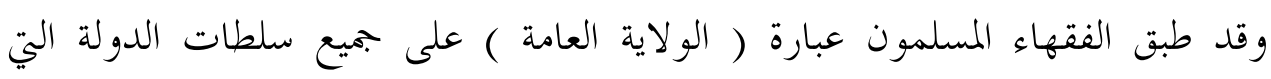

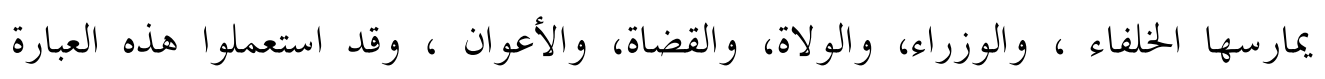

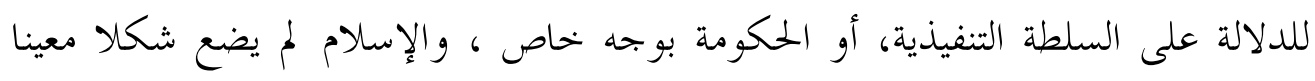

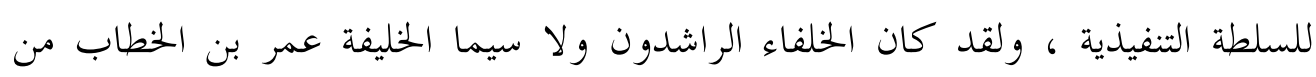

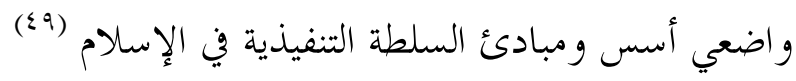

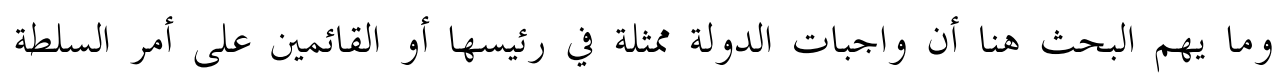

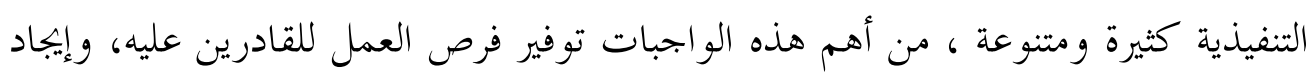

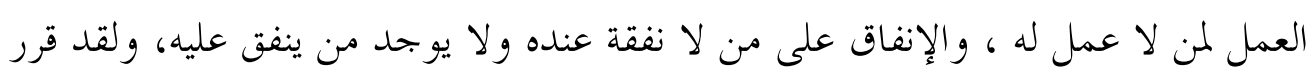


فقهاء المسلمين في هذا السياق أن من ليس له قريب غني ، وهو فقير عاجز ، فإن نفقته على

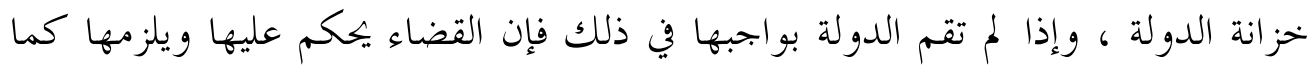

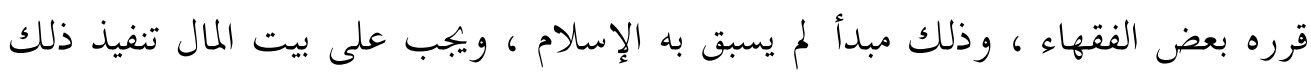

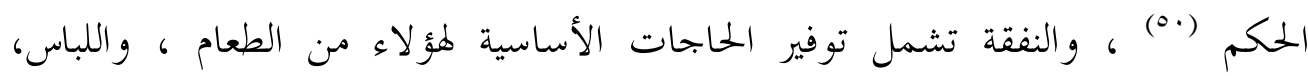

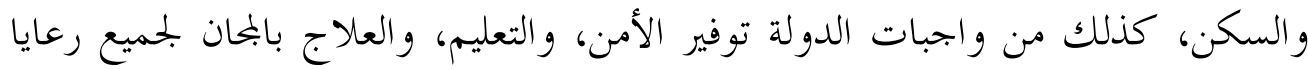

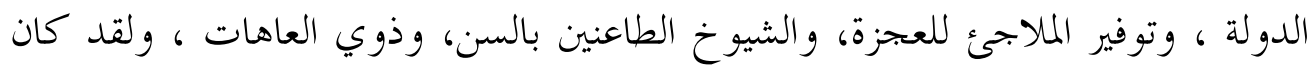

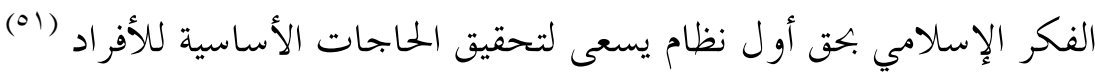

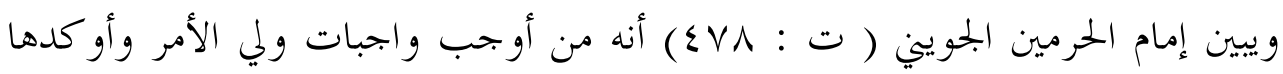

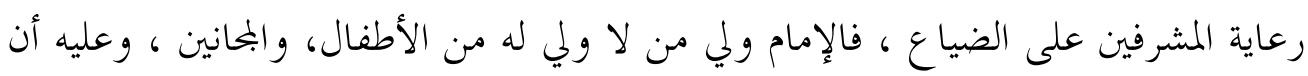

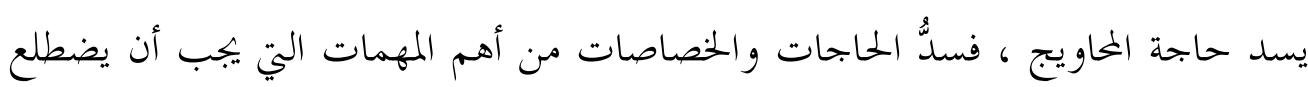

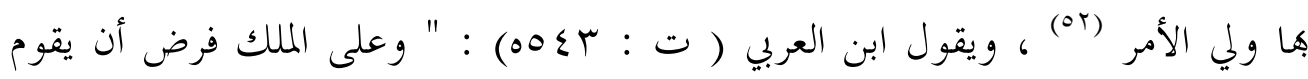

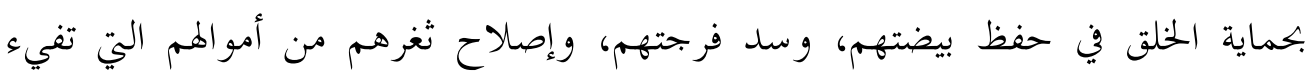
عليهم، وحقوقهم التي يجمعها خزنتهم تحت يده ونظره، حتى لو أكلتها الحقوق، وأنفدها

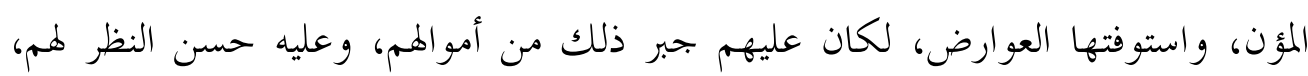

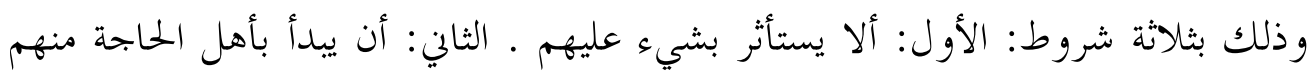

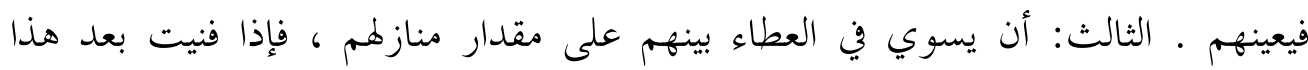

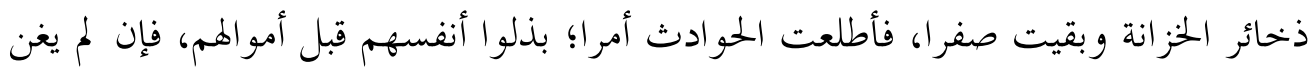

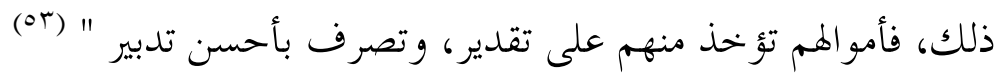

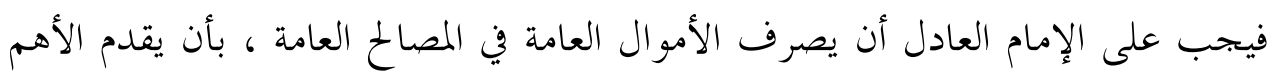

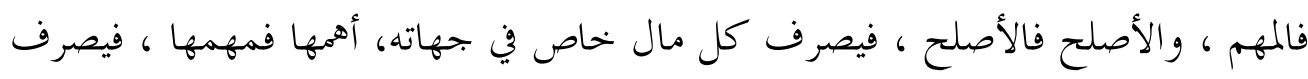

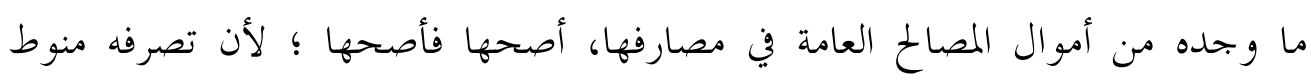

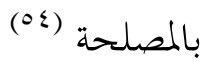




\section{المطلب الثاني : سلطته في فرض الإعاشة :}

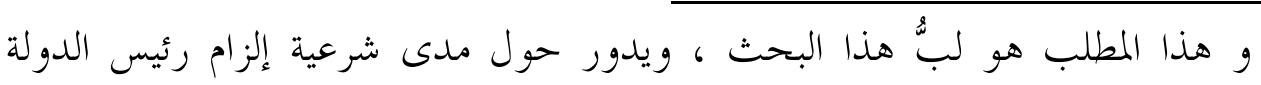

القادرين بإطعام الجائعين مدة وقوع المحاعة .

ولعله من نافلة القول هنا إن إجراء فرض الإعاشة اجراء طارئ لمواجهة تبعات كارثة

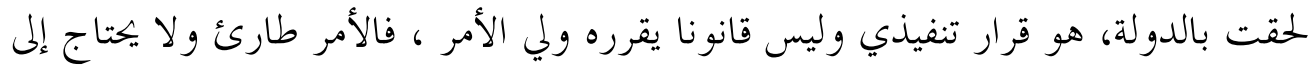

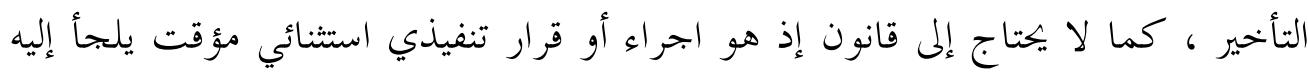
رئيس الدولة في مواجهة ظرف استثنائي طارئ لا يلبث إلا أن ينتهي بانتهاء هذا الظرف الاستثنائي الطارئ ، هذا القرار التنفيذي ينطلق من واجبات ولي الأمر والتي منها القيام

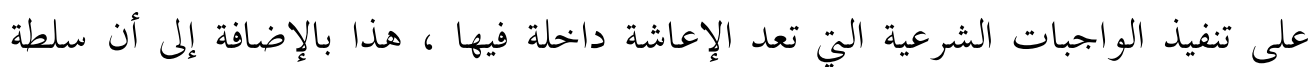
رئيس الدولة في التشريعات المعاصرة لا تعطه حق إصدار القوانين، إنما من حقه اقتراح القوانين وتقديمها للمجالس المختصة (00)

كذلك تحدر الإشارة إلى أن ولي الأمر تتجاذبه سلطتان هما : السلطة المقيدة : وتعني

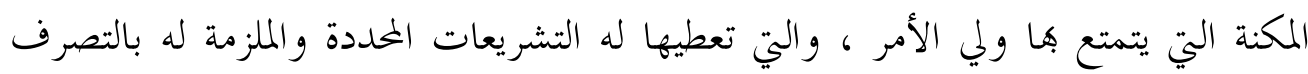

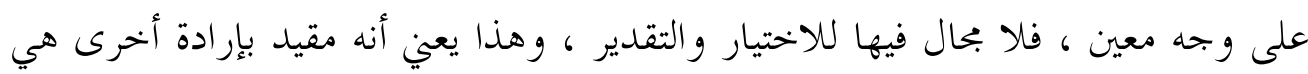

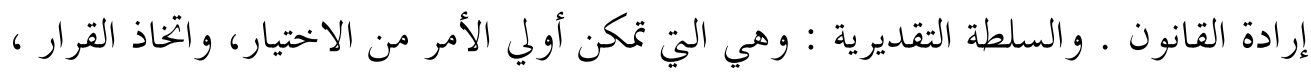

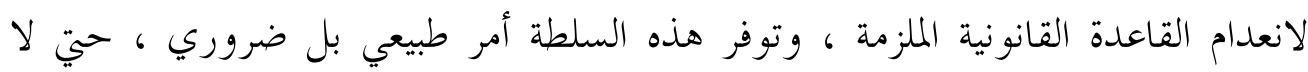

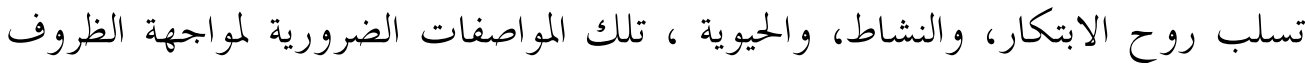

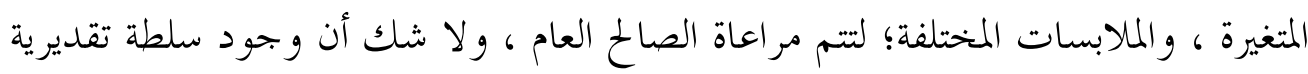

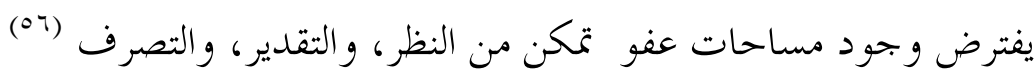

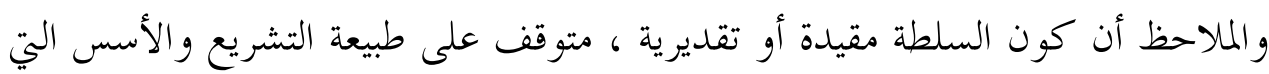
يقوم عليها ، فإذا كان التشريع يميل إلى التفصيل والتدقيق ، فإن بحال التقدير يتقلص وتكون السلطة وقتها مقيدة ، أما إذا كان التشريع يميل إلى التأصيل ، فيورد أحكاما في

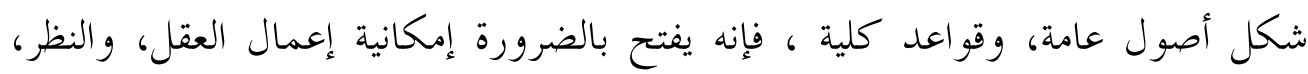

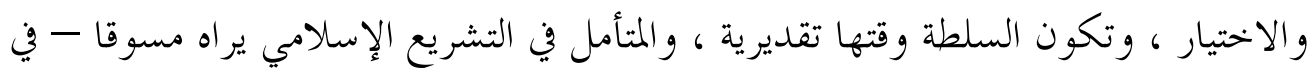


أغلب القضايا - في هيئة نصوص عامة ، مما يسمح لولي الأمر بإعمال العقل، والقيام

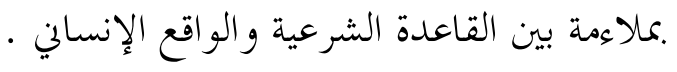

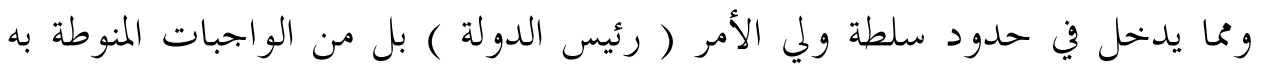

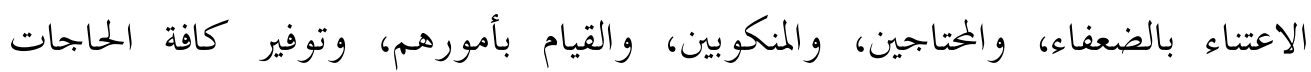

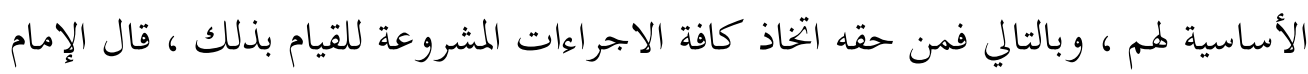

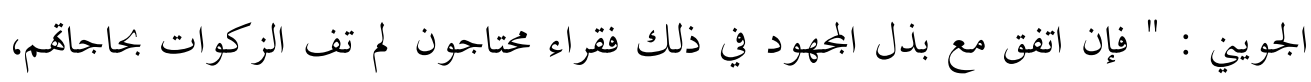

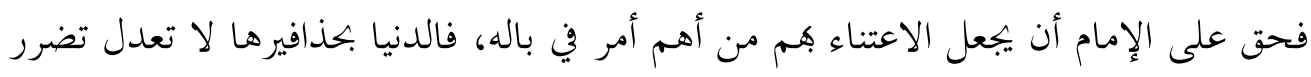

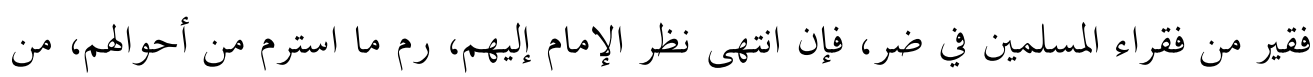

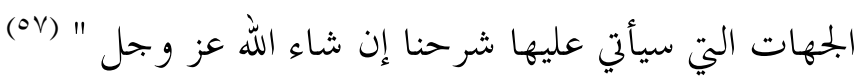

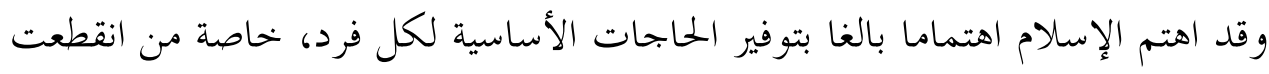

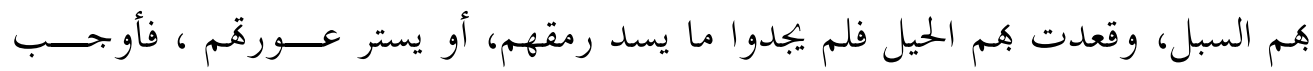

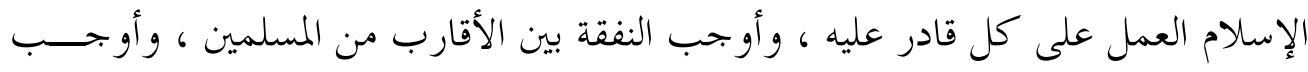

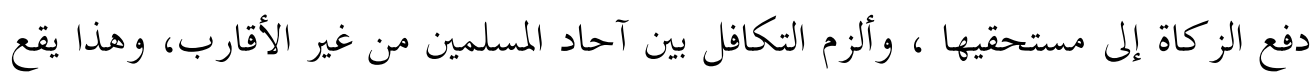

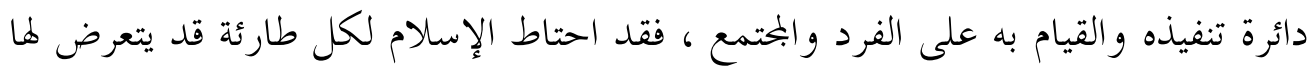

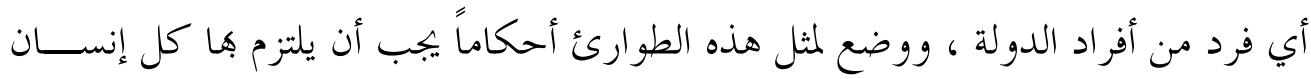

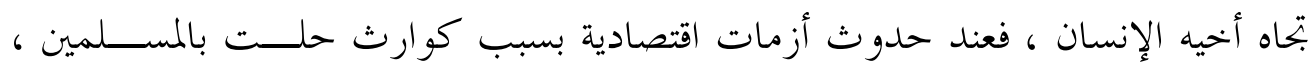

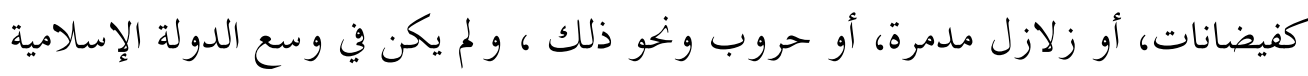

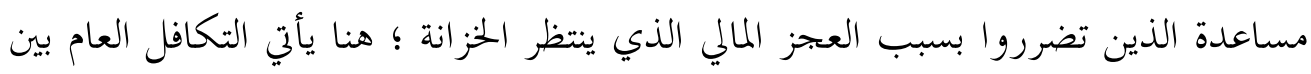

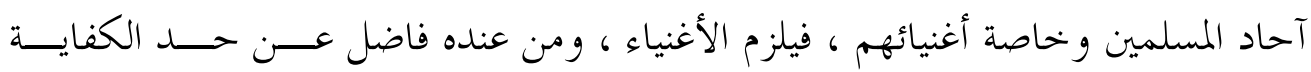

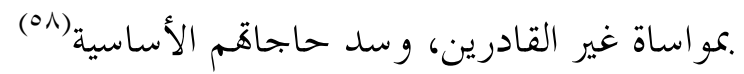

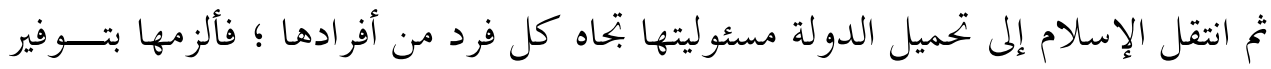

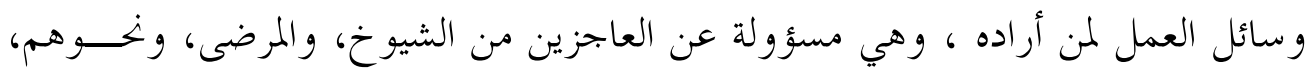

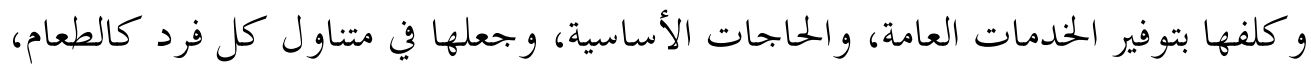


و الشراب ، و اللباس، و الأمن، والطب ، و التعليم، ، وووسائل البناء، والعمارة، ونخو ذلك مما يجتاجه الفرد، ويبحث عنه .

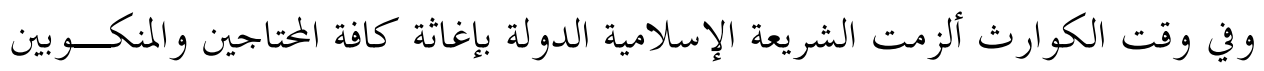

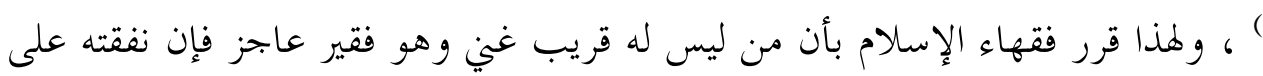
خزانة الدولة، وينفذ ذلك بطريق إداري، ويزيد فقهاء الحنفية أنه إذا لم ينفذ ذلك ولك ولي أمر برك

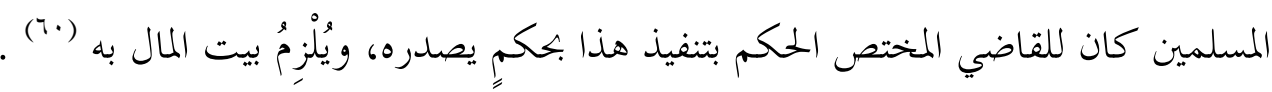
بل إن الشريعة الإسلامية الخالدة جعلت هذا الحق لكل رعايا الدولة مسلمين ومعاهدين

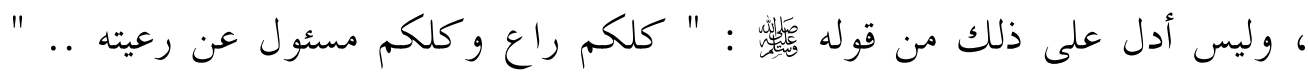

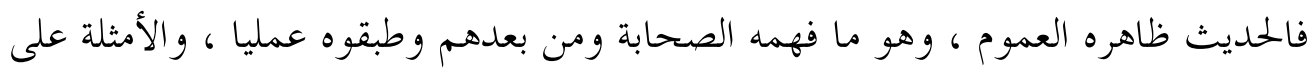

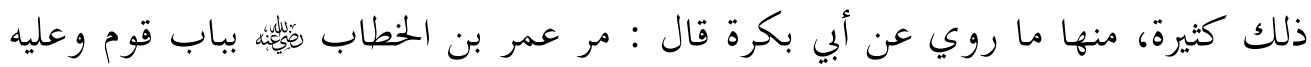
سائل يسأل: شيخ كبير، ضرير البصر، فضرب عضده من خلفه، وقال: من أي أهل

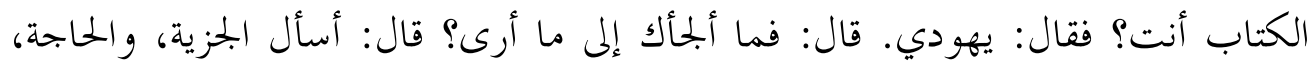

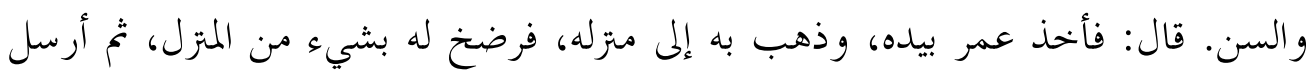

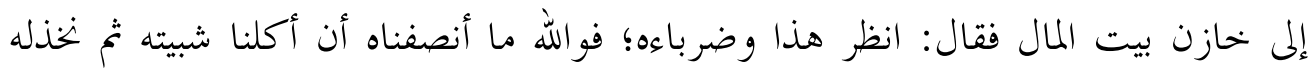
عند الهرم "إنما الصدقات للفقراء والمساكين"، والفقراء هم المسلمون، وهذا من المساكين من أهل الكتاب، ووضع عنه الجزية وعن ضربائه. قال: قال أبو بكرة: أنا شهدت ذلك من من ونه

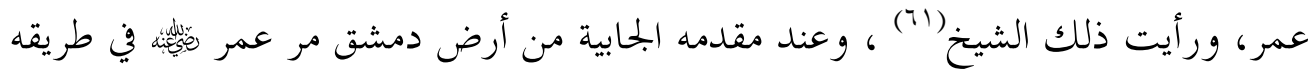

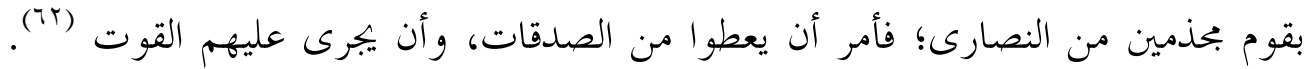

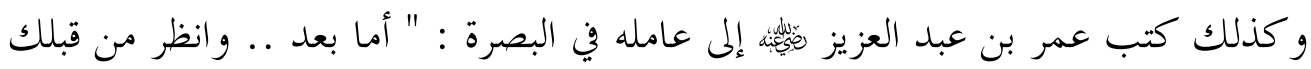
من أهل الذمة قد كبرت سنه ، وضعف قوته ، ووولت عنه المكاسب ؛ فأجر عليه من بيت

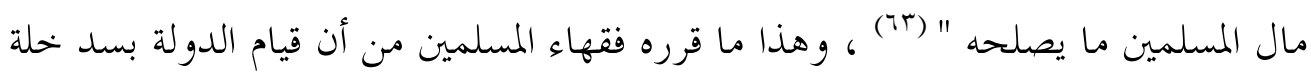

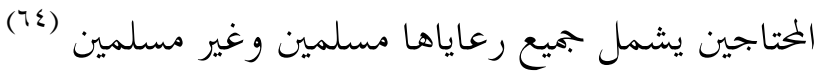

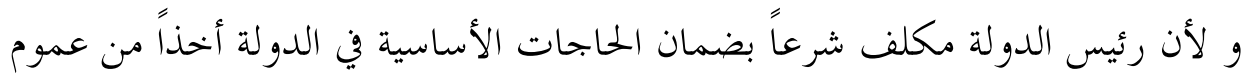
قوله بـ 


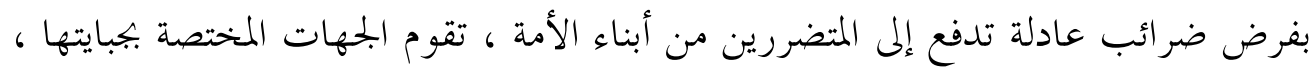

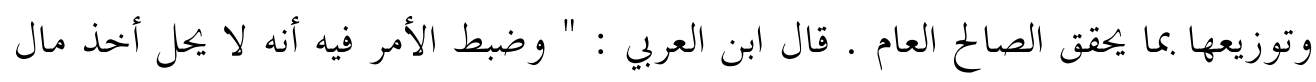

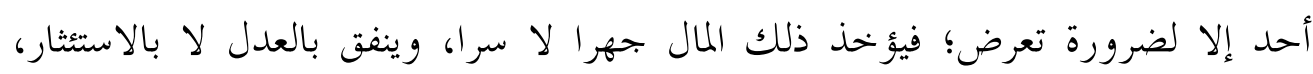

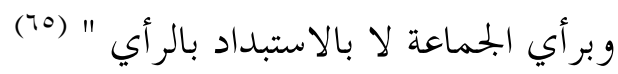

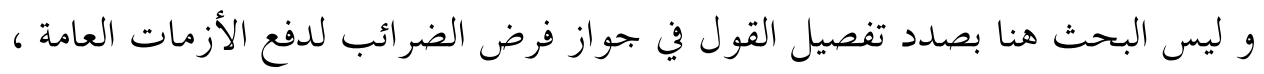

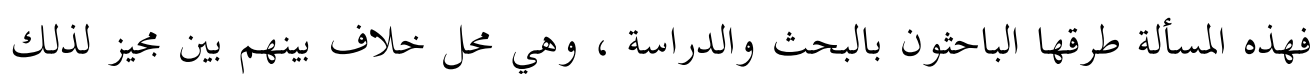

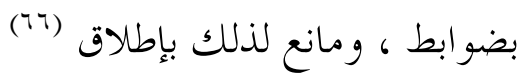

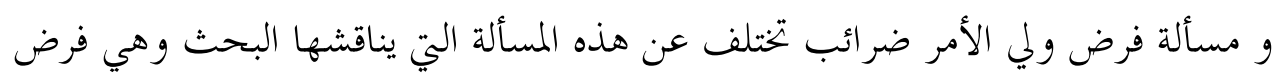

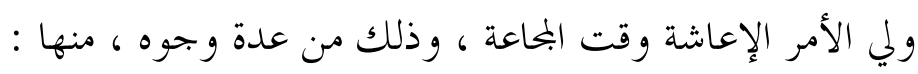

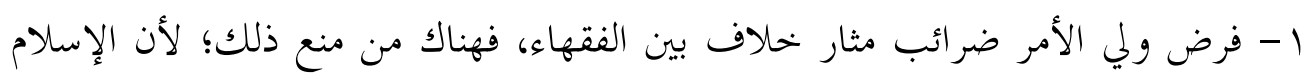

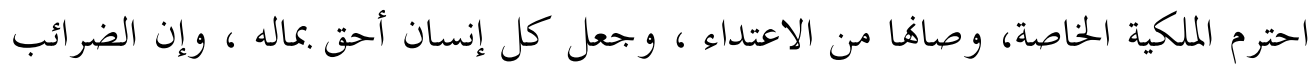

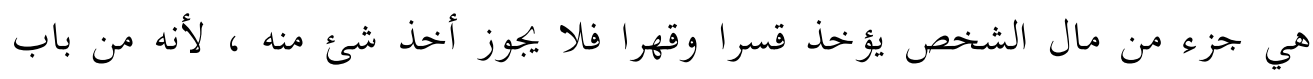

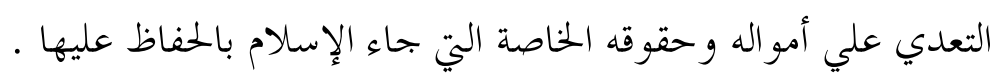

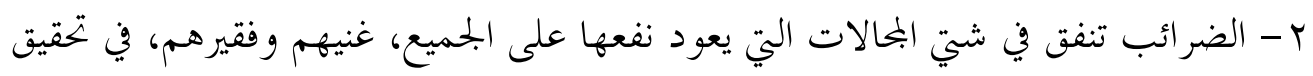

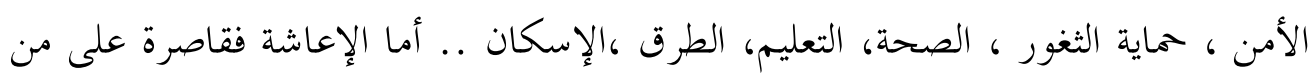

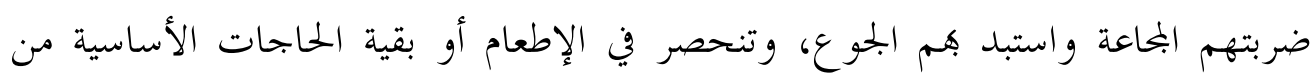

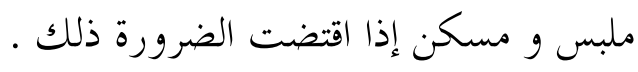

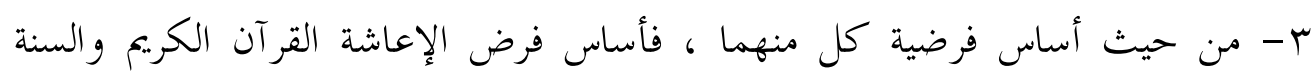

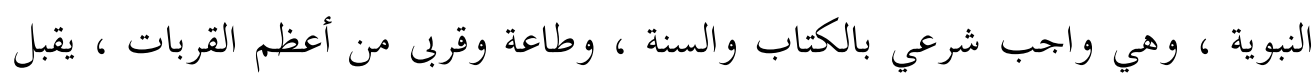

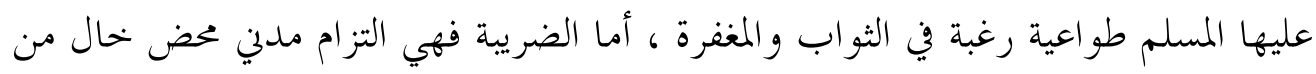

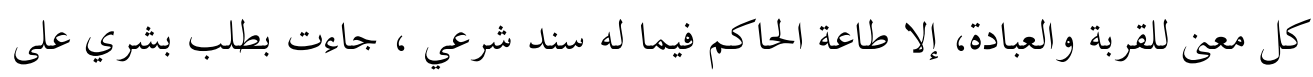

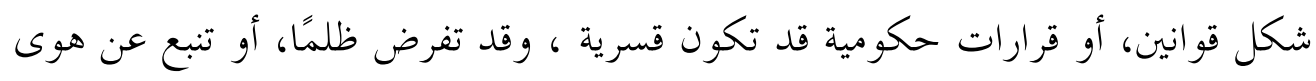

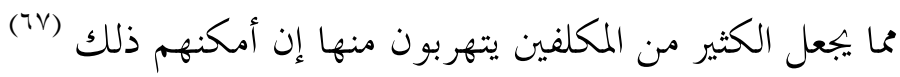


ع - أن إعاشة الناس بعضهم بعضا وقت الكوارث والنوازل واجب عليهم شرعا ، يجب

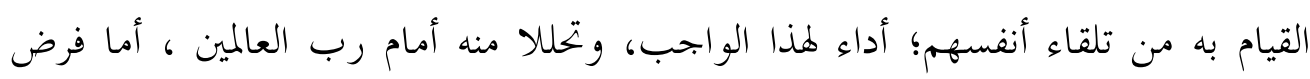

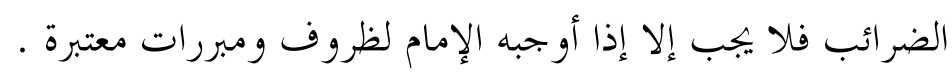

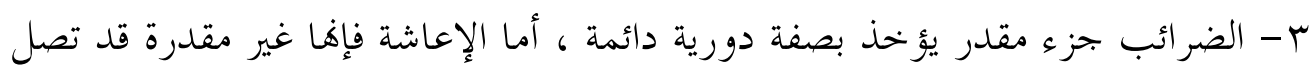
إلى درجة المقاسمة في الطعام والشراب ، بأن يفرض على كل بئ بيت تكفيه موارده لسد

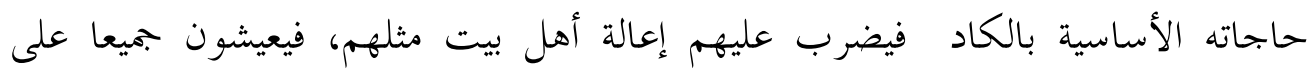

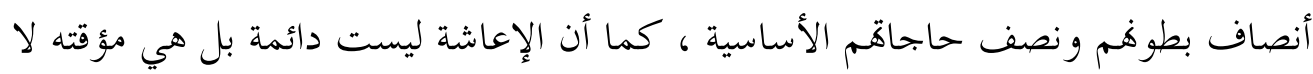
تلبث أن تزول بزوال أسبابها . يعود البحث إلى مسألة فرض الإعاشة إذا ما وقعت كارثة من الكوارث ( سيول وفيضانات - زلازل وبراكين - أوبئة - جفاف شديد - حروب دإمية إدية ) ونتج عن هذه الكارثة وقوع بجاعة ضربت البلاد بطولها وعرضها، فهل يجوز لولي الأمر ( رئيس الدولة )

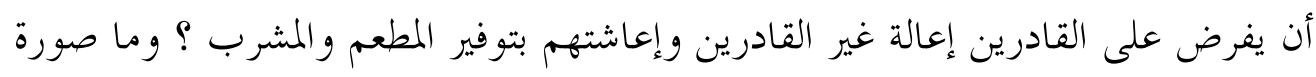
ذلك ؟ وما القيود التي ترد على هذا التصرف ؟

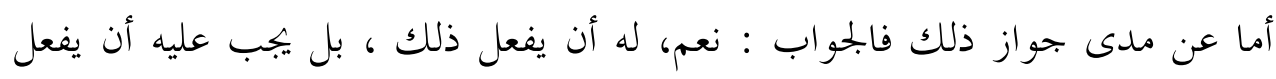

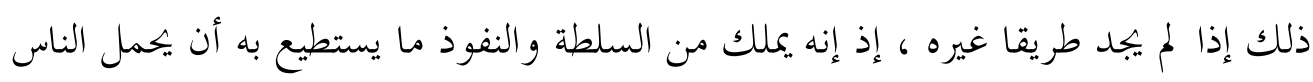

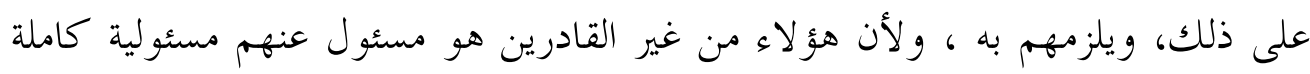

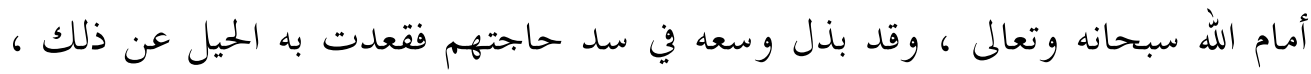
فلجأ إلى فرض الإعاشة التي هي واجب شرعي بالأساس ، فمن حق ولي الأمر أن يتدخل

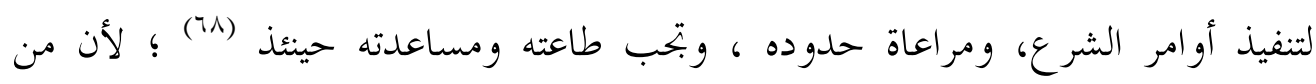
حقوق رئيس الدولة في الفقه الإسلامي نصرته إذا ما كان يسير في حكمه على مقتضى

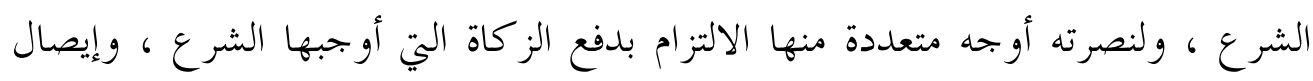
الحقوق المترتبة علي أفراد الرعية من عشور وحقوق أخرى ، وقدة وقد تكون النصرة بتحمل

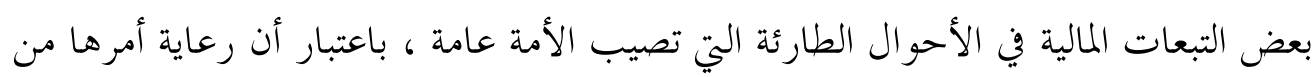

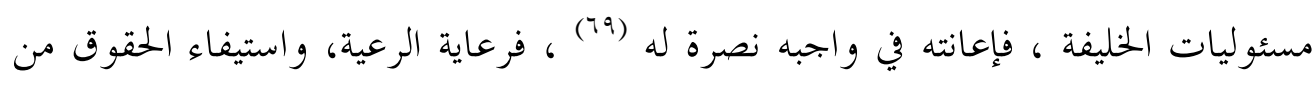


الممتنعين، وإيفاؤها على المستحقين من واجبات الإمام ، يقول الإمام الجويني : " الإمامة

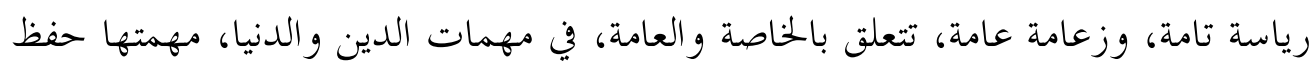

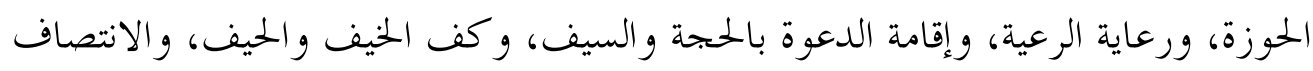

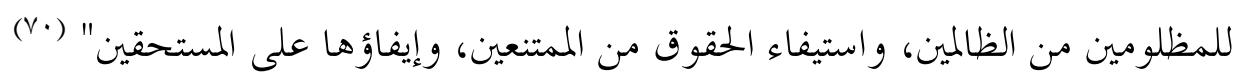
والأدلة على جواز ذلك أو وجو به ، تتمثل فيما يلي :

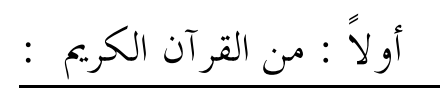

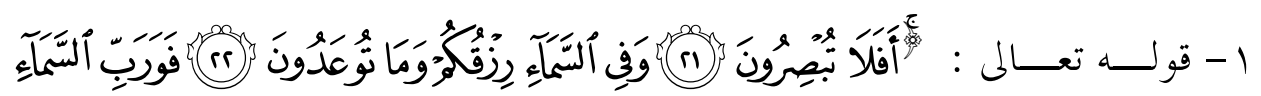

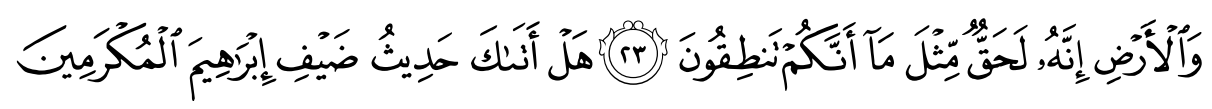

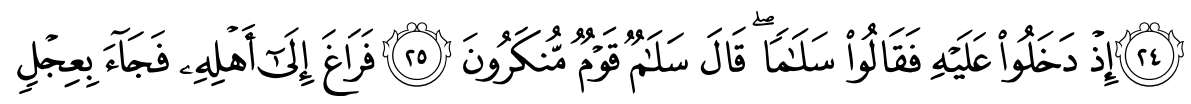

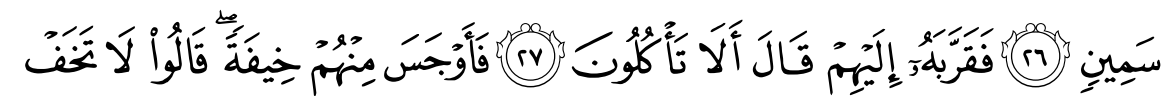

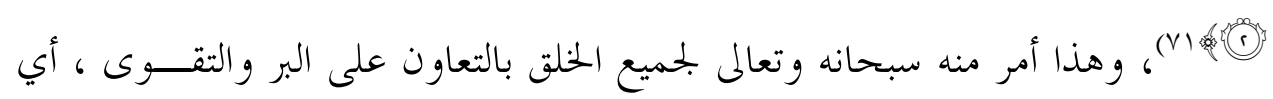

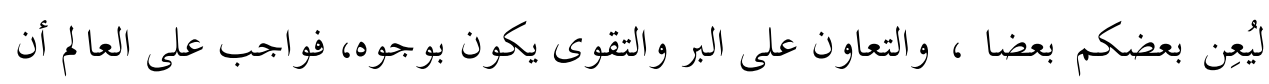

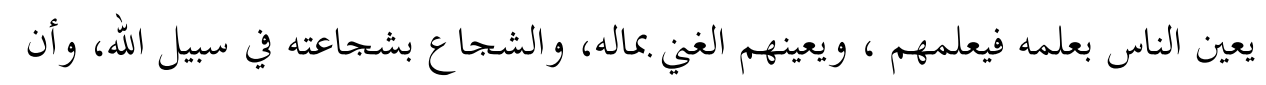

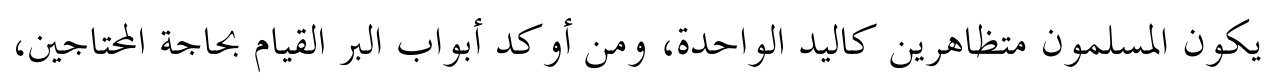

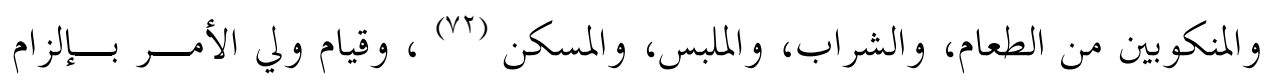

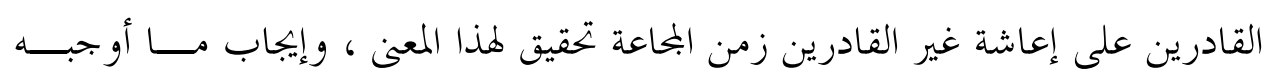
القرآن الكريم داخل في سلطة ولي الأمر .

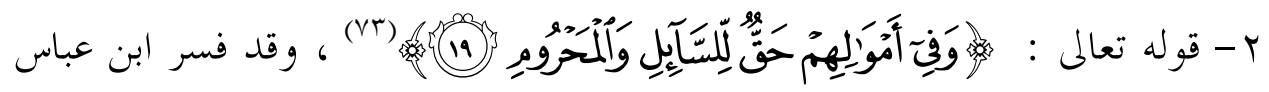

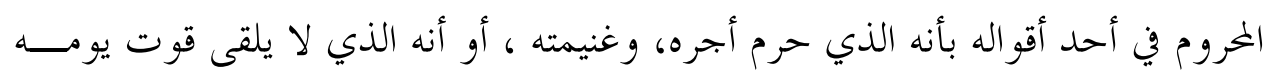

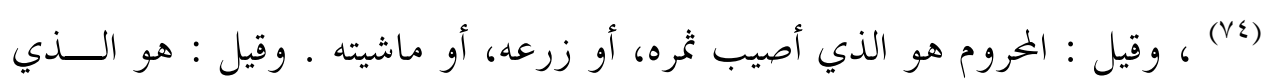

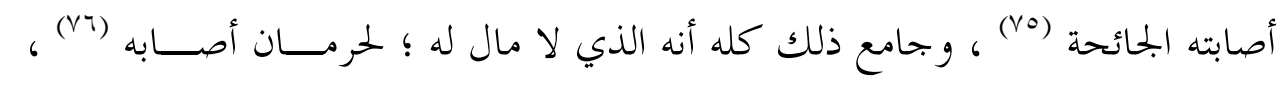

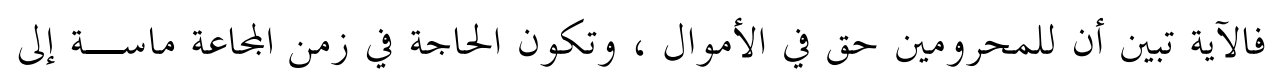


استيفاء هذا الحق ، ولا شك أن هذا داخل في سلطة ولي الأمر، ومن أوجب و اجباتـــ

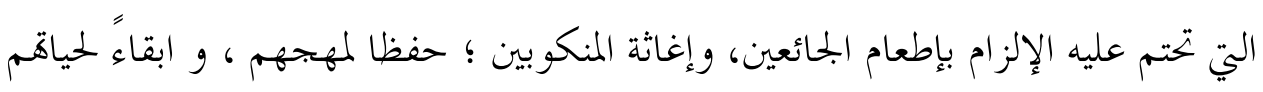

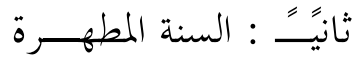

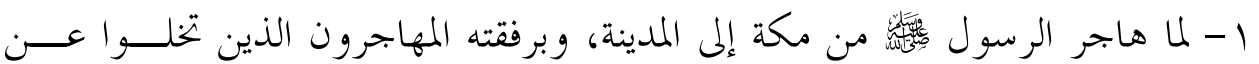

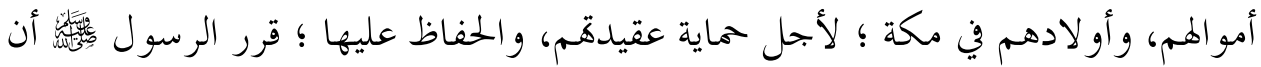

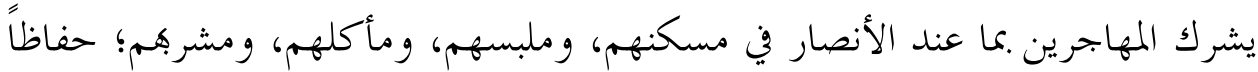

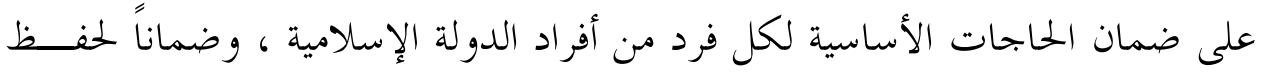
التوازن الاقتصادي الذي يمليه عليهم دينهم، وعقيدقم ، لهذا يشير القرطبي في تفسـيره

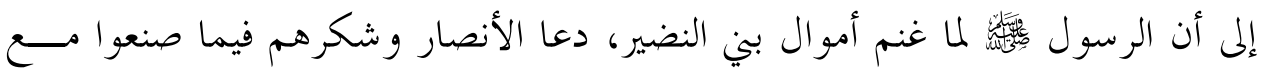

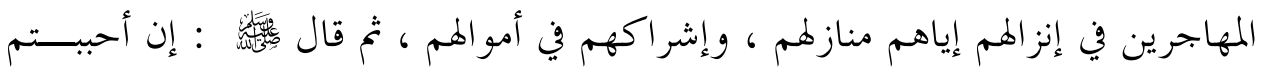

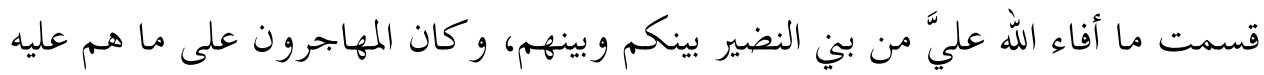

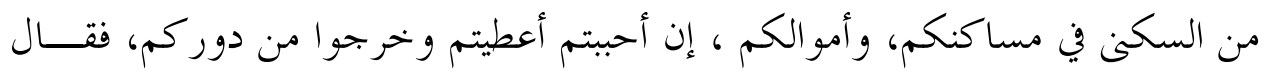
سعد بن عبادة وسعد بن معاذ : بل تقسمه بين المهاجرين، ويكونوا في دورنا ، وقــــال الأنصار : رضينا ؛ فقال ئس

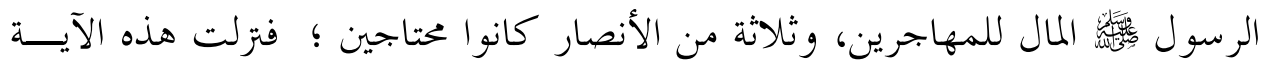

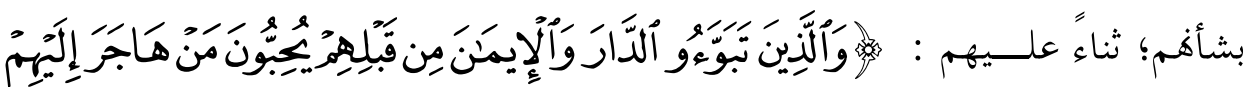

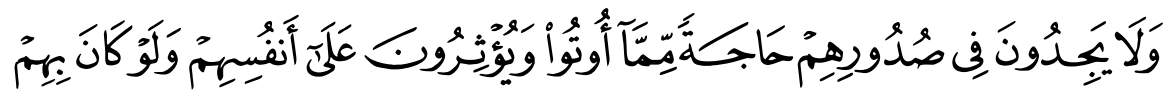

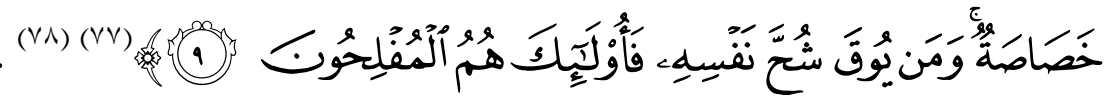

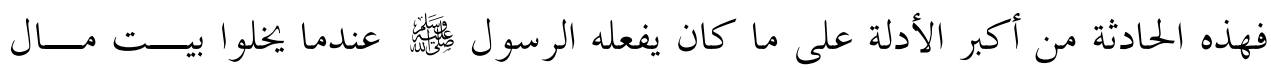

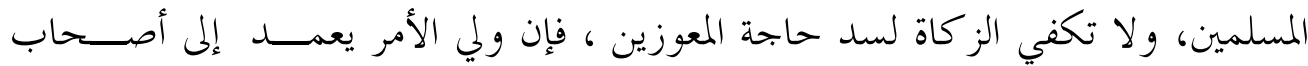

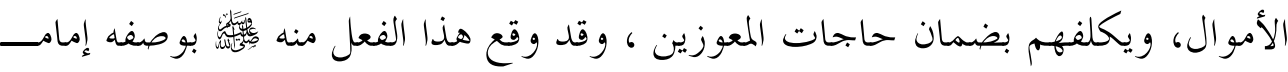


للمسلمين ، وأحوال النبي ئس

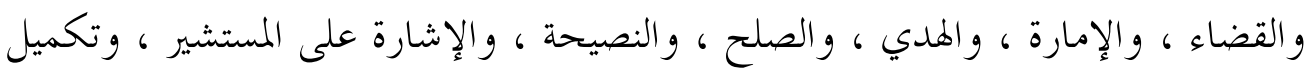

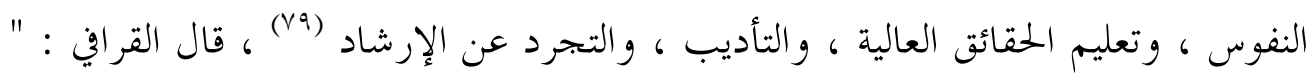
ثم تقع تصرفاته بـ بالقضاء ، ومنها ما يجمع الناس على أنه بالإمامة، ومنها ما يختلف العلماء فيه لتردده بــين

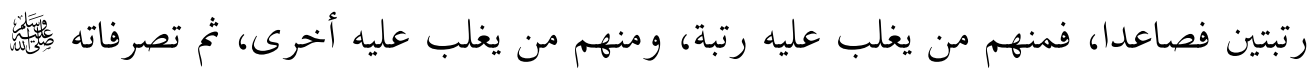

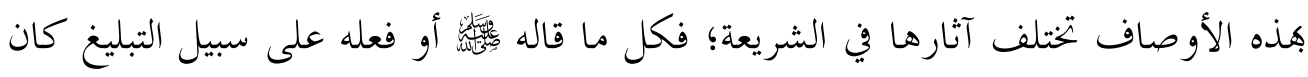

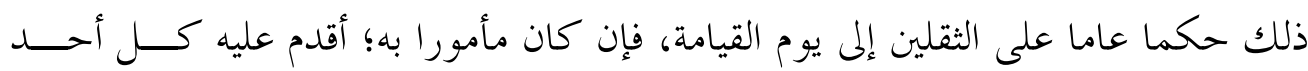

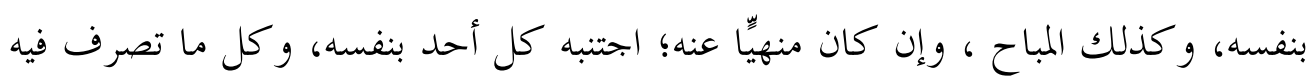

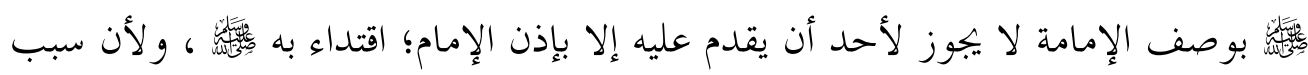
تصرفه فيه بوصف الإمامة دون التبليغ يقتضي ذلك " (•) وقد ورد في القرآن الكريم بعض وظائف الدولة الإسلامية ، في الآيات التي تخاطب النبي

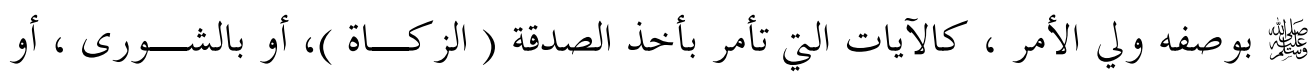
بنظام معين لمصارف الز كاة، أو الغنيمة، أو الفئ ، فهناك تصرفات للبي لئي

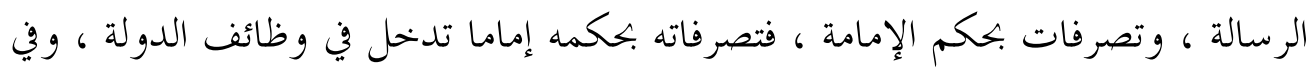

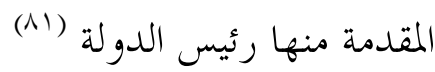

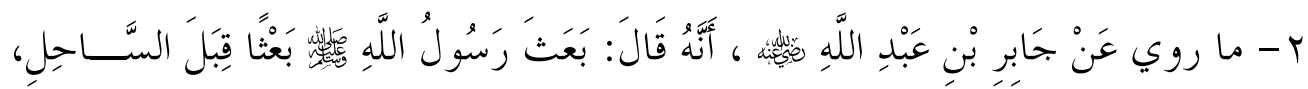

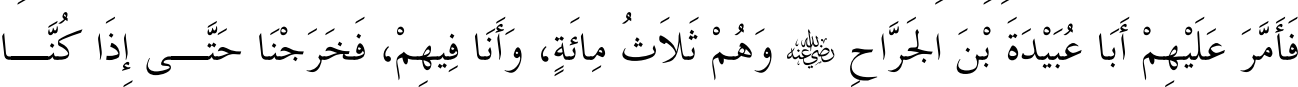

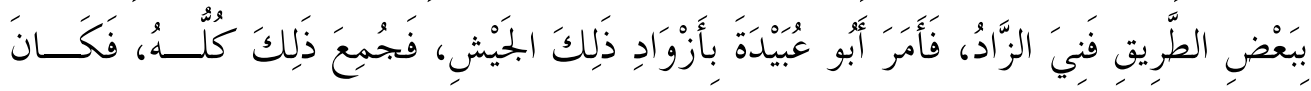

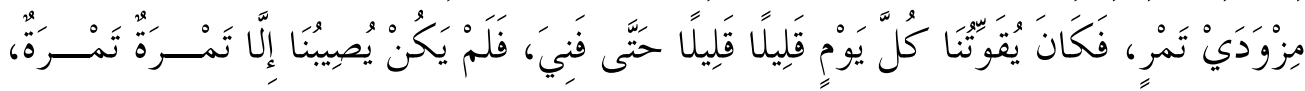

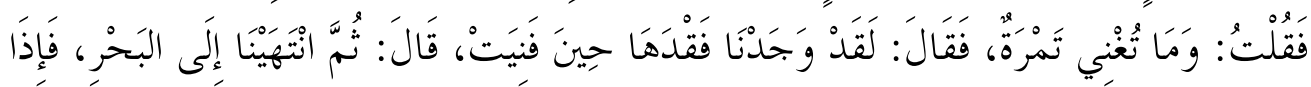

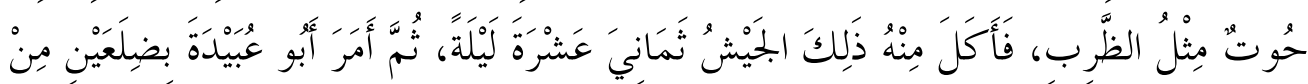

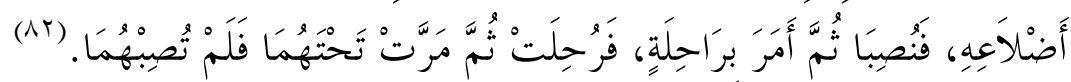


ووجه الدلالة في الحديث : أن أبا عبيدة بن الجراح وهو ولي الأمر هنا جمع بقية أزواد

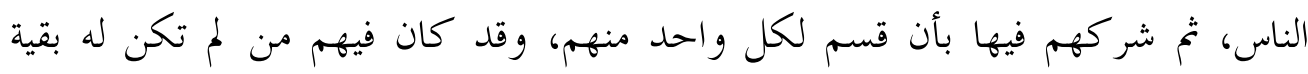

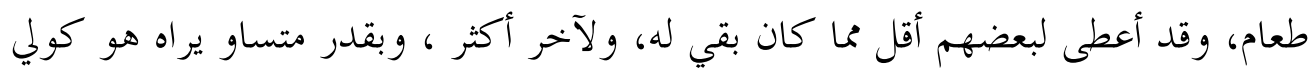

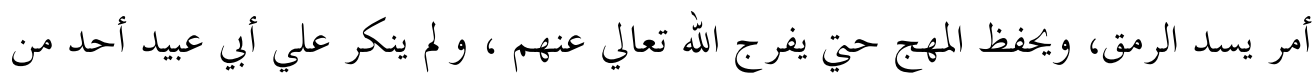

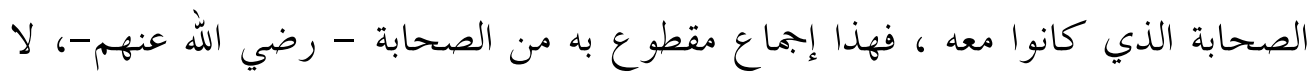
مخالف له منهم (Ni). و لهذا الحديث - وغيره - اتفق الفقهاء علي أنه من حق ولي الأمر انطلاقا من مسئوليته

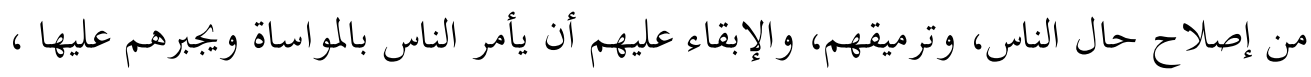

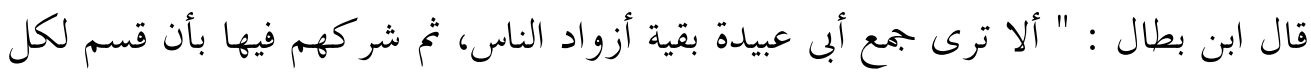

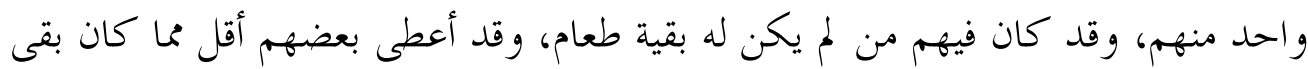

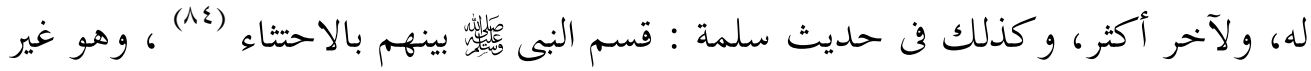

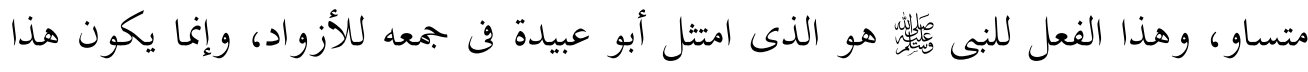

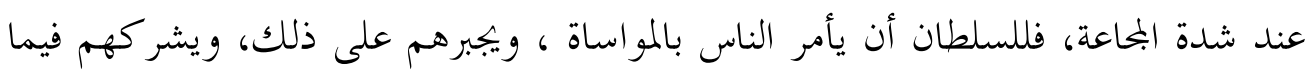

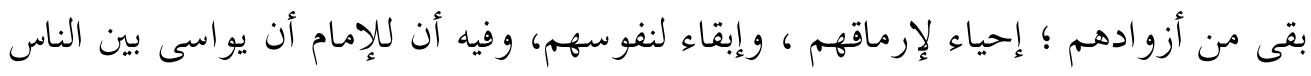

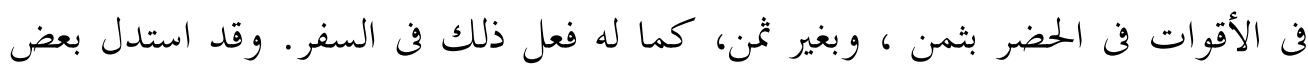

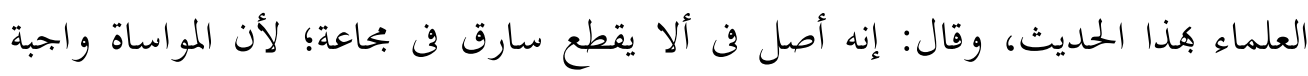

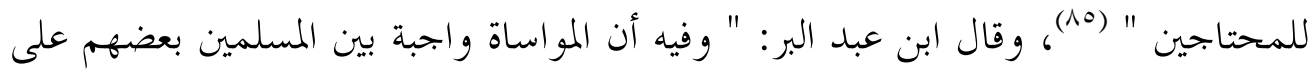

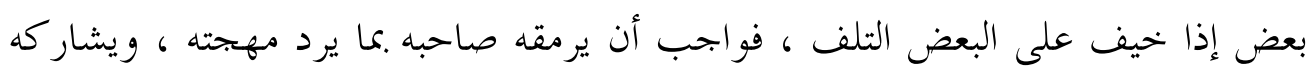

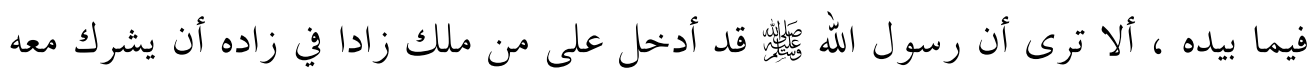

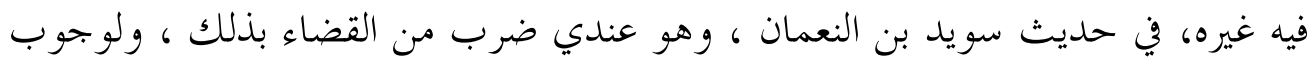

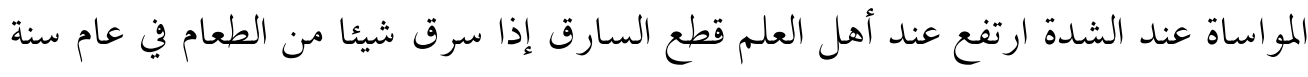

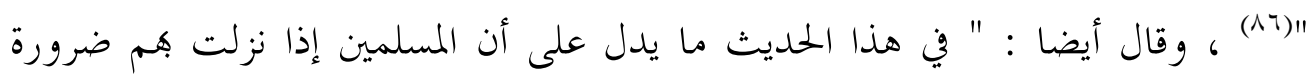

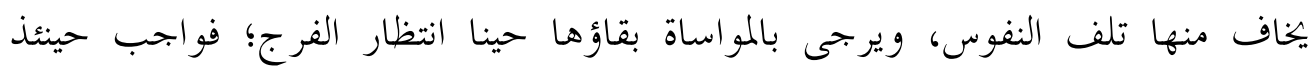

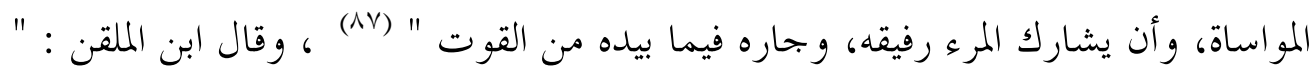


وفيه: أن لإمامام أن يواسي بين الناس في الأقوات في الحضر بثمن، وغيره، كما له فعل ذلك ألك

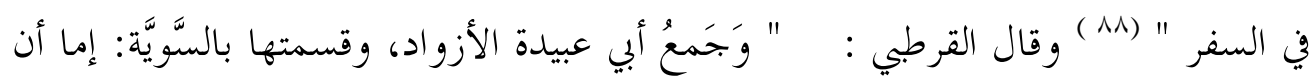

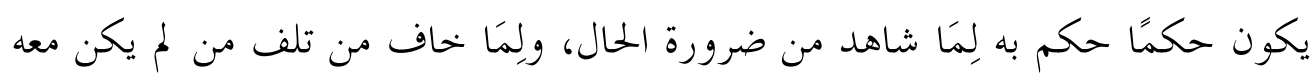

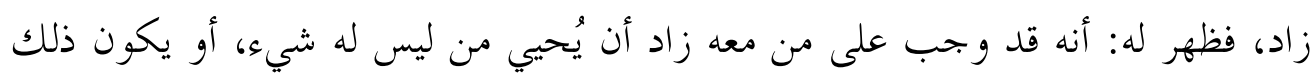

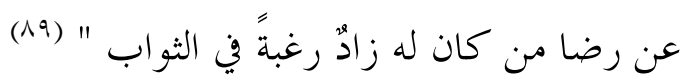

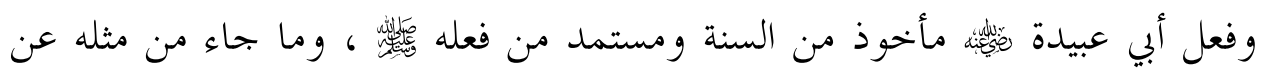

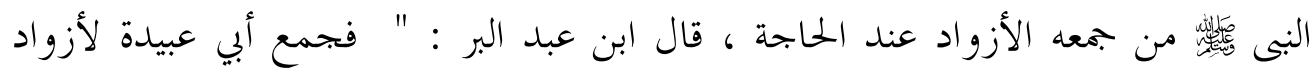

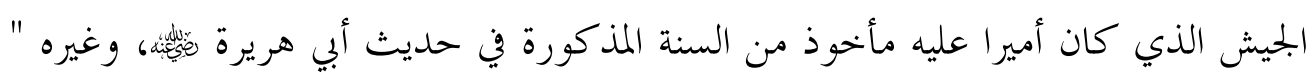

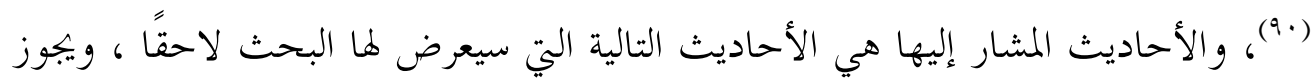

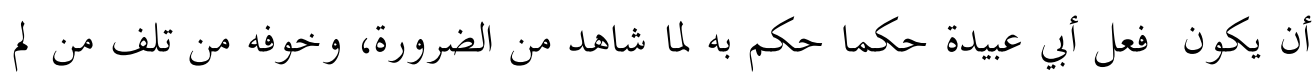

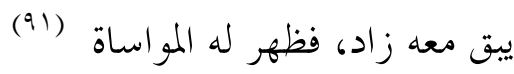

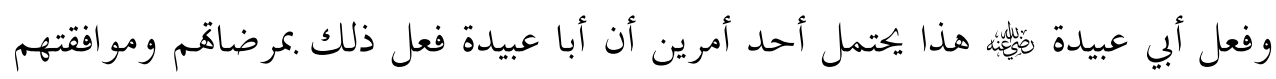

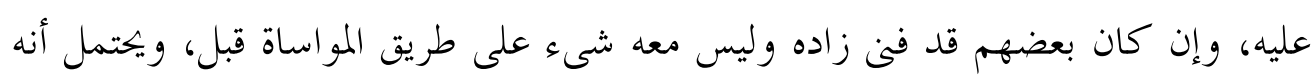

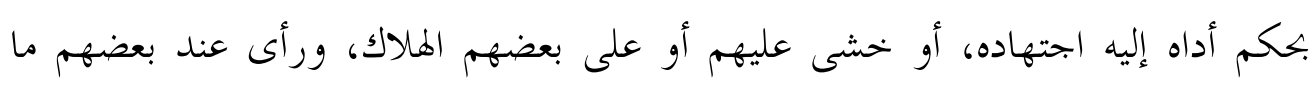
يكفيه؛ فألزمهم التساوى فيما عندهم أنساه

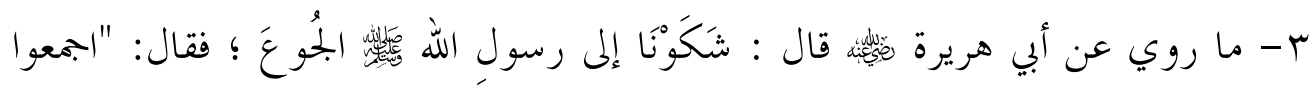

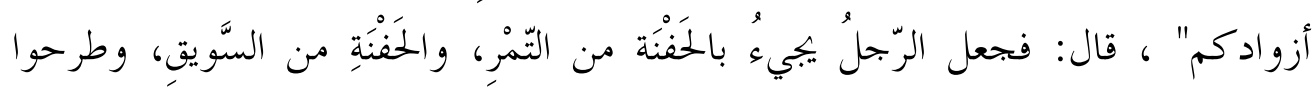

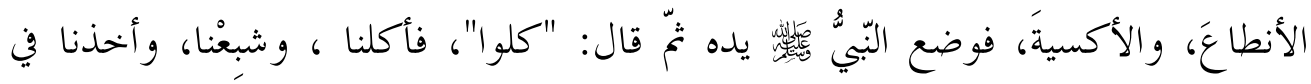

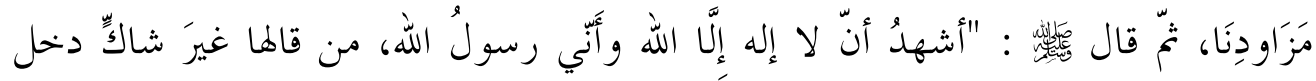

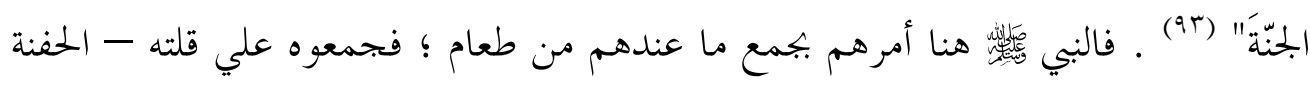

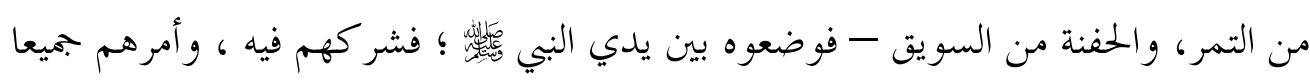

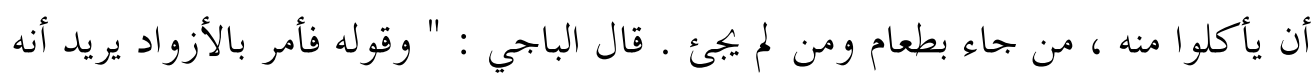

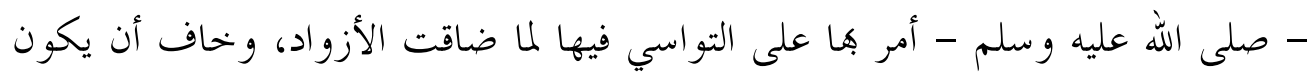

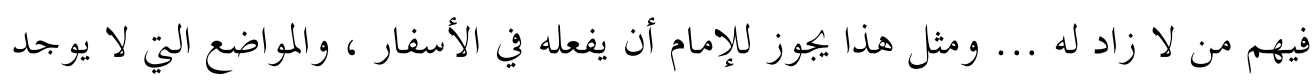


فيها الطعام ، وقد فعل ذلك أبو عبيدة في جيش الخبط " (ع9) ، وقال ابن العربي : " وفي هذا الحديث ما يدل على أن المسلمين إذا نزلت همم ضرورة يخاف منها تلف النفوس، ويرجى بالمواساة بقاؤها حينا؛ انتظارا لفرج، فواجب حينئذ المواساة، وأن يشارك المرء رفيقه وجاره فيما بيده من القوت ... وقد استدل بعض علمائنا بحديث أبي هريرة وفعل أبي عبيدة في الأمر بإخراج الأزواد و جمعها، و المو اساة على التساوي فيها، فإنه جائز للإمام عند قلة الطعام وارتفاع السعر وعدم القوت، أن يأمر من عنده طعام يفضل عن قوته بإخر اجه للبيع، و رأى أن إجباره على ذلك من الو اجب، لما فيه من ترميق الناس، و صلاح

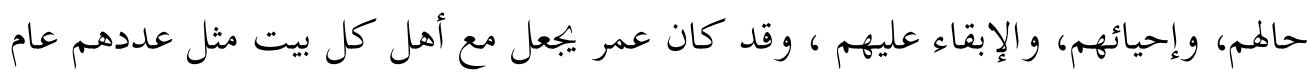
الرمادة، و يقول: لن يهلك امرؤ عن نصف قوته، وهذا كله في معنى الأزواد التي أتت

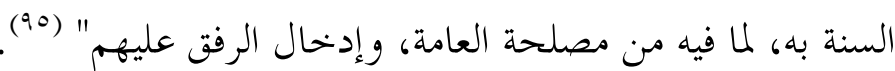

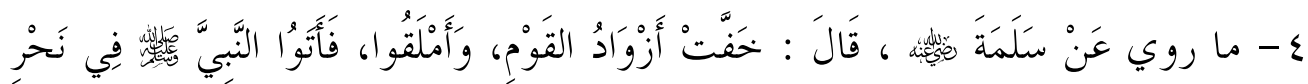

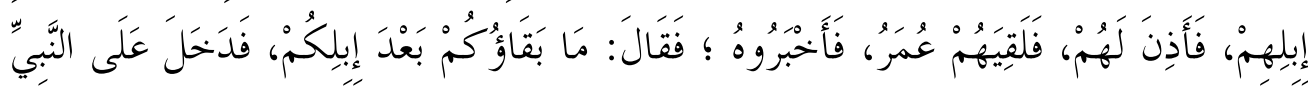

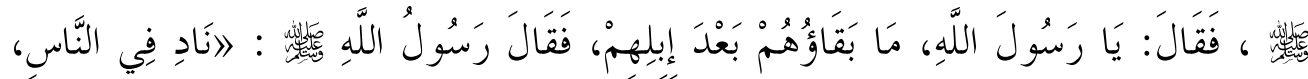

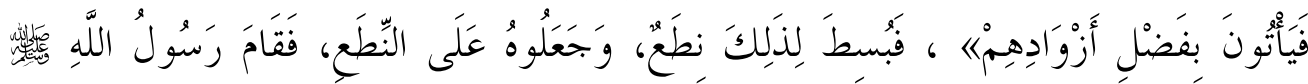

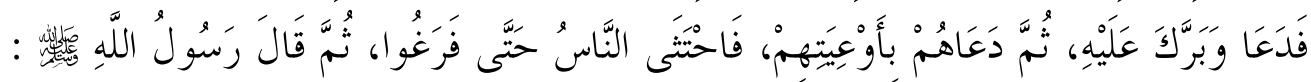

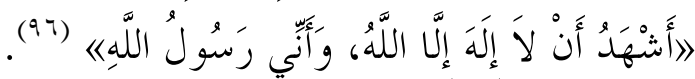

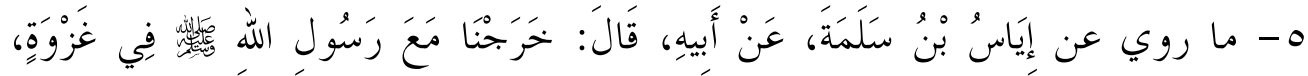

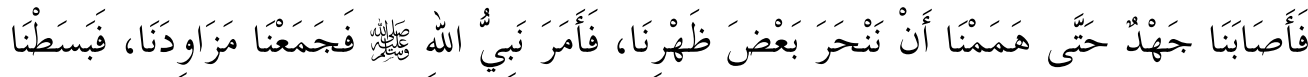

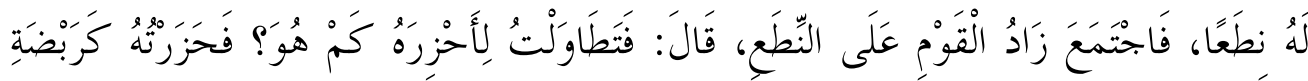

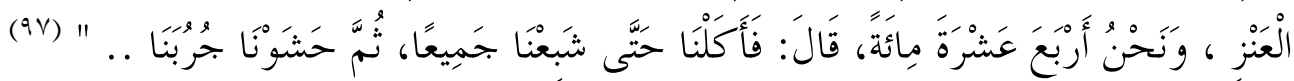

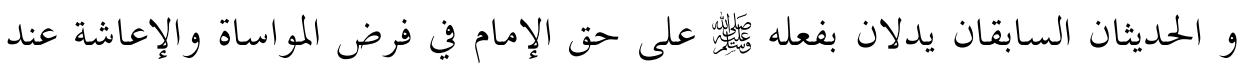

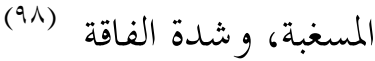

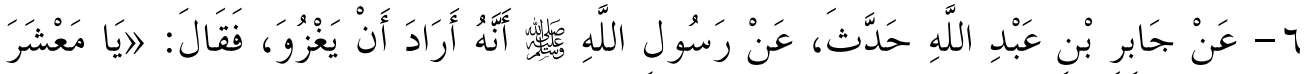

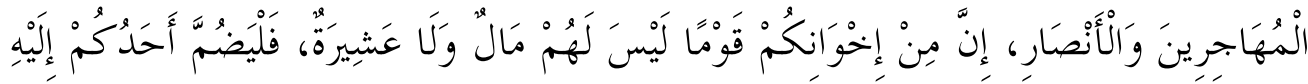




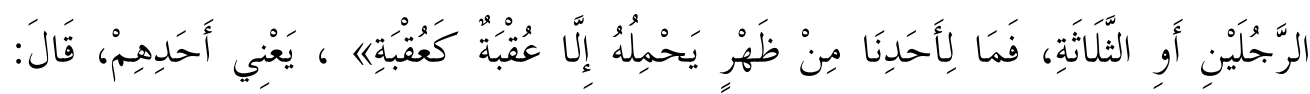

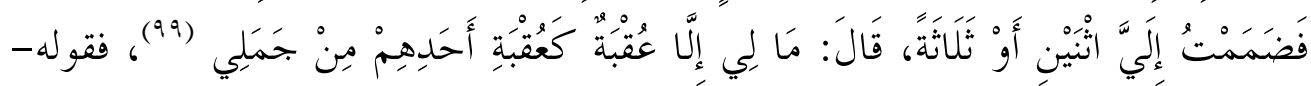

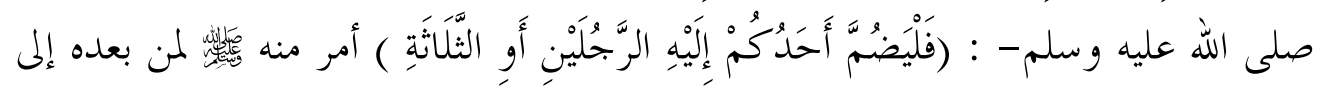

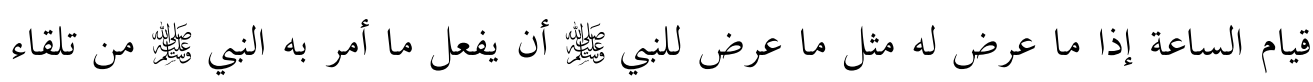

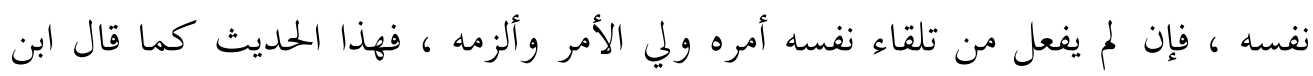

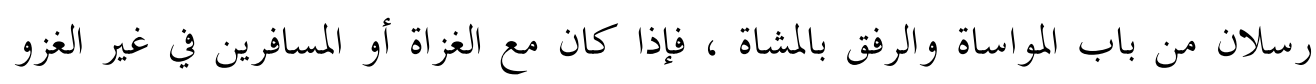

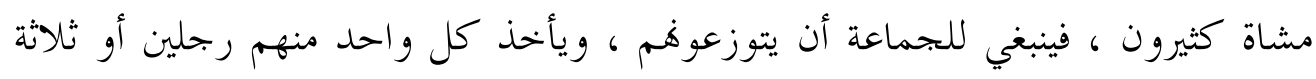

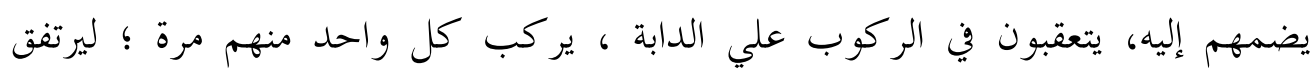

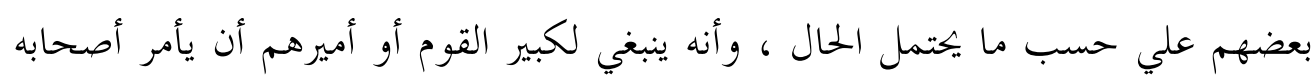

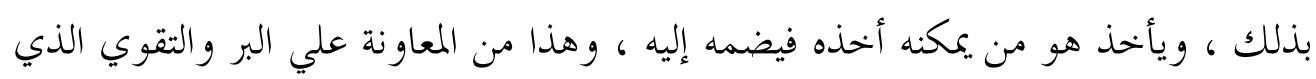

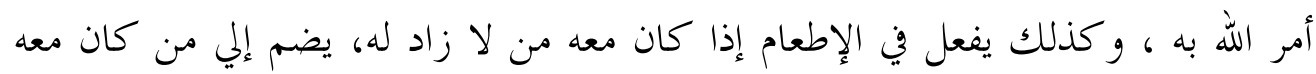

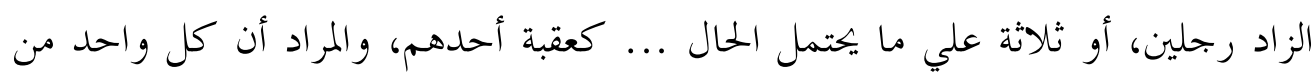

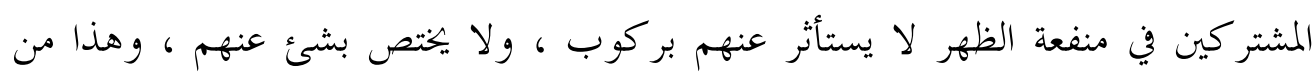

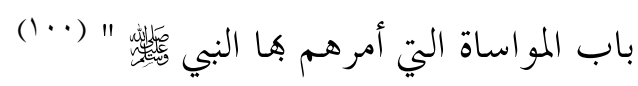

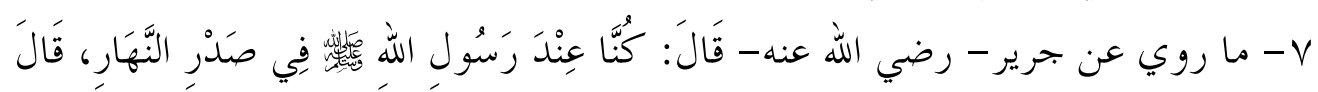

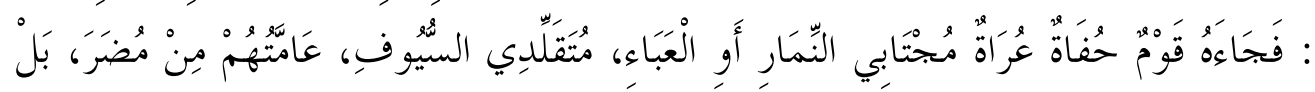

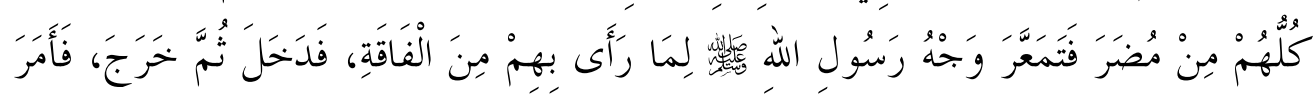

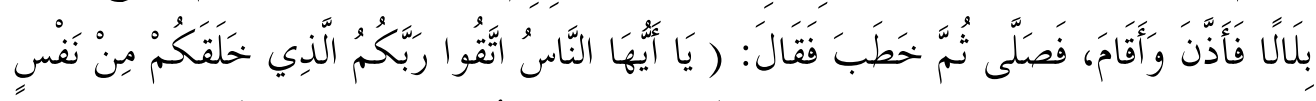

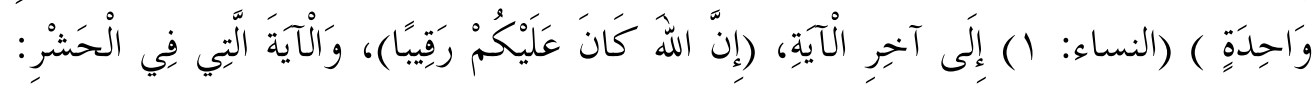

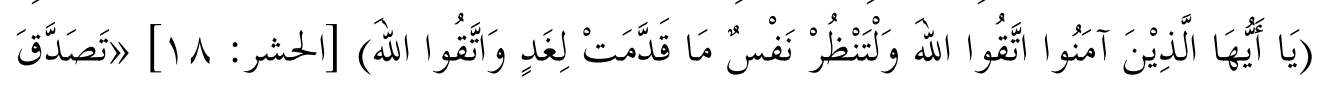

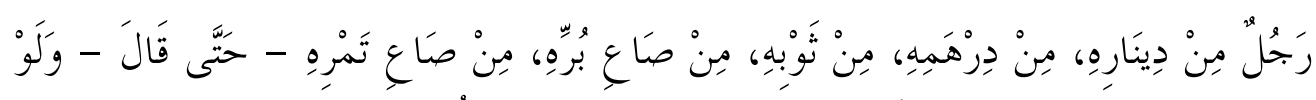

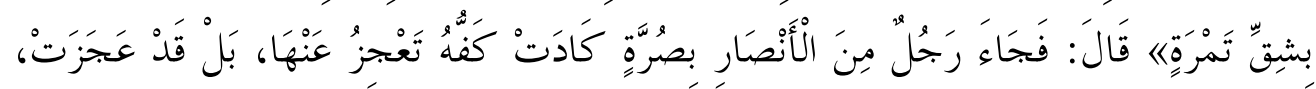

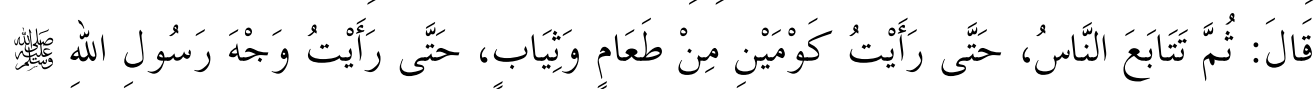

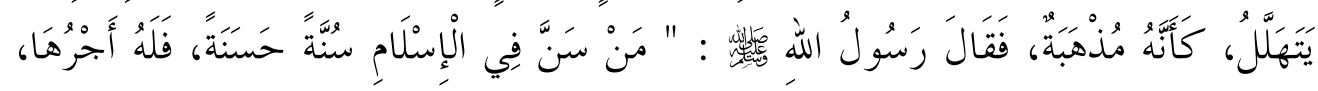




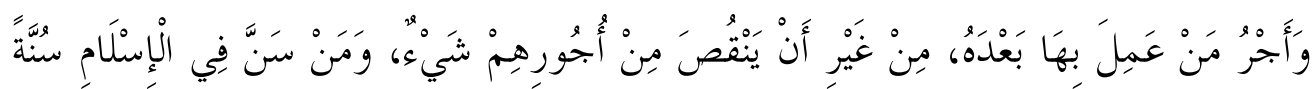

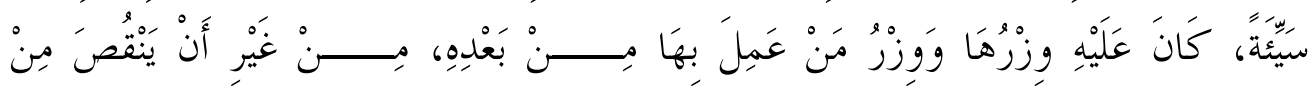

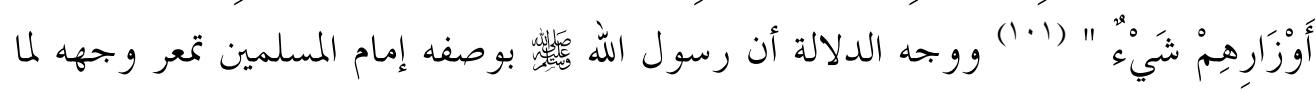

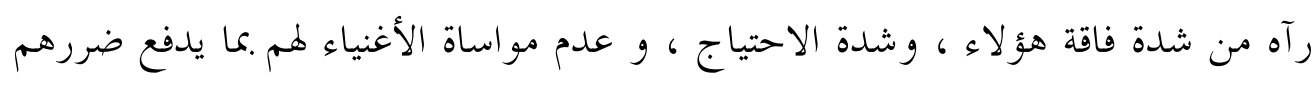

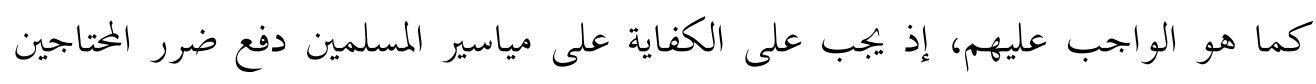

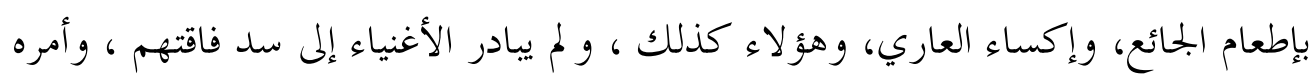

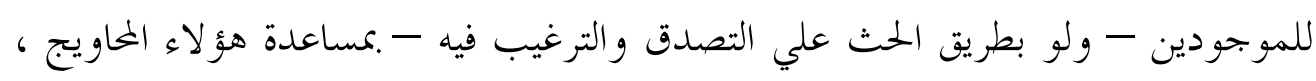

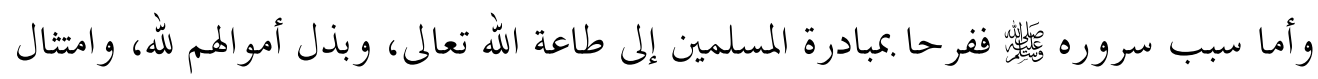

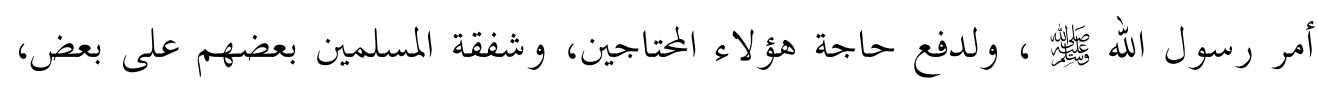

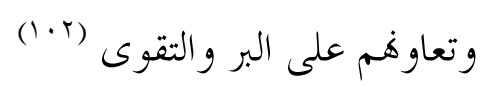

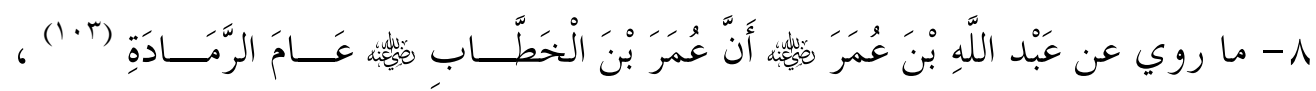

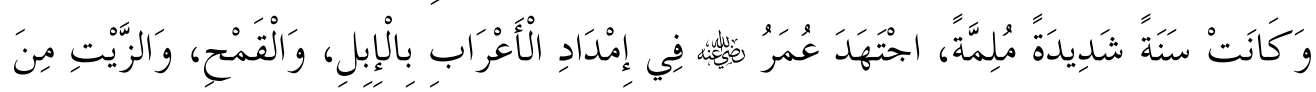

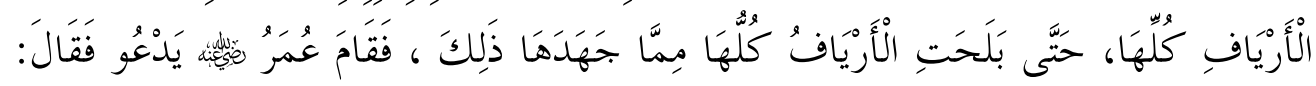

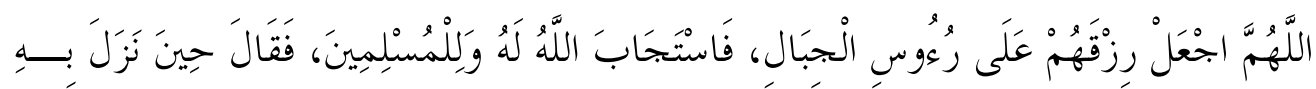

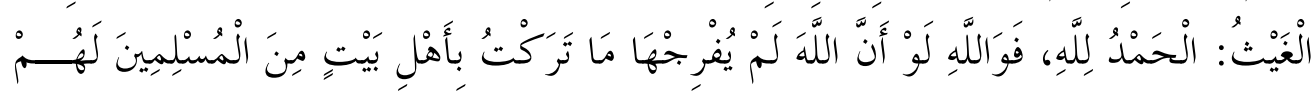

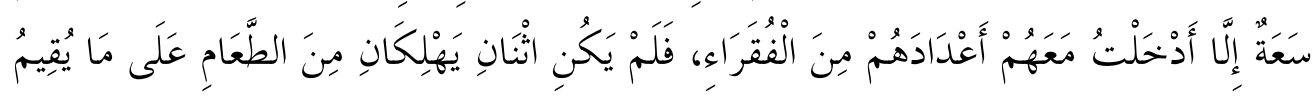

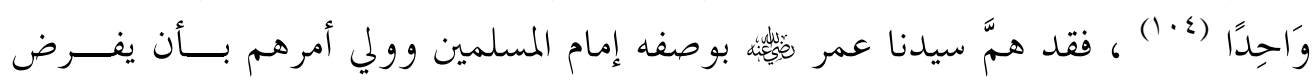

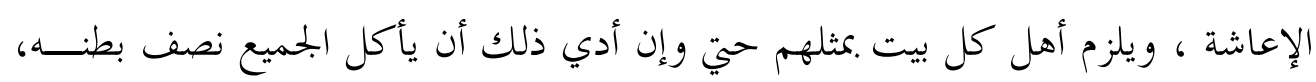

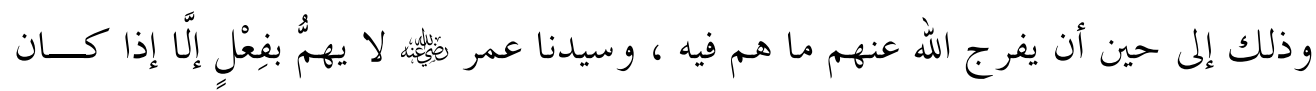

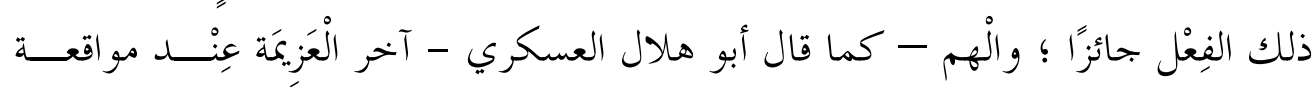

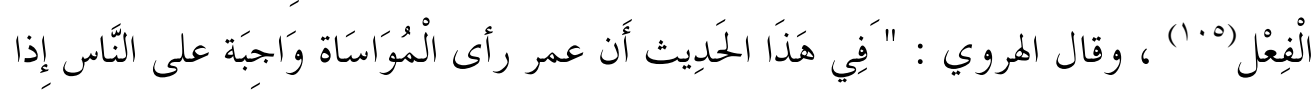

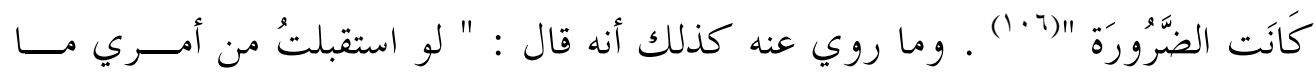

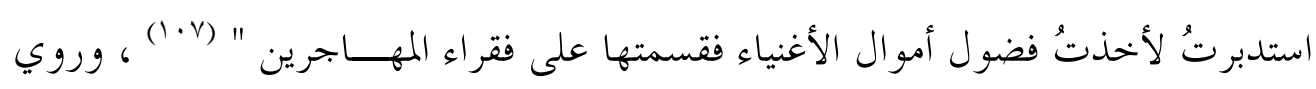

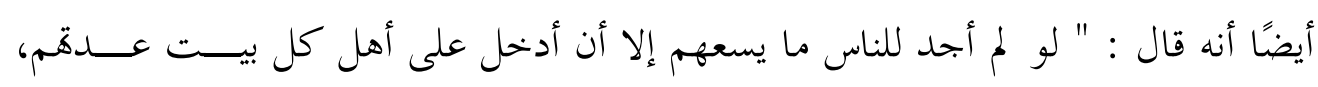




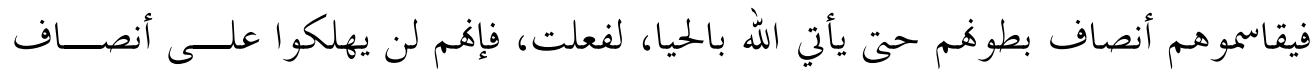

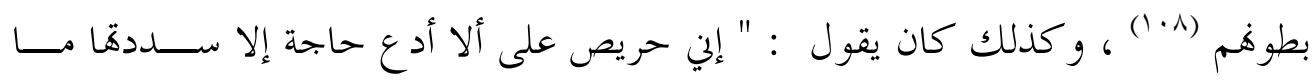

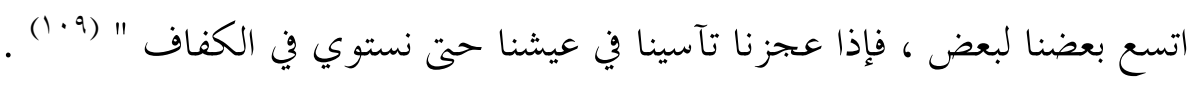

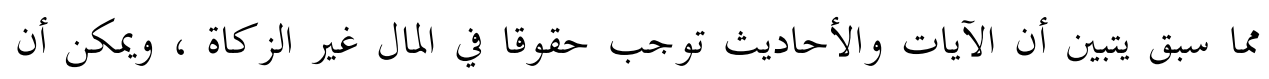

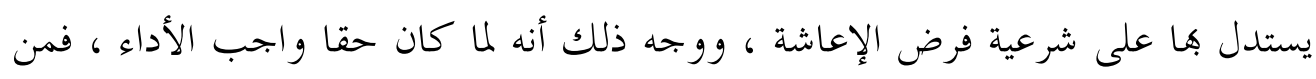

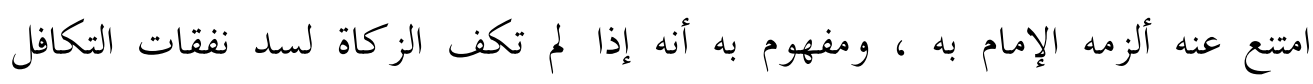

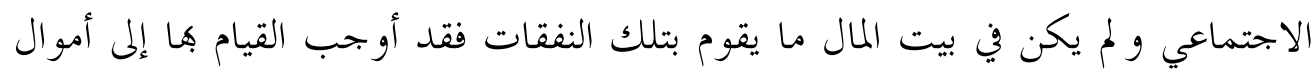

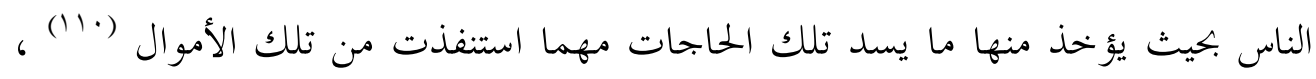

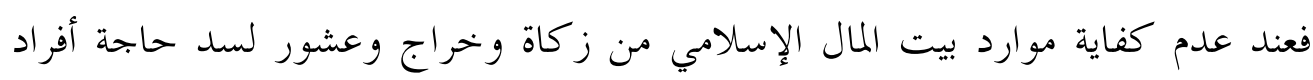

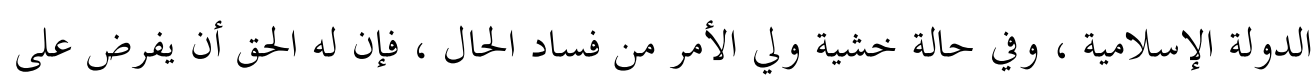

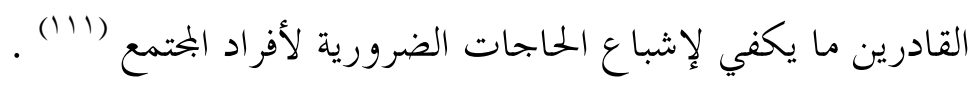

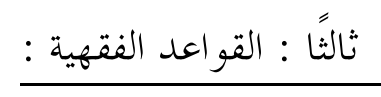

يؤ كد شرعية فرض الإعاشة والإلزام ها القواعد الفقهية ، من هذه القواعد الفقهية :

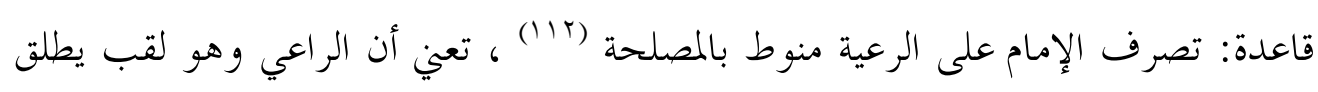

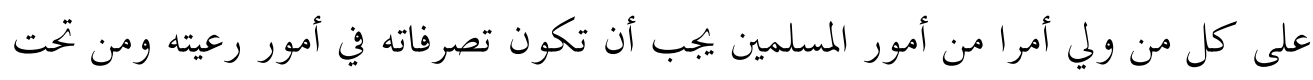

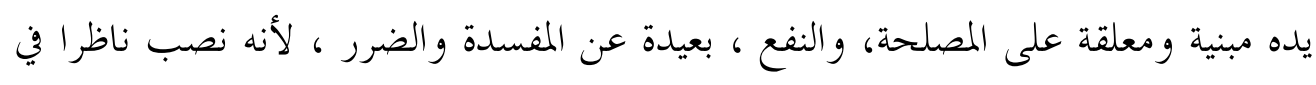

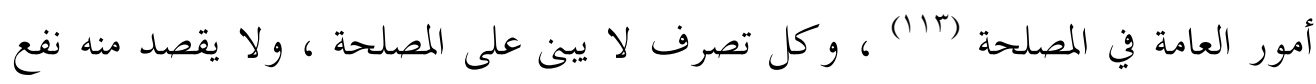

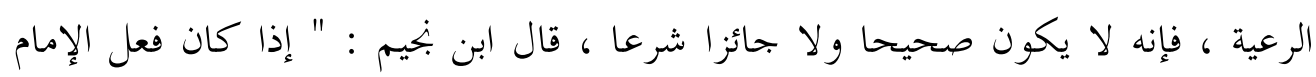

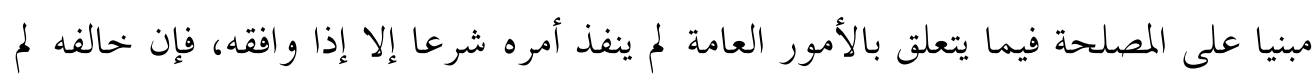

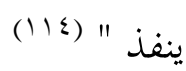

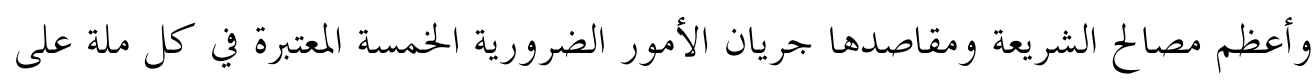

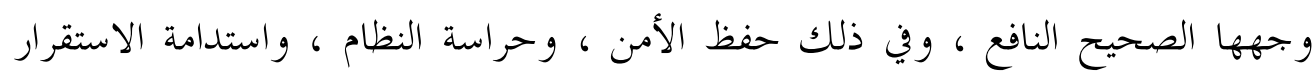

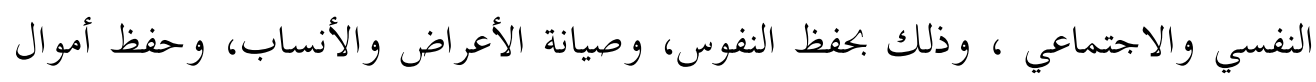

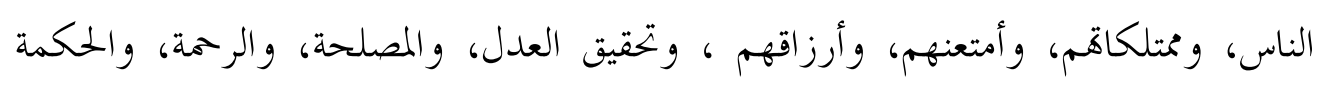


فيهم (10) ، و لا شك أن فرض الإعاشة، وإنقاذ الجوعى من غائلة الجحوع وما يترتب عليه

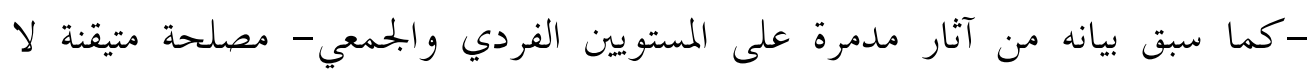
مظنونة، تقوم على مقصود الشرع في حماية الدين، و الدنيا .

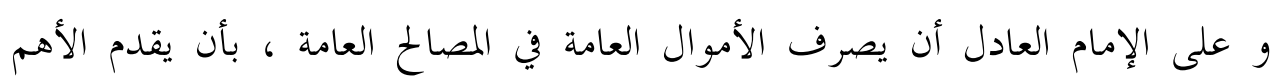

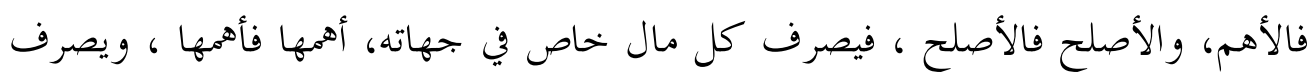

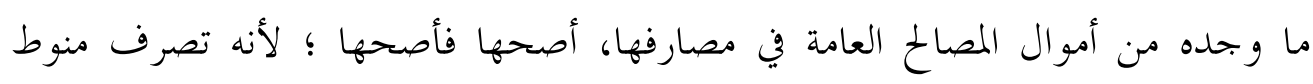

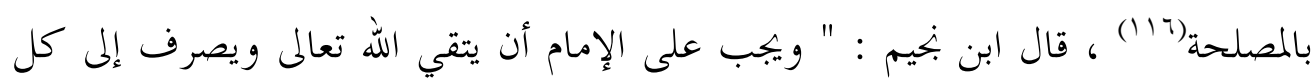

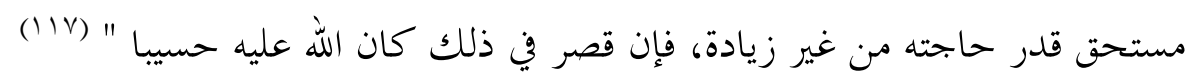
و من تلك القواعد التي تشهد لشرعية فرض الإعاشة والإلزام بها قاعدة : يتحمل الضرر

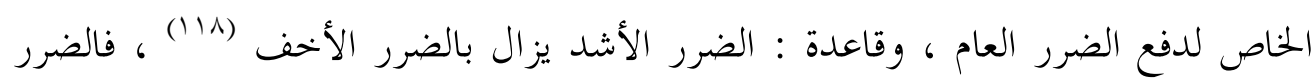

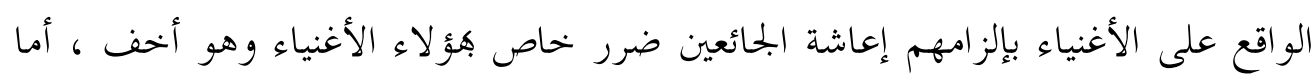

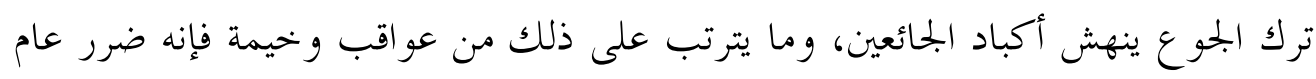

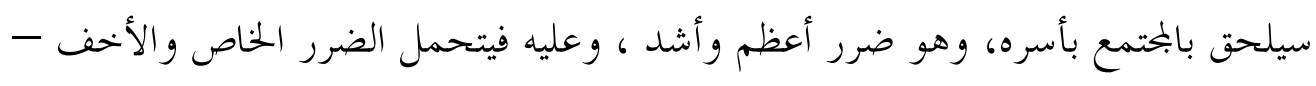

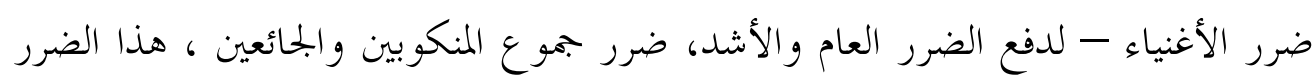

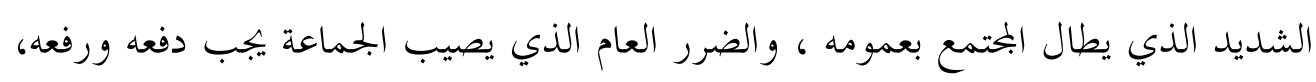

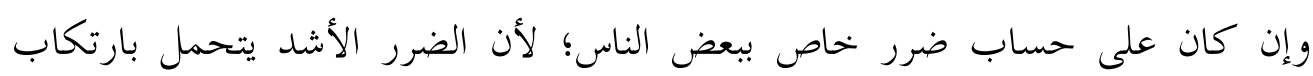

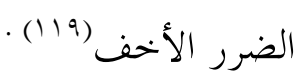

كذلك من هذه القو اعد قاعدة : ما لا يتم الواجب إلا به فهو و اجب (.rا') ، وإطعام

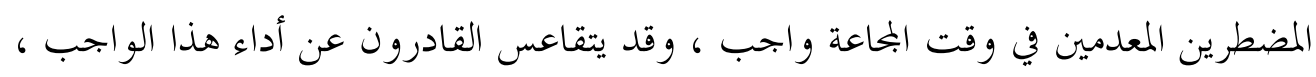

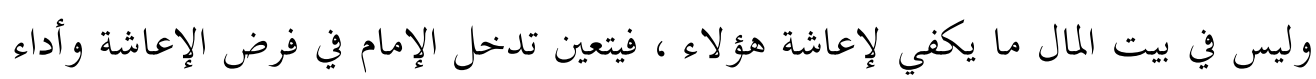

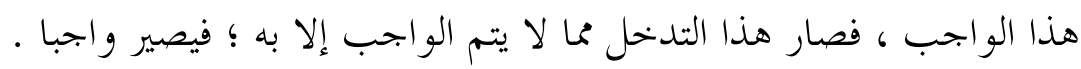
ولا ريب أن تحكيم هذه القواعد الشرعية لا يؤدى إلى إباحة فرض الإعاشة، بل يحتم

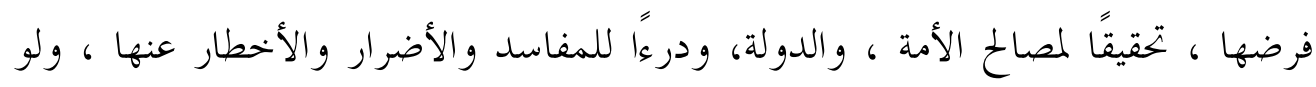

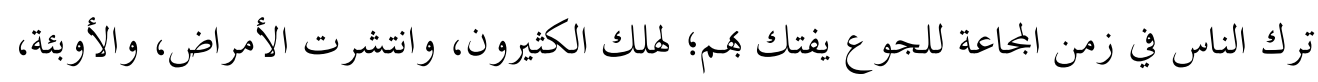


واحترقت القيم، والأخلاق ، وانتشرت الجريمة، وهتكت الأعراض، ووقعت تصرفات

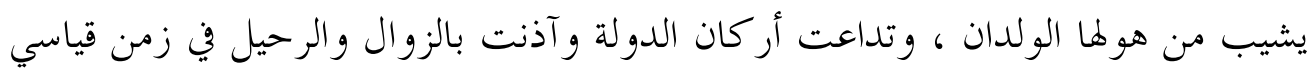

وقد أفتى علماء المسلمين في عصور مختلفة بوجوب إمداد بيت المال .بما يلزمه من ضر ائب

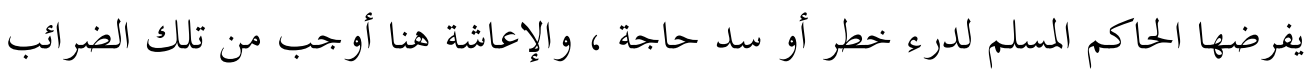

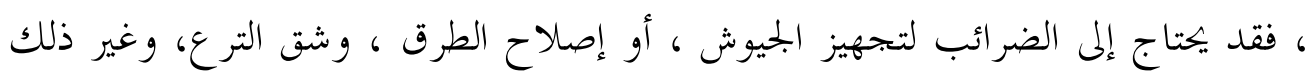

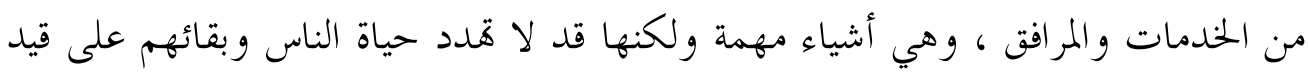
الحياة، بخلاف الإعاشة اللازمة لإنقاذ الناس من الموت جوعاء الماتها ، من ذلك ما ذكره الإمام

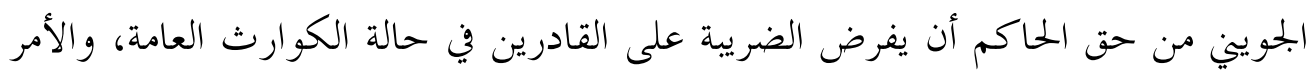

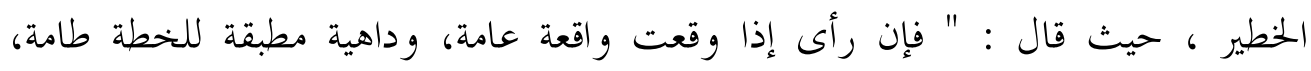
ومست الضرورات في دفاعها إلى عدة، ومادة من المال تامة ، و يد الإمام صافرة، وبيوت الأموال شاغرة؛ أن يتسبب إلى استيداء مال من موسري المؤمنين ، فإنه يفعل ذلك على لئ

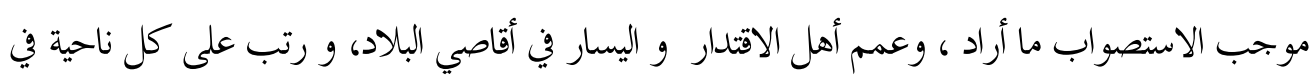

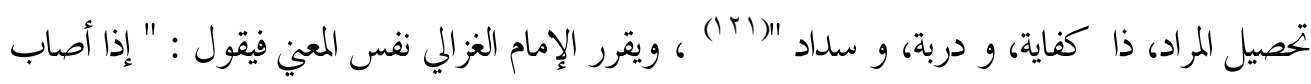

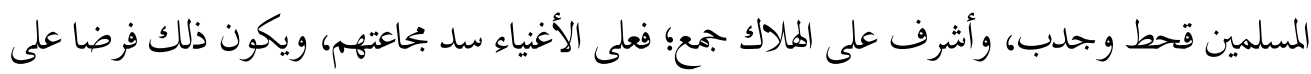

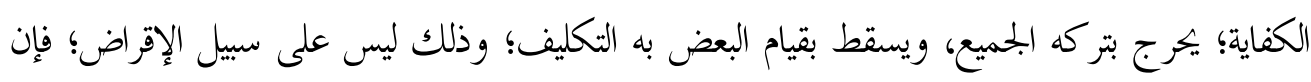
الفقراء عالة على الأغنياء، يتزلون منهم متزلة الأولاد من الآباء؛ ولا يجوز للقريب أن ينفق على قريبه

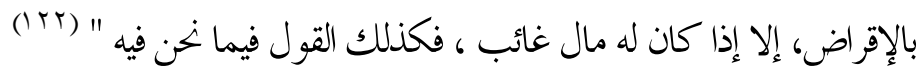
وهذا ما قرره الإمام ابن حزم بقوله : " وفرض على الأغنياء من أهل كل بلد أن يقوموا بفقرائهم، ويجبرهم السلطان على ذلك، إن لم تقم الزكوات بهم، ولا في سائر أموال المسلمين، فيقام لهم. مئا يأكلون

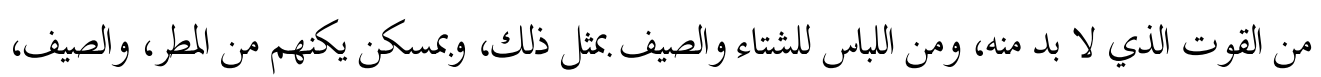
والشمس، وعيون المارة " (Tr) (IT)

و يقول الشيخ محمود شلتوت: "الأمة الممثلة في الحاكم، أو الحاكم الممثل للأمة إذا لم يجد مالا يحقق به المصالح العامة للجماعة كإنشاء دور تعليم، والاستشفاء، وتعبيد الطرق، 
وحفر الترع، و المصانع، و إعداد العدة للدفاع عن البلاد ، و وأي مع هذا أن أغنياء الأمة

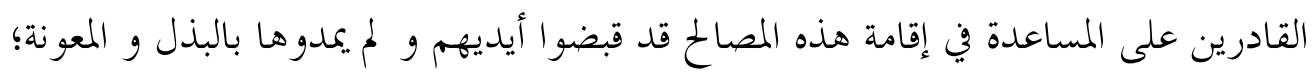

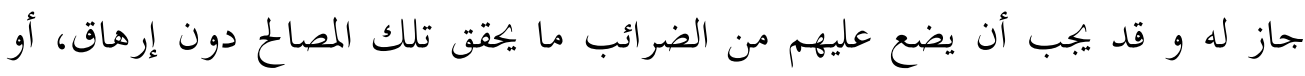
إعنات " (1) (1)

\section{المطلب الثالث : ضوابط فرض الإعاشة :}

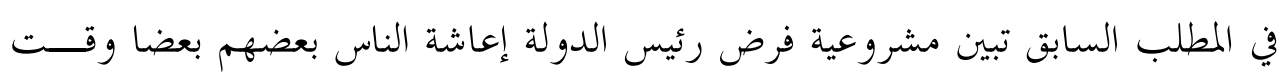

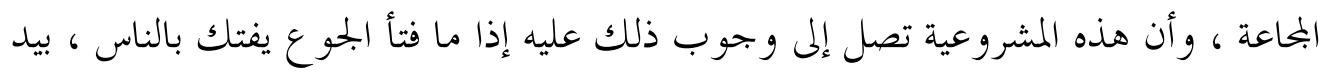

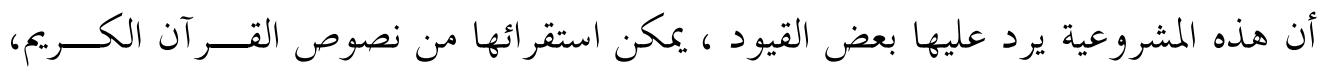

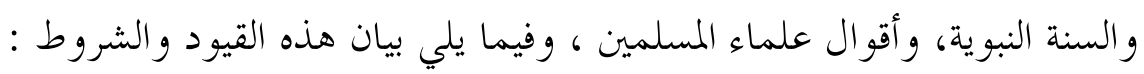

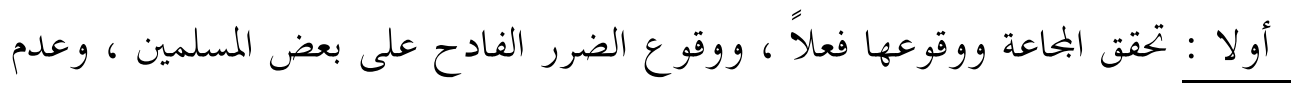

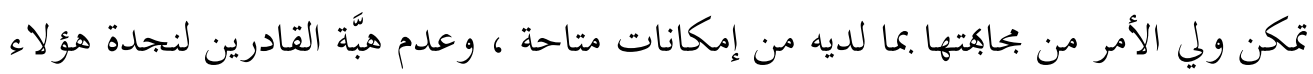

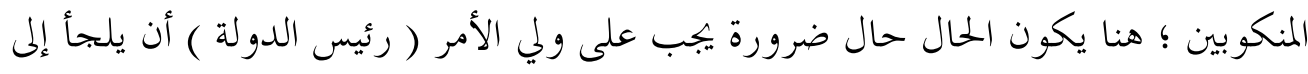

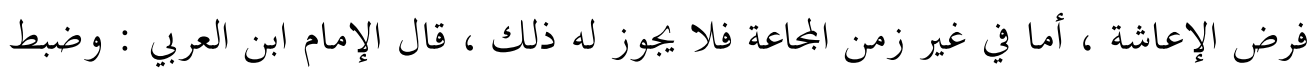

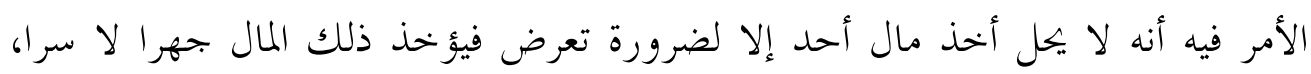

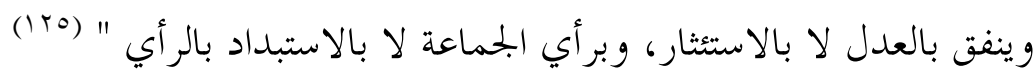

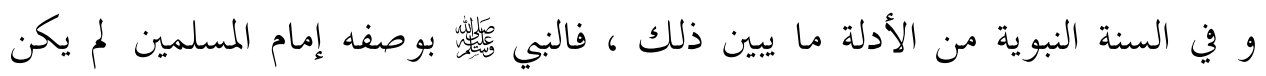

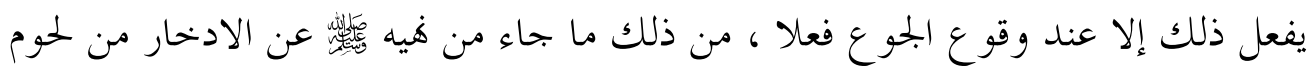

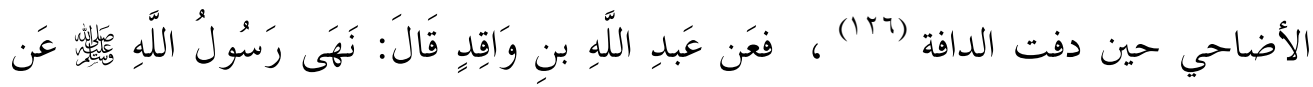

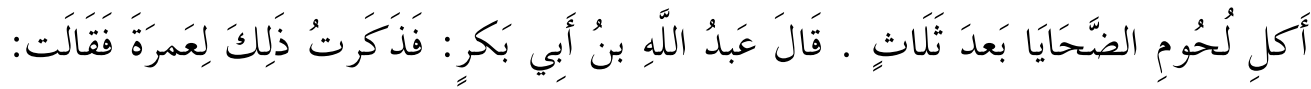

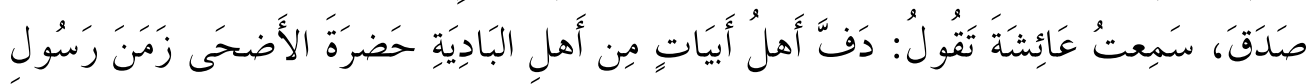
اللَّهِ

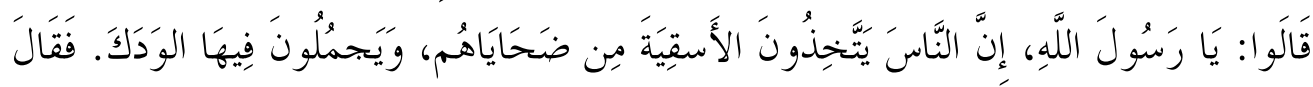

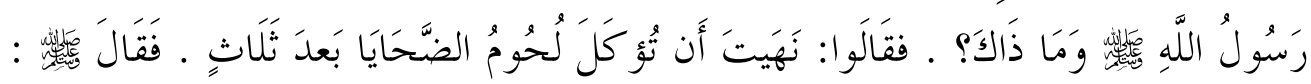

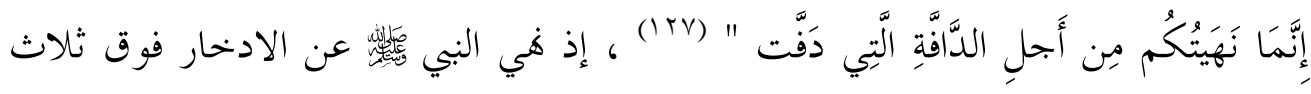


من لحوم الأضاحي لما رآه من أمر الدافة، و كان هؤلاء ناس" ضعفاء فجاؤو ادافين لضعفهم

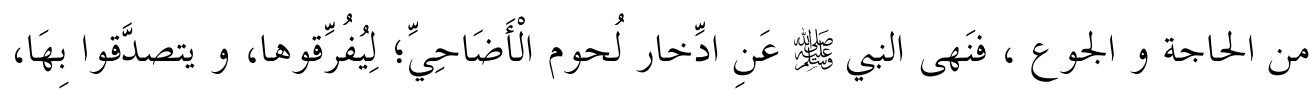

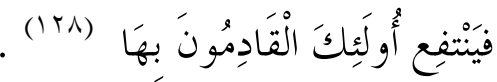

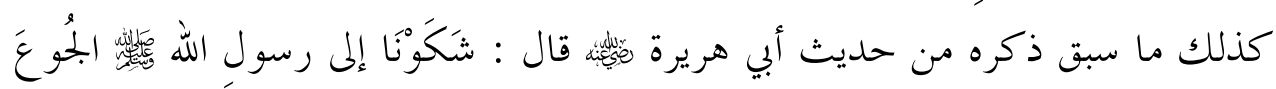

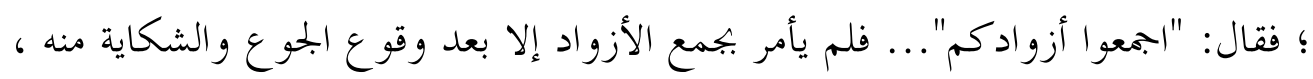
كذلك في حديث أبي عبيدة أيضا- السابق ذكره- إذ لم يأمر بجمع الأزواد إلا بعد فناء

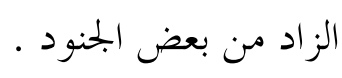

ثانيًا : ألا يكون في بيت مال المسلمين ( خزينة الدولة ) ما يفي بحل تلك المشكلة (1r9)

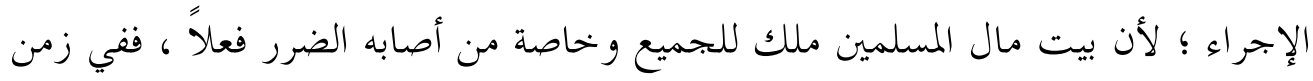

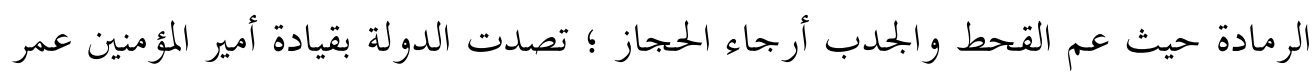

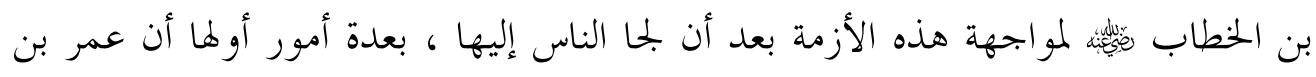

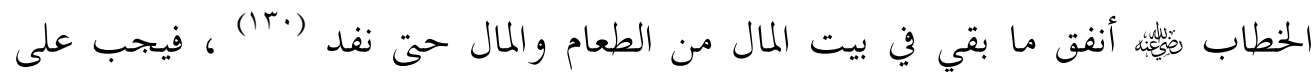
السلطان متى وقعت رعيته في ضائقة، أو حصلوا في شدة وفاقة أن يعينهم لا سيما في في

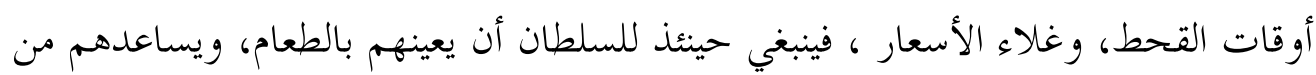

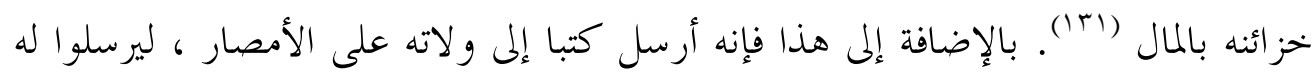
فو ائض بيت المال (Irr) وهذا القيد راجع إلى أن الأصل في المال الحرية ، وفي الذمم البراءة من التكاليف المالية ،

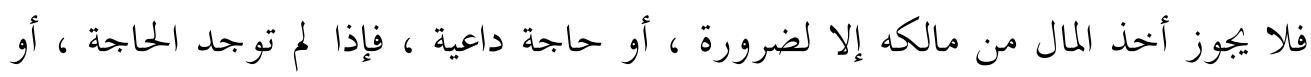
وجدات وكان هناك من الأموال أو الموارد ما يغطي نفقاها ويغني عن إلزام الناس بإعاشة

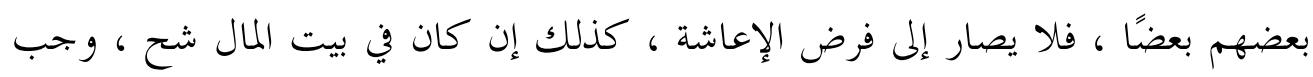
تقديم الإطعام والإعاشة ، فاعتبار الأولوية يوجب توجيه المال إلى الأهم ، وليس هناك أهم

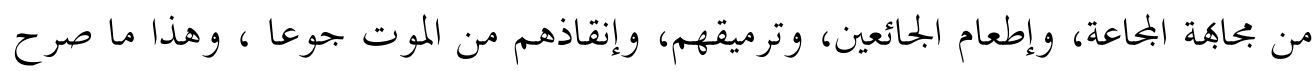

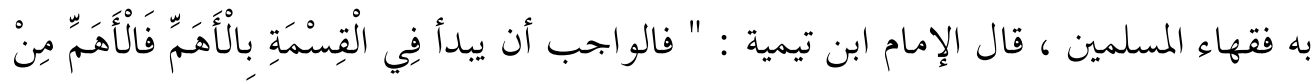




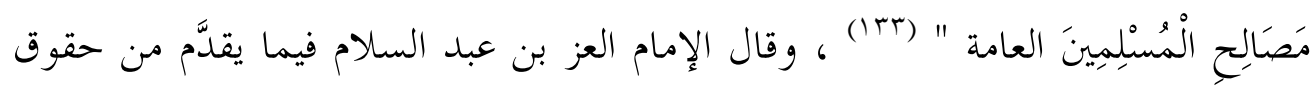

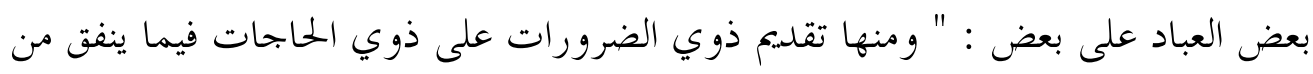

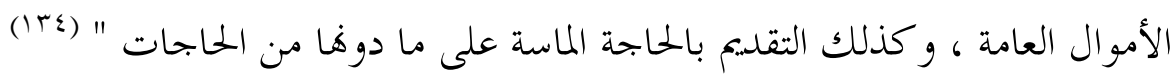

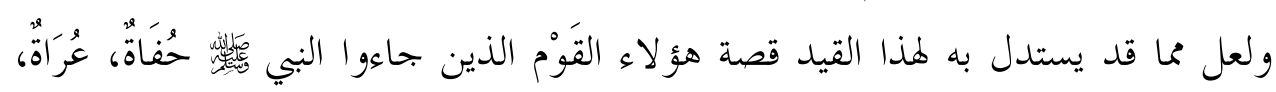

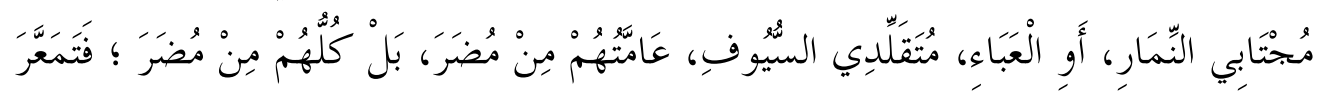

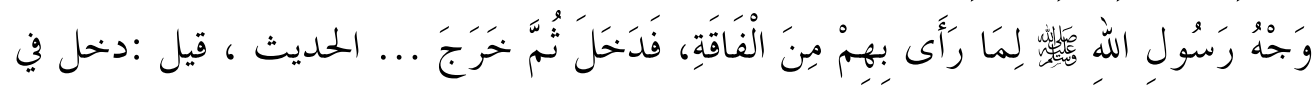

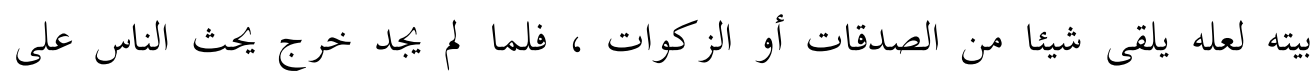

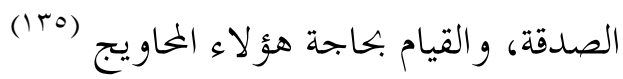

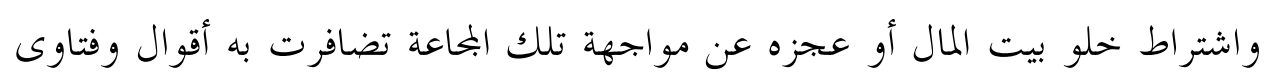

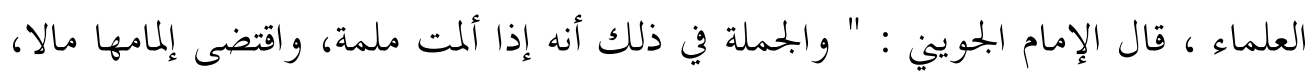

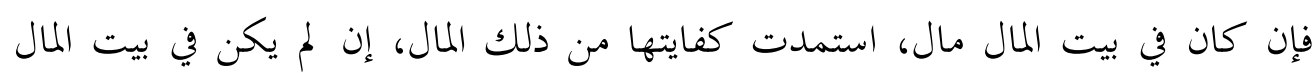

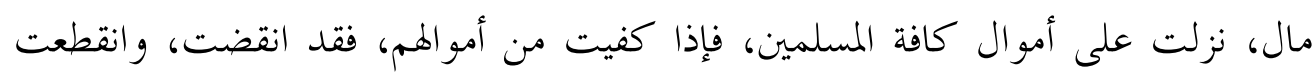

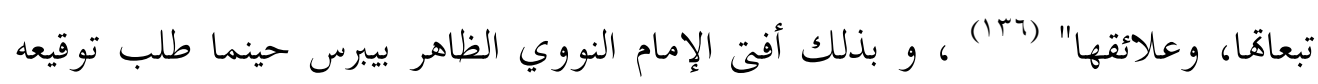

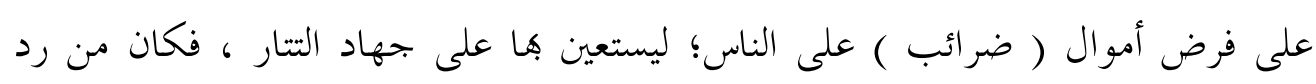

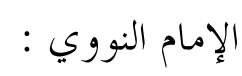

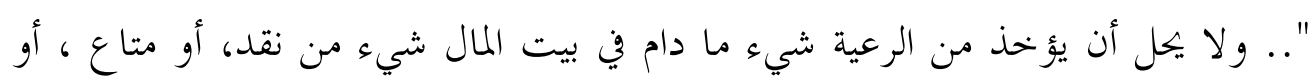

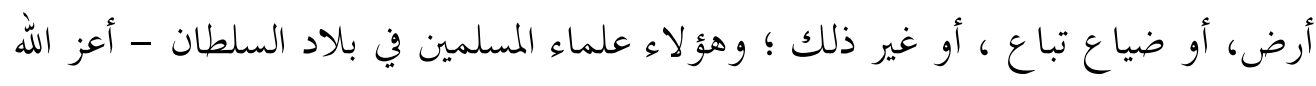

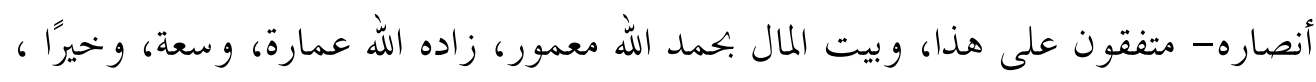

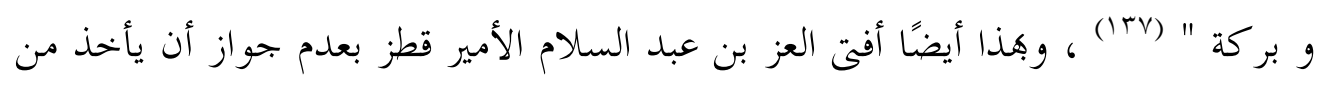

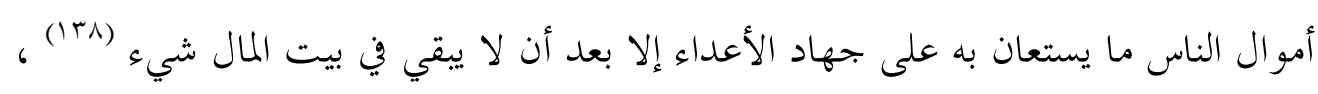

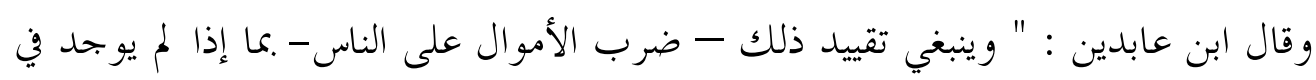

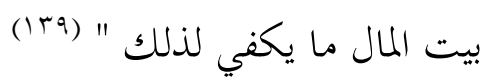


هذا وقد اختلف العلماء فيما إذا خلا بيت المال واحتاج الإمام إلي المال في حرب أو بجاهة كارثة هل يأخذ من الناس ويكون ذلك على سبيل القرض على بيت المال يجب رده

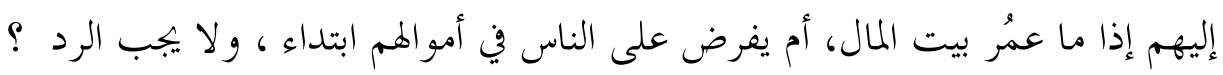

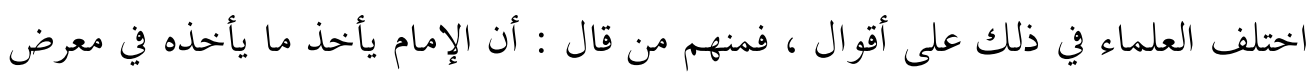

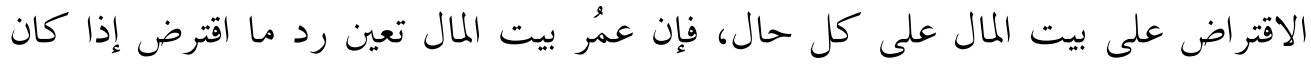

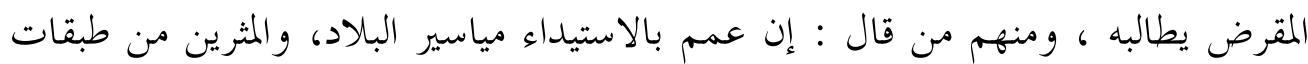

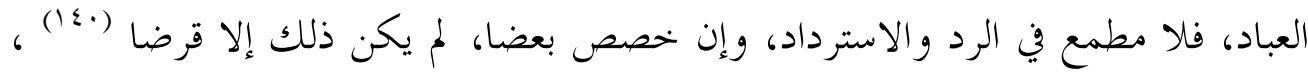

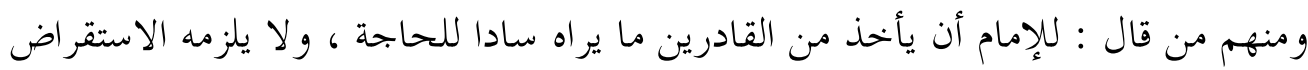

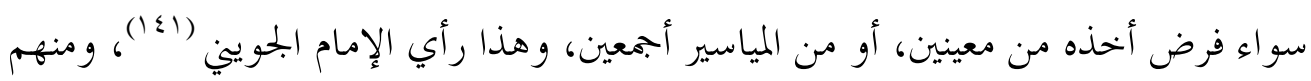

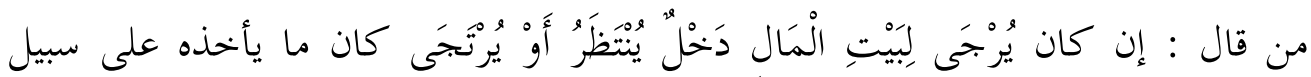

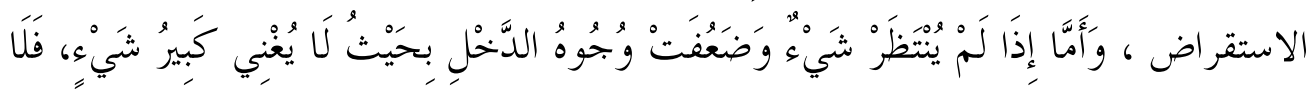

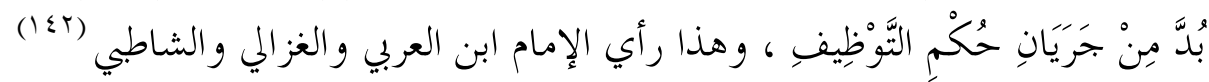

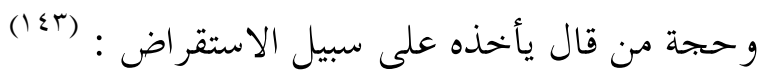

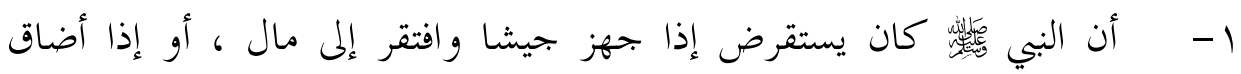

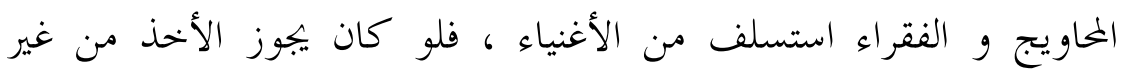

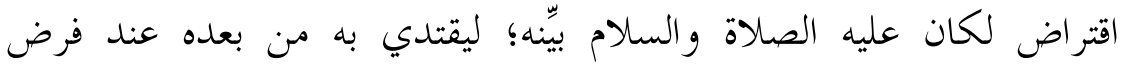

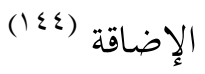

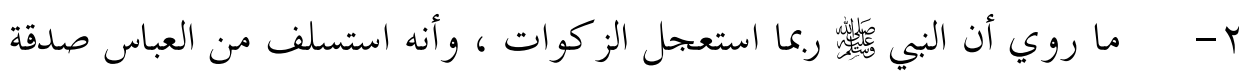

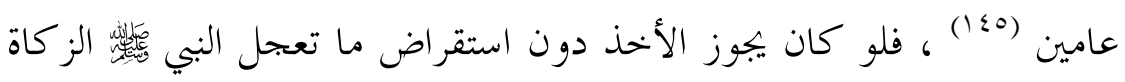
لعامين قادمين . لع. r- - أقدار الواجبات في أموال الناس مضبوطة الجهات في قواعد الدين، ومذاهب المسلمين ، فلا يزاد عليها بوجه من الوجوه . ع - مآحذ الأموال لو تعدت الطرق المضبوطة، والمسالك الموضحة في الشريعة، لانبسطت الأيدي إلى الأموال، ويجر ذلك فنونا من الخبال، و لم يثق ذو مال 
ماله، لا في حاله، ولا في مآله، وهذا خروج عن ضبط الدين، وحل لعصام

$$
\text { الإسلام عن أمو ال المسلمين. }
$$

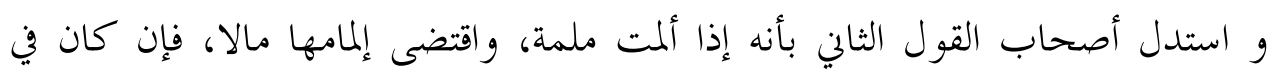
بيت المال مال، استمدت كفايتها من ذلك المال، وإن لم يكن في بيت المال مال، نزلت على أموال كافة المسلمين، فإذا كفيت من أموالهم، فقد انقضت، و وانقطعت تبعاها، وعلائقها، فإذا حدث مال، هيأ ما حدث للحو ادث المستقبلة ، و لو فرضنا خلو الزمان عن مان مطاع، لوجب على المكلفين القيام بفرائض الكفايات، من غير أن يرتقبوا مرجعا، فإذا وليهم إمام فكأفم ولوه أن يدبرهم تعيينا وتبيينا، فيما كان فرضا بينهم فرضى، ولولان لاه

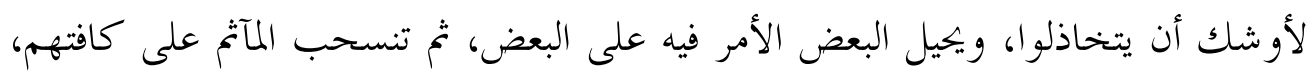

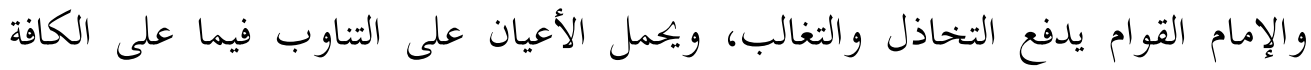
الخروج عن عهدته، والذي يوضح المقصد أنه لو استقرض، لكان يؤدي ما اقترضه من مال فاضل مستغنى عنه في بيت المال، ور.ما تمس الحاجة إلى ما يقدره في الحال فاضلا، ثم يقتضي لمالي

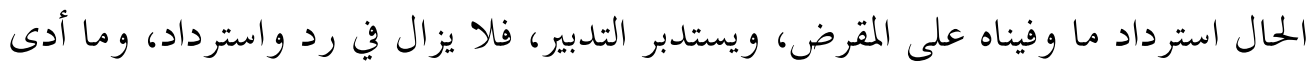

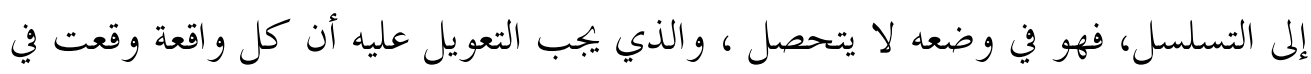

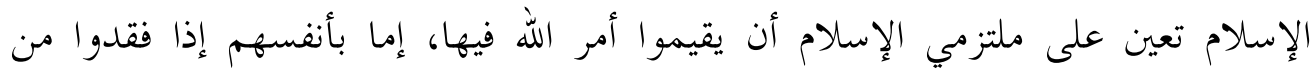

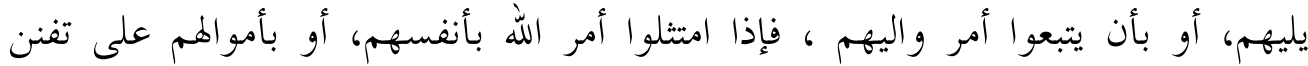

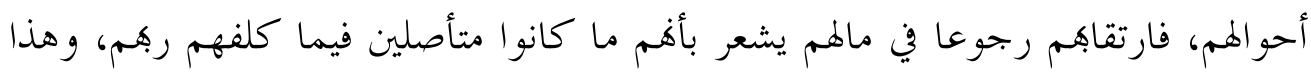

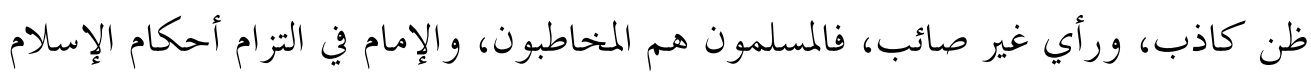

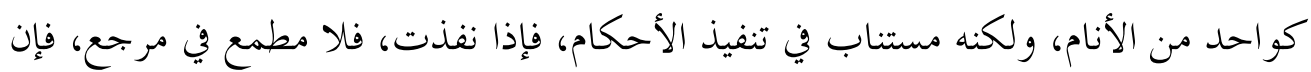

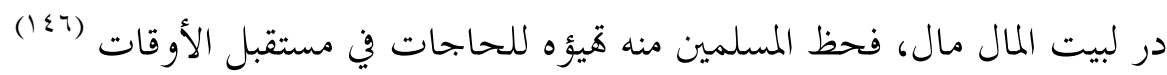

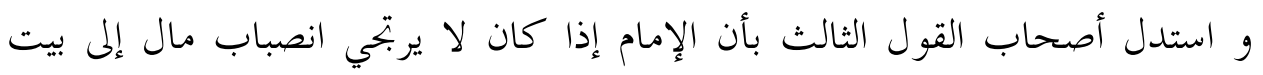
المال، يزيد على مؤن العسكر ونفقات المرتزقة في الاستقبال؛ فعلى ماذا الاتكال في الاستقراض مع خلو اليد في الحال، و انقطاع الأمل في المآل؟ نعم : لو كان له ماله لهال غائب، أو جهة معلومة تحري بحرى الكائن الموثوق به، فالاستقراض أولى، ويتزل ذلك متزلة المسلم 
الواحد إذا اضطر - في غخمصة - إلى الهلاك، فعلى الغنى أن يسد رمقه، وييذل من ماله ما

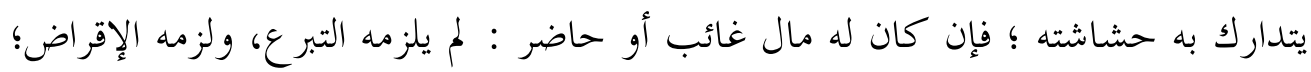

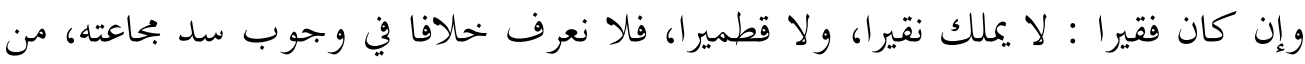

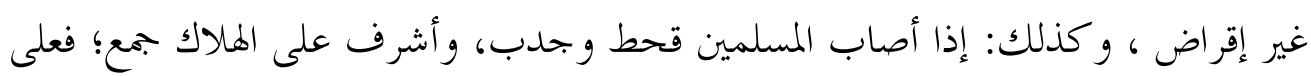

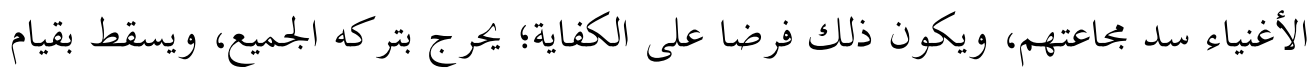
البعض به التكليف؛ وذلك ليس على سبيل الإفراض؛ فإن الفقراء عالة على الأغنياء، يتزلون

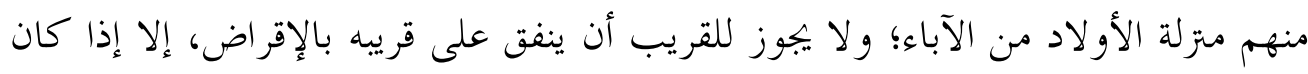

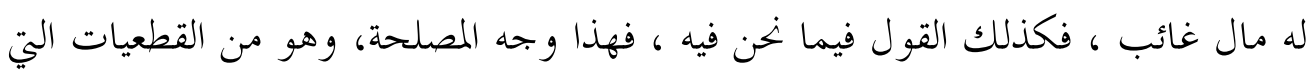

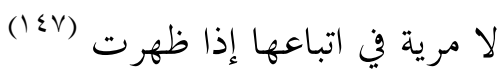

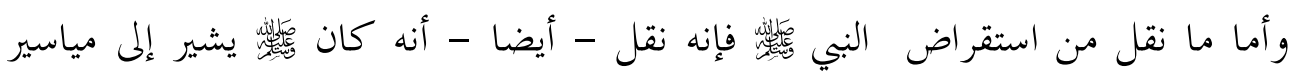

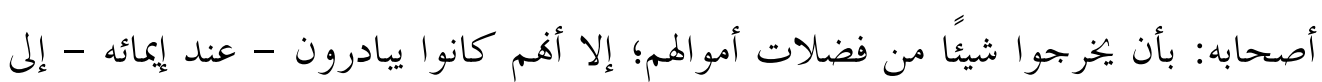

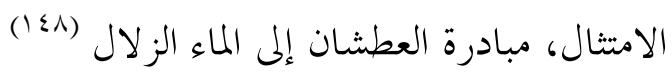

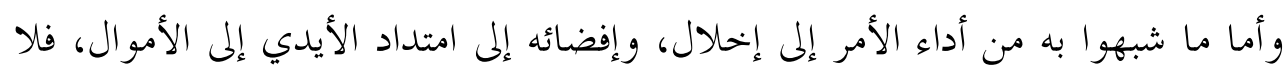

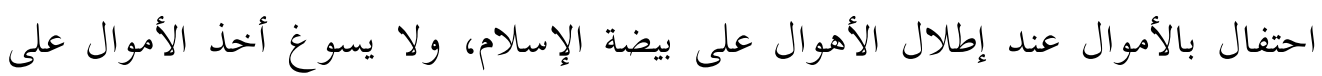

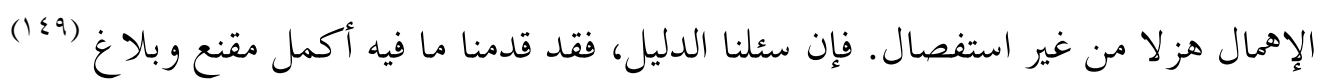

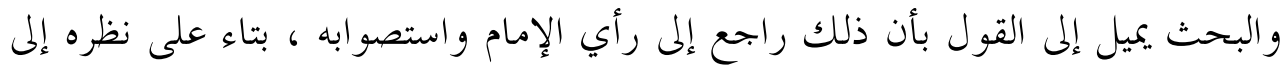

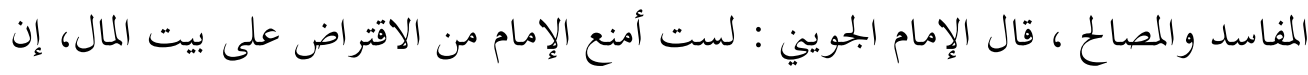

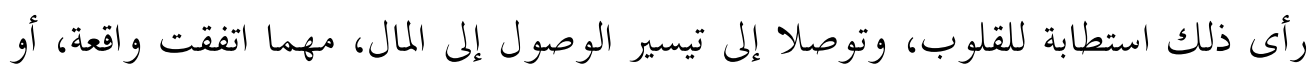

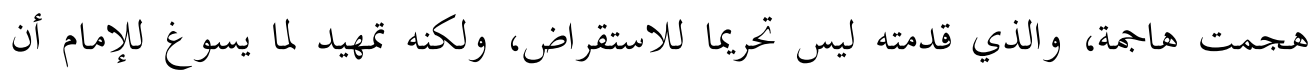

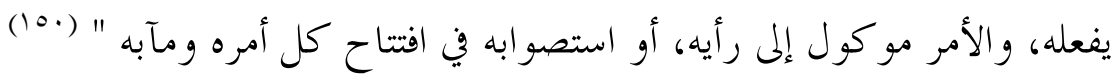

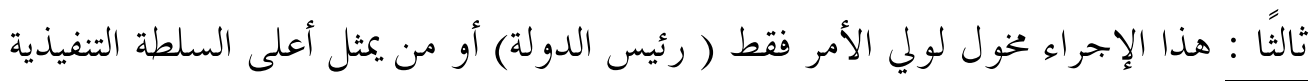

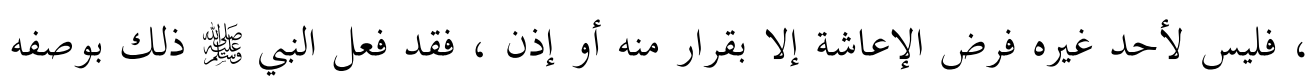

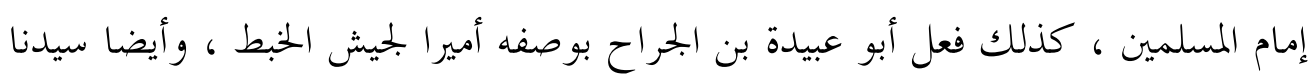

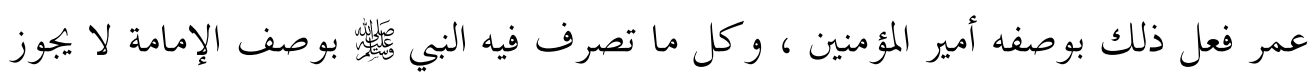




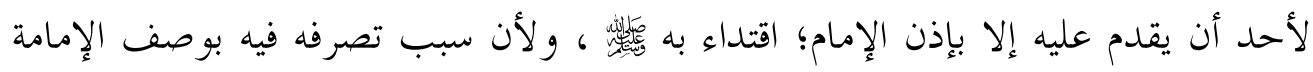
دون التبليغ يقتضي ذلك ، فبعث الجيوش لقتال الكفار، والحوارج ومن تعين قتاله، وصرف

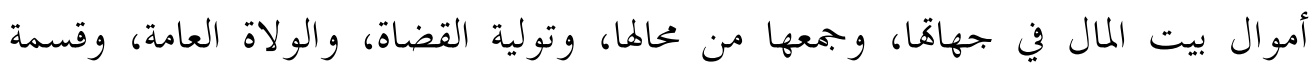

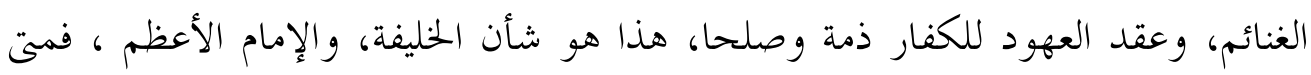

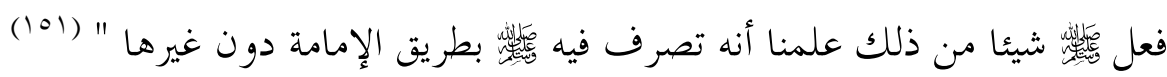

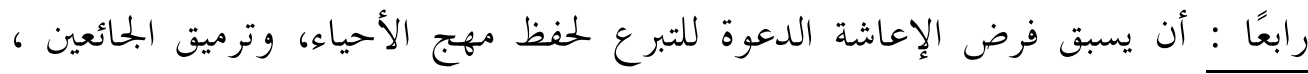
وتدارك حشاشة الفقراء ، وقد كان البي لئل

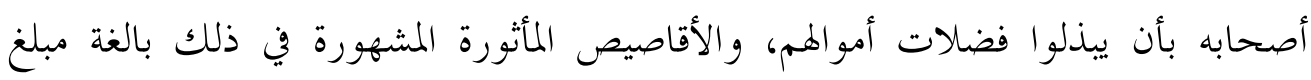
التواتر (10r) ، فيبدأ ولي الأمر .مخاطبة الموسرين والقادرين علي الإعاشة، و كذا الراغبين

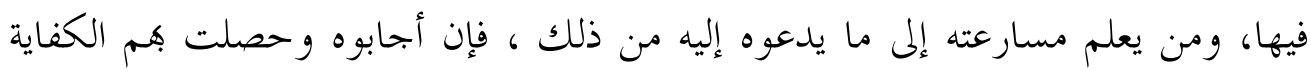

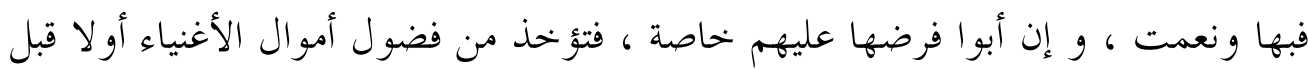
غيرهم ، فإن لم تحصل همم الكفاية عمم فرضها علي الجميع حتى وإن طال من يشبعون

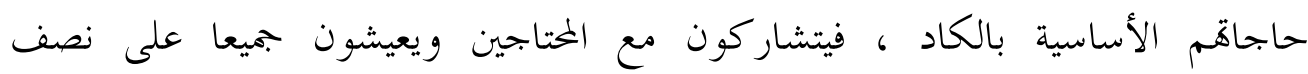
احتياجاهم الأساسية ، وقد ذكر مسلم في حديث جابر: " طعام الواحد كافي الاثنين،

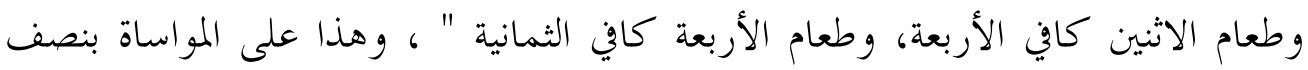

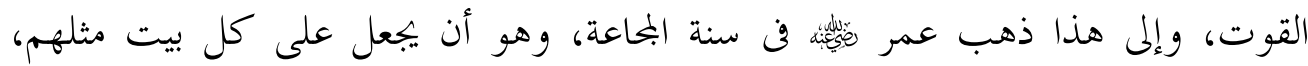

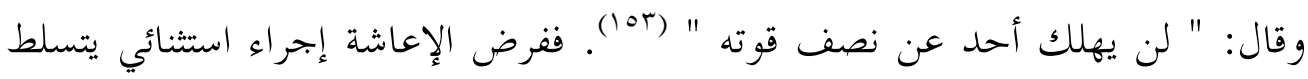

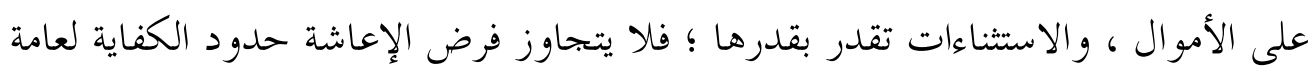
الناس قبل البدء بفضول الأموال .

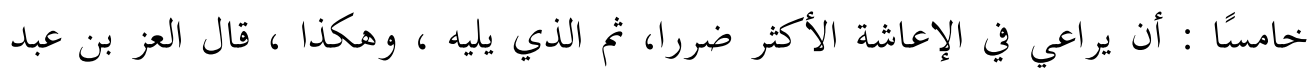

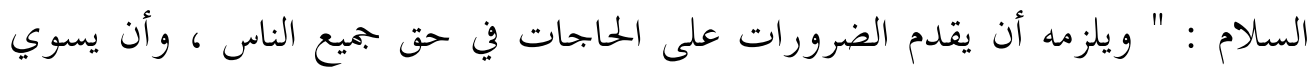
بينهم في تقديم أضرهم فأضرهم، وأمسهم حاجة فأمسهم، والتسوية بينهم ليست من

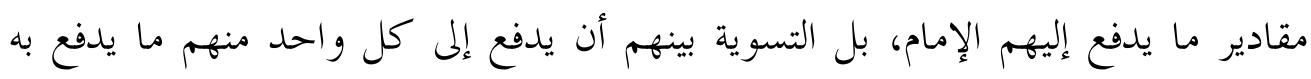

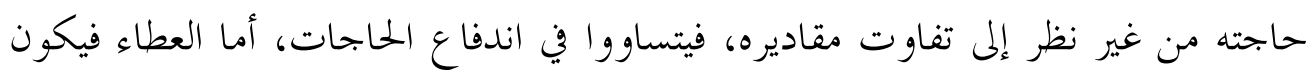


على قدر الحاجات(1)") قال العز : " تقدير النفقات بالحاجات مع تفاوها عدل وتسوية "

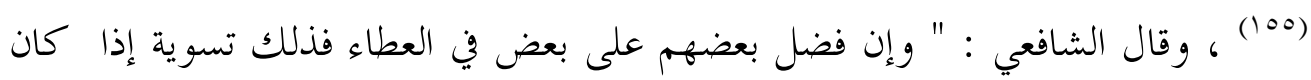

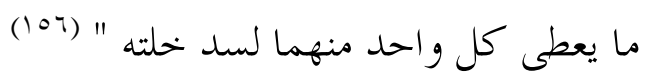

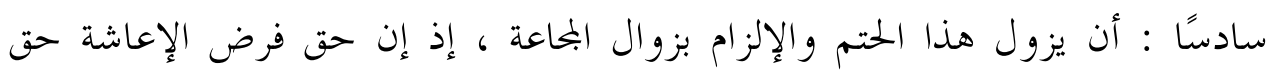

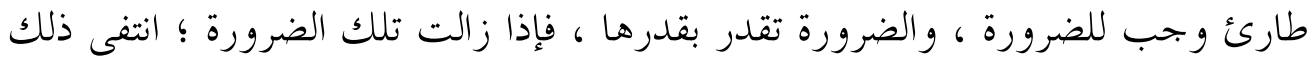

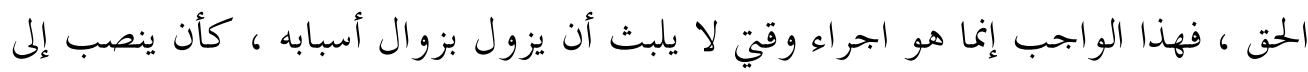

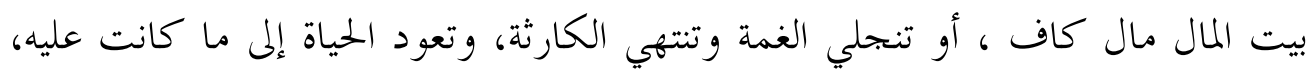
ويتوفر الطعام والشراب، ويصير .بمتناول الجميع العمل والاكتساب ، وهذا يفهم من قصة

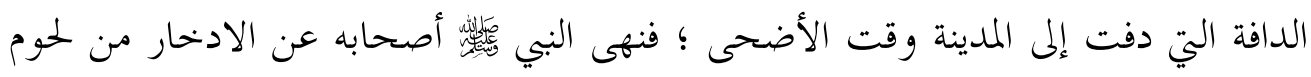
الأضاحي فوق ثلاث ليال ؛ ليبقى من الأضاحي ما يسد جوعة هؤلاء الدافة ، فلما كان

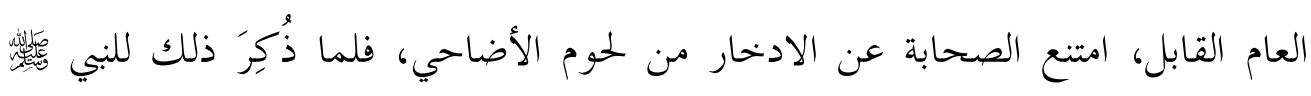

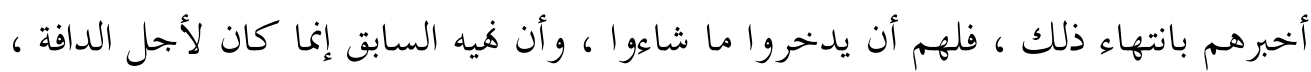

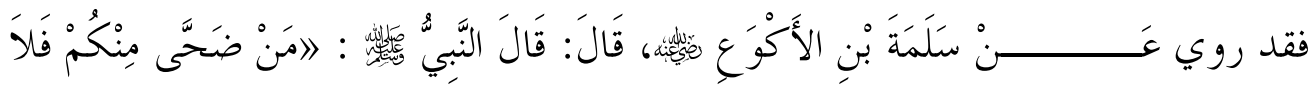

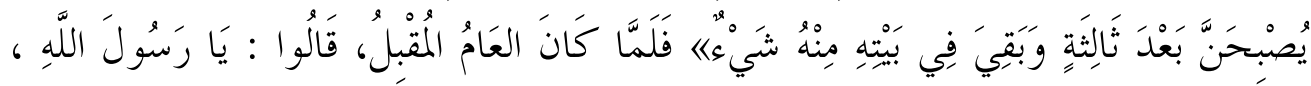

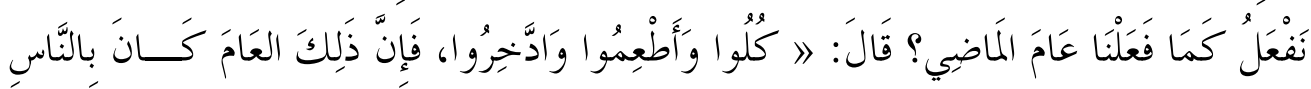

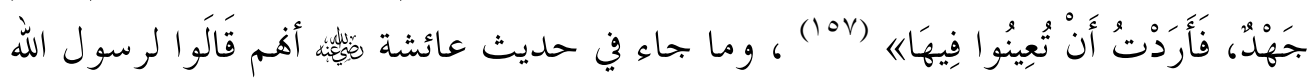

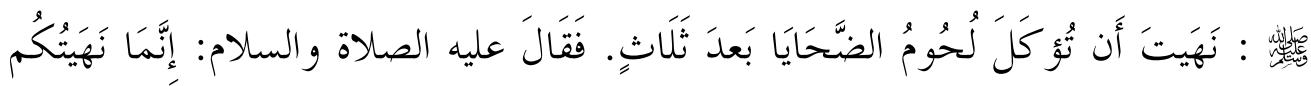

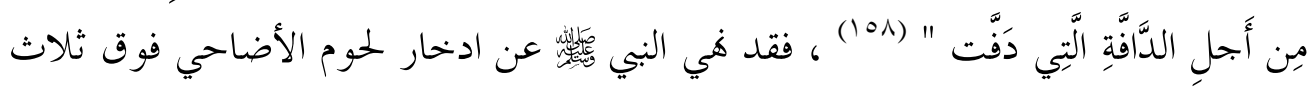

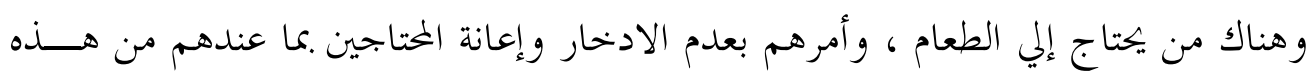

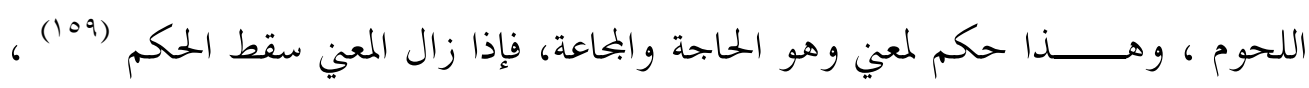
فقد أعلمهم البي لِي

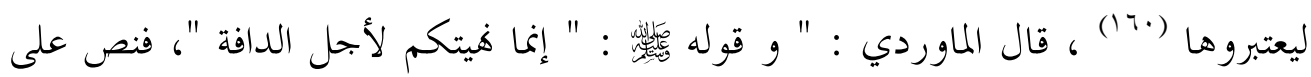

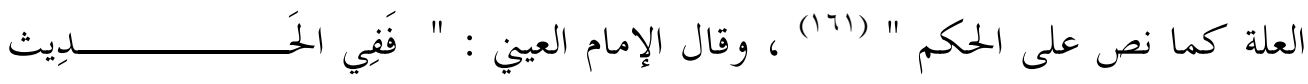

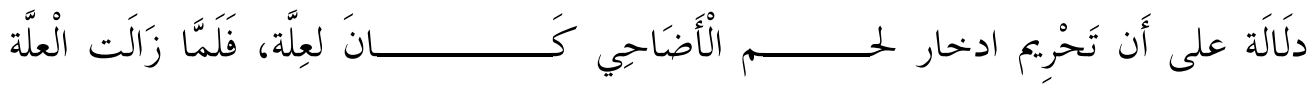




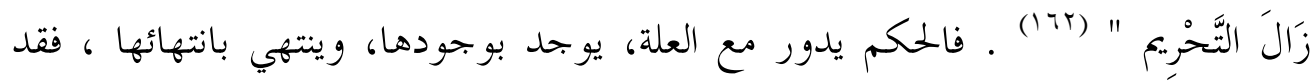

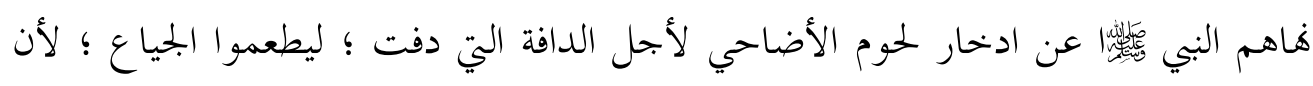

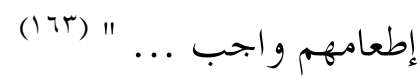
سابعا : العدل في فرض الإعاشة والإلزام ها ، و ولا يقصد بالعدل "المساواة" ؛ لأن المساواة

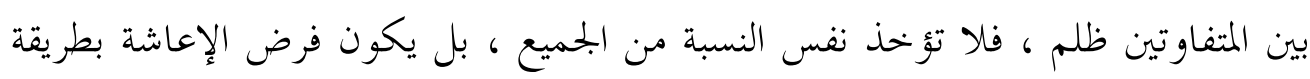

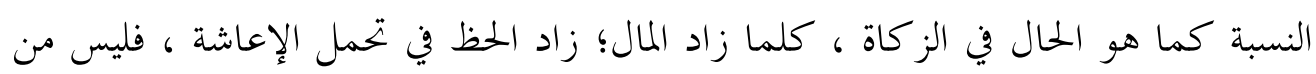

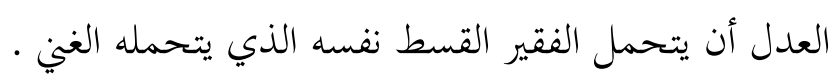

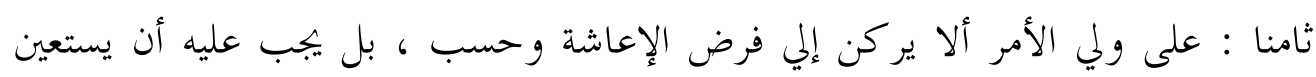

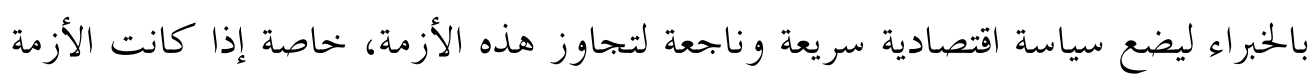

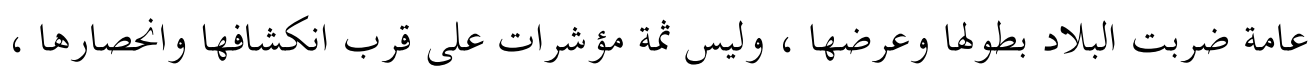

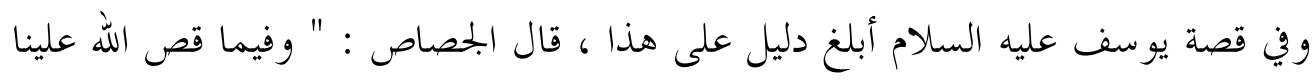

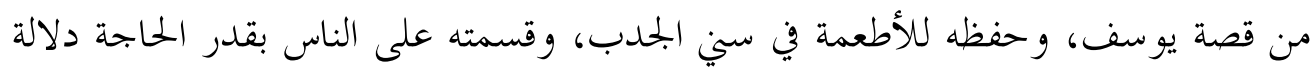

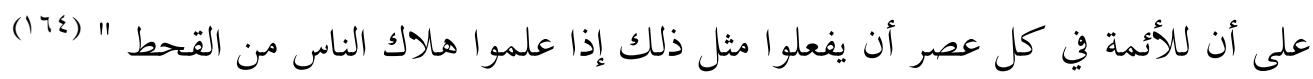

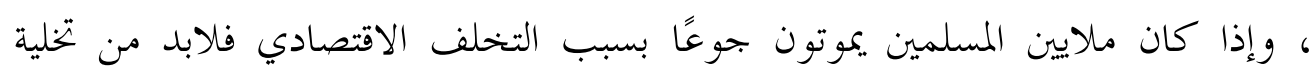

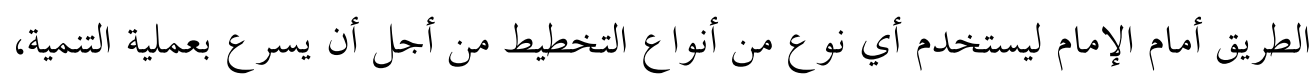

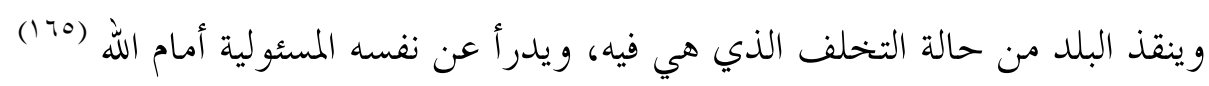

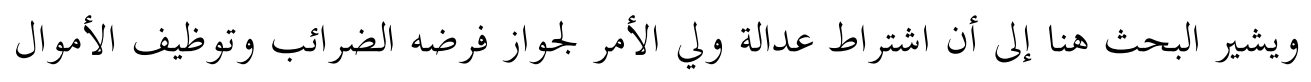

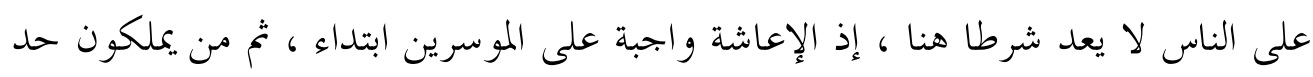

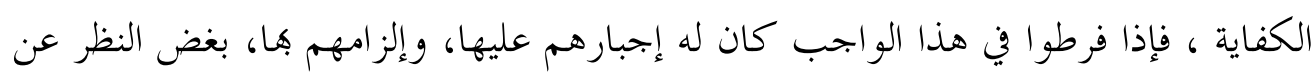

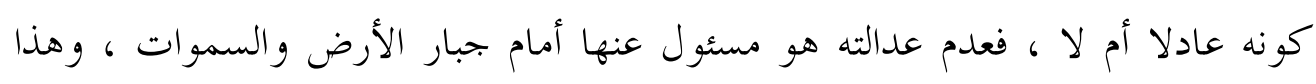

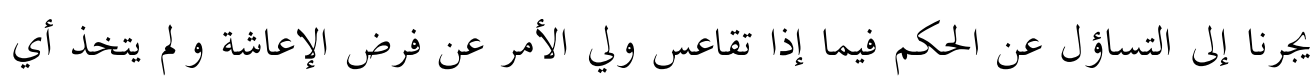

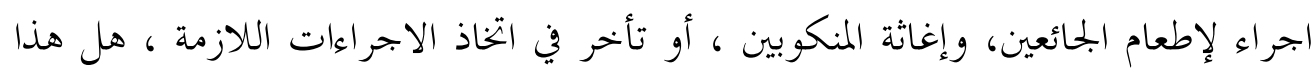

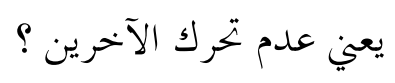


و الجو اب بالنفي قطعا ، إذ سد خلات المضطرين واجب على من علم بحالهم من الموسرين

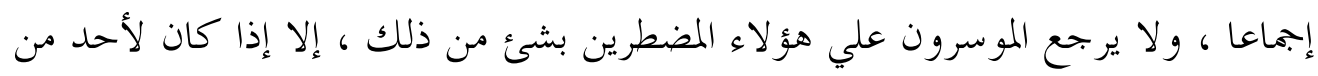

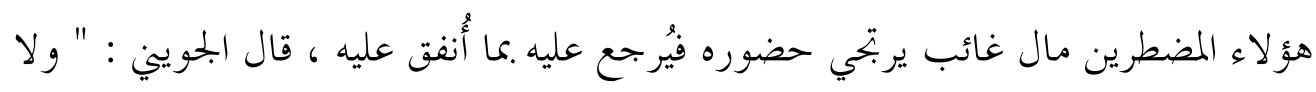

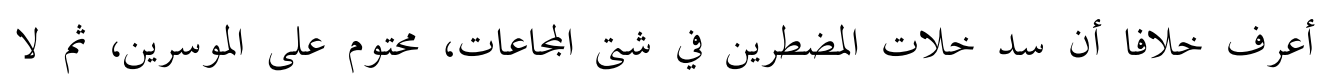

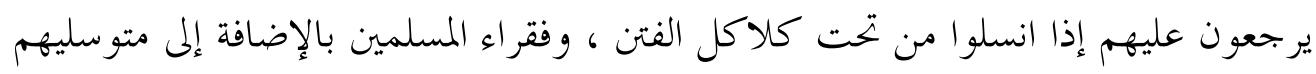

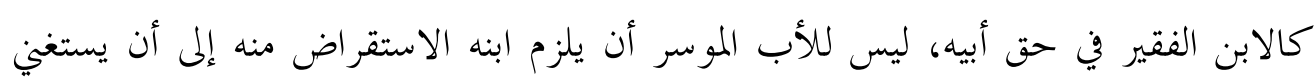

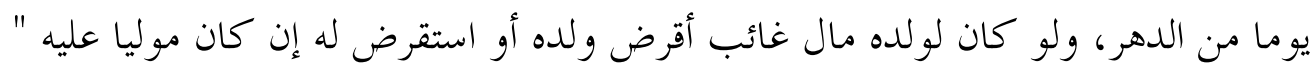

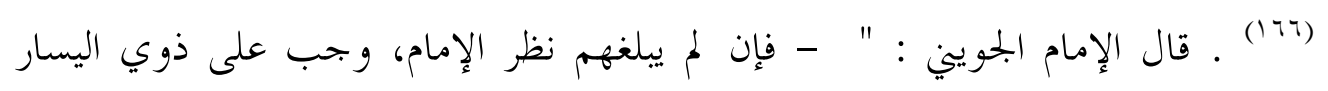

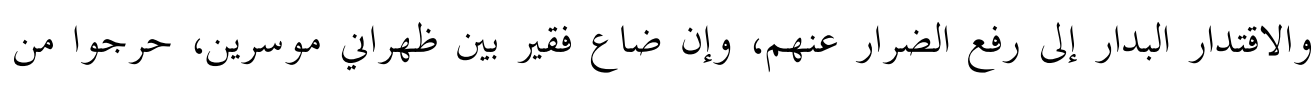

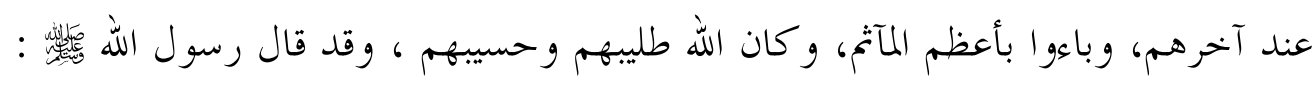

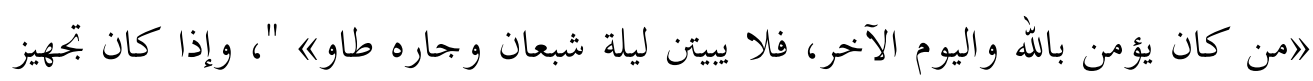

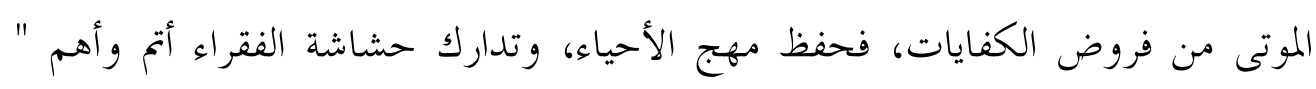

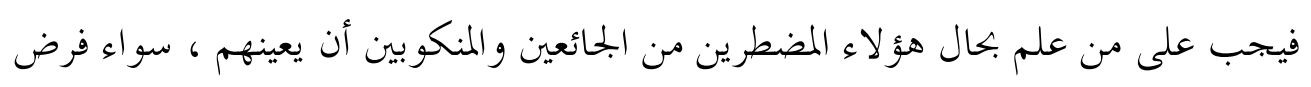

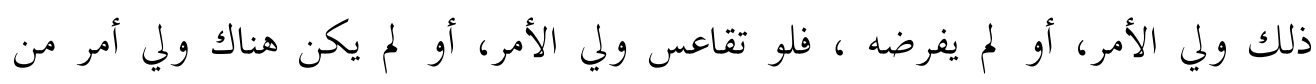

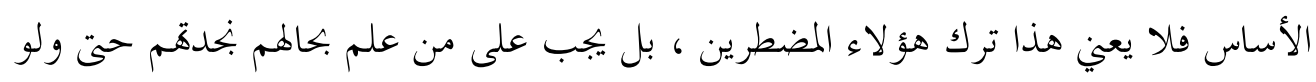

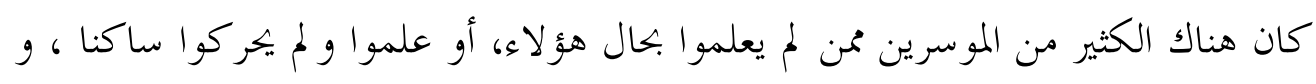

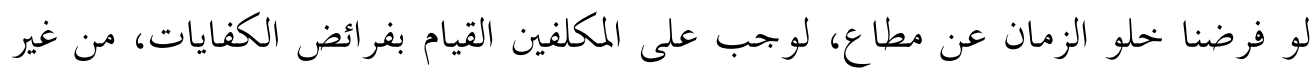

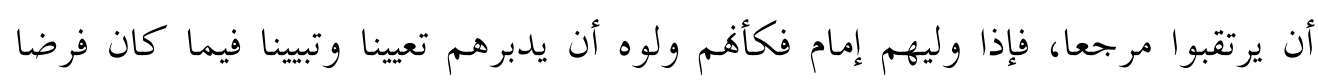

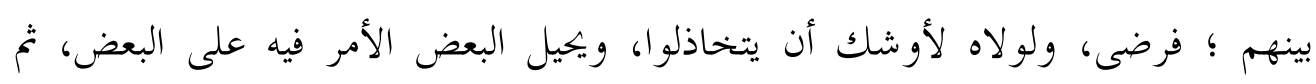

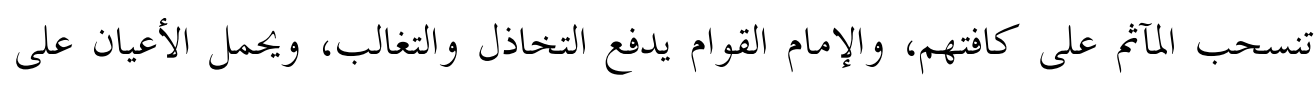

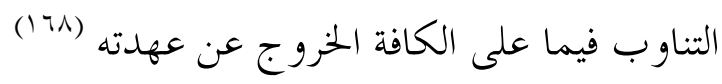


وقال القاضي ابن العربي مبينا الحال فيما إذا منع ولي الأمر توزيع الز كاة على مستحقيها

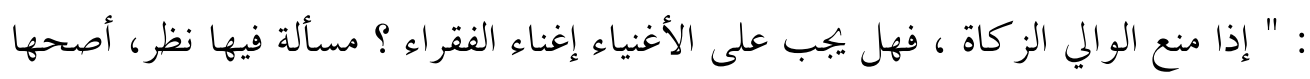

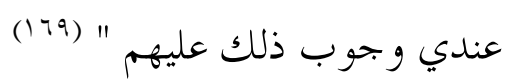

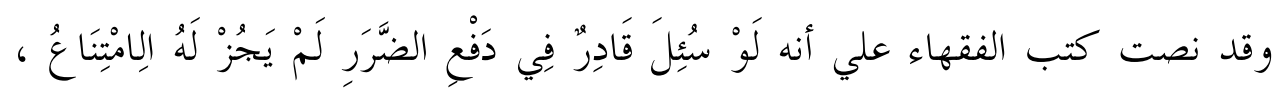

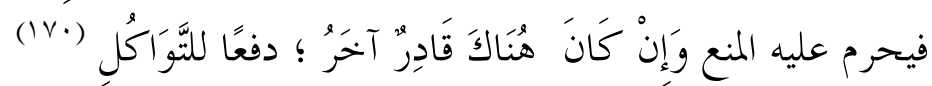

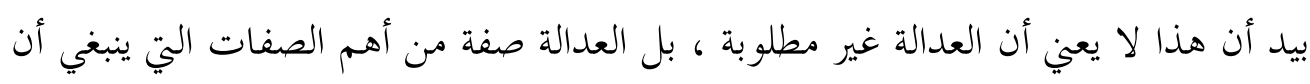

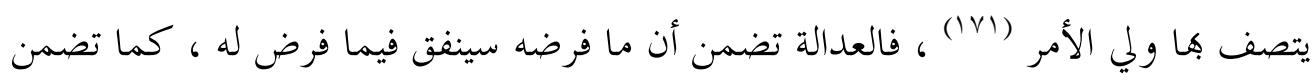

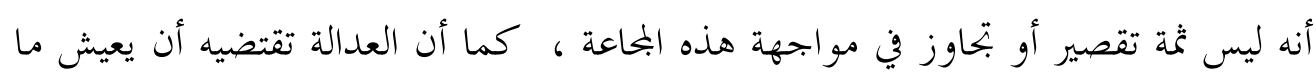

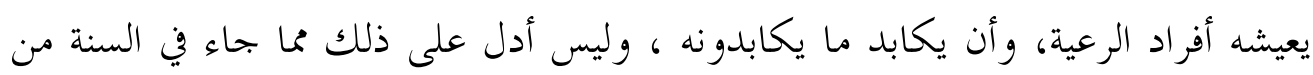

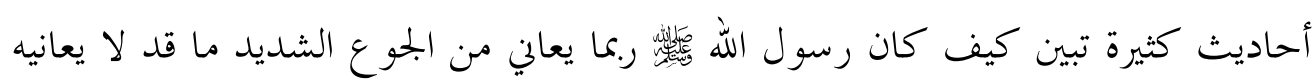

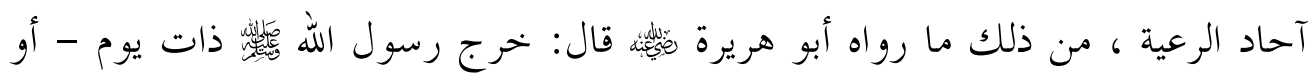

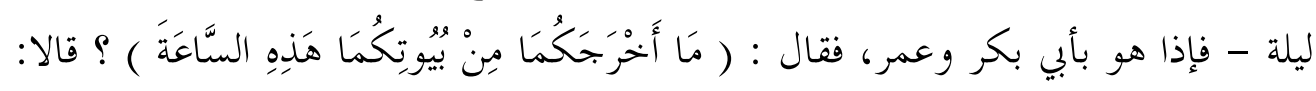

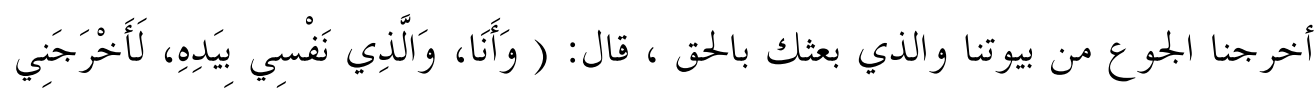

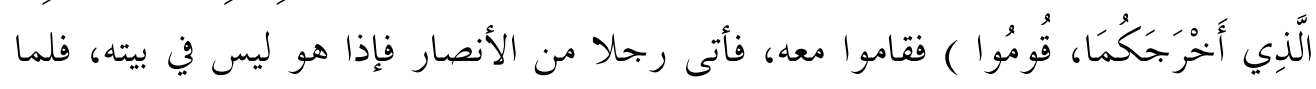

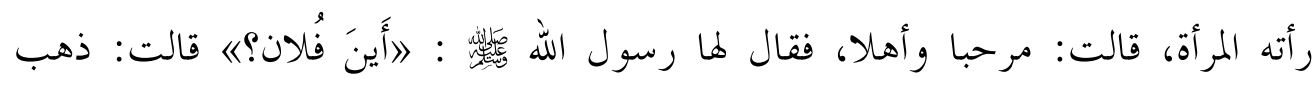

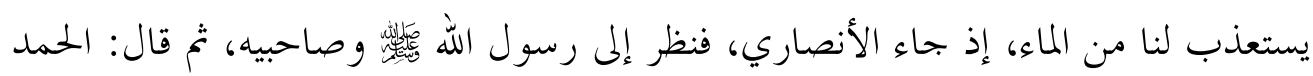

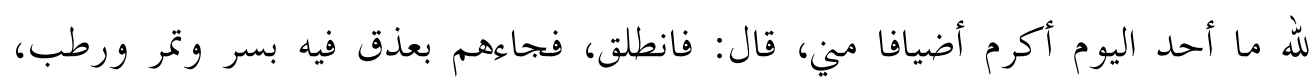

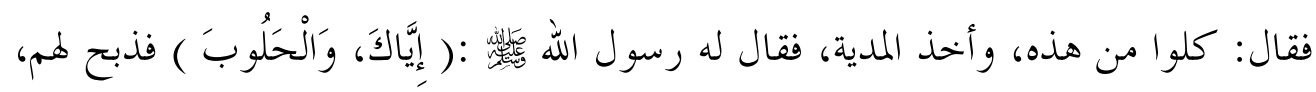

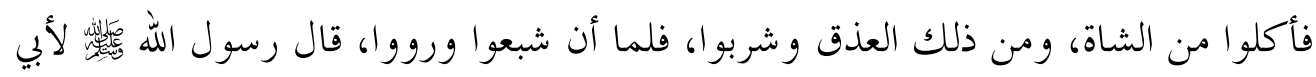

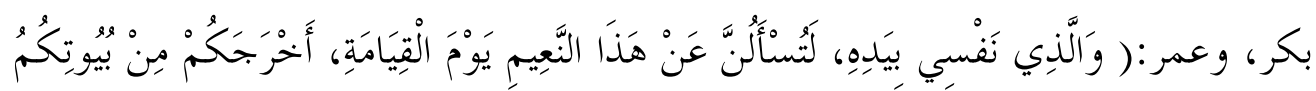

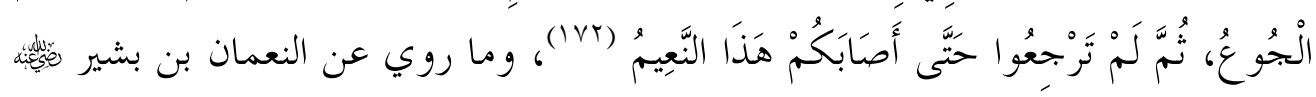

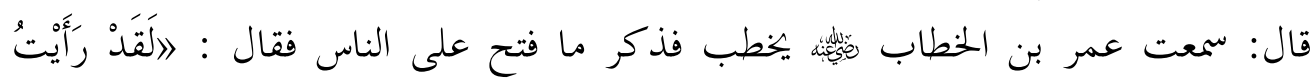

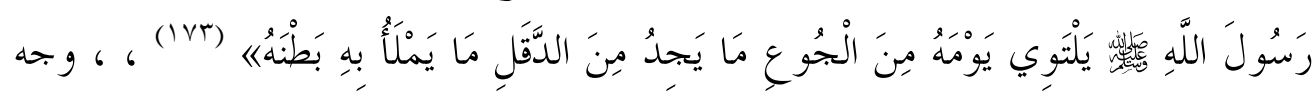




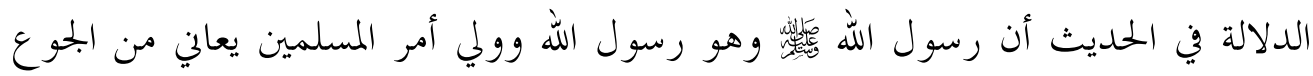

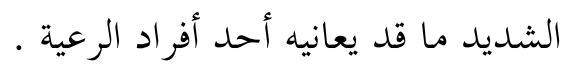

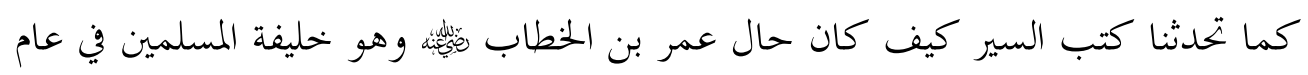

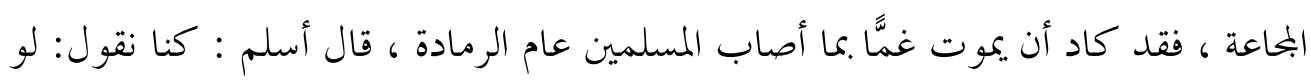

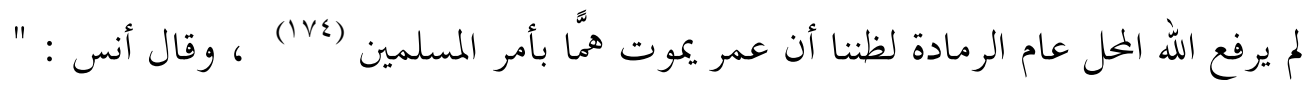

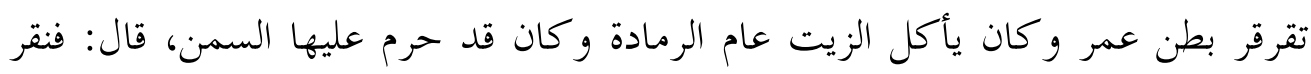

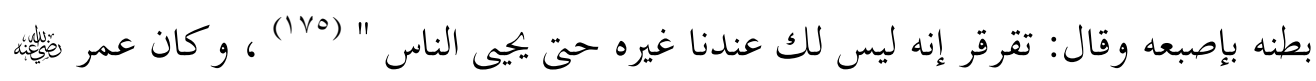

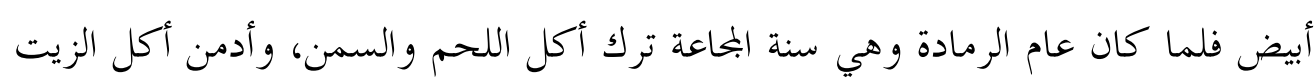

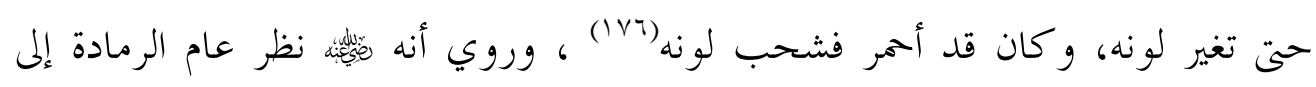

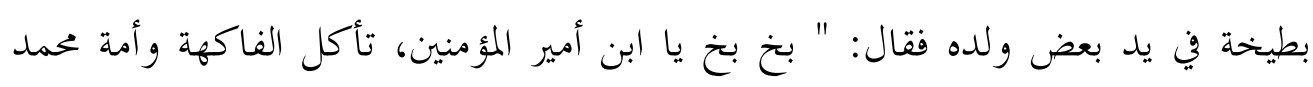

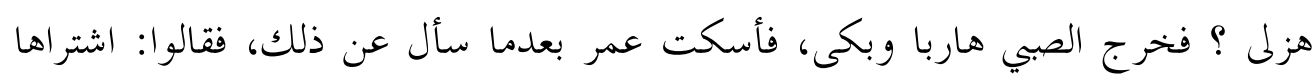

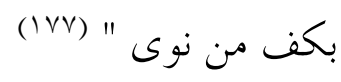

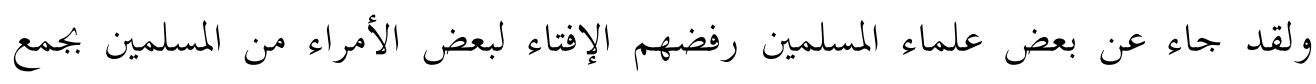

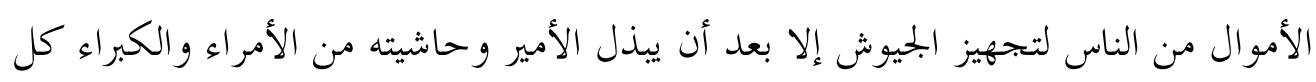

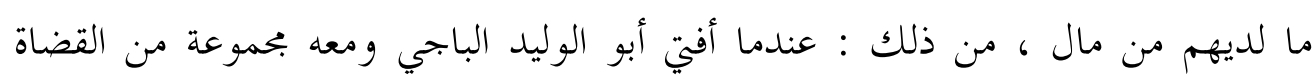

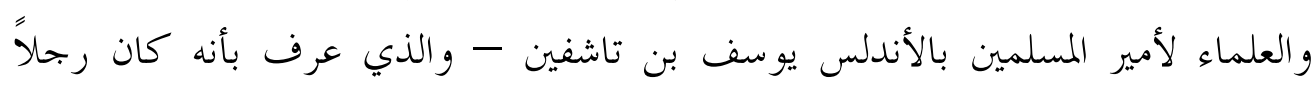

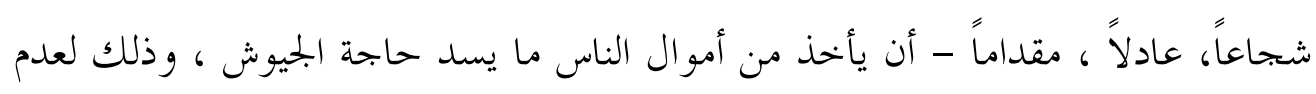

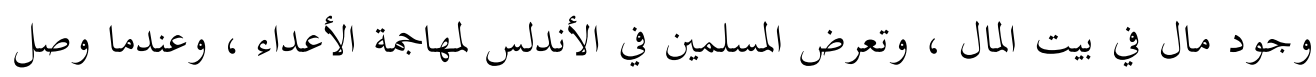

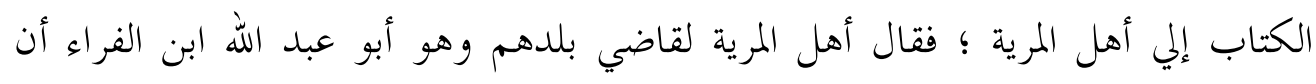

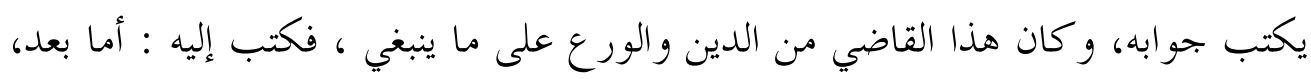

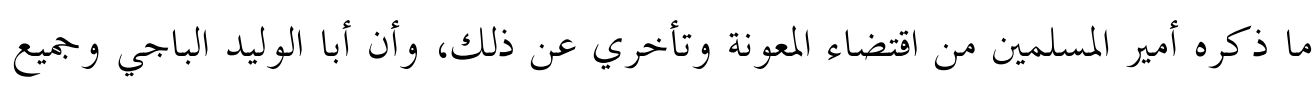

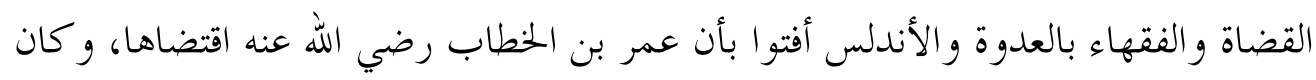

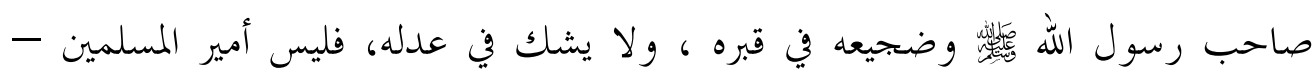

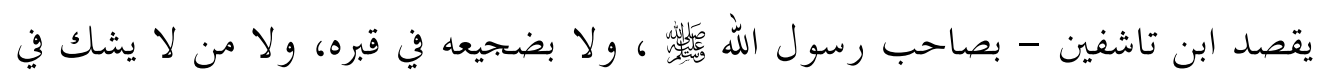


عدله، فإن كان الفقهاء والقضاة أنزلوك بمتزلته في العدل فالله سائلهم عن تقلدهم فيك ،

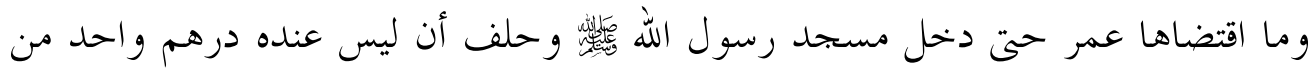

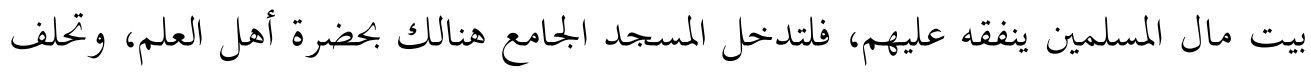
أن ليس عندك درهم و احد، ولا في بيت مال المسلمين، وحينئذ تستوجب ذلكن، ولك، والسلام (IVA)

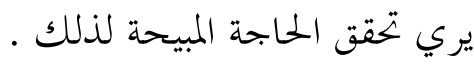
ومن ذلك أيضًا قول العز بن عبد السلام للأمير قطز عندما جمع القضاة، والفقهاء،

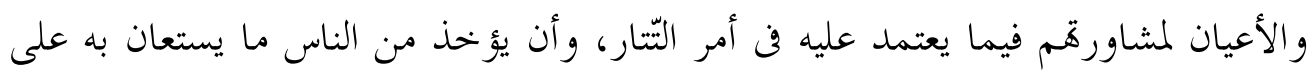

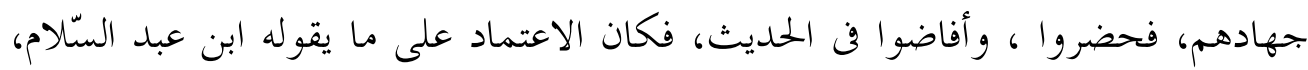

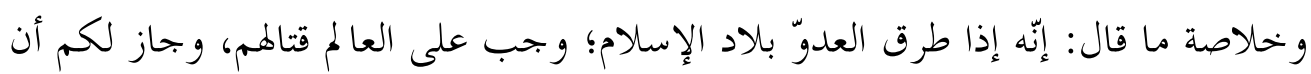

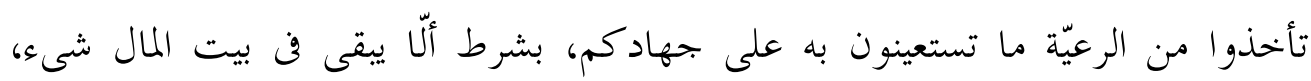

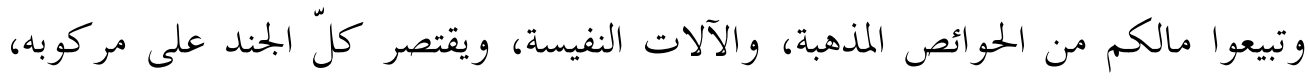

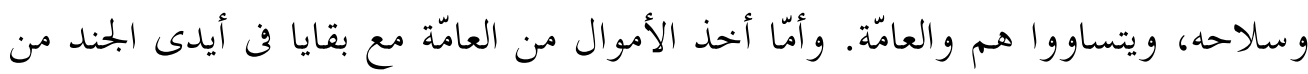

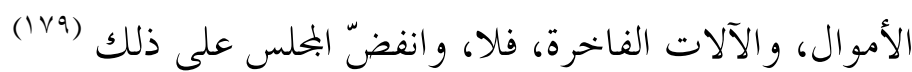

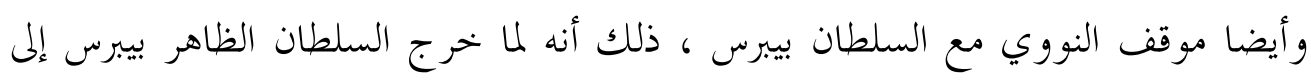

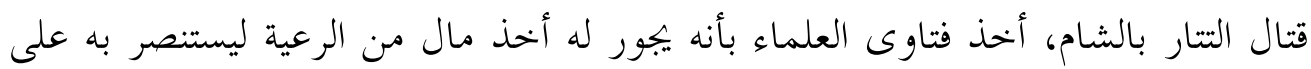
قتال العدو، فكتب له فقهاء الشام بذلك، فقال: هل بقي أحد؟ فقيل: نعم، بقي الشيخ

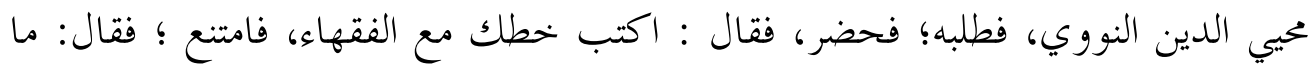
سبب امتناعك؟ فقال: أنا أعرف أنك كنت في الرق للأمير بندقدار ، وليس لك مال، ثم

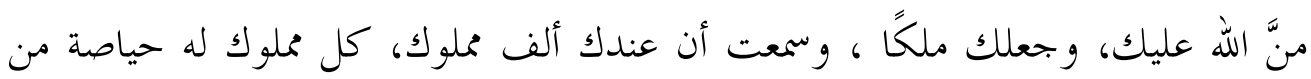

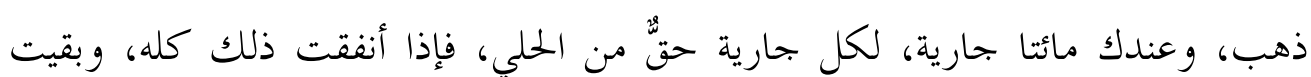

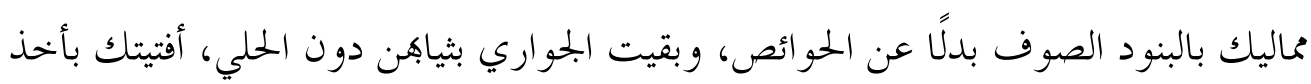

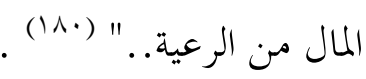


على أنه ينبغي التفريق هنا بين مال الحاكم الخاص به الذي كان تملكه قبل توليه الحكم

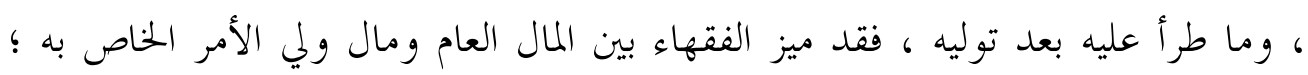

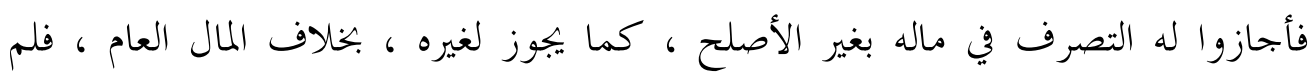

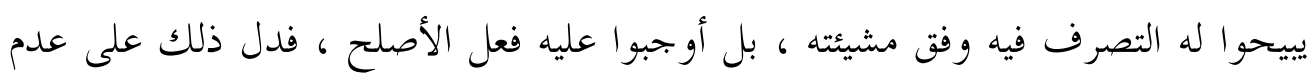

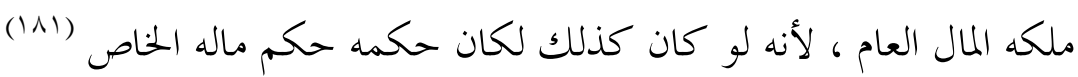

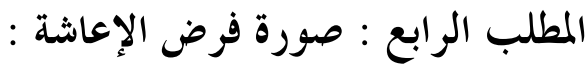

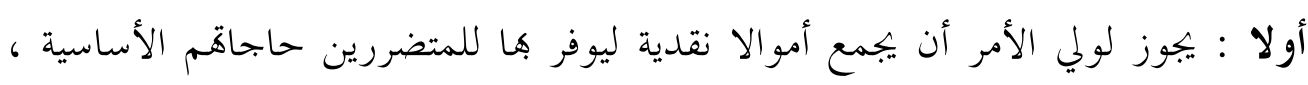

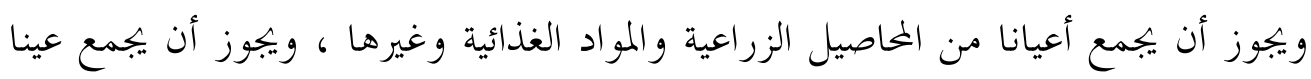
ونقدا بحسب ما يتوافر لدى الأفراد ـ ـوفي هذا الظرف الاستنائي ينبغي عليه تقديم الأهم

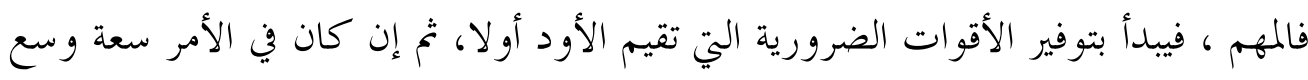

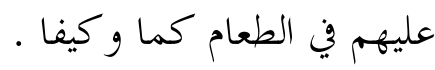

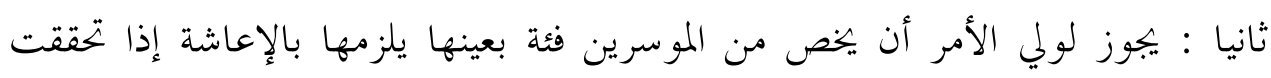

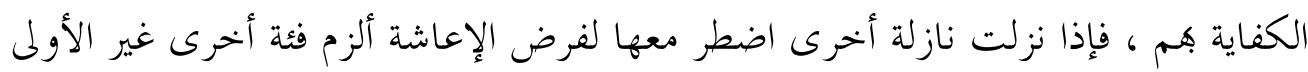

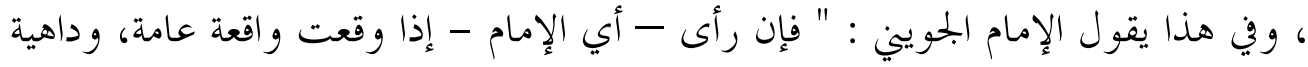

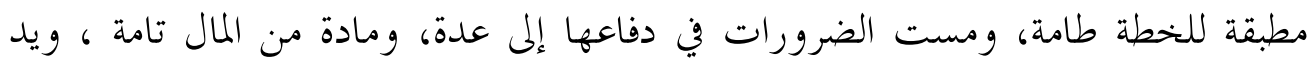

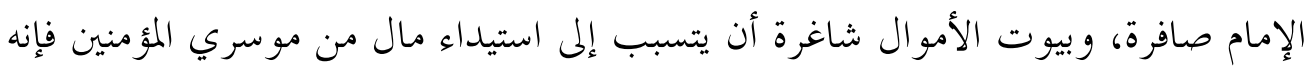

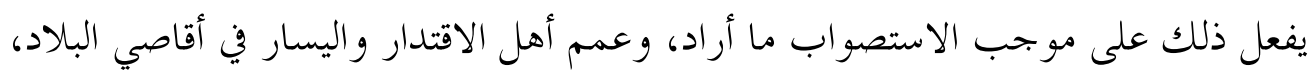

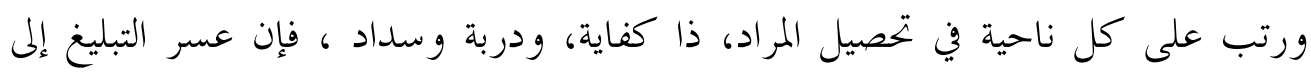

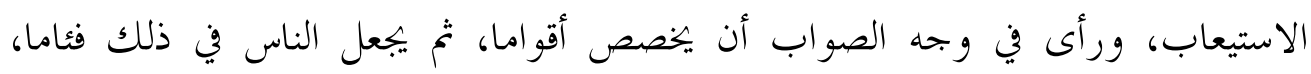

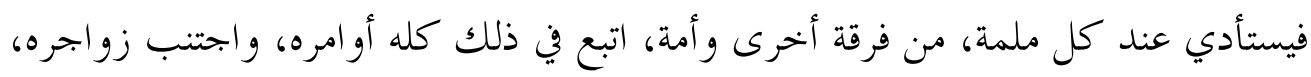

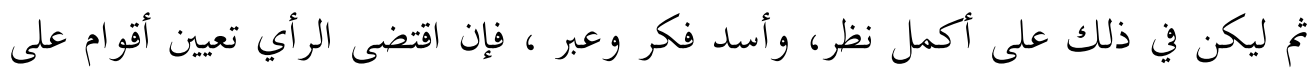

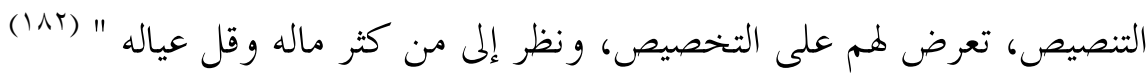

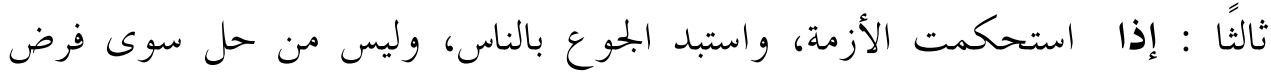

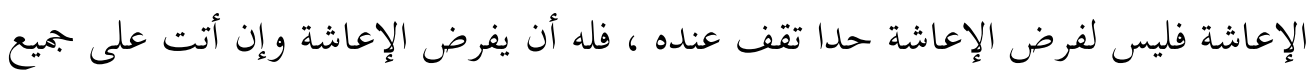




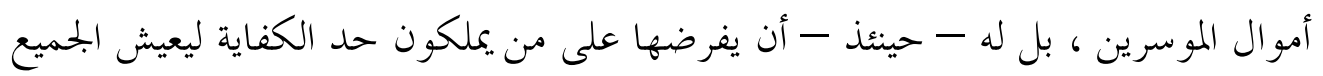

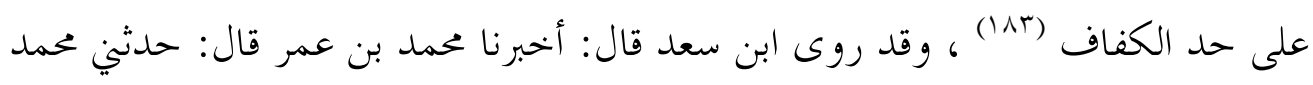

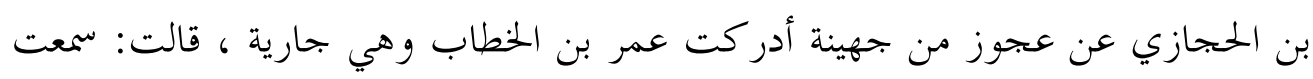

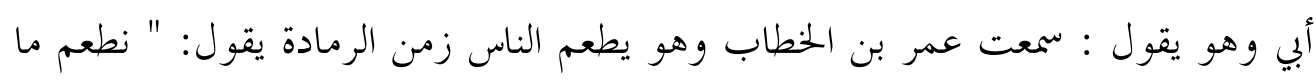

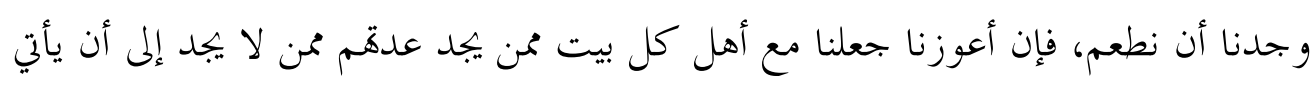

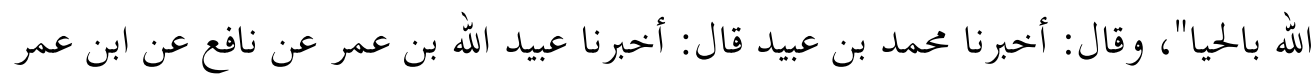

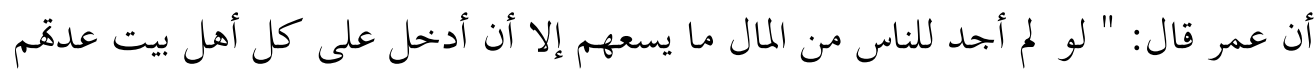

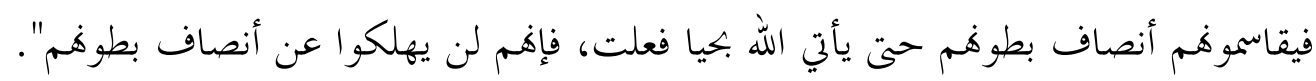

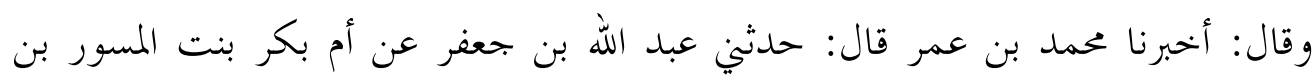

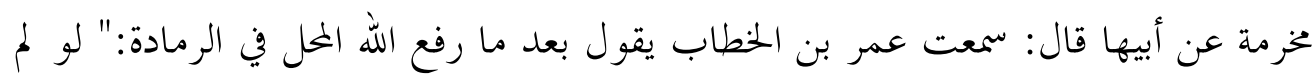

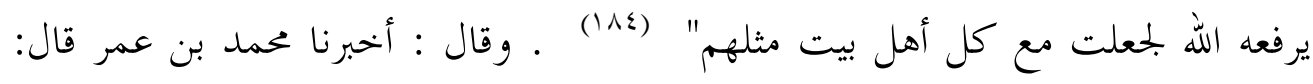

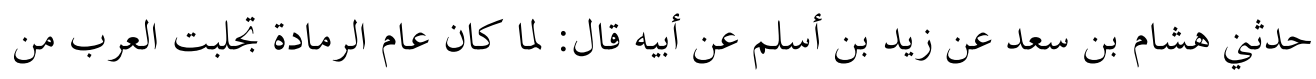

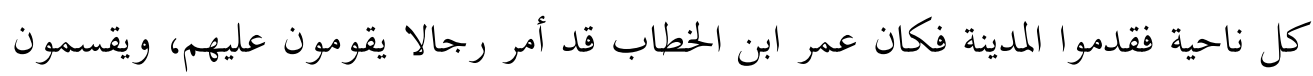

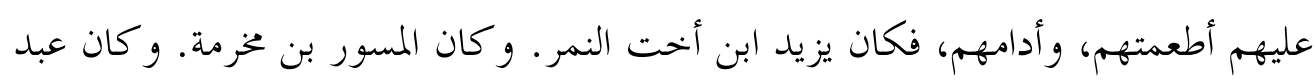

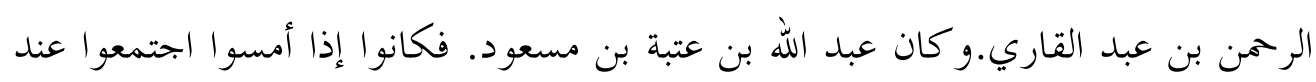

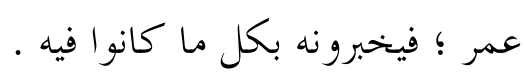

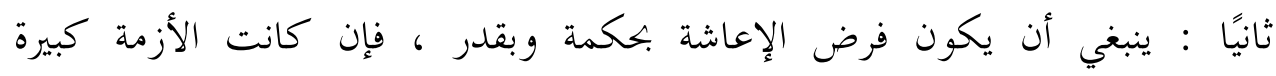

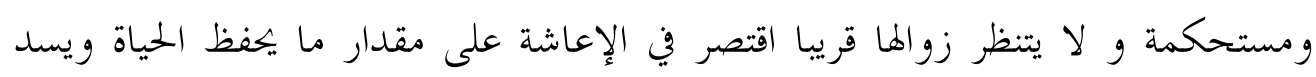

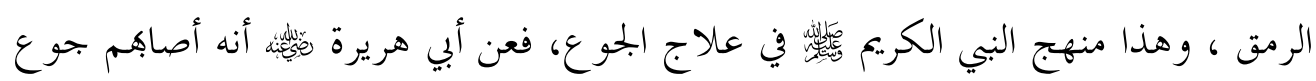

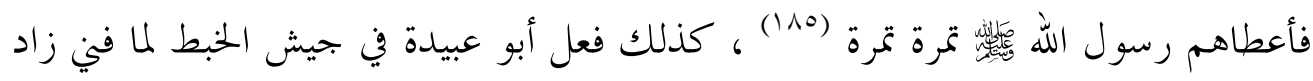

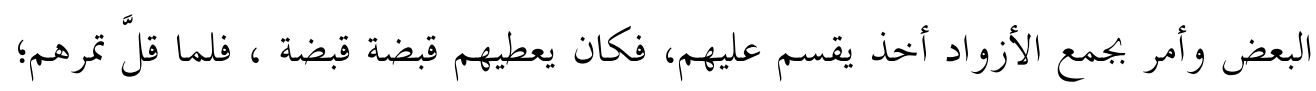

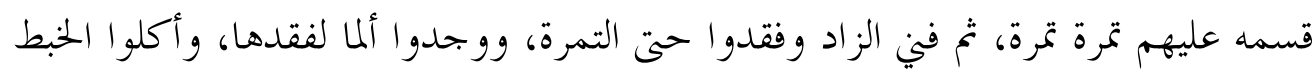

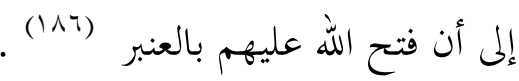


ثالثا : إن كان في الأمر متسع لأن يجمع الأموال ثم يوزعها على المنكوبين ليشتروا

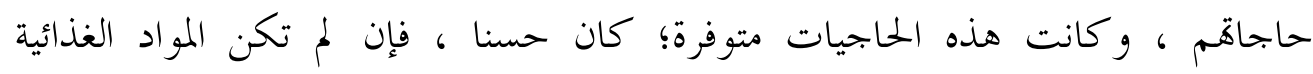

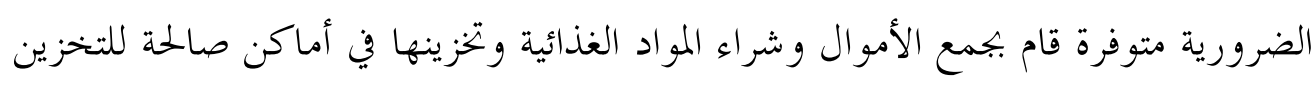

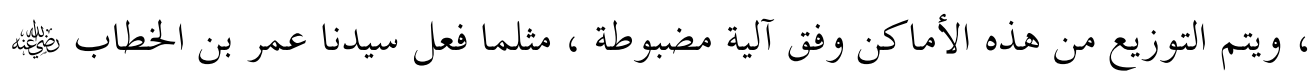

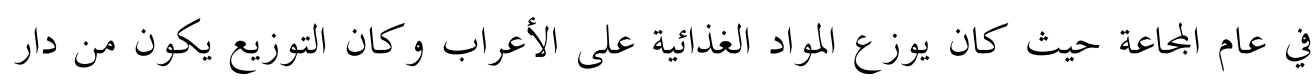

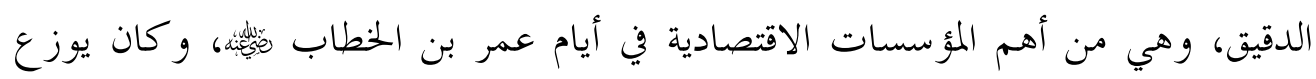

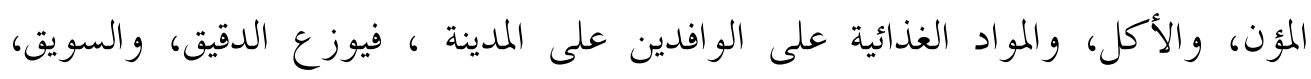

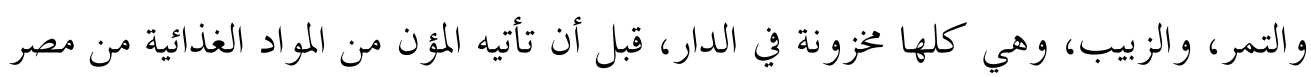

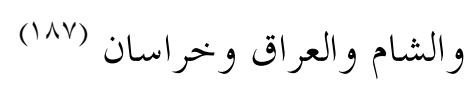

أو يقوم بتوزيع المواد الغذائية الضرورية عبر بطاقات تموينية أسبوعيا أو شهريا لكل فرد الفران

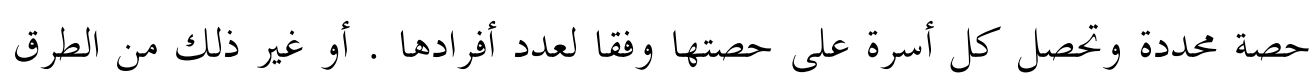

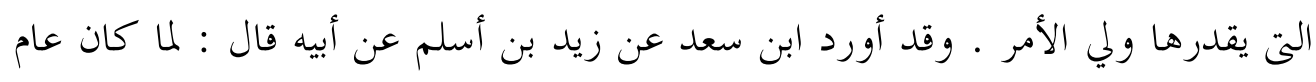

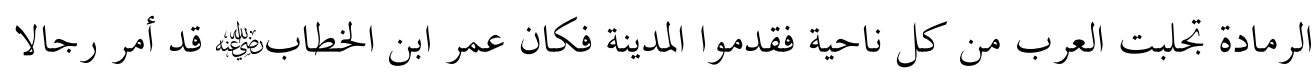

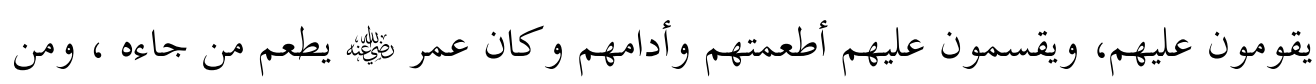

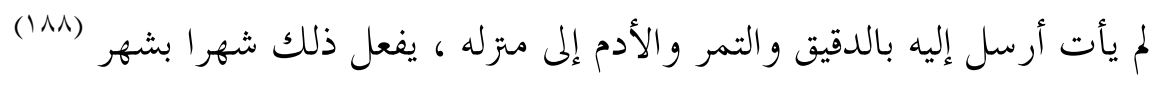

و بعد هذا العرض والمناقشة لمسألة مدى سلطة ولي الأمر في فرض إعاشة الناس بعضهم

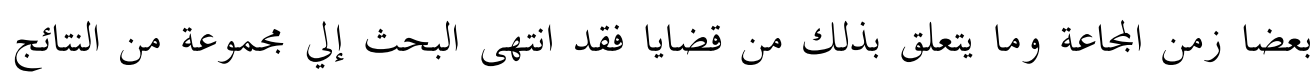

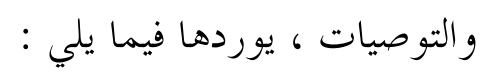

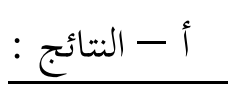
أولا : ولي الأمر هو الحاكم العام للدولة الإسلامية ، وقد التخذ هذا المنصب عدة مسميات عبر

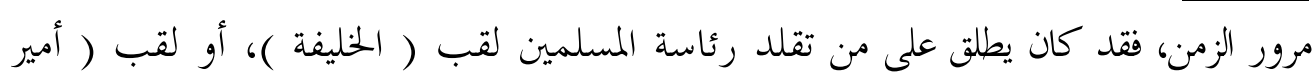

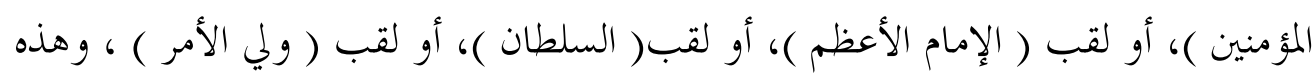


الألقاب جميعها تستعمل - في الأغلب - لتشير إلى معنى واحد ، وهو رئيس الدولة بالاصطلاح المعاصر ، و الذي يعني الرئيس الأعلى للسلطة التنفيذية . ثانيًا : المجاعة " زمن الجموع والقحط ، وهى عبارة عن فشل على الصعيد الإقليمي في

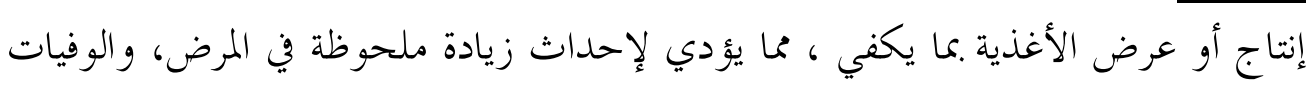

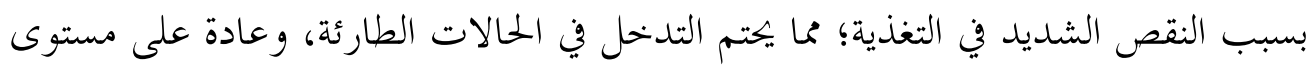
دولي، ولا تصنف البحاعة على إذا كارثة ، إنما هي أثر ونتيجة لتلك الكوارث، الطبيعية منها أو البشرية. ثالثا : للجوع تأثيرات بالغة الخطورة على المستوى الجسمي، والعقلي ، أبتنتها الدراسات والبحوث الحديثة، فإذا استبد الجوع بالإنسان واستمرت هذه الحال يصيب الإنسان نوع من المذيان التهيجي ؛ فيفقد الإدراك، ونئول به الحال إلي أعمال تربتف منها الطبيعة البشرية ، كما أها تدل علي وهن تلك الطبيعة ،

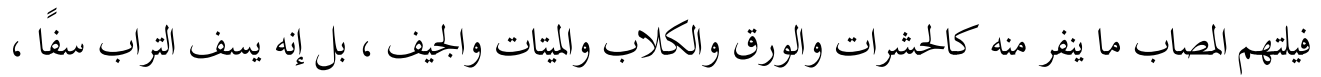
بل يأكل الإنسان أخاه الإنسان ، وكلها تصرفات وقعت بالفعل عبر تاريخ بلماعات الطويل ونقلها المؤرخون و اقعا معيشا عاشوه وعاينوا وقائعه بأنفسهم ، ويحدث في الوقت نفسه تغير عميم في نظام الجمسم

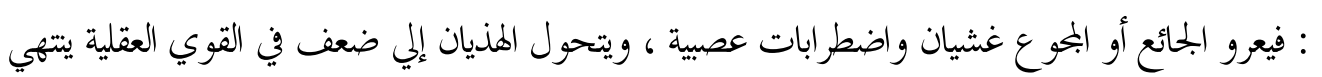
بالجنون ، أما الجمسم فيصبح من جراء الهزل أشبه شيء بقفص عظام ، وبيات عرضة لجميع الأمراض ، إلي أن تتنهي هذه الحالة بتالشي جميع القوي ، أي بالموت .

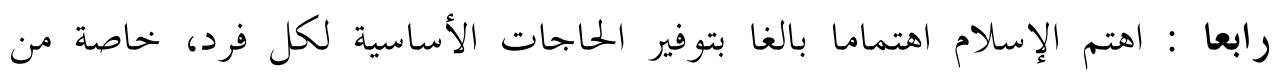

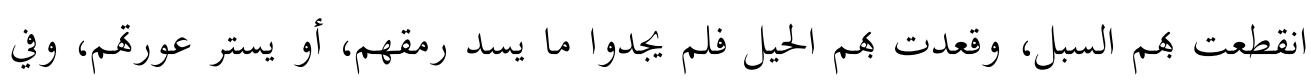
وقت الكوارث ألزمت الشريعة الإسلامية الدولة بإغاثة كافة المختاجين، والمنكوبين، ولهذا قرر فقهاء الإسلام بأن من ليس له قريب غني وهو فقير عاجز فإن نفتته على خزانة الدولة، إنها

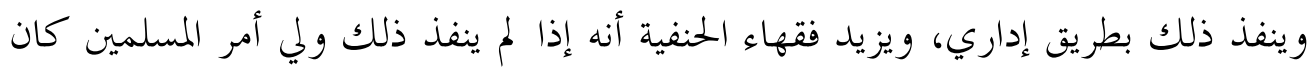

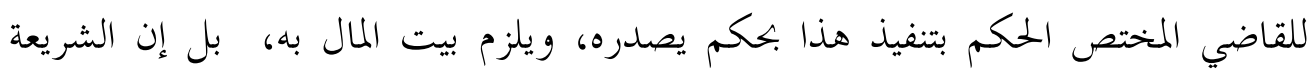

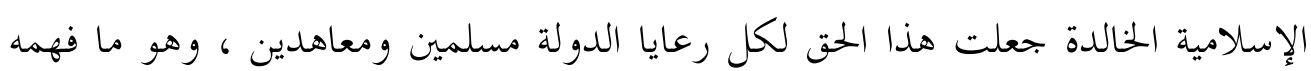
الصحابة، ومن بعدهم، وطبقوه عمليا ، والأمثلة على ذلك كثيرة . 
خامسًا : لا يحل أحذ مال أحد إلا لضرورة تعرض؛ فيؤخذ ذلك المال جهرا لا سرا،

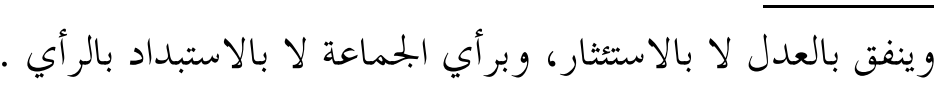

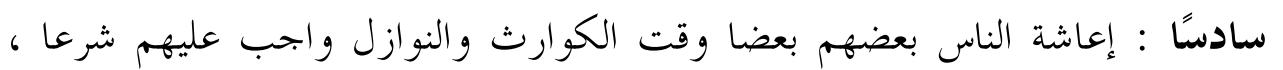

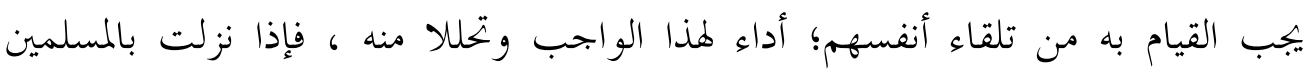

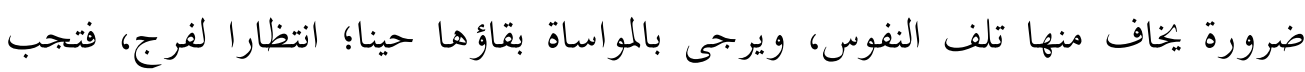

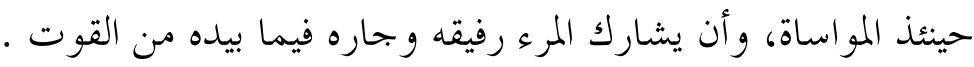

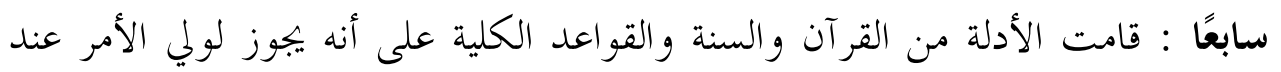

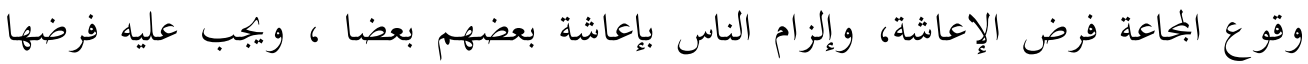

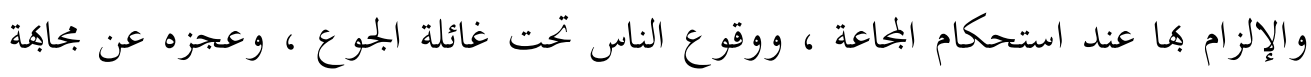

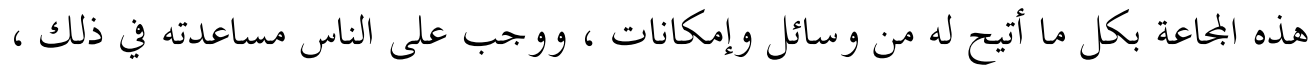

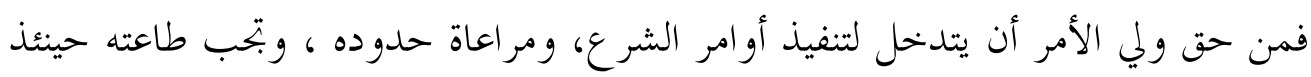

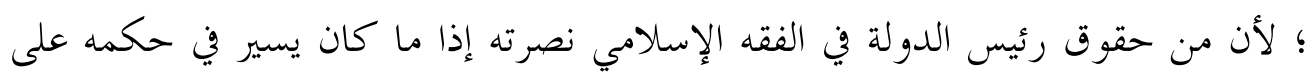

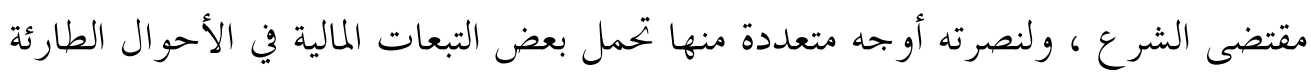

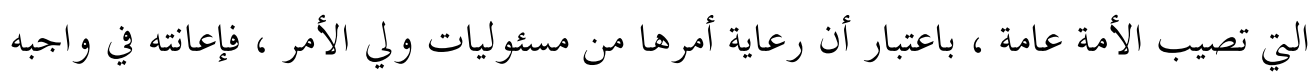

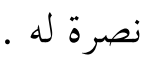

ثامنًا : ثُمة قيود ترد على سلطة ولي الأمر في فرض الإعاشة ، تتمثل في :

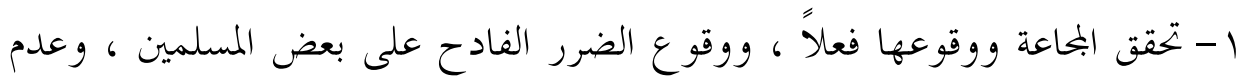

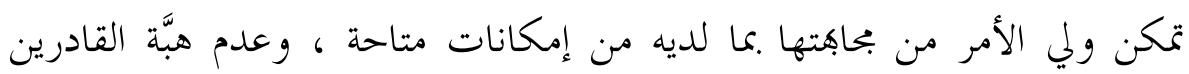

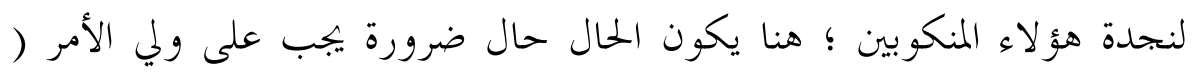

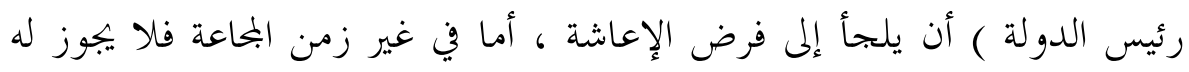
ذلك.

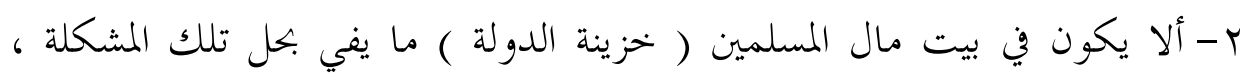

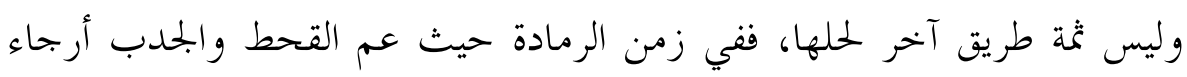

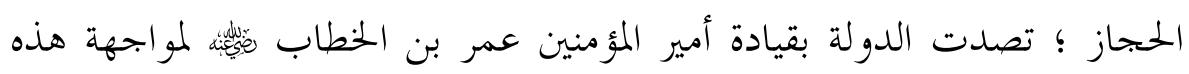




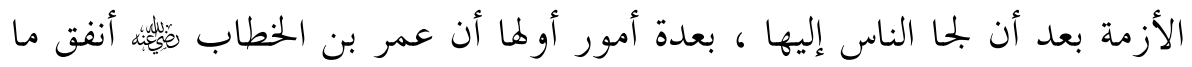
بقي في بيت المال من الطعام والمال حتى نفد ، فيجب على ولي الأمر أنه متى وقعت رعيته في ضائقة أو حصلوا في شدة وفاقة أن يعينهم بالطعام ، ويساعدهم من خز ائنه بالمال . من وعينه r- هذا الإجراء مخول لولي الأمر فقط ( رئيس الدولة) أو من يمثل أعلى السلطة التنفيذية ، فليس لأحد غيره فرض الإعاشة إلا بقرار منه، أو إذن ، فقد فئ فعل البني

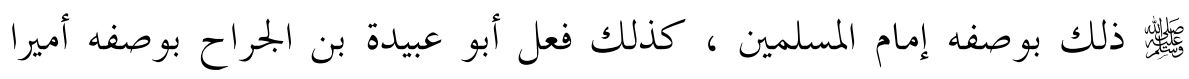

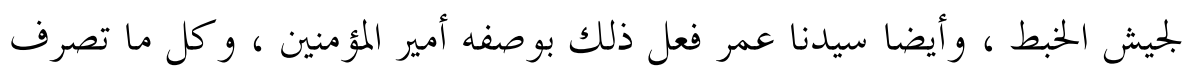

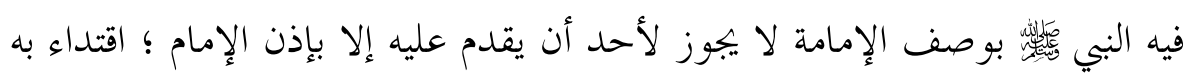
. 整战 ع - أن يسبق فرض الإعاشة دعوة ولي الأمر الجميع للتبرع كل بحسب قدرته المالية ،

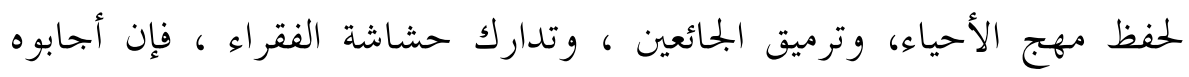

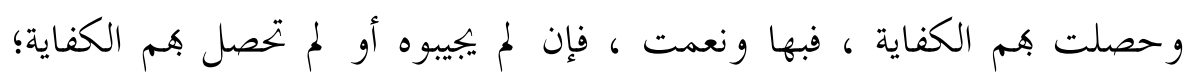

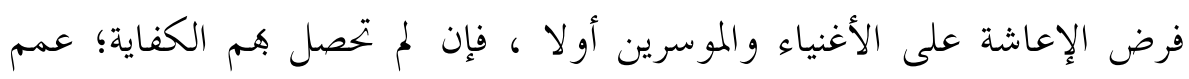

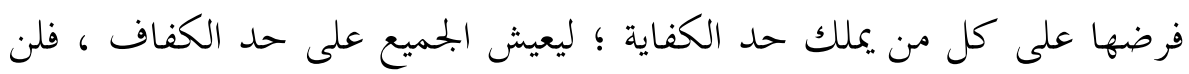

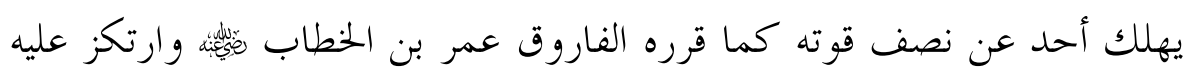
في خطته الاقتصادية في عام الرمادة . ه- أن يراعي في توجيه الإعاشة الأكثر ضررا، ثم الذي يليه ، وأن يكون العطاء على العي قدر الحاجة، وما يسد الخلة ، وتقدير النفقات بالحاجات مع تفاوها عدل وتسوية لإسل ج- أن يزول هذا الحتم والإلزام بزوال البحاعة ، إذ إن حق فرض الإعاشة حق طارئ

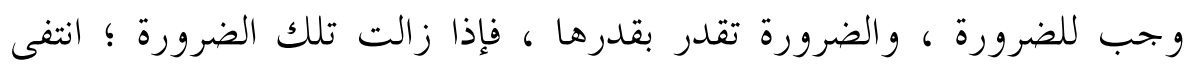
ذلك الحق ، فهذا الفرض والإلزام إنما هو اجراء وقتي لا يلبث أن يزول بزورال 
V- العدل في فرض الإعاشة والإلزام ها ، و لا يقصد بالعدل "المساواة" ؛ لأن المساواة

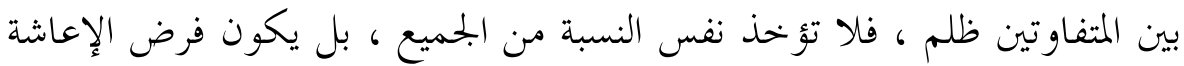
بطريقة النسبة كما هو الحال في الزكاة ، كلما زاد المال؛ زاد الحظظ في تحمل الإعاشة ، فليس من العدل أن يتحمل الفقير القسط نفسه الذي يتحمله الغني . ^- مال البحث إلي أن عدالة الإمام ليست قيدا لفرضه الإعاشة، إنما هي مستحبة ، ذلك لأن الإعاشة واجبة شرعا على الناس وقت الكوارث ابتداء، فلو قهاونو إيها

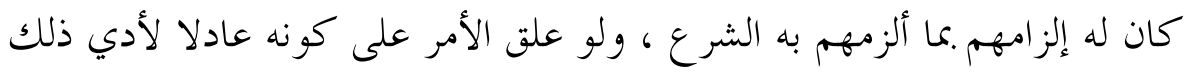
- ر.بما- إلى هلاك الناس بالجموع. تاسعًا : اختلف العلماء فيما إذا خلا بيت المال واحتاج الإمام إلي المال في حرب أو أو

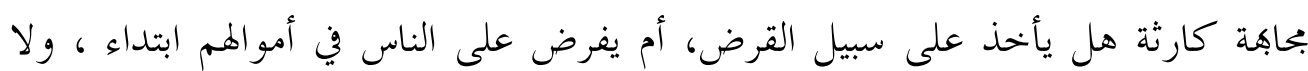

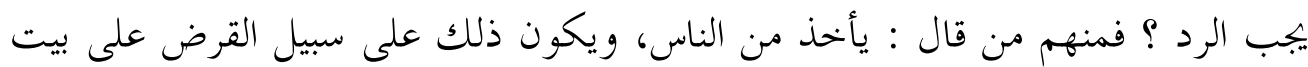

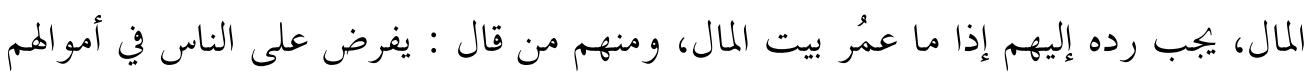
ابتداء ، ولا يجب الرد إلا إذا كان لبيت المال دخل يرتجى ، ومنهم من قال : يفرض ابتداء

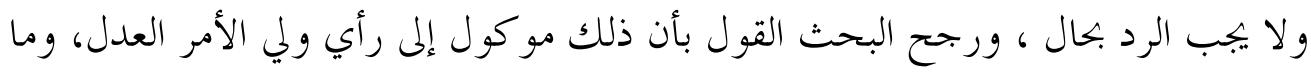

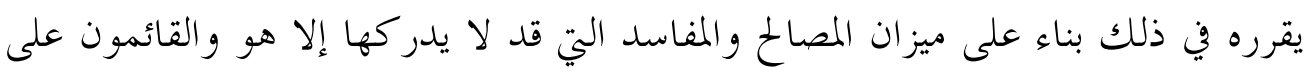

$$
\text { أمور الدولة والاقتصاد من العدول ذوي الخبرة والدراية . }
$$

عاشرًا : إذا وقعت المحاعة وتقاعس ولي الأمر عن بنحة المنكو بين وترميق الجائعين ، أو لم يبلغ جموع المسلمين نظر الإمام ؛ فلا يبجوز الانتظار بحال ، ويجب على ذوي اليسار والاقتدار البدار إلى رفع الضرار عن هؤلاء الجائعين والمنكوبين ، و إن ضاع فقير بين ظهراني

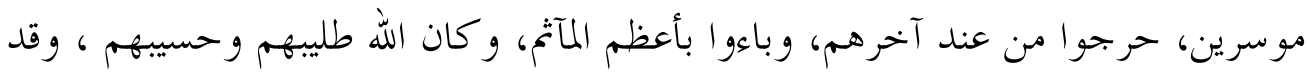

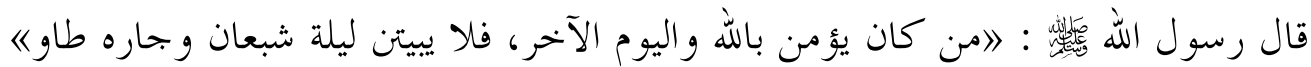

حادي عشر : لولي الأمر فرض الإعاشة بما يراه كفيلا بحفظ المهج، وترميق الجوعى ، وله أن يقيّم الوضع وفق خطة مدروسة تقوم على تحديد مدة بقاء المحاعة، ومقدار ما يمكن 
توفيره من الأموال والأعيان ، وحساب النسبة بينهما لتحديد مقدار ما يمكن توزيعه ، فإن

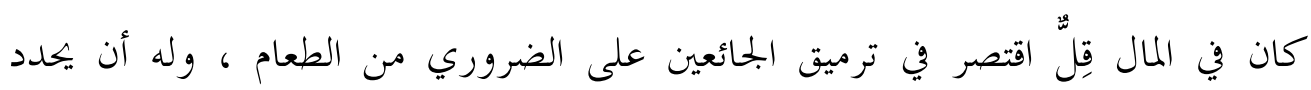

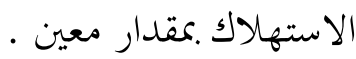

ثاني عشر : فرض الإعاشة إجراء استنائي سريع لإنقاذ الجموعى والمنكو بين ، ومن ثم فلا

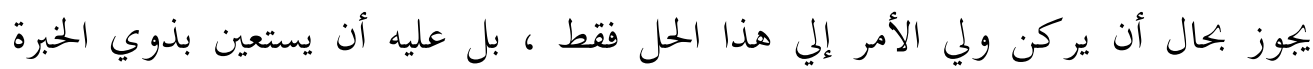
والدراية لوضع خطة عاجلة وحاسمة لإنقاذ البلاد والعباد .

$$
\text { و يوصي البحث بما يلي : التوصيات : }
$$

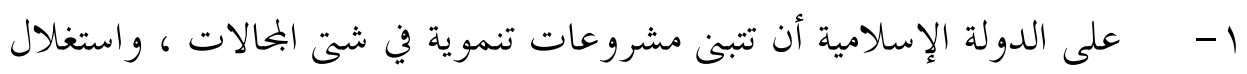

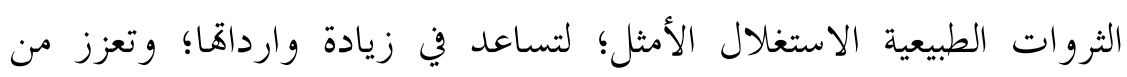

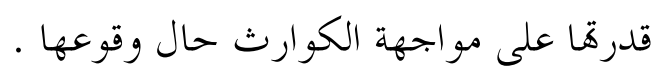

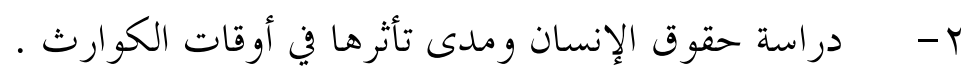

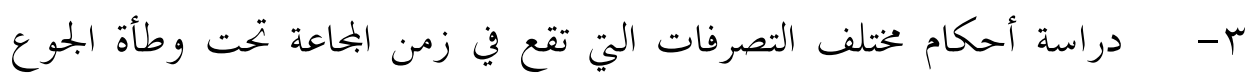

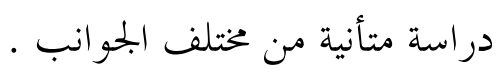
المراجع والمصادر :

1-الإجهاج في شرح المنهاج ((منهاج الوصول إلي علم الأصول للقاضي البيضاوي

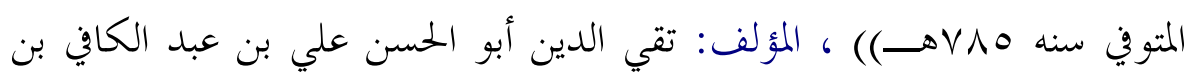

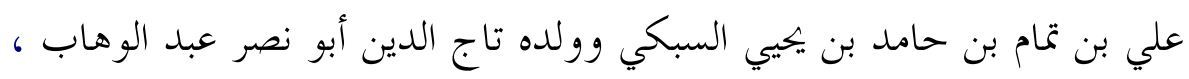

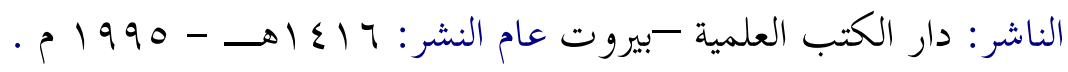

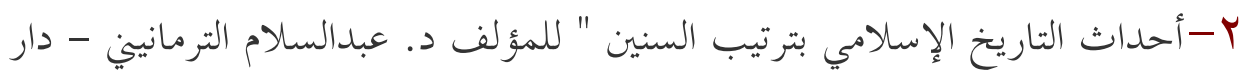

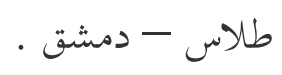


ب-أحكام القرآن ، أحمد بن علي أبو بكر الرازي الجصاص الحنفي (المتوف:

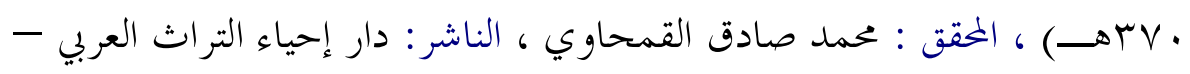

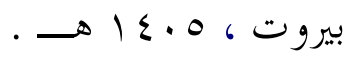

ع-أحكام القرآن ، محمد بن عبد الله أبو بكر بن العربي المعافري الاشبيلي المالكي

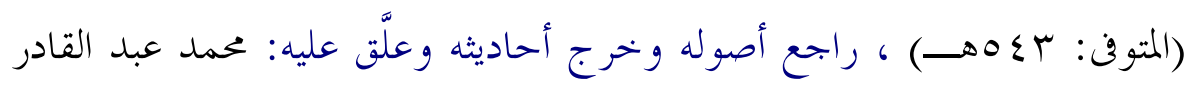

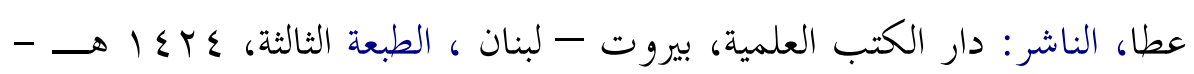
$\cdot r \cdot r$

0-اختصاصات السلطة التنفيذية في الدولة الإسلامية والنظم الدستورية المعاصرة ، دم/

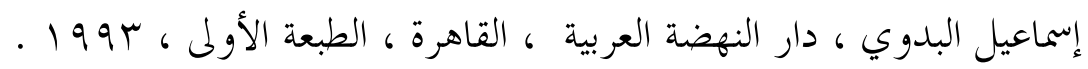

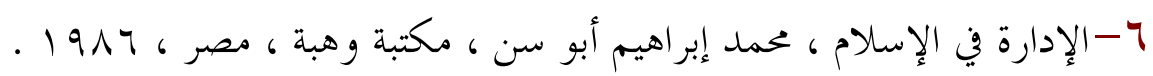
- V الأشباه و النظائر ، عبد الرحمن بن أبي بكر، جلال الدين السيوطي (المتوفن: 11 91

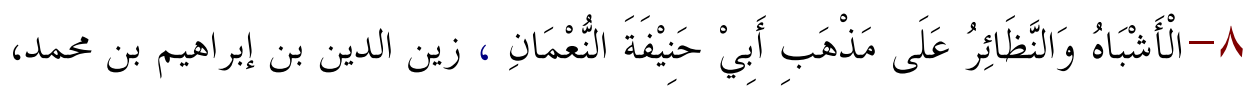

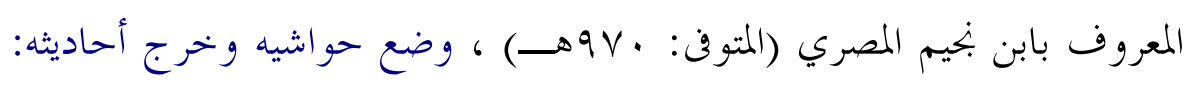

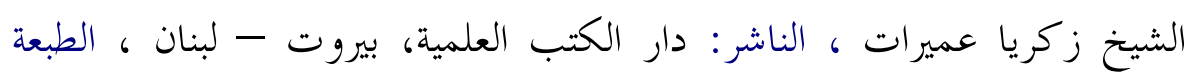

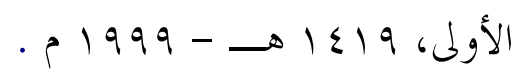
9 - أصول الاقتصاد الإسلامي ، د/ رفيق المصري ، دار القلم ، دمشق ، الطبعة الأولى . r. I. 6

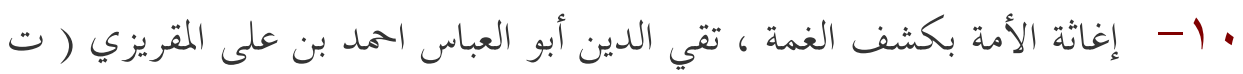

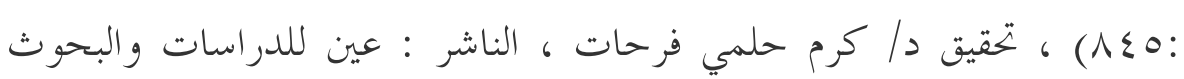

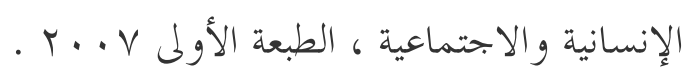

1 - الإفادة والاعتبار في الأمور المشاهدة والحوادث المعاينة في أرض مصر ، عبد اللطيف بن يوسف بن محمد بن علي البغدادي، موفق الدين، ويعرف بابن اللباد، 
وبابن نقطة (ت : 9 Y7ه) ، الهيئة المصرية العامة للكتاب ، مصر ، الطبعة الثانية ، .1991

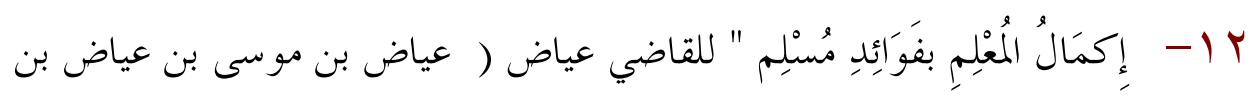

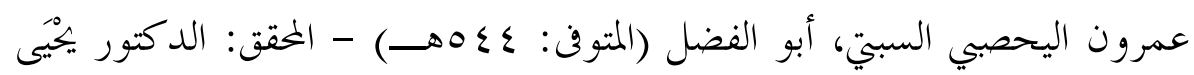

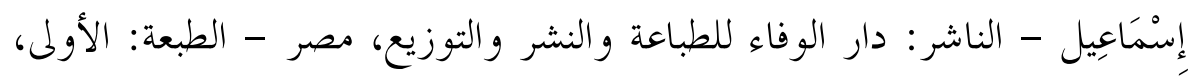

$$
\text { . } 1991-\rightarrow 1 \leqslant 19
$$

با - - الألقاب الإسلامية في التاريخ والوثائق ، د/ حسن الباشا ، الدار الفنية للنشر

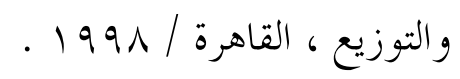

ع ا- - الأموال ، ابن زبخويه أبو أحمد حميد بن مخلد بن قتيبة بن عبد الله الخراساني

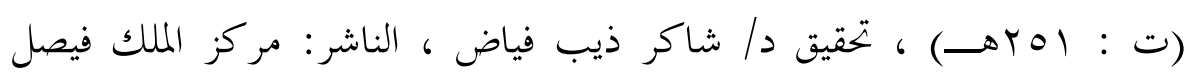

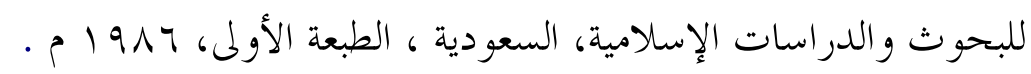
1 - - الأموال ، أبو عُبيد القاسم بن سلاّم بن عبد الله الهروي البغدادي (ت :

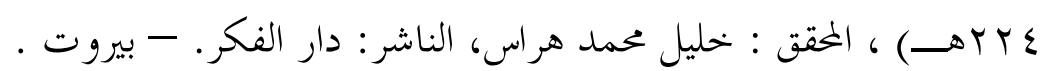
7 ا 1 - البحر الرائق شرح كتز الدقائق " لابن بنيم المصري ( زين العابدين بن إبراهيم بن بنيم المصري ت • لوهـــ ) - دار الكتاب الإسلامي- القاهرة .

IV

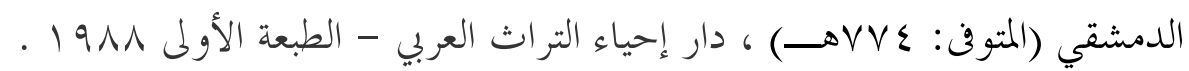
1 ا - بدائع الصنائع في ترتيب الشرائع " للكاساني ( علاء الدين أبو بكر بن مسعود

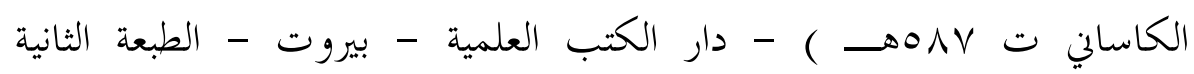
. - $1 \leqslant .7$

9 1 - البناية شرح الهداية ، أبو محمد محمود بن أحمد بن موسى بن أحمد بن حسين الغيتابى الحنفى بدر الدين العينى (المتوفى: 100هــ) ، الناشر: دار الكتب العلمية -

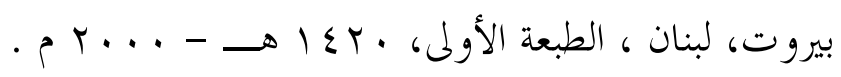




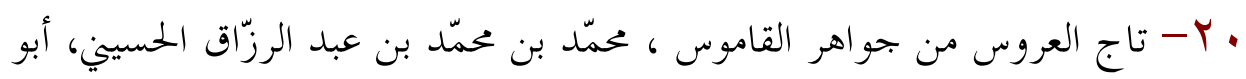

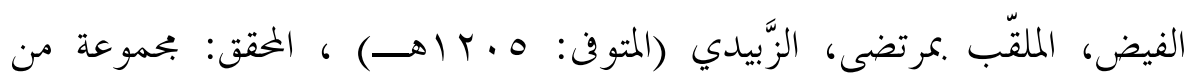

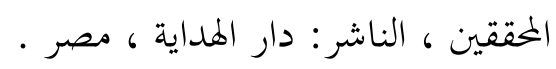

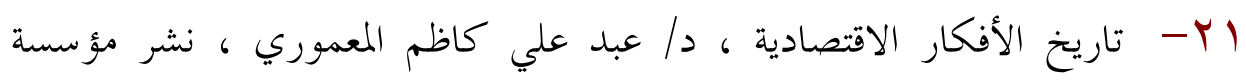

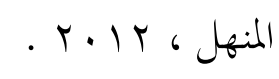

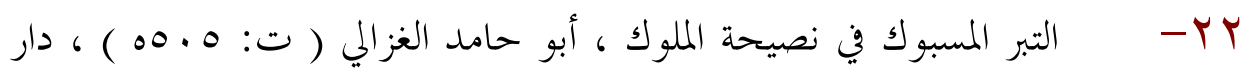

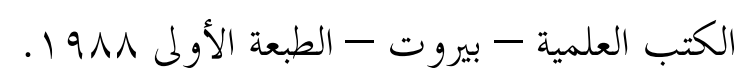

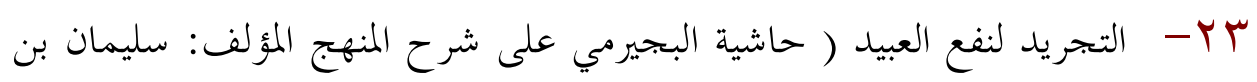

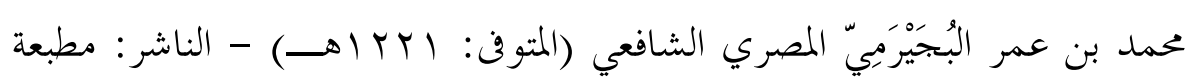

$$
\text { الحبلي ، } 190
$$

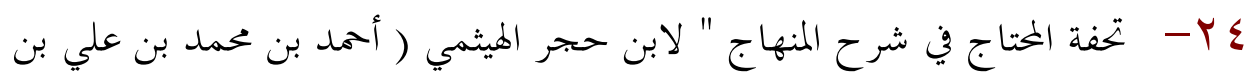

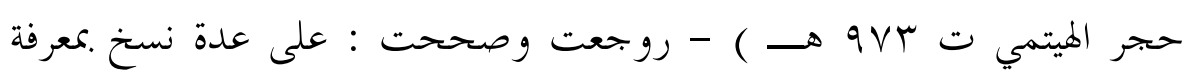

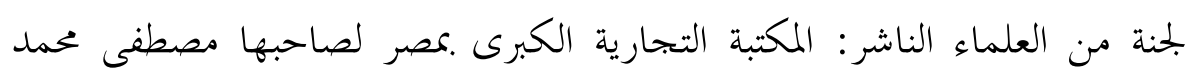

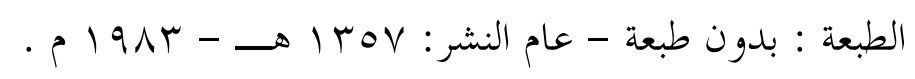

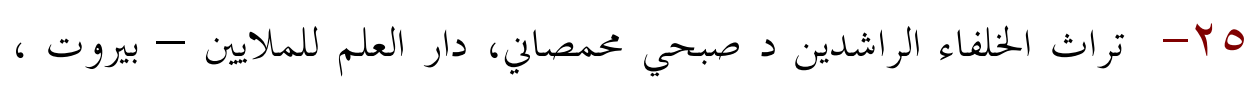
$191 \varepsilon$

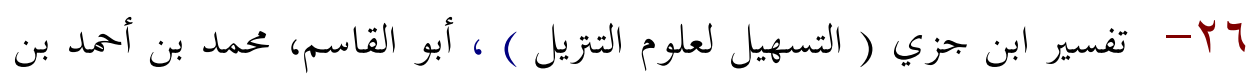

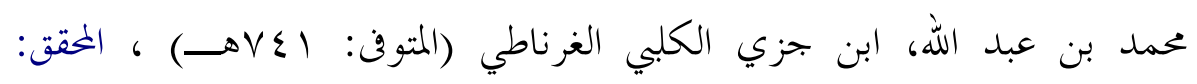

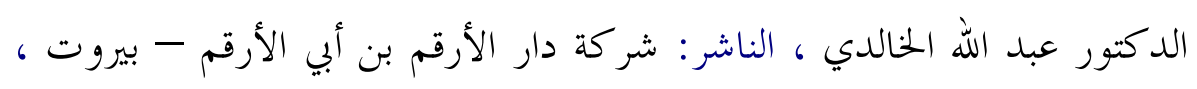

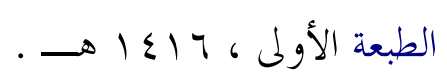

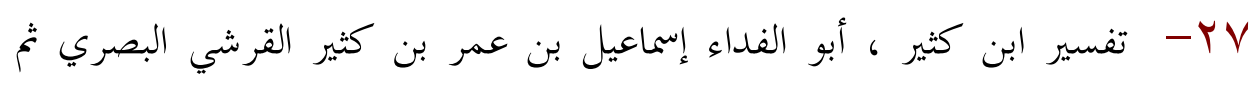

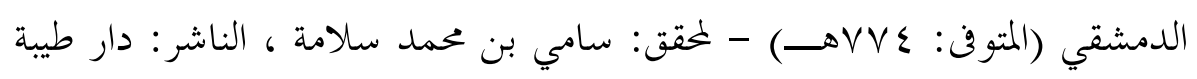

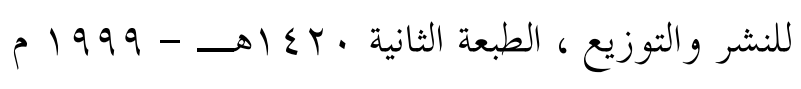


A ب - تفسير البحر الخيط : أبو حيان محمد بن يوسف بن علي بن يوسف بن حيان

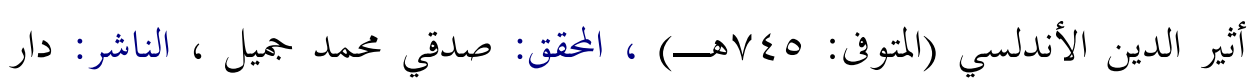

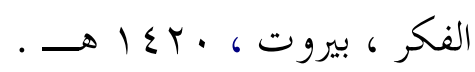

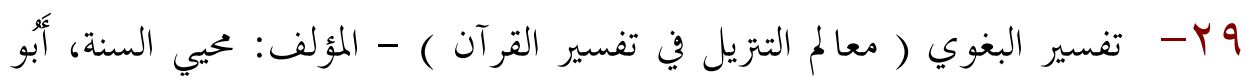

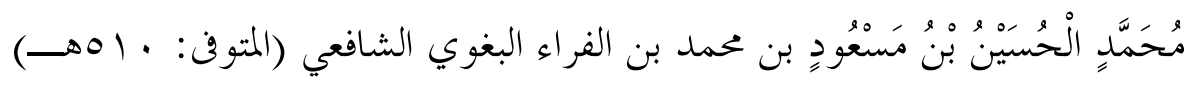
- الحقق: عبد الرزاق المهدي - الناشر: دار إحياء التراث العربي - بيروت -

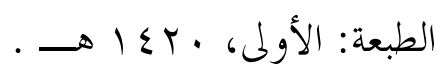

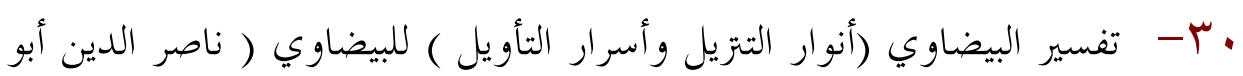

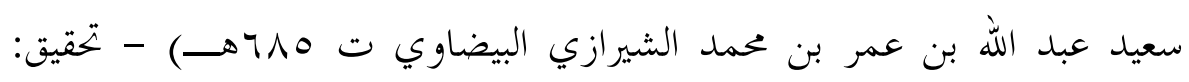

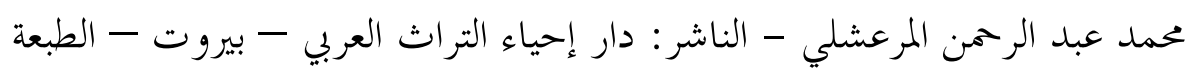

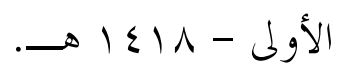

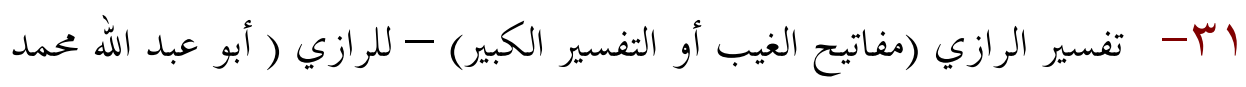

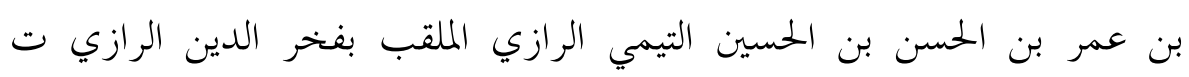

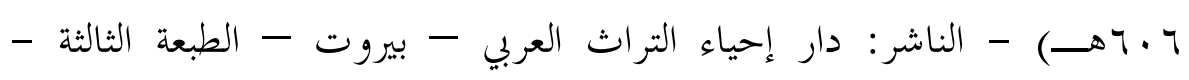
$\rightarrow 1 \leqslant r$.

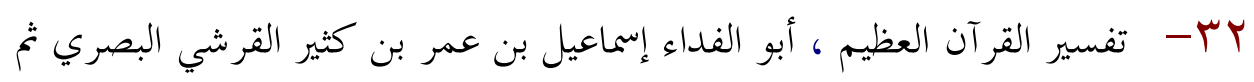

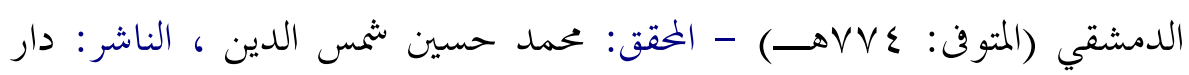

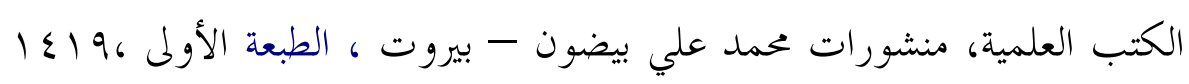

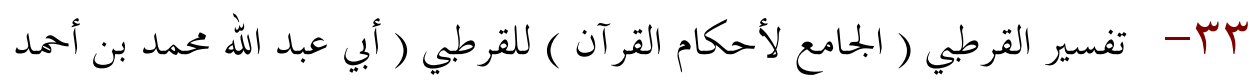

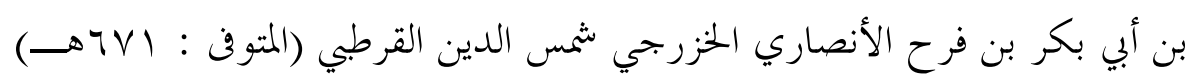

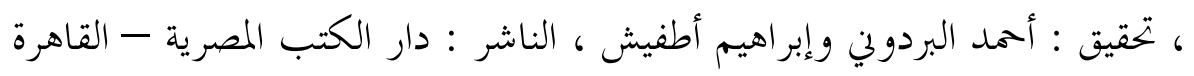

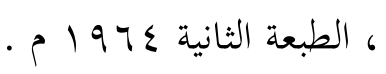


§ ץ- ت تفسير الماوردي ( النكت والعيون ) ، للماوردي ( أبي الحسن علي بن محمد

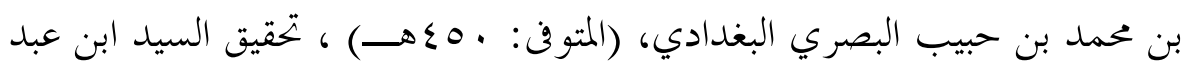

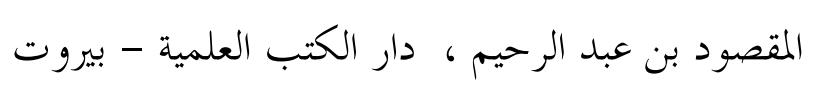

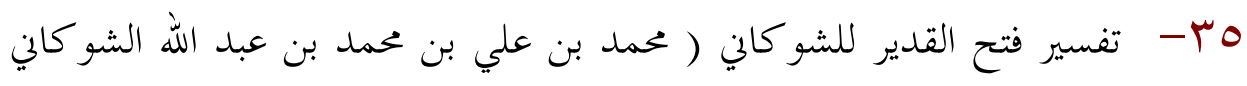

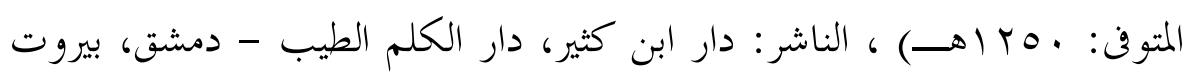

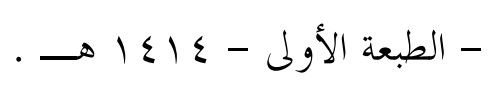

بس- التكافل الاجتماعي في الإسلام ، الشيخ محمد أبو زهرة ، طبعة دار الفكر الفر

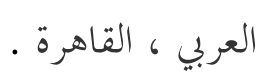

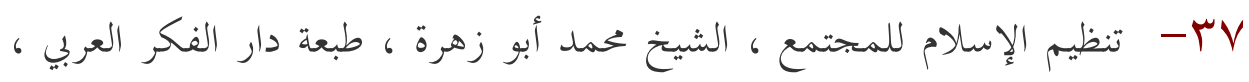

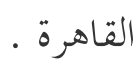

^ץ- - تنوير المقباس من تفسير ابن عباس ( تشרهــ) جمعه بحد الدين أبو طاهر

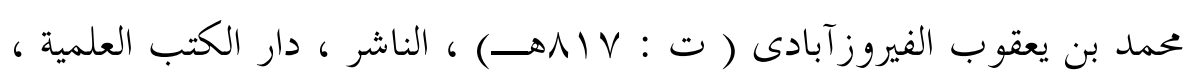

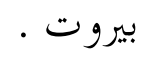

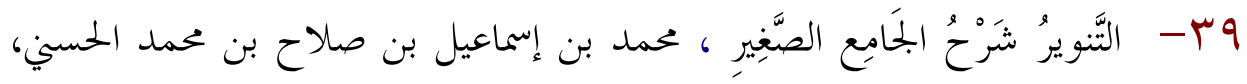

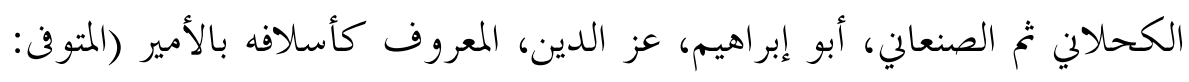

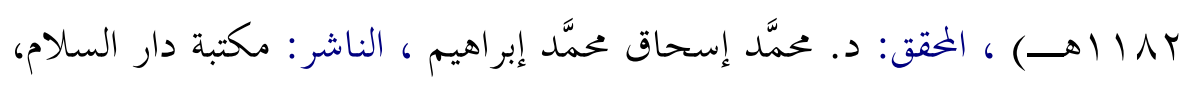

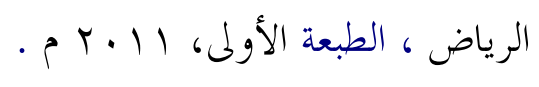

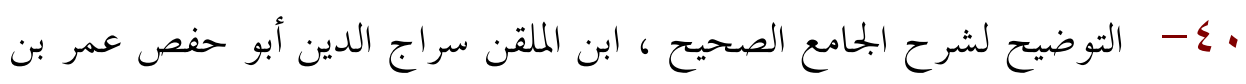

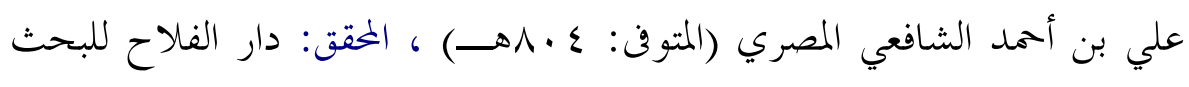

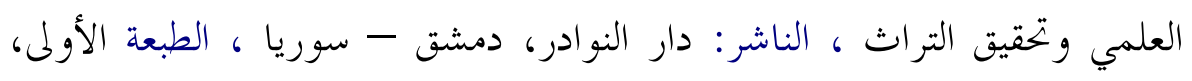

$$
\text { . }
$$




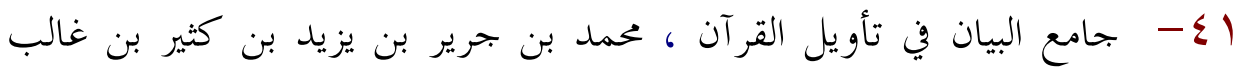

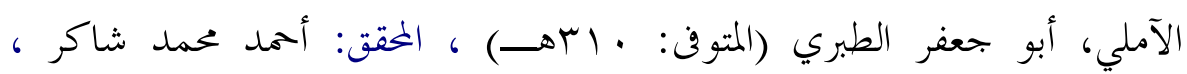

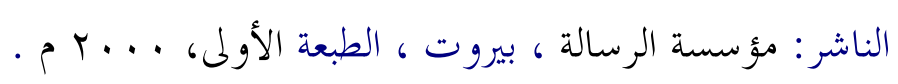
Y

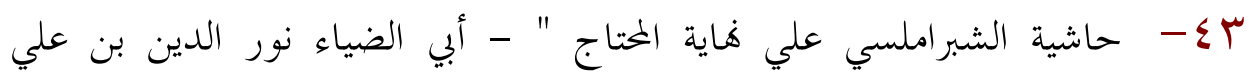
الشبراملسي الأقهري (1VV (1هـ) - دار الفكر، بيروت - الطبعة الأخيرة -

$$
\text { · }
$$

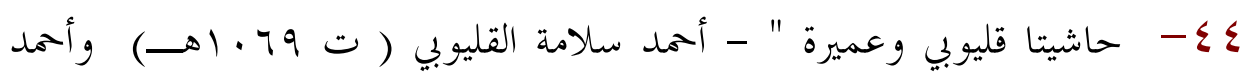

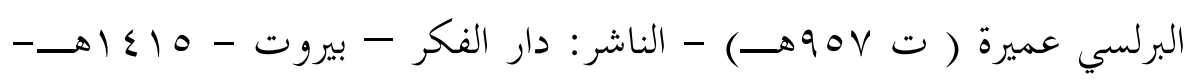
. 1990

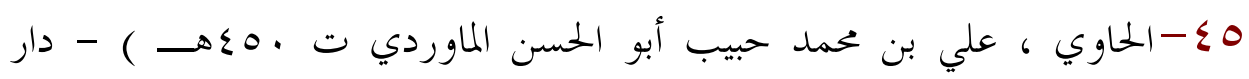

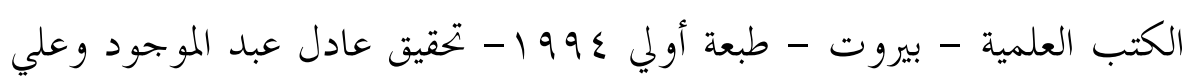

\section{معوض .}

7؟ - الحدود الأنيقة والتعريفات الدقيقة ، زكريا بن محمد بن أحمد بن زكريا

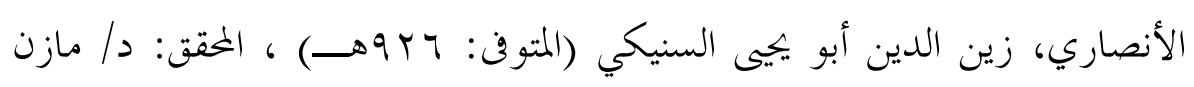

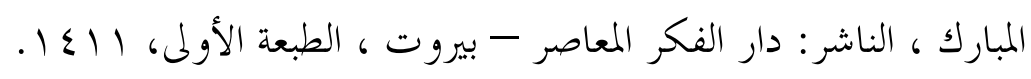

VV

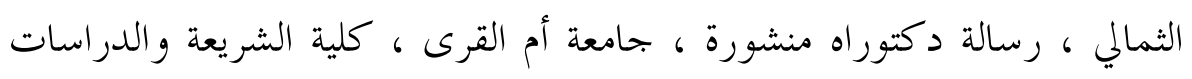

$$
\text { الإسلامية ، } 1910 .
$$

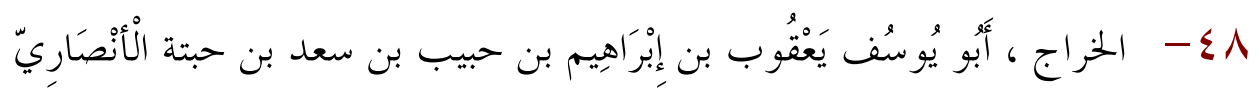

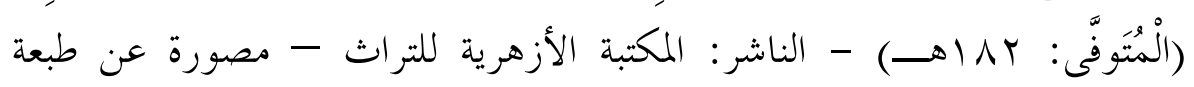

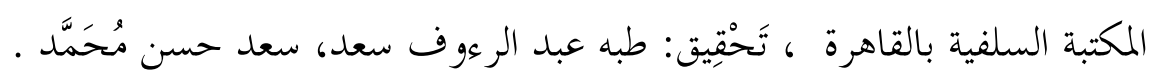


9 - - الخلافة ، محمد رشيد رضا ، الزهراء للإعلام العربي - القاهرة ، ـ99 199

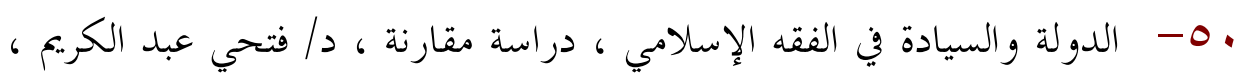

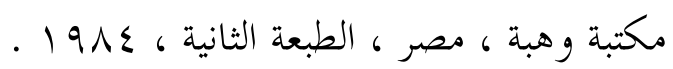

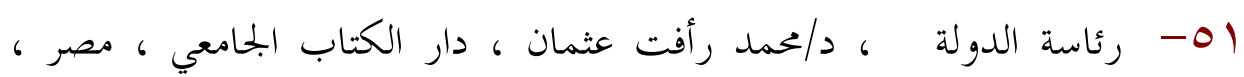
.1980

ror- الز كاة والضريبة دراسة مقارنة ، غازي عناية ، دار إحياء العلوم ، بيروت ، 1990

به- الزهد ، أبو عبد الله أحمد بن محمد بن حنبل بن هلال بن أسد الشيباني

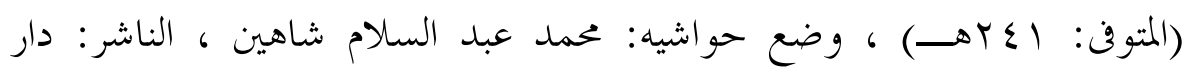

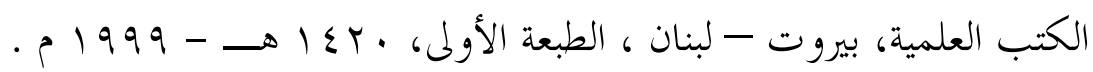
ع - سلسلة الأحاديث الضعيفة والموضوعة " للألباني ( محمد ناصر الدين الألباني )

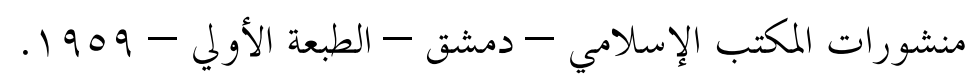

00-سنن ابن ماجة " لابن ماجة ( أبو عبد الله محمد بن يزيد ا بن ماجة القزويني

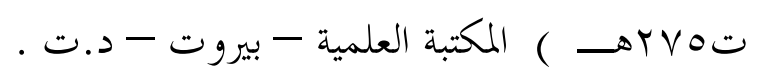

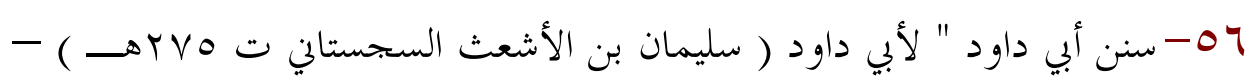
دار الكتب العلمية - بيروت - د. ت - تعليق محمد محيي الدين عبد الحميد . OV سنن الترمذي " للترمذي ( محمد بن عيسي بن سورة الترمذي ت IV9

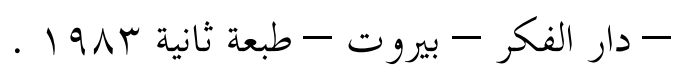

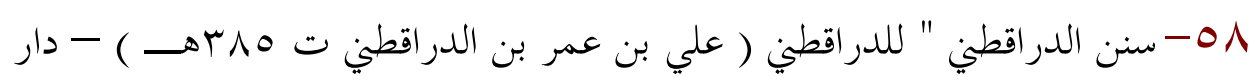

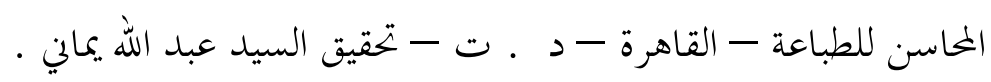

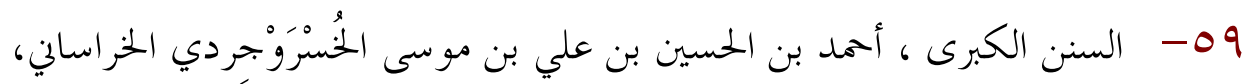

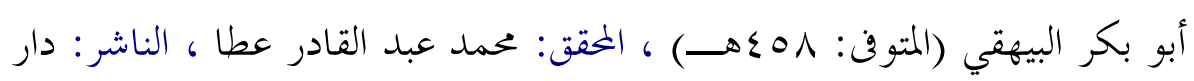

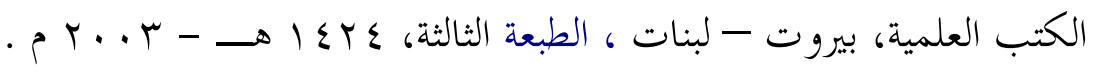


• 7- سنن النسائي " أو " الختبي" للنسائي ( أحمد بن شعيب بن دينار النسائي

$$
\text { توV9 تهـ ) دار الكتب العلمية - بيروت - د.ت . }
$$

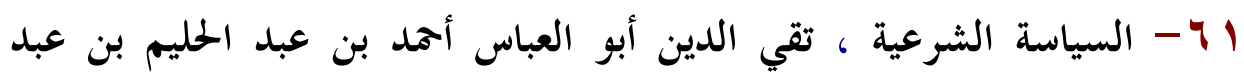

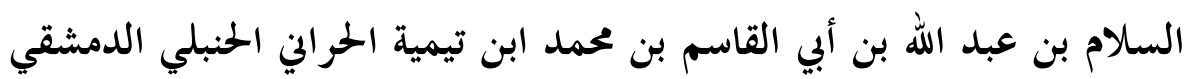

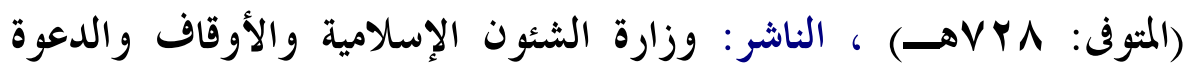

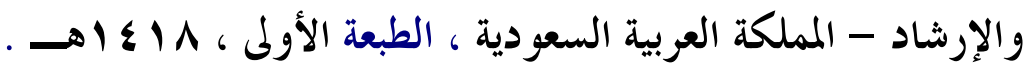

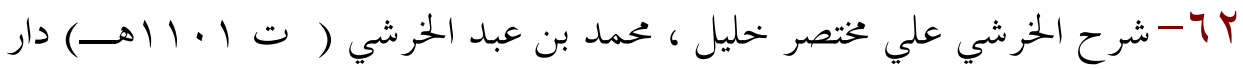

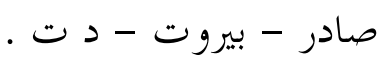

بآ-شرح الزرقاني علي غختصر خليل " للزرقاني ( عبد الباقي بن يو سف الزرقاني ت

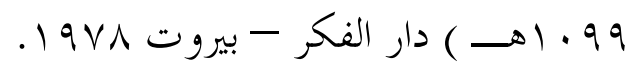

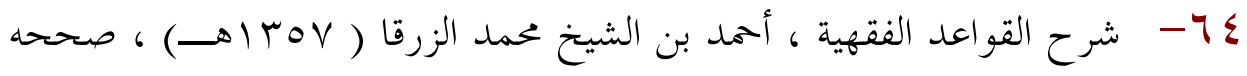

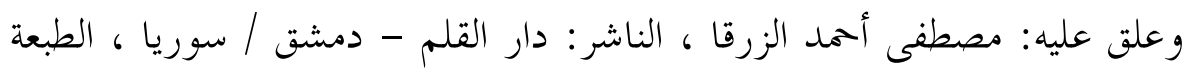

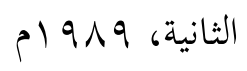

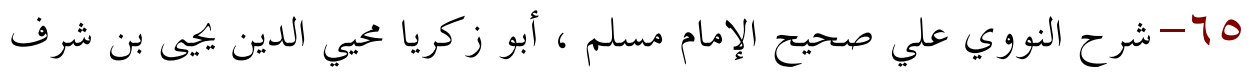

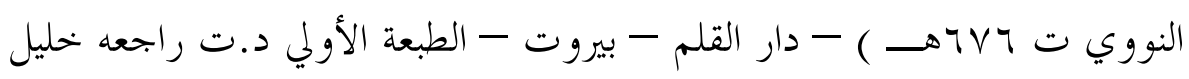

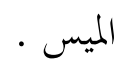

47- شرح سنن أبي داود ، أبو العباس أحمد بن حسين بن علي بن رسلان المقدسي

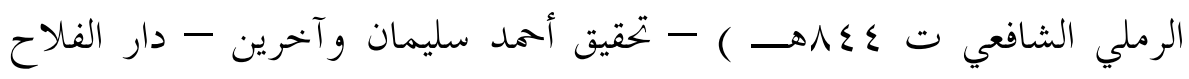

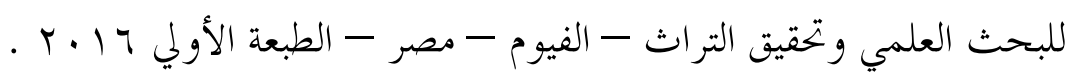
ب -TV

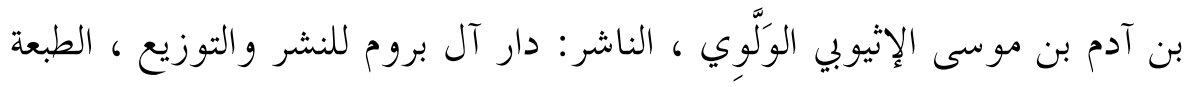

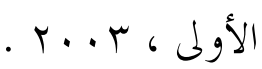


11

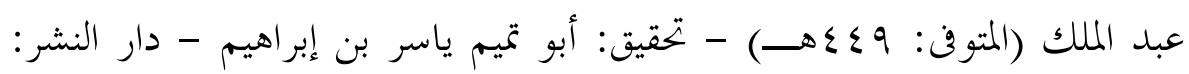

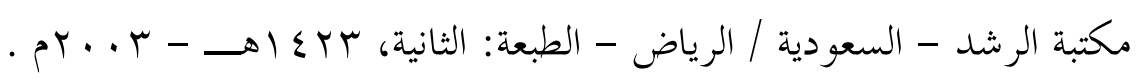

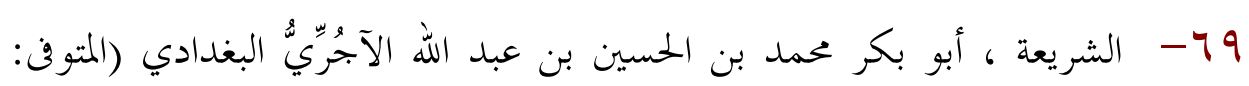

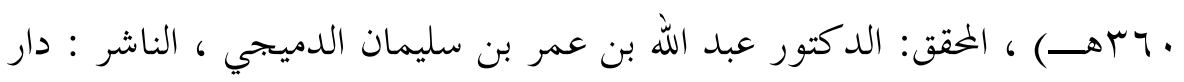

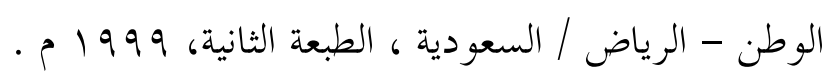

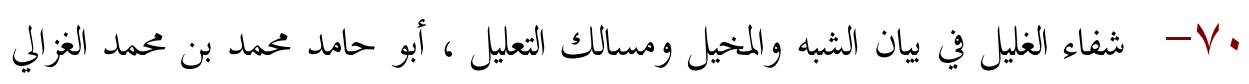

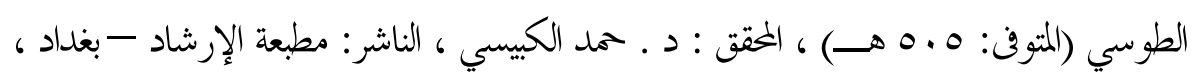

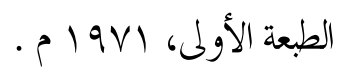

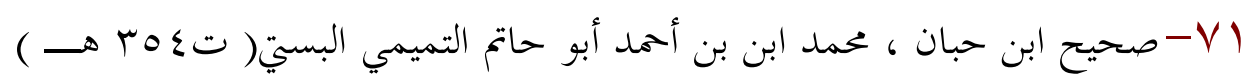

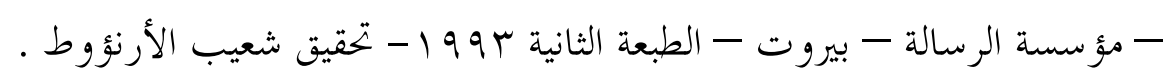
ك -VY

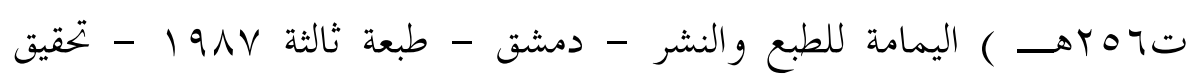

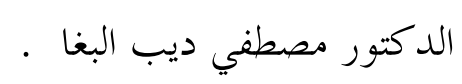

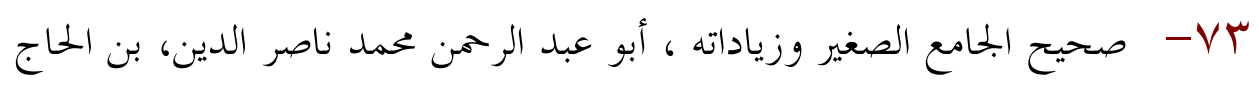

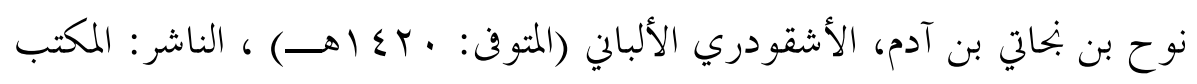
الإسلامي.

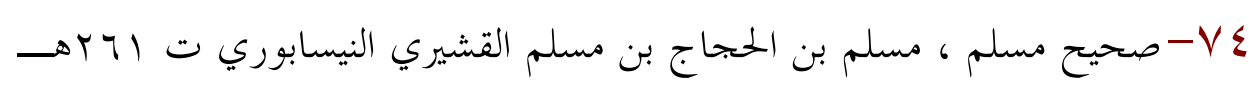

$$
\text { ) ، دار الحديث - القاهرة - الطبعة الأولي - 1991. }
$$

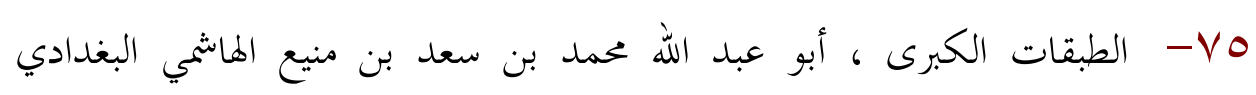

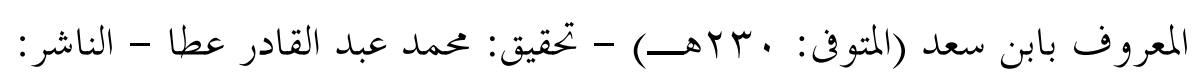

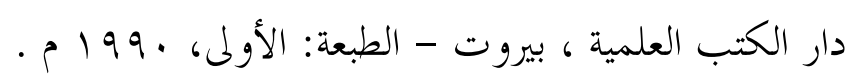




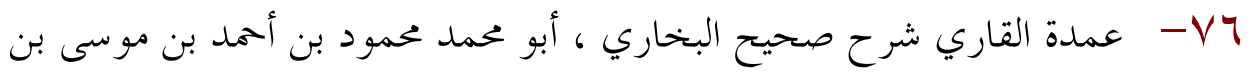

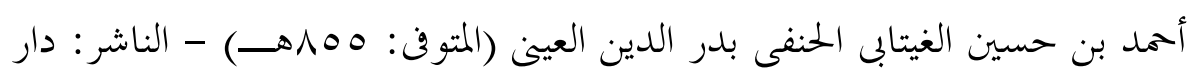

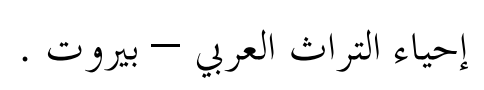

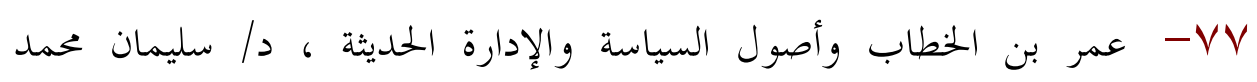

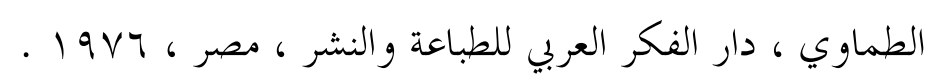

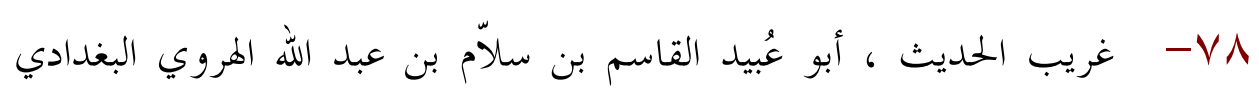

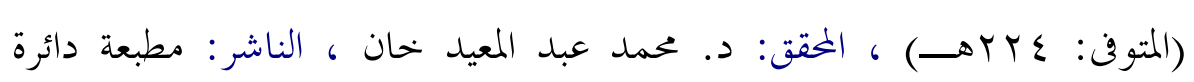

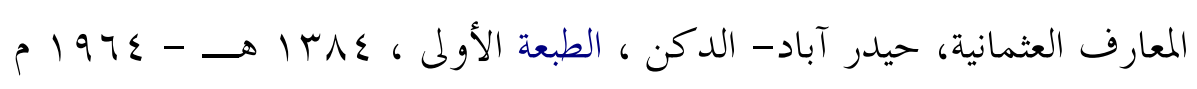



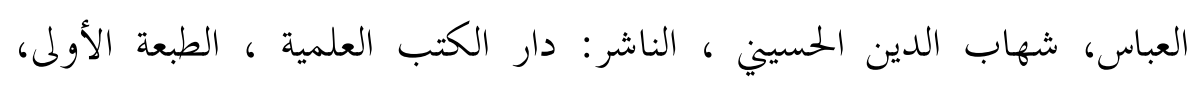
- 19190

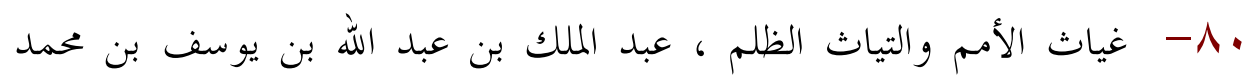

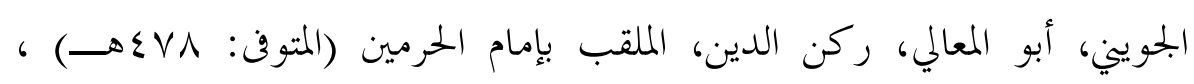

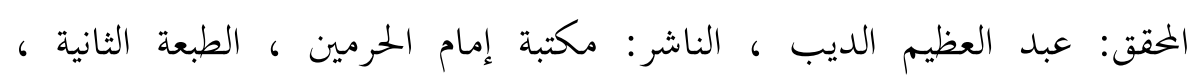
.

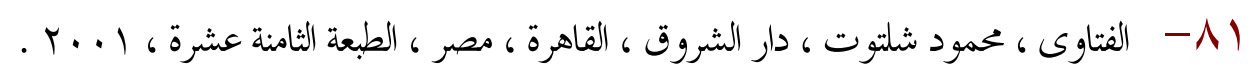

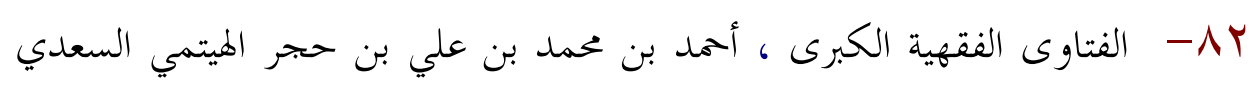

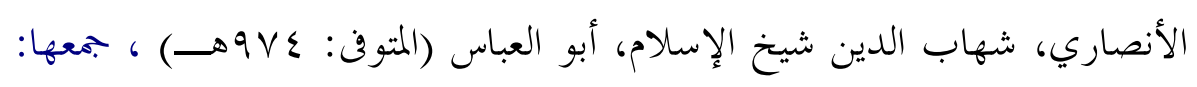

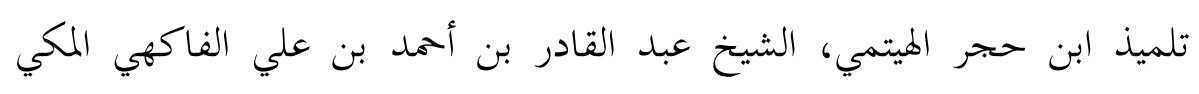

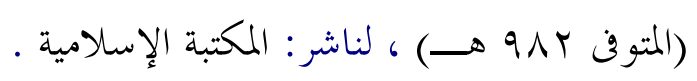

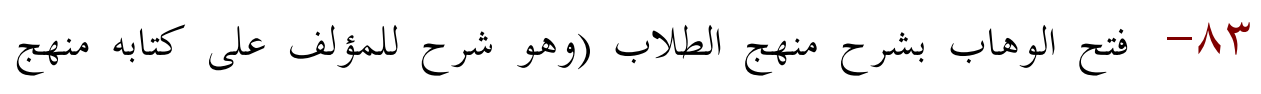

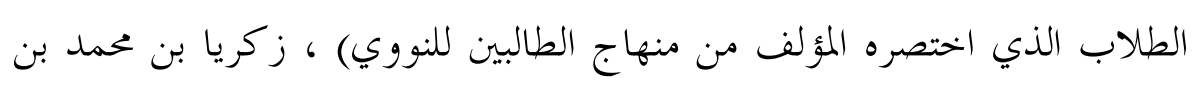


أحمد بن زكريا الأنصاري، زين الدين أبو يهيى السنيكي (المتوفن: بrوهــ) -

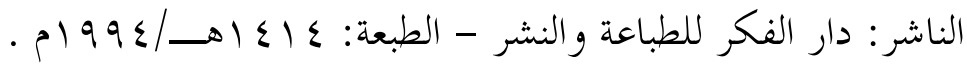

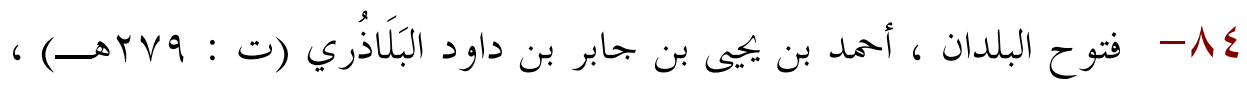

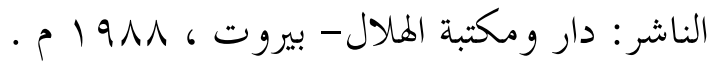

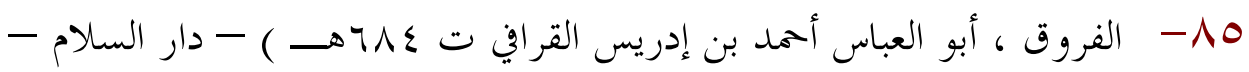

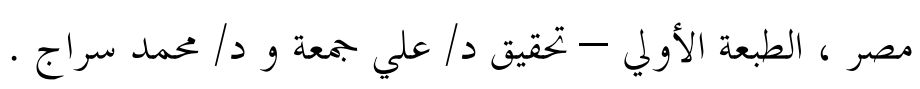

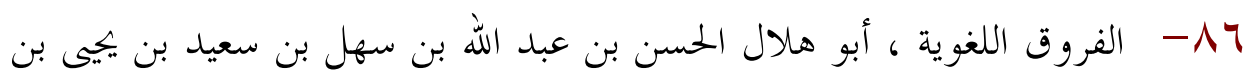
مهران العسكري (ت: 90بهـ) ، حققه وعلق عليه : محمد إبراهيم سليم ، الناشر: دار العلم و الثقافة للنشر والتوزيع، القاهرة - مصر . - فيض القدير شرح الجامع الصغير ، زين الدين محمد المدعو بعبد الرؤوف بن تاج العارفين بن علي بن زين العابدين الحدادي ثم المناوي القاهري (المتوفن:

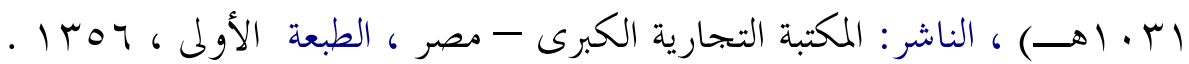

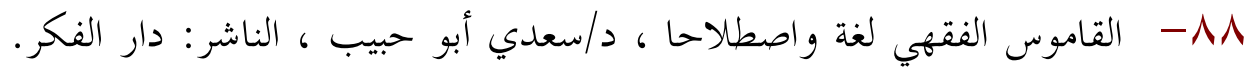
دمشق ، سورية ، الطبعة الثانية ، 1911 م م لـ

9 -1 - القاموس المحيط العلامة اللغوي بحد الدين محمد بن يعقوب الفيروز آبادي المتوفى سنة NIV هـ ، ، تحقيق: مكتب تحقيق التراث في مؤسسة الرسالة ، الناشر: مؤسسة الرسالة للطباعة والنشر والتوزيع، بيروت - لبنان ، الطبعة الثامنة ،

$$
\text { . }
$$

• 9- قواعد الأحكام في مصالح الأنام ، أبو محمد عز الدين عبد العزيز بن عبد السلام بن أبي القاسم بن الحسن السلمي الدمشقي، الملقب بسلطان العلماء

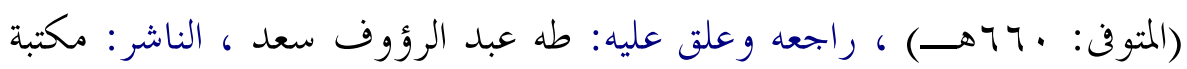

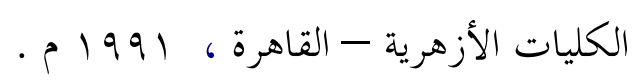


ا 9- القواعد النورانية الفقهية ، تقي الدين أبو العباس أحمد بن عبد الحليم بن عبد

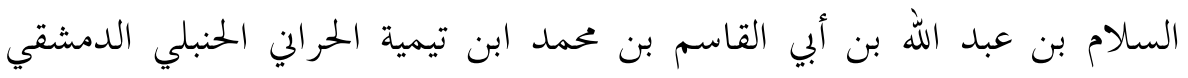

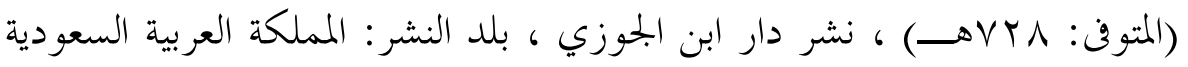

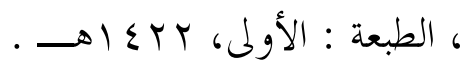

r

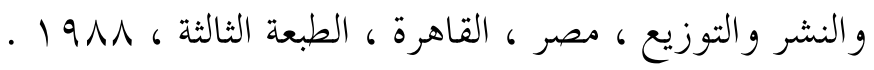

سو- لسان العرب ، لابن منظور ( محمد بن مكرم بن على، أبو الفضل، جمال

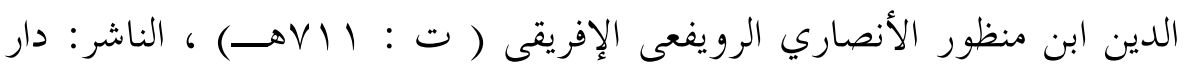

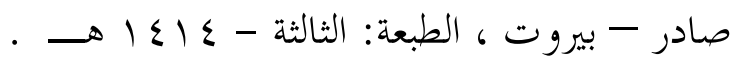

؟ 9- المبادئ العامة في النظام السياسي الإسلامي : قواعده الأساسية ، ومصادره ، والسلطات العامة فيه ، دراسة مقارنة بالنظم المعاصرة ، محمد محمد إسماعيل

فرحات ، دار النهضة العربية ، مصر ، 1991 199

90-المبسوط ، السرخسي ( أبو بكر محمد بن أحمد ت .9ءهــ ) دار المعرفة -

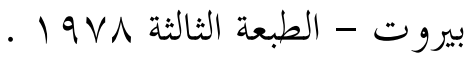

97 - 9جمل اللغة ، أبو الحسين أحمد بن فارس بن زكريا بن محمد بن حبيب

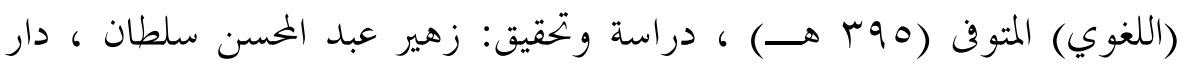

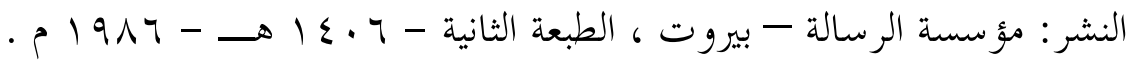

-9V

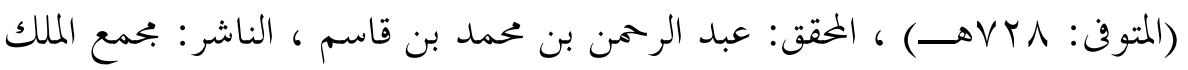

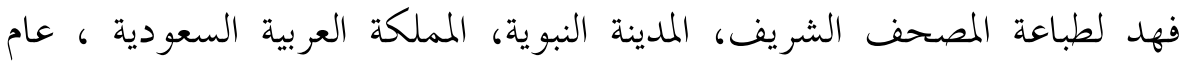

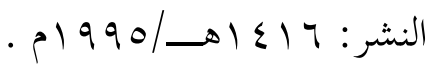

91- المحلى بالآثار ، أبو محمد علي بن أحمد بن سعيد بن حزم الأندلسي القرطبي

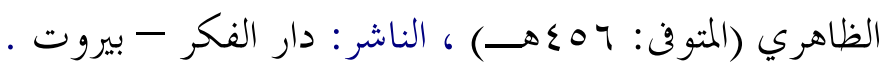

rr. 
99 - مدخل للفكر الاقتصادي في الإسلام ، د/ سعيد مرطان ، مؤسسة الرسالة ، بال

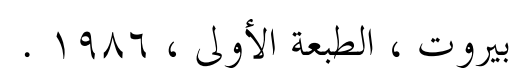

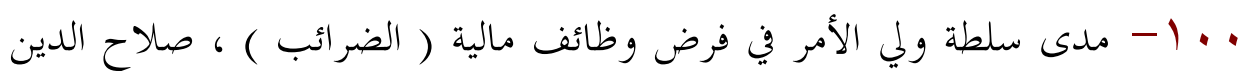

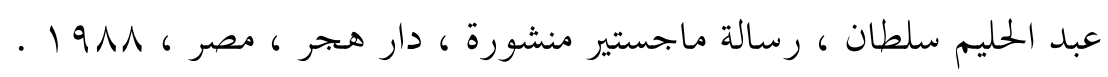

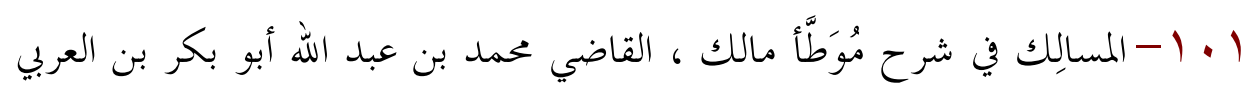

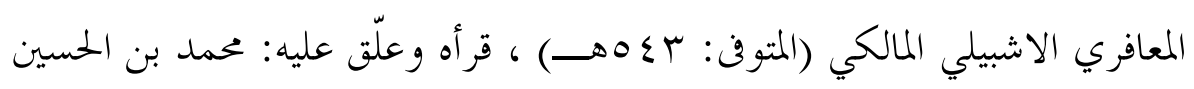

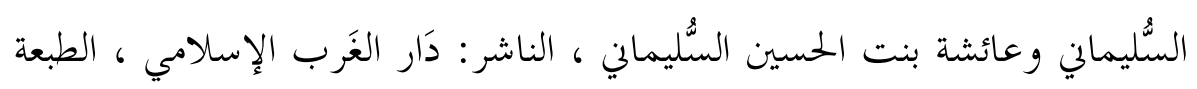

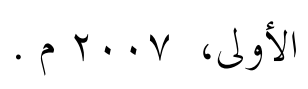

Y • ( - المعجم الوسيط ، بحمع اللغة العربية بالقاهرة (إبراهيم مصطفى / أحمد الزيات

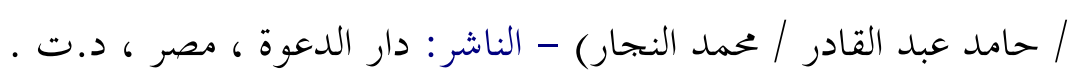

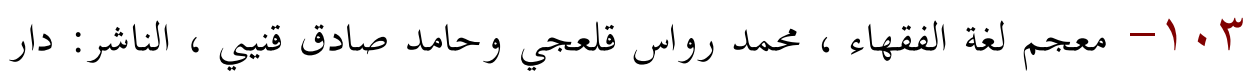

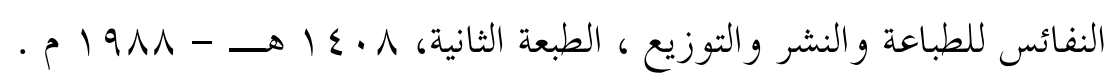

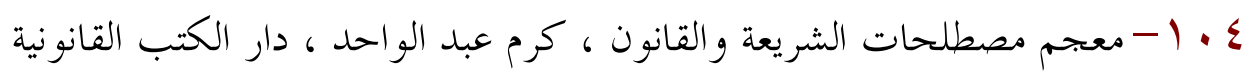
، القاهرة ، 1990 .

ه 1 - معجم مصطلحات الشريعة والقانون ، كرم عبد الواحد ، دار الكتب القانونية ، القاهرة ، 1990 .

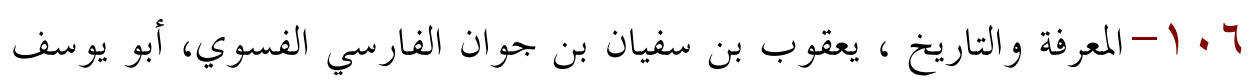

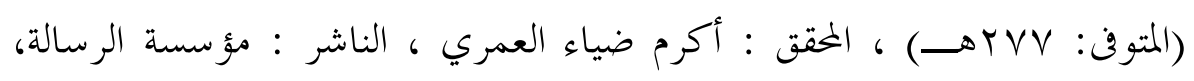

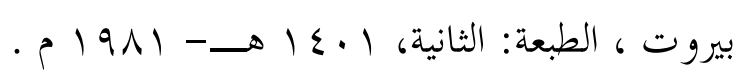

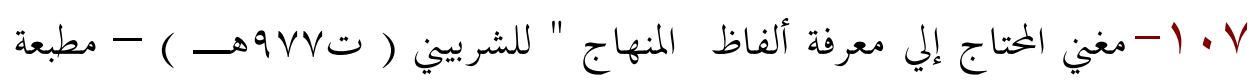

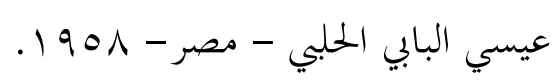


1 1 - المفردات في غريب القرآن ، أبو القاسم الحسين بن محمد المعروف بالراغب

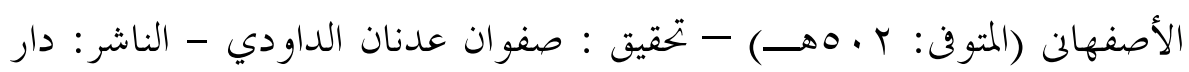

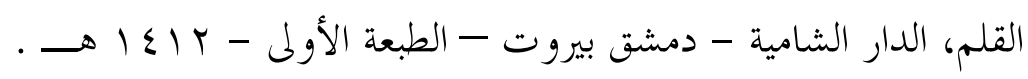
9 • 1- المفهم لما أشكل من تلخيص كتاب مسلم - المؤلف: أبو العباس أحمد بن عمر بن إبراهيم القرطبي (ت 707 هـ) - حققه وعلق عليه وقدم له: محيي الدين ديب ميستو - أحمد محمد السيد - يوسف علي بديوي - محمود إبراهيم بزال الناشر: (دار ابن كثير، دمشق - بيروت)، (دار الكلم الطيب، دمشق - بيروت)

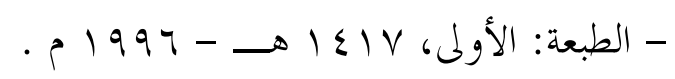
• 11-مفهوم ولي الأمر وعلاقته ببعض المفاهيم المرتبطة به في الفقه الإسلامي ،

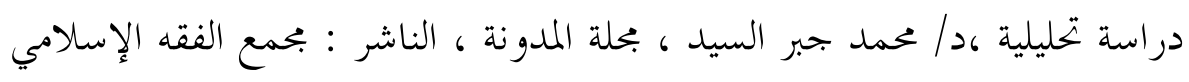
.4 .176 |11 المقاصد الشرعية وعلاقتها بالأدلة الشرعية ، د/ نور الدين بن مختار الخادمي ،

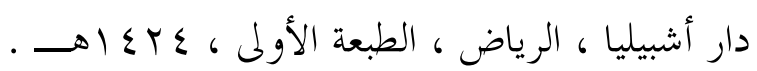
Y I (1-مقاصد الشريعة الإسلامية ، الطاهر بن عاشور ، تحقيق محمد طاهر الميساوي ،

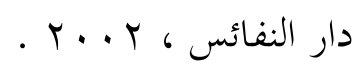

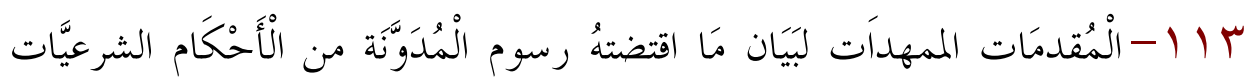

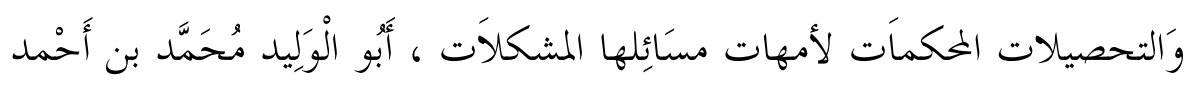

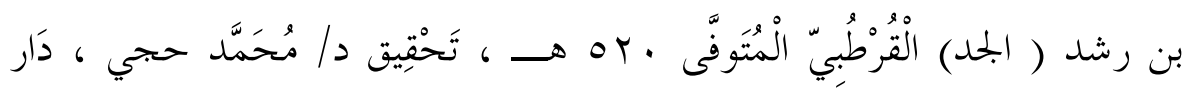

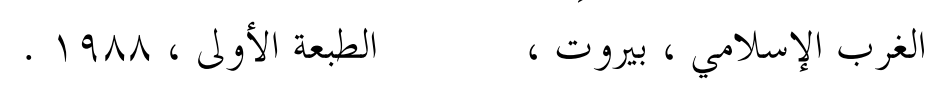

ع | (1-مناقب عمر بن الخطاب ، أبو الفرج عبد الرحمن بن أبي الحسن بن الجوزي (

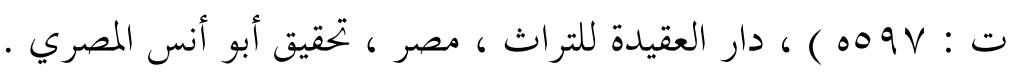


10 بن وارث التجيي القرطبي الباجي الأندلسي (المتوفى: ع عـهـ) - الناشر: مطبعة

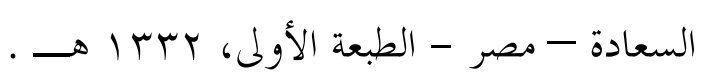

7117 مطبوعات الاتحاد الدولي للبنوك الإسلامية ، القاهرة . I V ا موسوعة الاقتصاد الإسلامي ، د/ محمد عبد المنعم الجمال ، دار الكتاب العربي

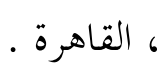

11 1 ا-مُوْسوعَة القَواعِدُ الفِقْهيَّة ، محمد صدقي بن أحمد بن محمد آل بورنو أبو

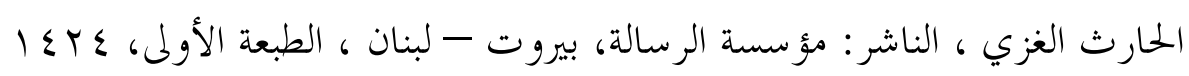

$$
\text { . }
$$

9 11 19

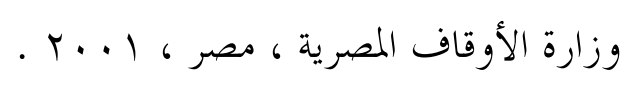

• ب ا-نظام الحكم الإسلامي مقارنا بالنظم السياسية المعاصرة ، إسماعيل البدوي ،

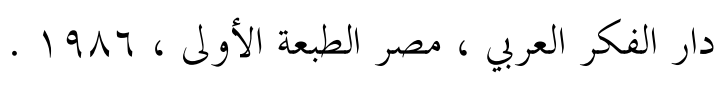

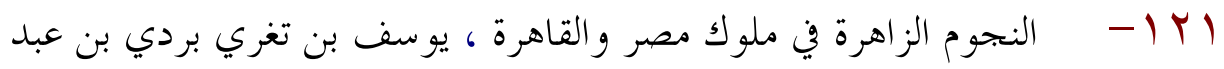

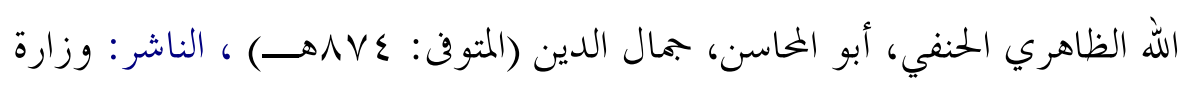

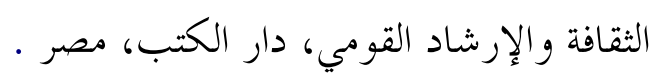

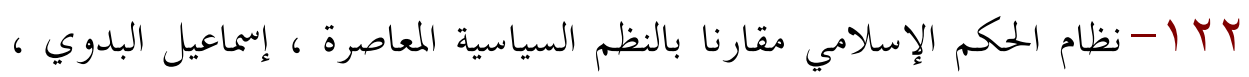

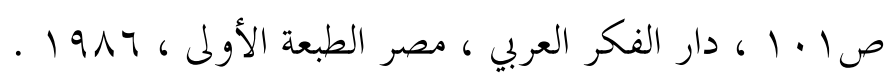
ب ا ا - النظريات السياسية الإسلامية ، د// حممد ضياء الدين الريس ، دار التراث ،

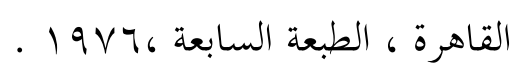
ع Y ا- النظم الإسلامية ، نشأها وتطورها ، د/صبحي الصالح ، دار العلم للملايين ، بيروت. 
0 ا ( - فاية السول شرح منهاج الوصول ، عبد الرحيم بن الحسن بن علي الإسنوي

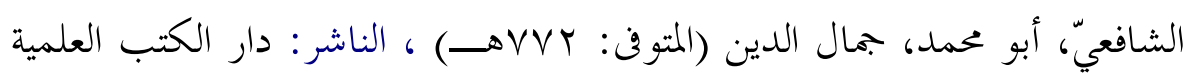

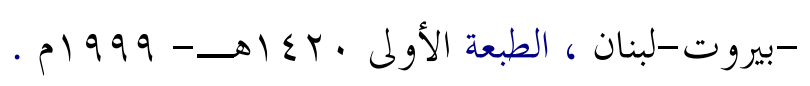

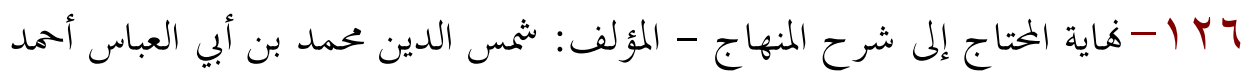

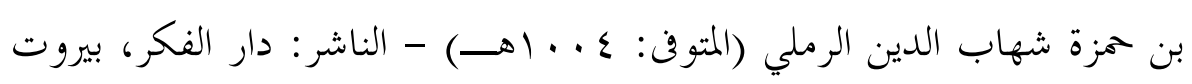

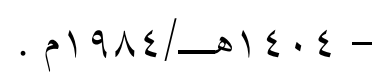

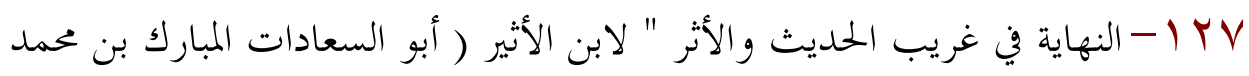

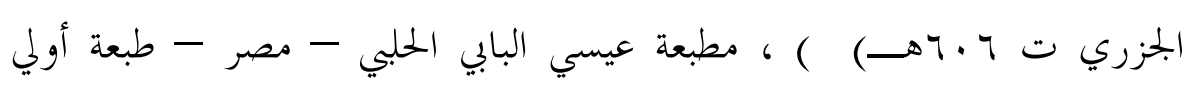

$$
.197 r
$$

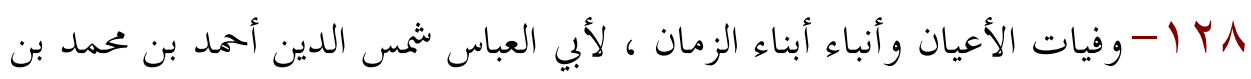

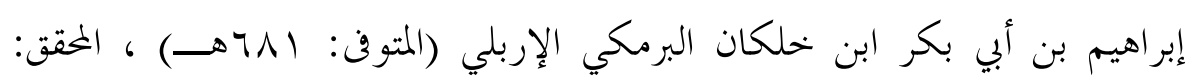

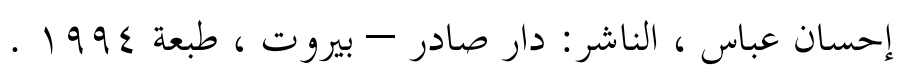

$$
\text { بو اقع الالكترونية : }
$$

https://www.marefa.org

https://humanitarian-law.org .

https://www.un.org.

.https://www.icdo.org

https://www.wfp.org

https://www.marefa.org

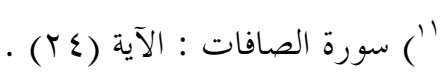

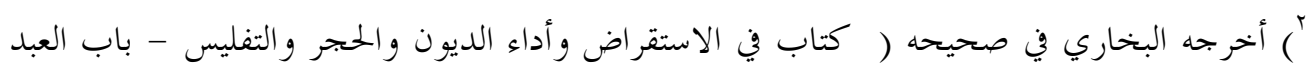

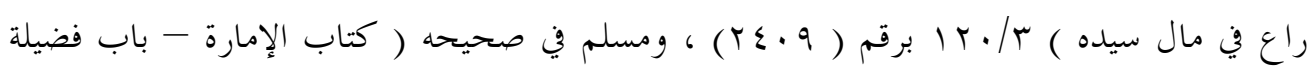




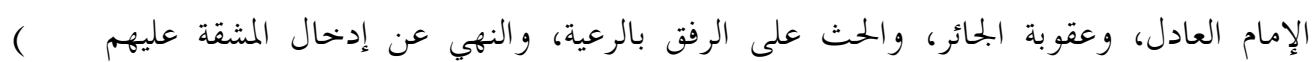

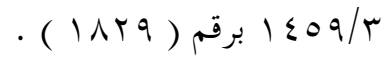

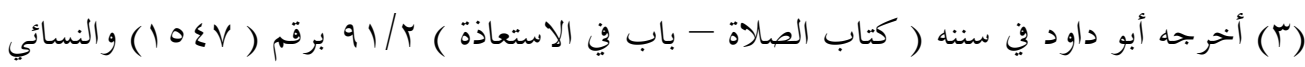

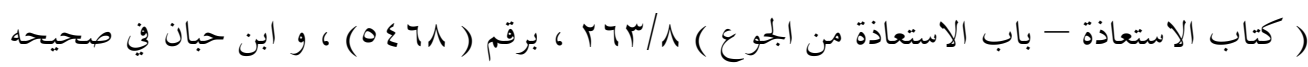

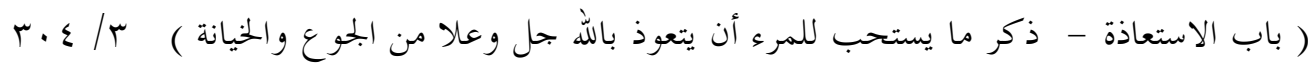

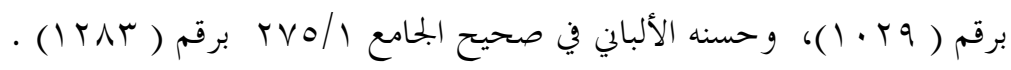

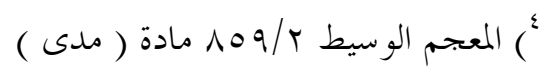

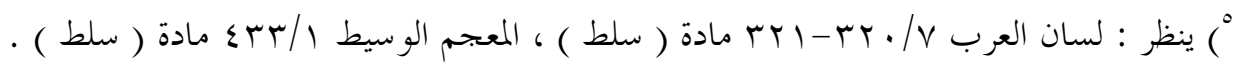

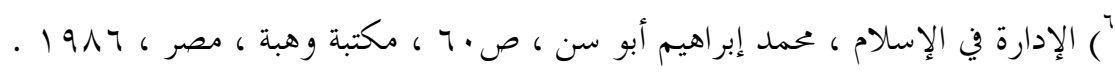

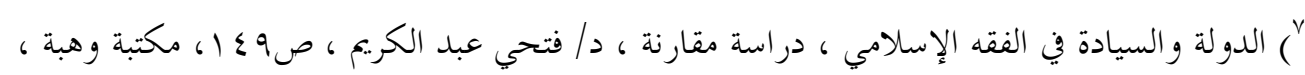
مصر ، الطبعة الثانية ، ع 191

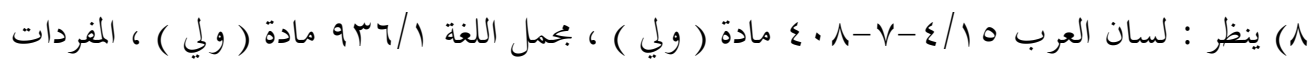

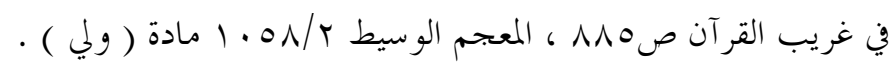
9) المعجم الوسيط /7// r مادة ( أمر ) ·') مفهوم ولي الأمر وعلاقته ببعض المفاهيم المرتبطة به في الفقه الإسلامي ، دراسة تحليلية ،د/ محمد

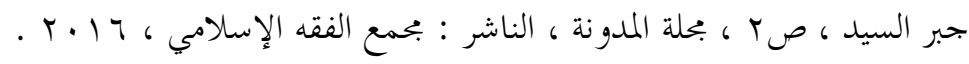
") موسوعة المفاهيم الإسلامية العامة ، ص الج ، وزارة الأوقاف المصرية ، الجلس الأعلى للشئون الإسلامية ، مصر .

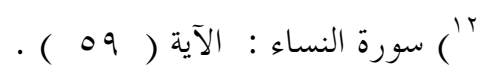

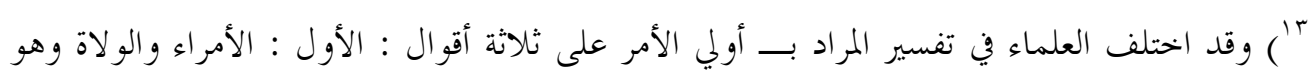

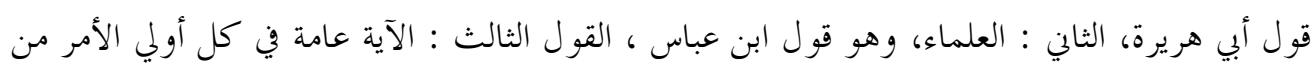


الأمراء والعلماء ، وذهب إليه ابن تيمية وابن العربي والقرطبي وابن كثير ـ ينظر : تفسير القرطبي

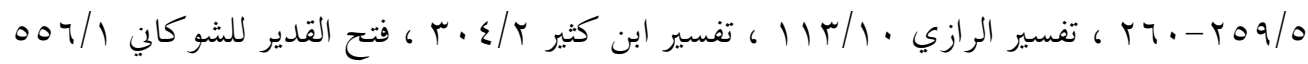

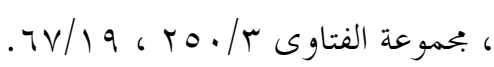

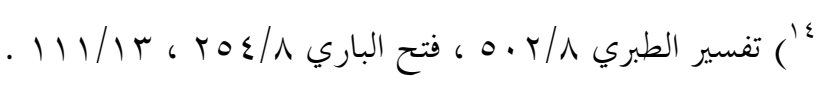

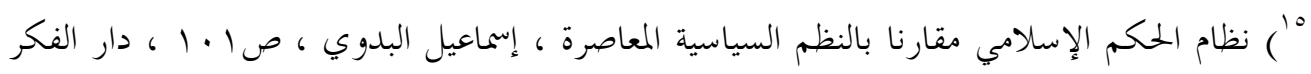

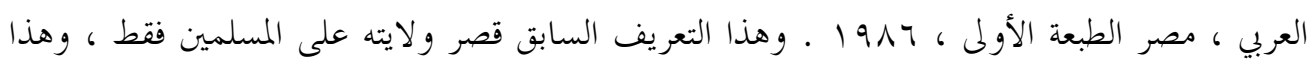

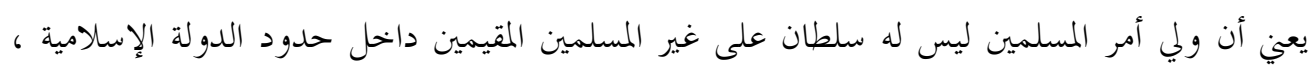

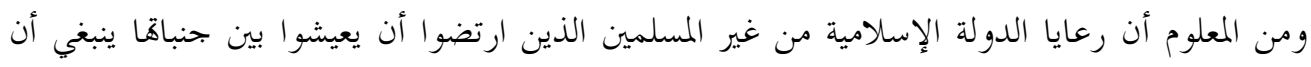

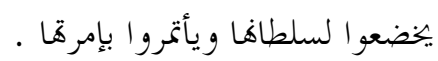

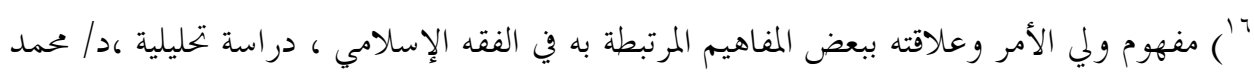
جبر السيد ، صع لما فلفظ الخلافة كان يعني رئيس الدولة الإسلامية بكل أقاليمها ، عندما كانت الدولة الإسلامية دولة

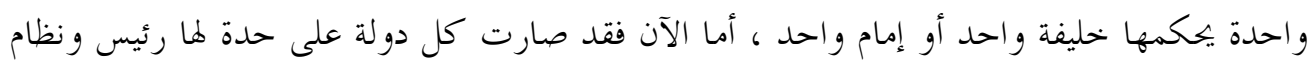

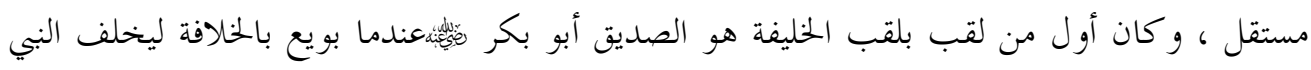

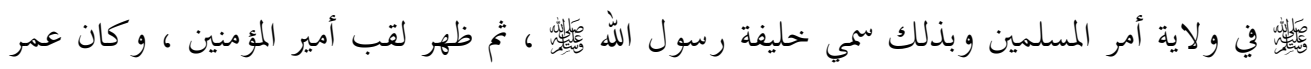

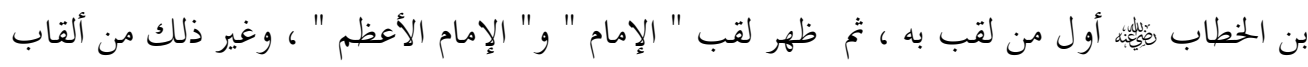

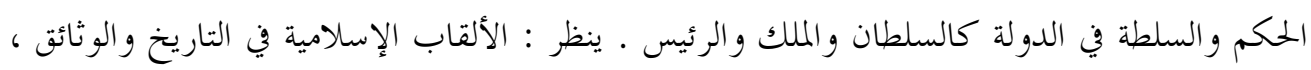

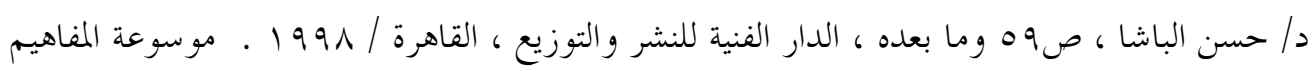

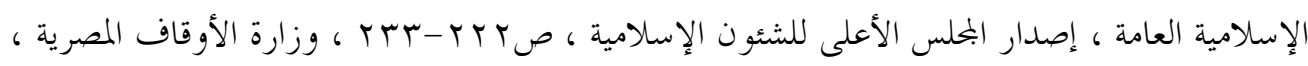

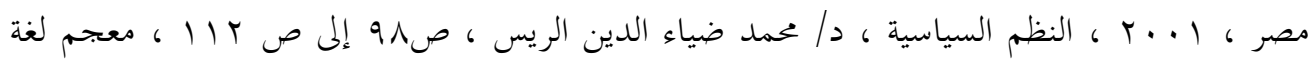

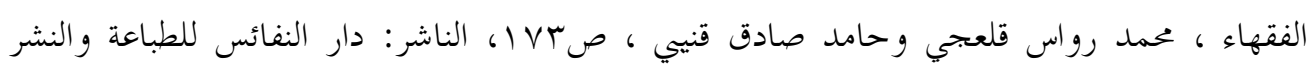

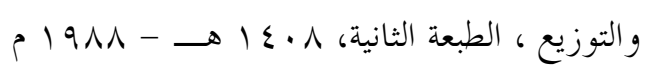

1 1^) ينظر : الخلافة ، محمد رشيد رضا ، صلا ، الزهراء للإعلام العربي - القاهرة ، ع99 199 ،

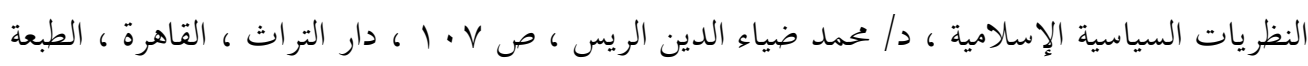

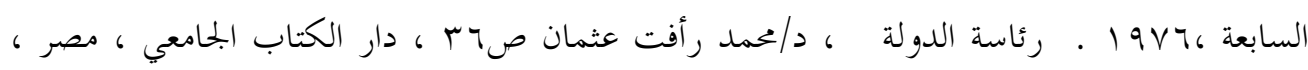




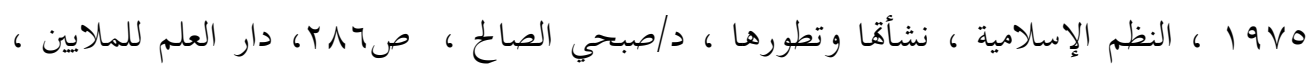
بيروت . المبادئ العامة في النظام السياسي الإسلامي : قواعده الأساسية ، ومصادره ، والسلطات العامة فيه ، دراسة مقارنة بالنظم المعاصرة ، محمد محمد إسماعيل فرحات ، ص صالب ب ، دار النهضة

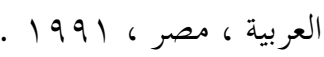

19 معجم مصطلحات الشريعة والقانون ، كرم عبد الواحد ، ص V • Y، دار الكتب القانونية ، القاهرة .19906

• · الحدود الأنيقة والتعريفات الدقيقة ، زكريا بن محمد بن أحمد بن زكريا الأنصاري، زين الدين أبو

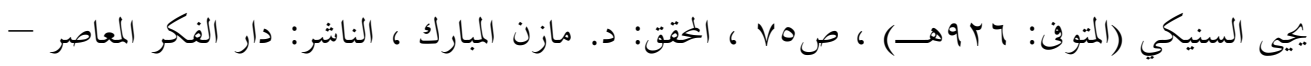

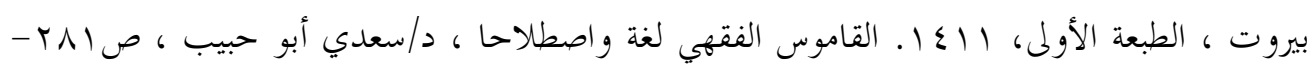
r Y r ، الناشر: دار الفكر. دمشق ، سورية ، الطبعة الثانية ، 911 ام .

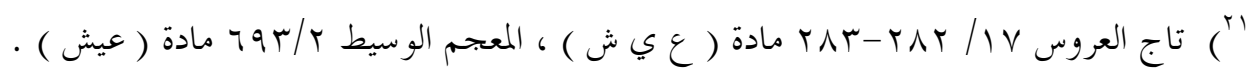

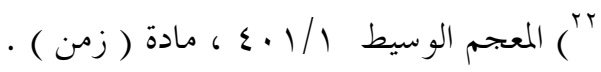

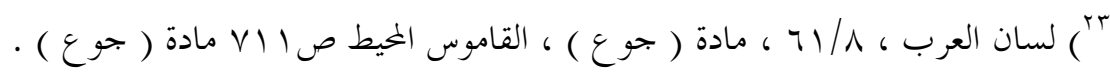

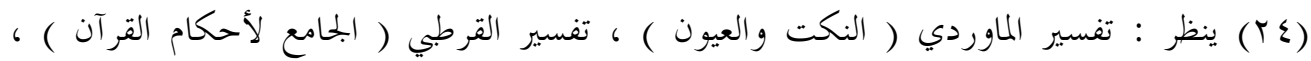

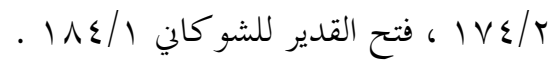

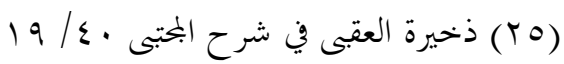

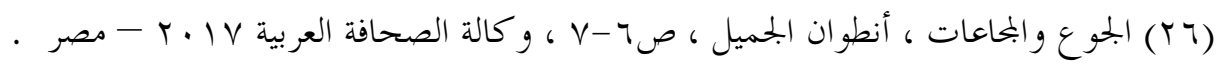
https://www.marefa.org : ينظر (TV) https://ar.guide-humanitarian-law.org/content/article/o/mj/ : ينظر (^) https://www.un.org/ar : 


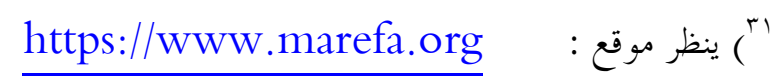

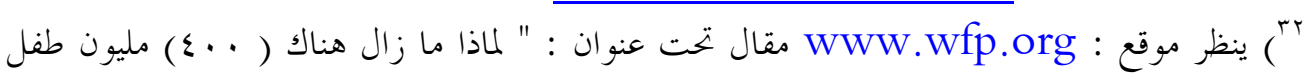
جائع

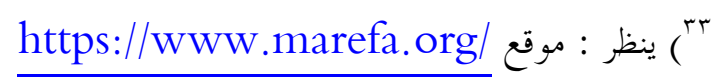

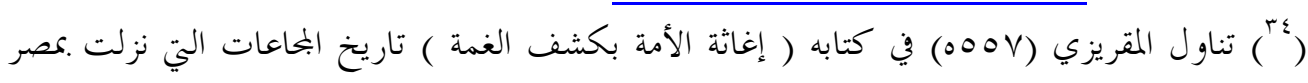

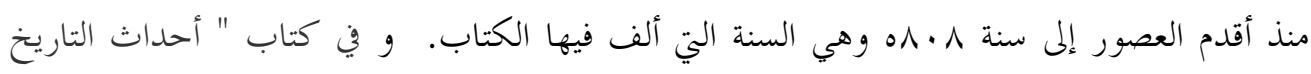

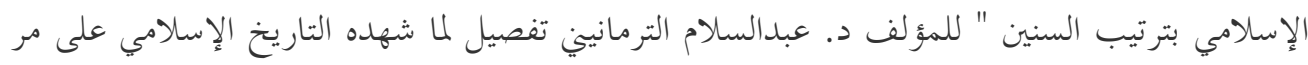

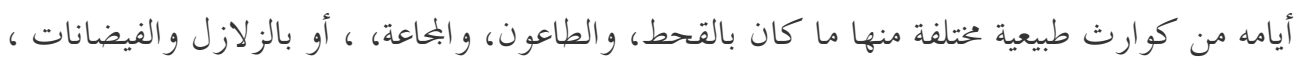

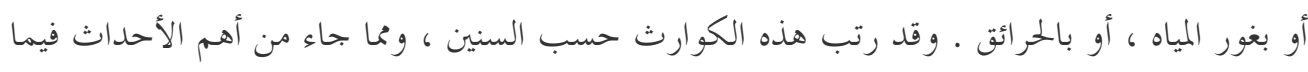

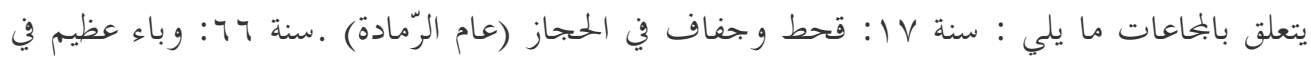

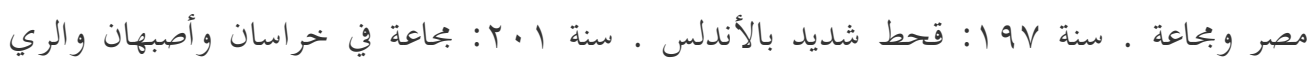

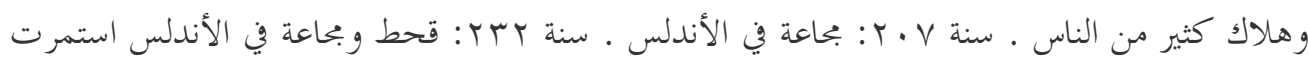

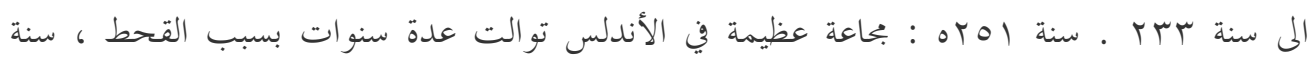
roror

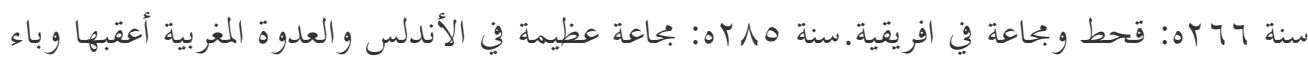

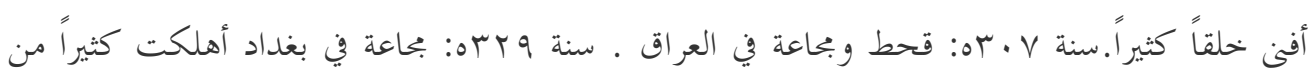

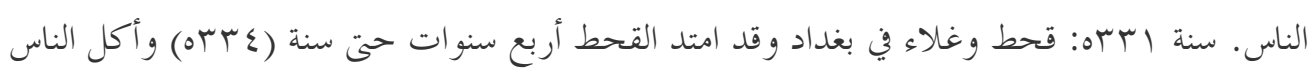

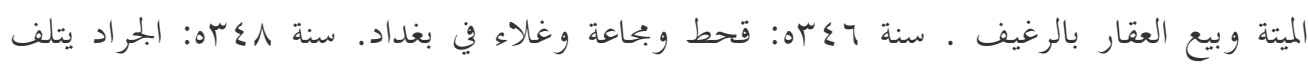

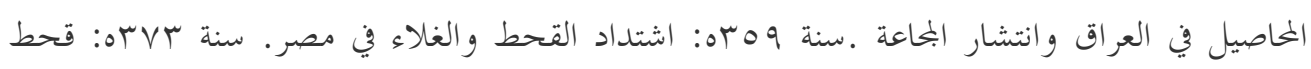

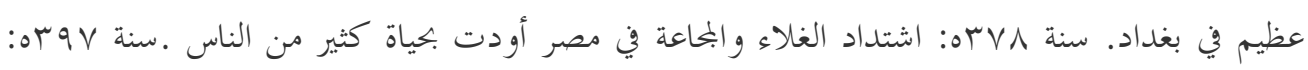

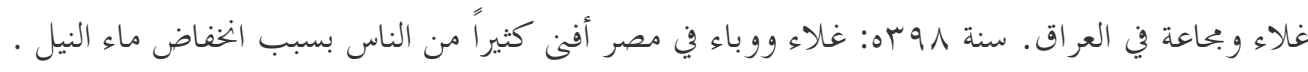

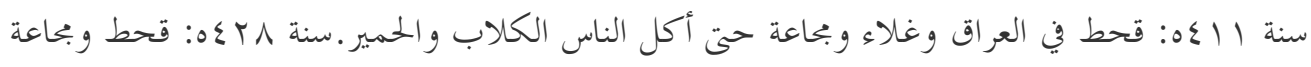

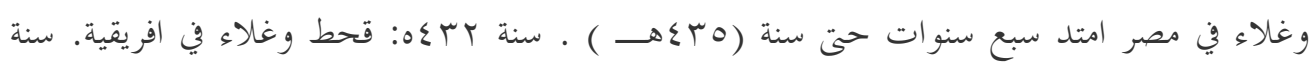

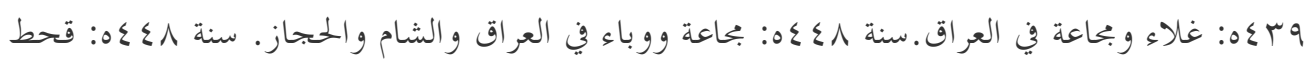


شديد في مصر. سنة .0؟ه: غلاء شديد في العراق وأكل الناس الميتة.سنة 00§ه: وباء شديد في مصر

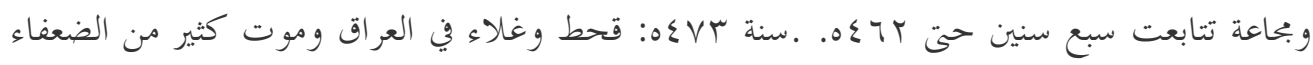
و الفقر اء.سنة و90ه: قحط وبحاعة في مصر لنقصان مياه النيل. و باء قاتل بأرض الشراة بالحجاز و اليمن. سنة ع790 قهط وبحاعة في مصر أفضت لملاك كثير من الناس. ينظر كتاب " أحداث التاريخ الإسلامي بترتيب السنين " للمؤلف د. عبدالسلام الترمانيني - دار طلاس - دمشق .

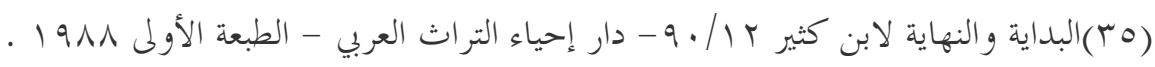

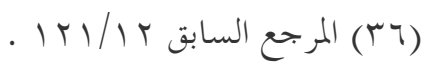

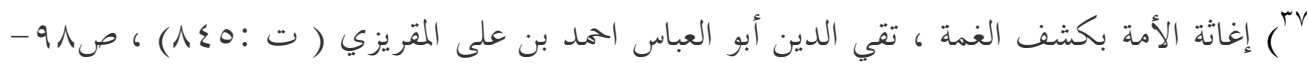
99، تحقيق د/ كرم حلمي فرحات ، الناشر : عين للدر اسات والبحوث الإنسانية والاجتماعية ، القاهرة

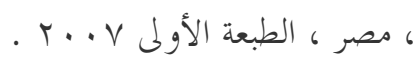
(†^) في كتابه القيم : "الإفادة والاعتبار في الأمور المشاهدة والحو ادث المعاينة بأرض مصر" ، و وفي ذكره لوقائع هذه البحاعة المفجعة التى شاهد آثارها بعينيه يقول عبد اللطيف البغدادي ص rه : " ولو أخذنا نقصٌٌ كل ما نرى ونسمع لوقعنا في التهمة أو في الهذر، وجميع ما حكيناه مما شاهدناه ، لم نتقصَّده ولا لا تتبعنا مظانَه ، و إنّما هو شيء صادفناه انتفاقا ، بل كثيرا ما كنت أفٌُّ من رؤيته لبشاعة منظره " .

(ج) ينظر : الإفادة والاعتبار في الأمور المشاهدة والحوادث المعاينة بأرض مصر ، عبد اللطيف بن يوسف بن محمد بن علي البغدادي، موفق الدين، ويعرف بابن اللباد، وبابن نقطة (المتوفن: وجا7هـ) ،

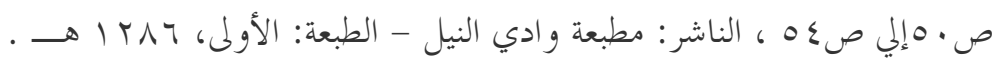

• ع) معجم السفر ، صدر الدين، أبو طاهر السِّفَي أحمد بن محمد بن أحمد بن محمد بن إبراهيم سِلَفَه

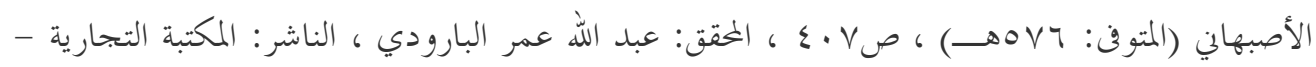
مكة المكرمة مك .

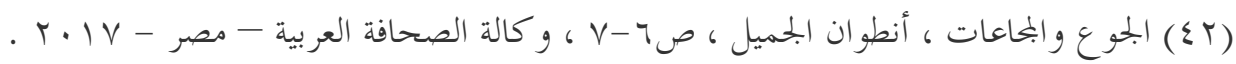




\section{؟r إغاثة الأمة بكشف الغمة ، ص^و}

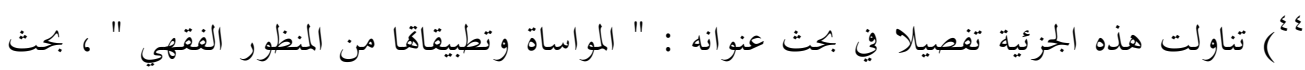

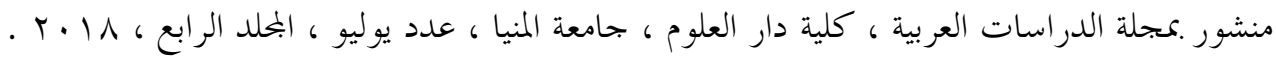
0؛ و الخليفة هو الإمامُ الذي ليس فوقه إمام ، والإمام هو من يتولى رياسة المسلمين وحكمهم ، ويسوسهم ، ويحفظ عليهم أمرهم ، و الراعي : كل من ولي أمرا بالحفظ والسياسة ، كالملك ، والأمير، والحاكم ، والرعية : عامة الناس الذين عليهم

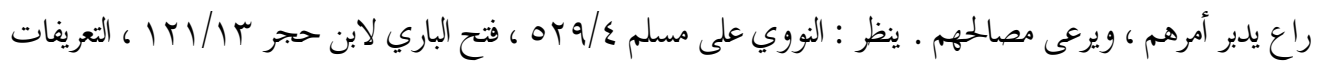

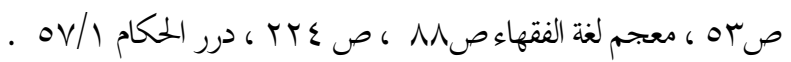

جـ ينظر : الأحكام السلطانية ، أبو الحسن علي بن محمد بن محمد بن حبيب البصري البغدادي،

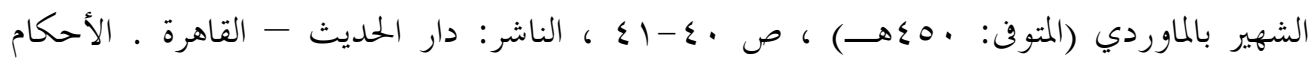

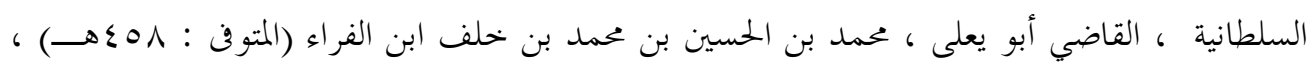
صم ץ ، صححه وعلق عليه : محمد حامد الفقي ، الناشر : دار الكتب العلمية - بيروت ، لبنان ،

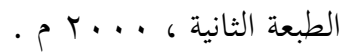

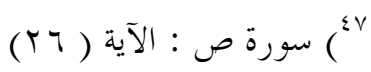

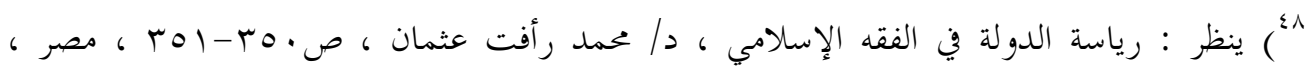
1980 9؛ ينظر : تراث الخلفاء الراشدين، د/ صبحي محمصاني ، صعَبا وما بعدها ، دار العلم للملايين -

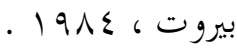

•) ينظر : التكافل الاجتماعي ، الشيخ محمد أبو زهرة ، ص07 ، الاقتصاد الإسلامي أسس ومبادئ

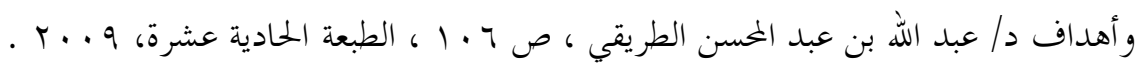

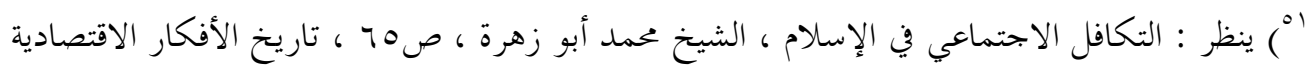

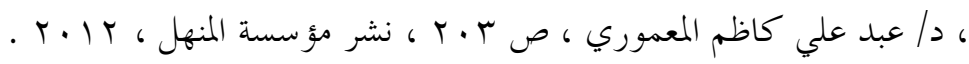
ro) غياث الأمه و التياث الظلم ، عبد الملك بن عبد الله بن يوسف بن محمد الجمويني، أبو المعالي، ركن صن

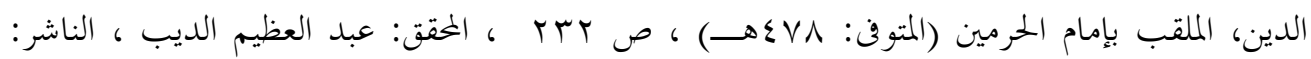

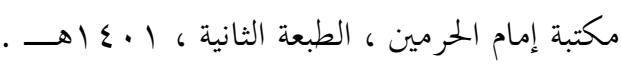
r 
؛ ينظر : القواعد الكبرى ( قواعد الأحكام في مصالح الأنام ) العز بن عبد السلام 1/ع | | .

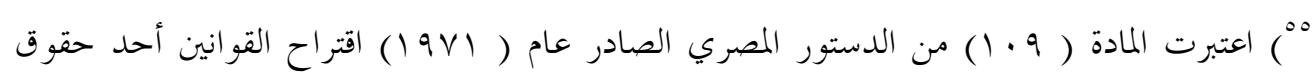
رئيس الجمهورية ، و في المادة (107 (1) جعل اقتراح القوانين اختصاصا مشتركا بين الرئيس والحلكومة ،

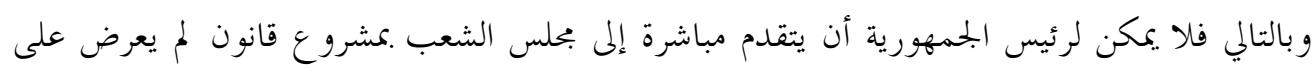

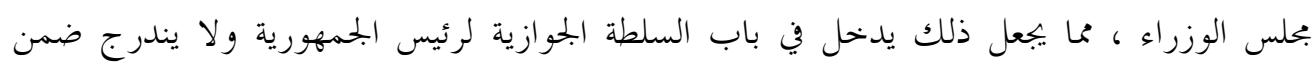

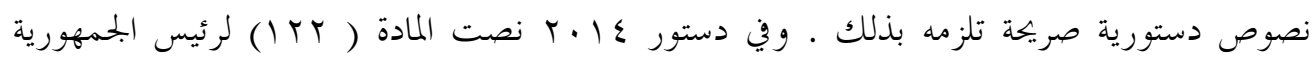
و بحلس الوزراء ، ولكل عضو في بحلس الشعب اقتراح القوانين ، ويحال كل مشروع قانون مقدم من

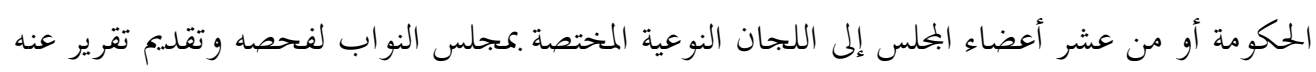
إلى البحلس · ونصت المادة (TM IT) على : لرئيس الجمهورية حق إصدار القوانين أو الاعتر اض عليها .

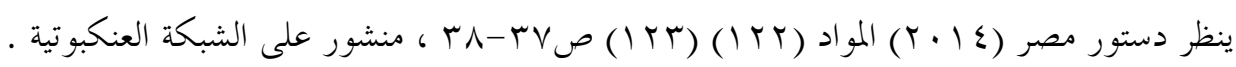

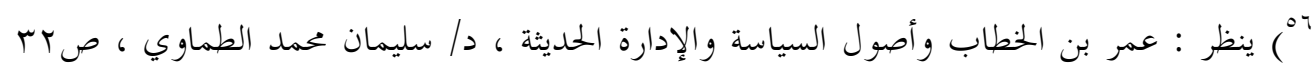

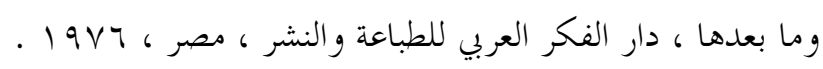

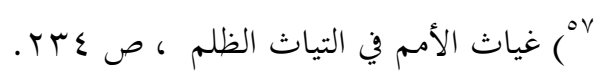

10) المو اساة وتطبيقاها من المنظور الفقهي ، أحمد جمعة ، بحث منشور بمجلة الدراسات العربية ، كلية

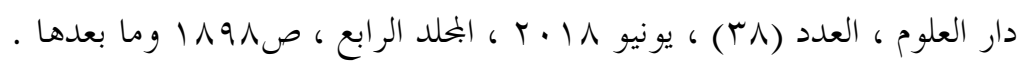
9ه ينظر :خطة الشريعة الإسلامية في ضمان الحاجات الأساسية لكل فرد ، دم/ فهد بن حمود العصيمي ، صع V ، بحث منشور على الشبكة العنكبوتية دون أية بيانات .

• ج) تنظيم الإسلام للمجتمع ، الشيخ محمد أبو زهرة ، صل حـ (، طبعة دار الفكر العربي ، القاهرة .

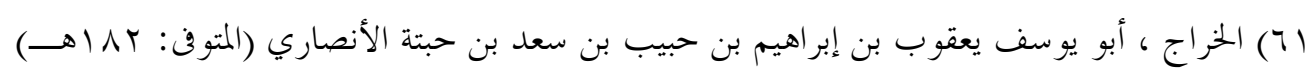
، صو با ، تحقيق : طه عبد الرعوف سعد ، سعد حسن محمد ، المكتبة الأزهرية للتراث ، القاهرة .

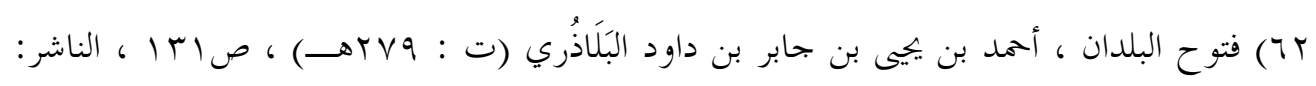

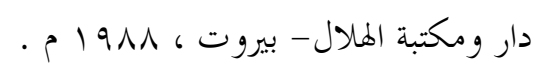

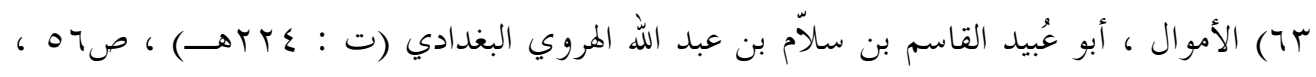

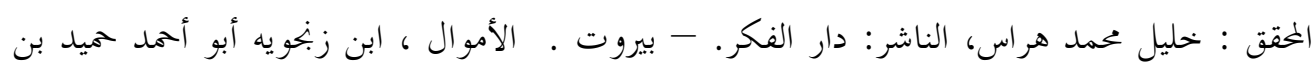

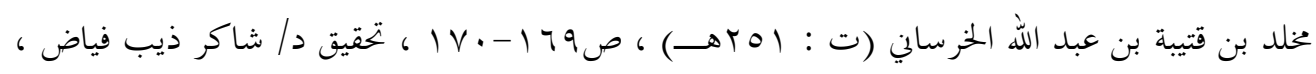

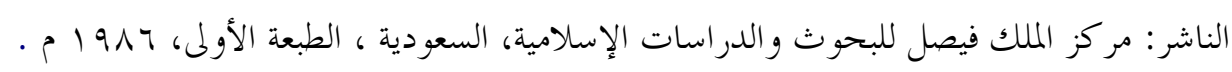




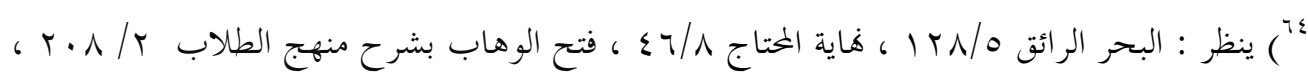

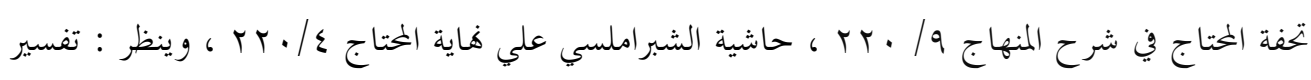

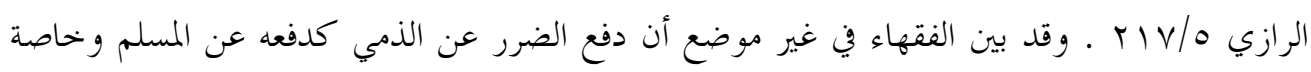

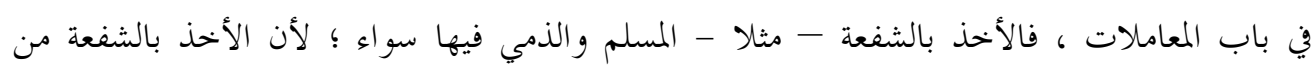
المعاملات وهم في ذلك يستوون بالمسلمين والمقصود دفع ضرر سوء البماورة وحاجة الذمي إلى ذلك بك بكابك

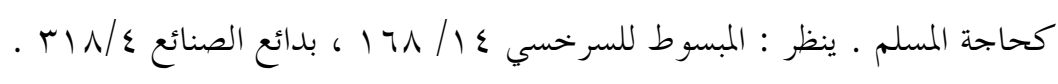

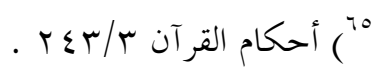
بT) ينظر في تفصيل المسألة وأدلة كل فريق : الحرية الاقتصادية وتدخل الدولة في النشاط الاقتصادي ، دـ

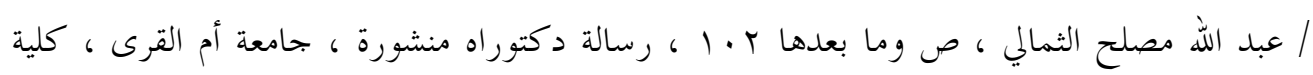
الشريعة و الدراسات الإسلامية ، 919 ( ، مدى سلطة ولي الأمر في فرض وظائف مالية ( الضرائب )

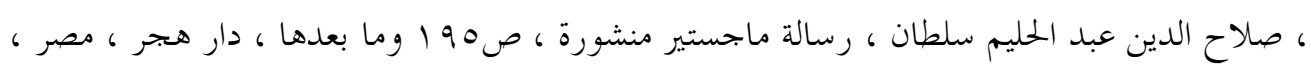

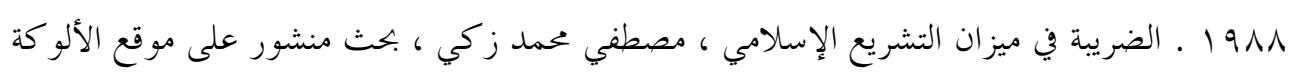

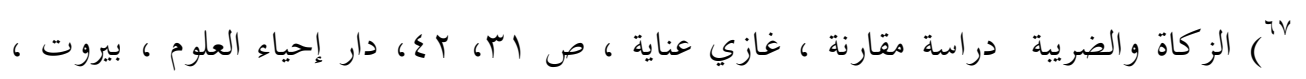

^آ الحرية الاقتصادية وتدخل الدولة في النشاط الاقتصادي ، د / عبد الله مصلح الثمالي ، صب • 1 .

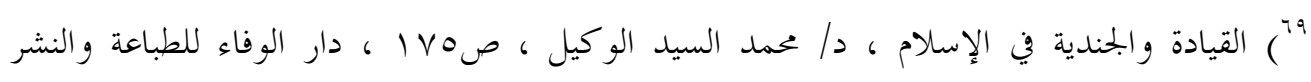

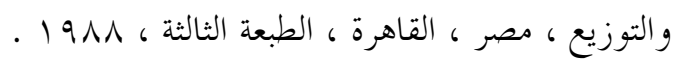

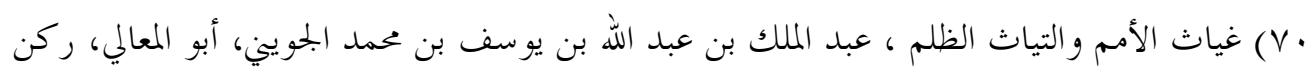

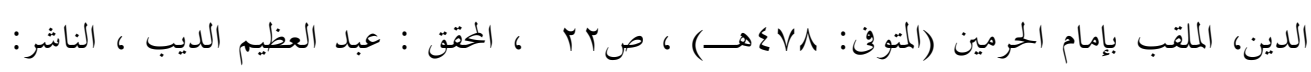

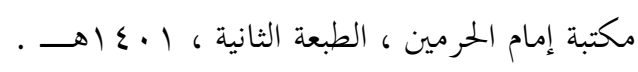

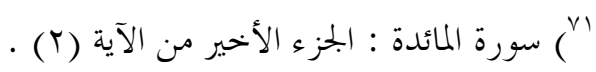

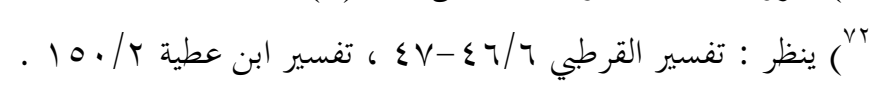

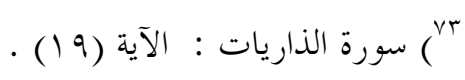

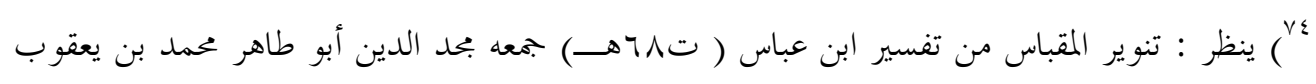

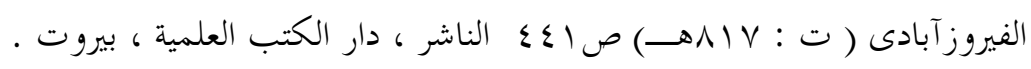

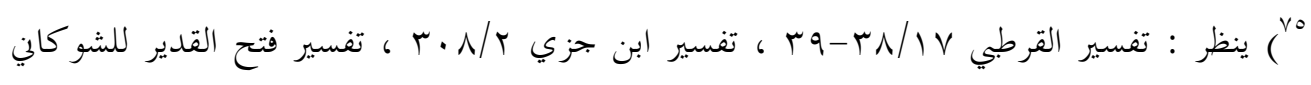
. $10 / 0$ 


$$
\begin{aligned}
& \text { ) تفسير البحر المحيط OV }
\end{aligned}
$$

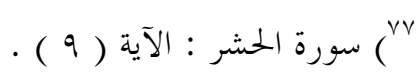

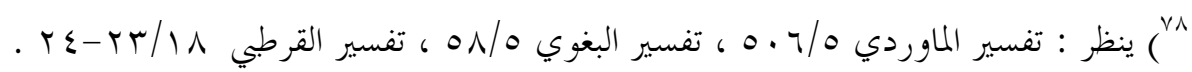

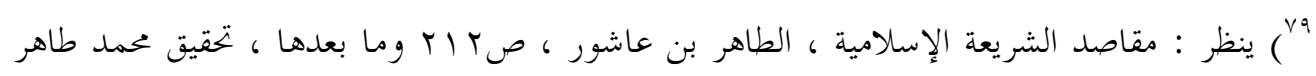

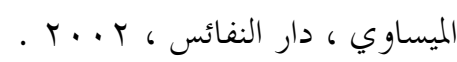

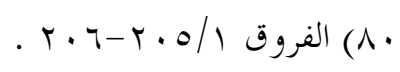

( ) ينظر : أصول الاقتصاد الإسلامي ، د/ رفيق المصري ، صبم ، دار القلم ، دمشق ، الطبعة

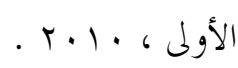

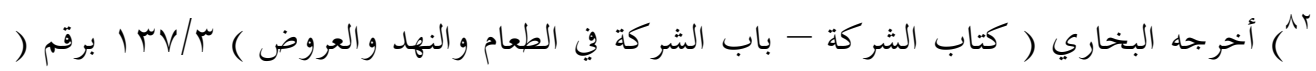

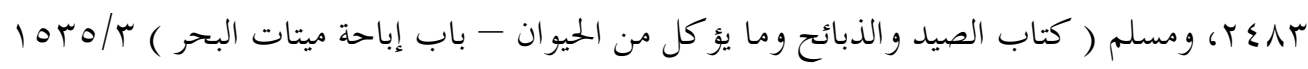

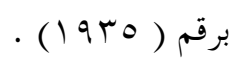

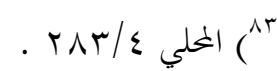

£^) حديث سلم سيأتي لاحقا . و الاحتثاء من حثا يكثو حثوا، و حثى يمثي حثيا إذا حفن حفنة . عمدة

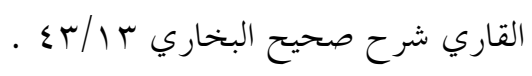

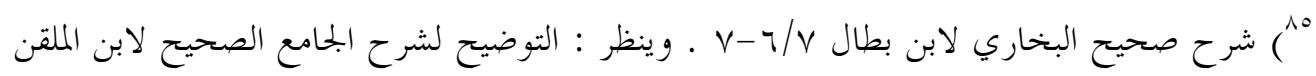
or/17 IT/T التمهيد

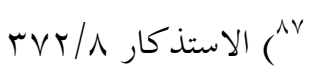

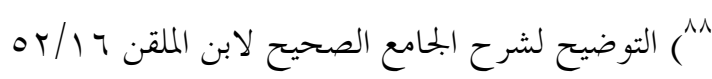

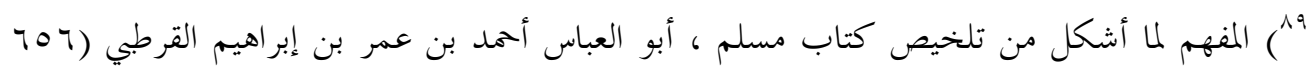

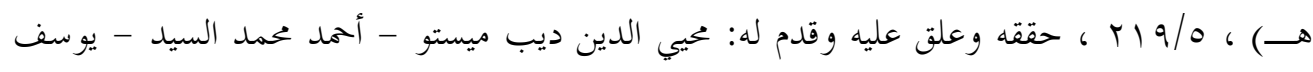
علي بديوي - محمود إبراهيم بزال ، الناشر: (دار ابن كثير، دمشق - بيروت)، (دار الكلم الطيب،

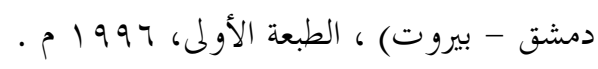

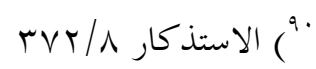

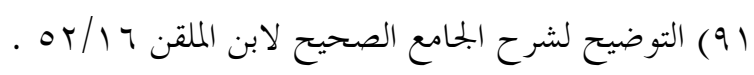

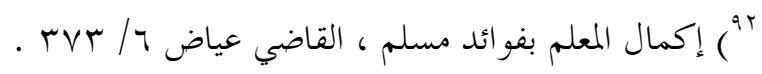


بو ) أخرجه الآجري في الشريعة ( باب ذكر دلائل النبوة مما شاهده الصحابة ) ع/N10 1 -970

$$
\begin{aligned}
& \text { برقم ( ) ع (1. ) }
\end{aligned}
$$

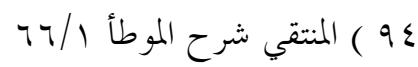

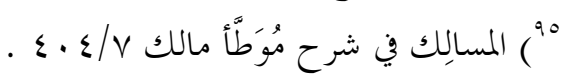

ج9 ) أخرجه البخاري في صحيحه ( كتاب الشركة - باب الشركة في الطعام والنهد والعروض )

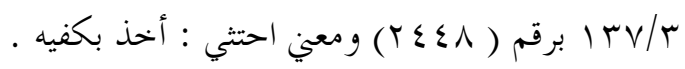
9V) أخرجه مسلم في صحيحه ( كتاب الحدود - باب استحباب خلط الأزواد إذا قلت، والمؤاساة فيها . (IVYq) (r) (r) (

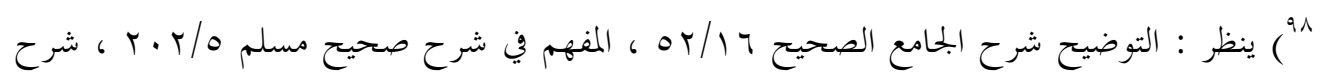

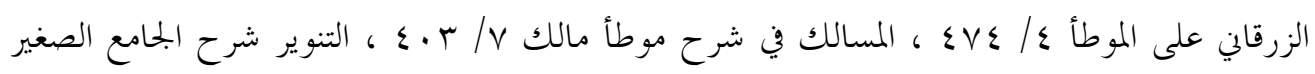

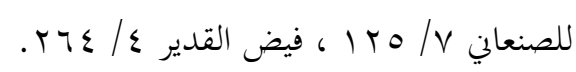

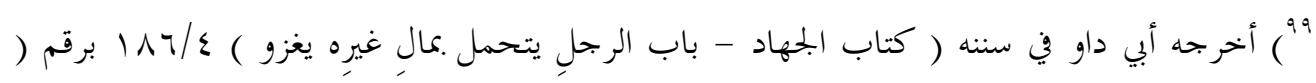

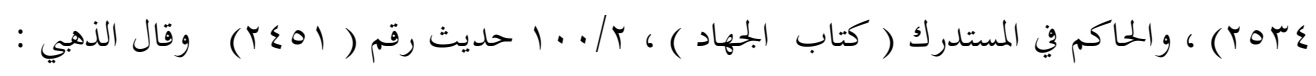

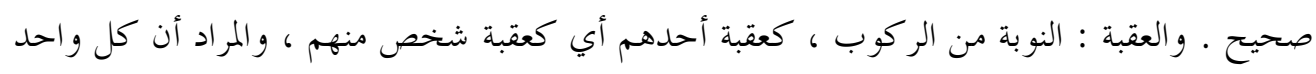
من أصحاب الظهور حكمه في الانتفاع بظهره كحكم الشركاء المشتركين في منفعة الظهر لا يستأثر عنهم بر كوب . · . . (1) شرح سنن أبي داود لابن رسلان ( أبي العباس أحمد بن حسين بن علي بن رسلان المقدسي

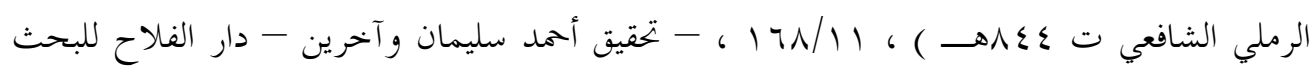

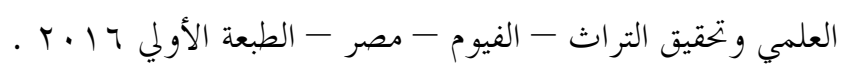

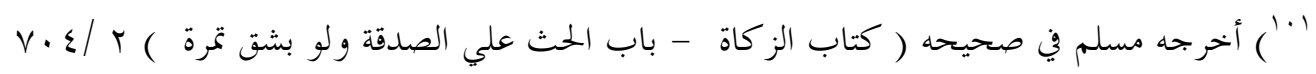

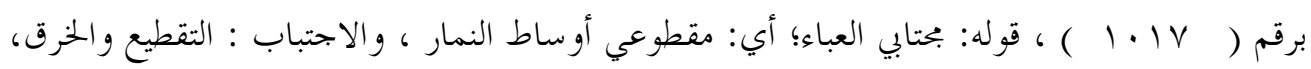

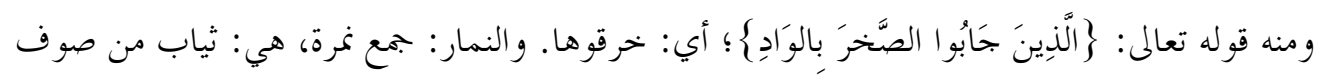

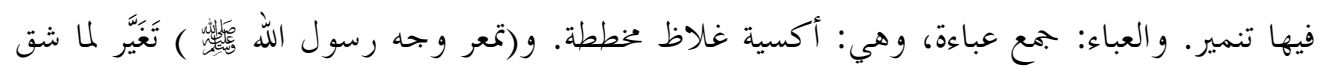

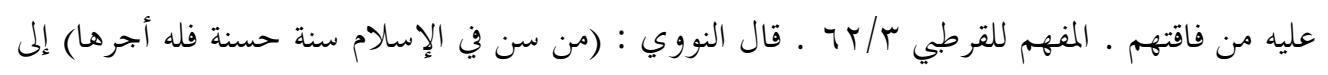
آخره فيه الحثث على الابتداء بالخيرات، وسن السنن الحسنات، و التحذير من اختراع الأباطيل 
و المستقبحات، و سبب هذا الكلام في هذا الحديث أنه قال في أوله: فجاء رجل بصرة كادت كفه تعجز عنها، فتتابع الناس، و كان الفضل العظيم للبادي هذا الخير، و الفاتح لباب هذا الإحسان .

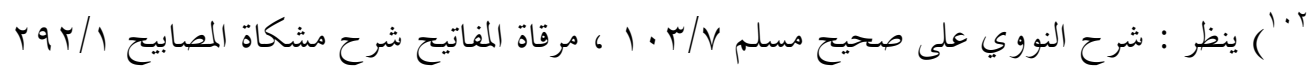

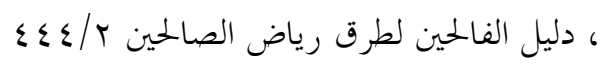

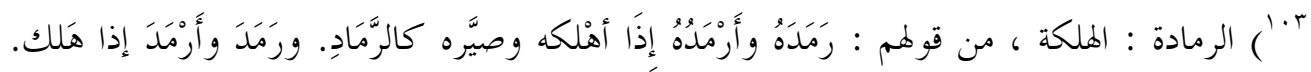

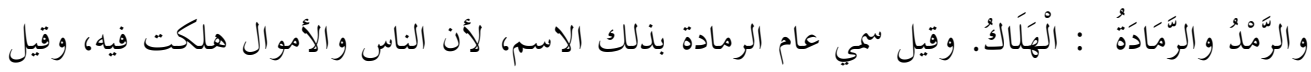
هي الجدب: تتابع النظر فتبصر الأرض والشجر، مثل لون الرمادة ، لأن الأرض اسودت بسبب قلة

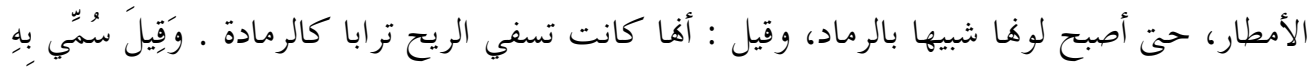

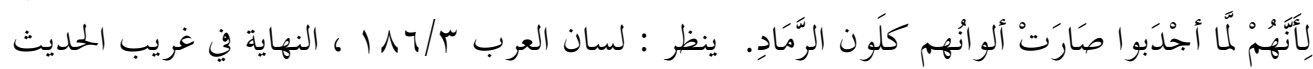

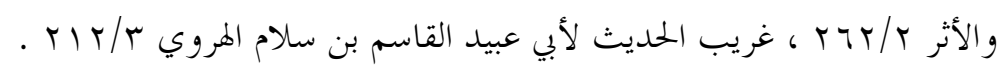

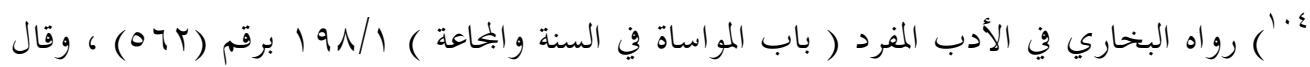

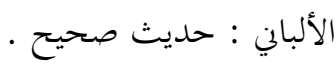

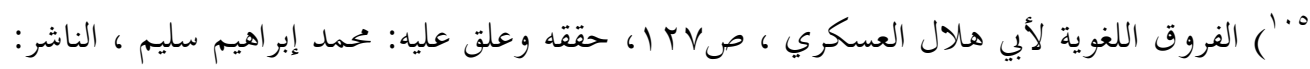

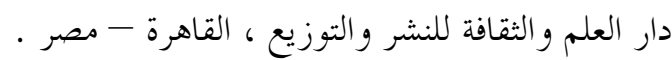

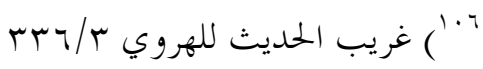

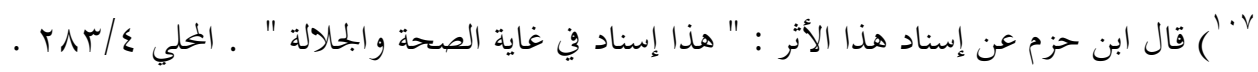

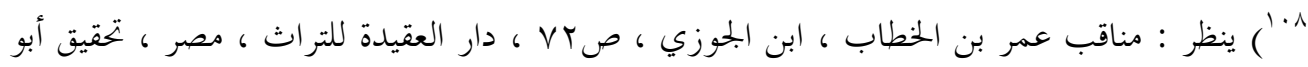

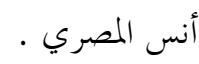

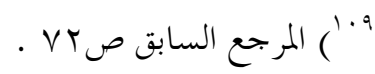
•"') موسوعة الاقتصاد الإسلامي ، د// محمد عبد المنعم الجمال ، صر بrم ، دار الكتاب العربي ،

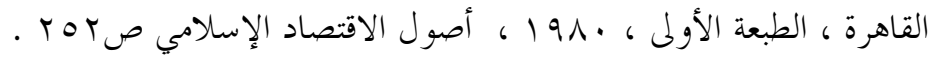

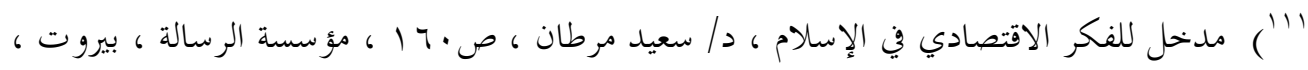
الطبعة الأولى ، 1917 . 191

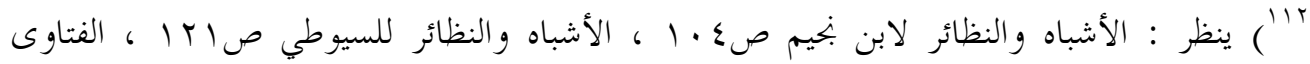

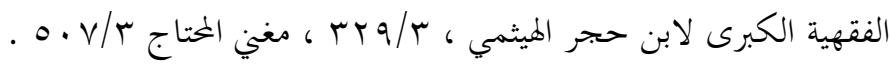

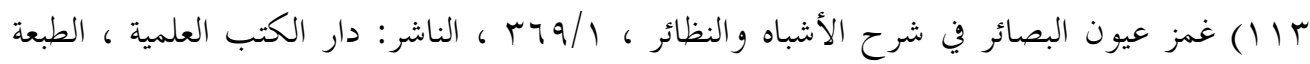
الأولى، 


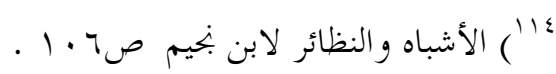

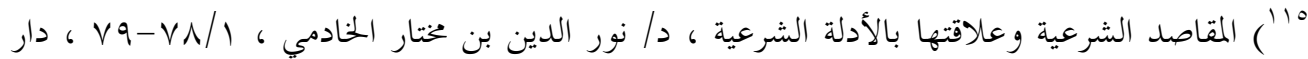

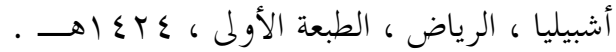

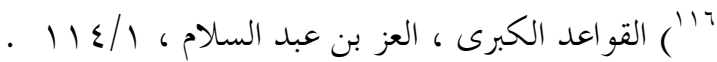

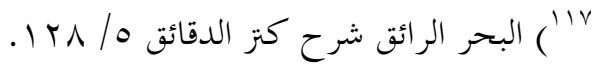

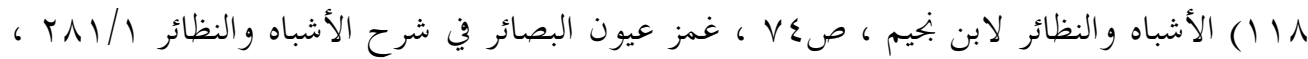

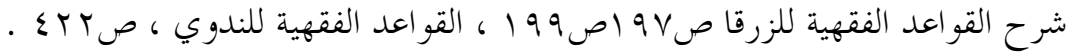

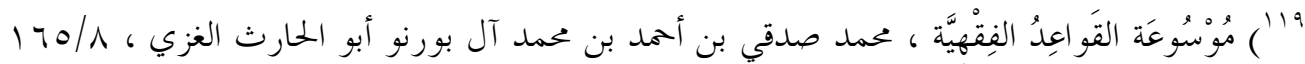

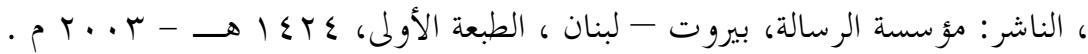

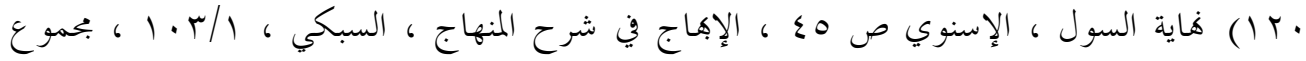

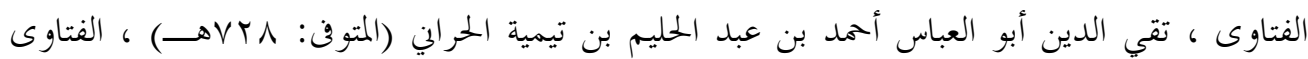
•

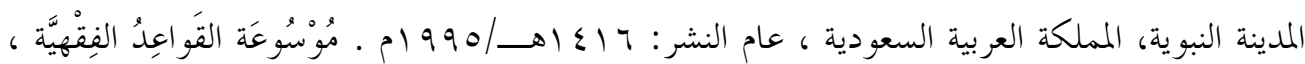

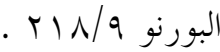

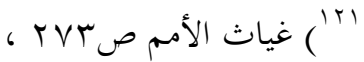

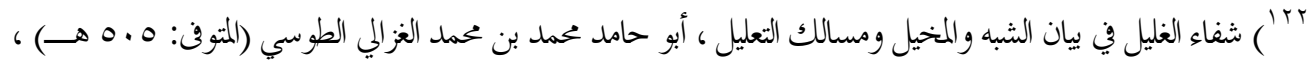

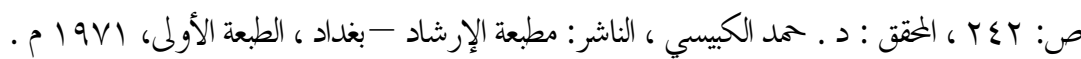
. r $1 /$ / \& الملى

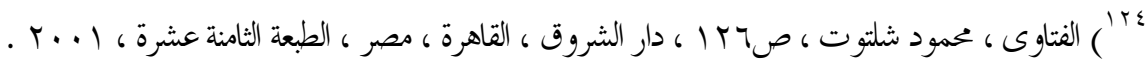

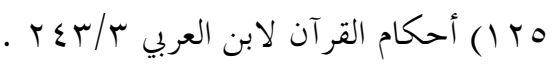

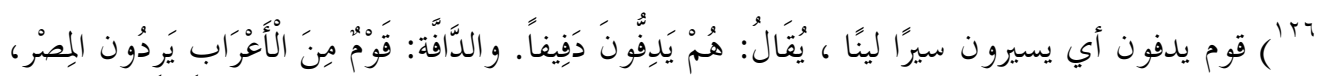

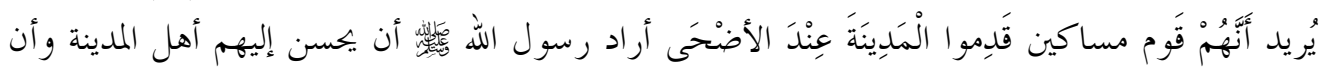

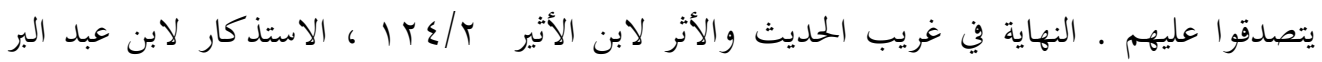
. $r$ Tr/O Vrا أخرجه مسلم في صحيحه ( كتاب الأضاحي - باب النهي عن أكل لحوم الأضاحي فوق ثلاث

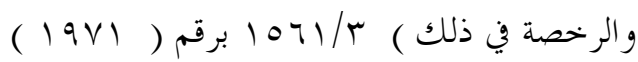




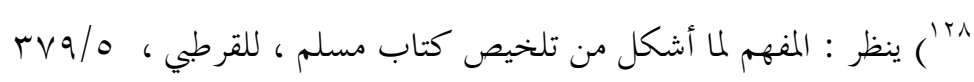

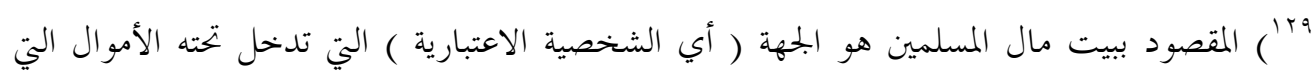

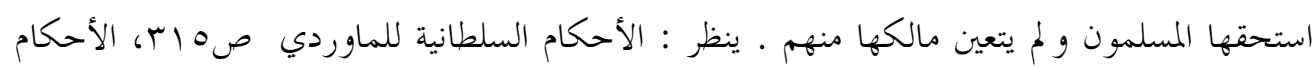

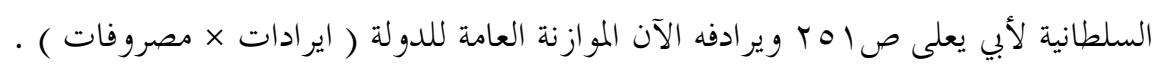

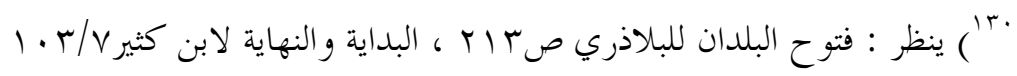

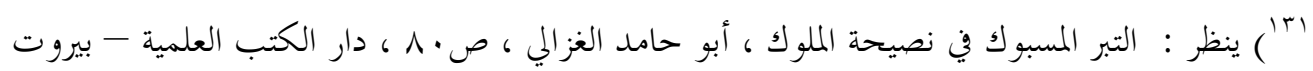

$$
\begin{aligned}
& \text { - الطبعة الأولى الى التير المدبوك } 1911 .
\end{aligned}
$$

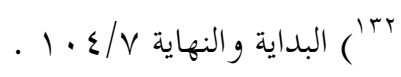

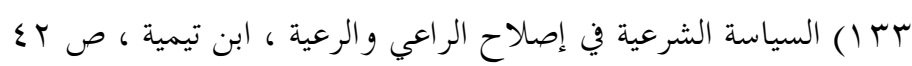

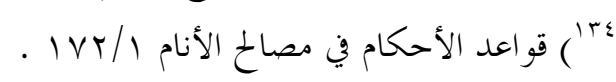

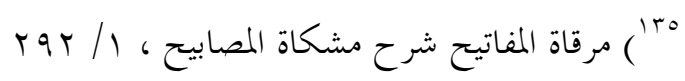

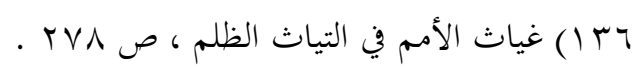

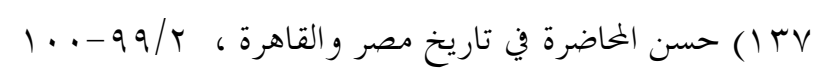

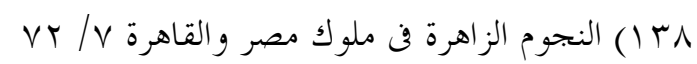
90/r

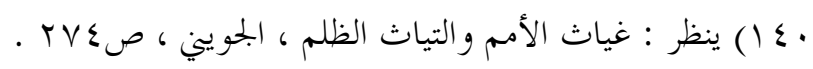

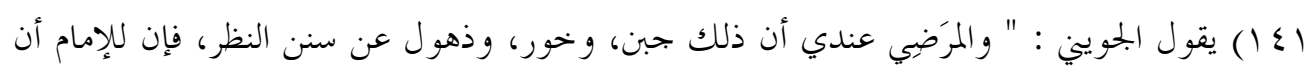

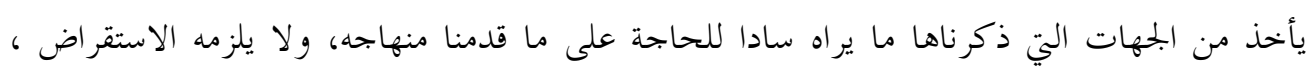

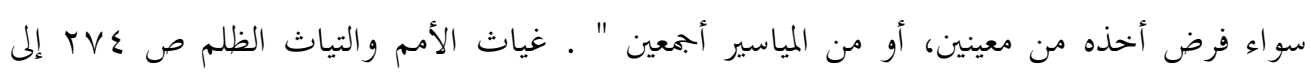
صTVY

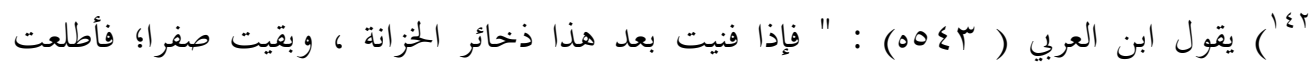

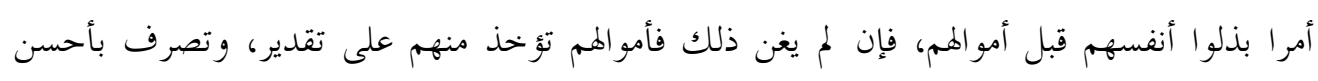

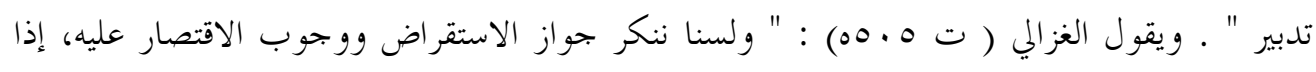

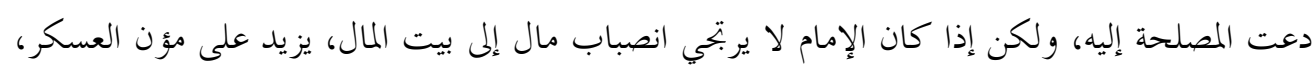

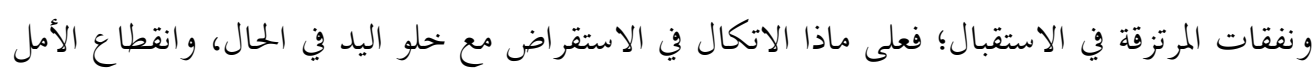

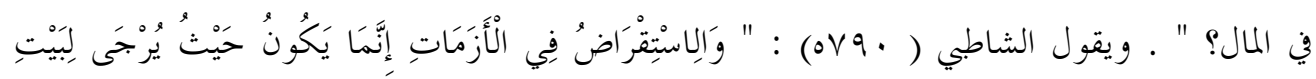




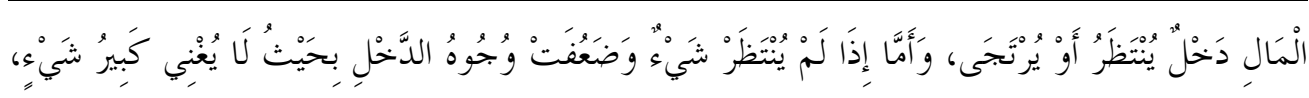

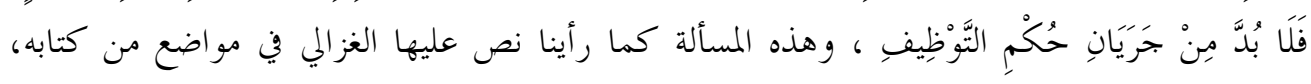
وتلاه في تصحيحها ابن العربي ، وشرط جواز ذلك كله عندهم عدالة الإمام، وإيقاع التصرف في أخذا لئ

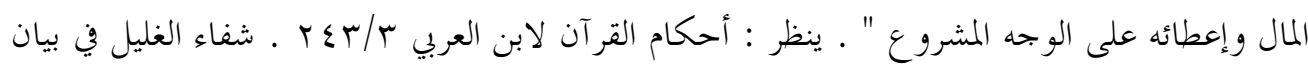

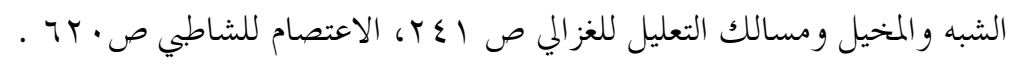

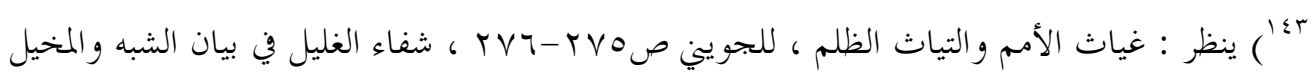

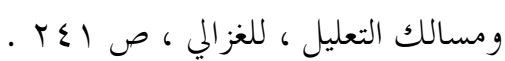

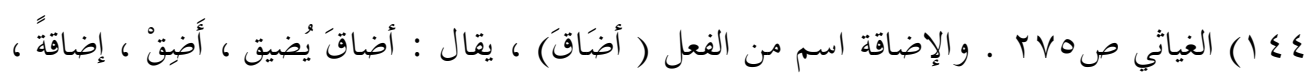

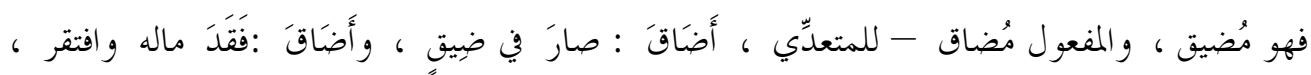

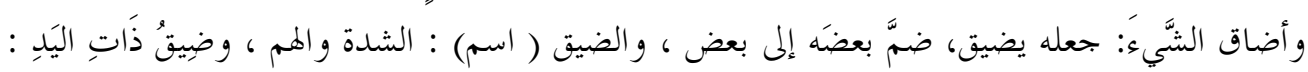

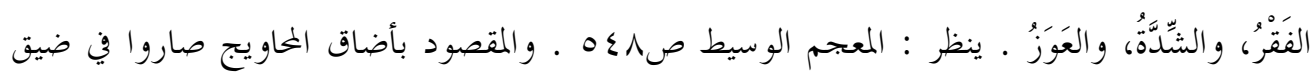
وفقر ، و المراد بفرض الإضاقة أي ضم المحاويج إلى غيرهم ليطعموهم ويكفوهم .

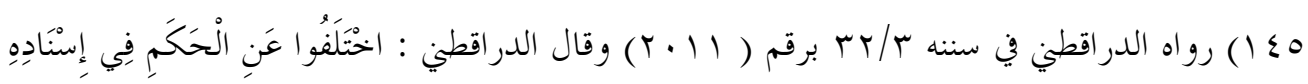

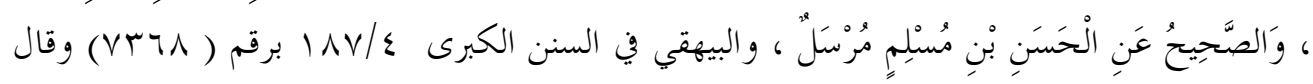

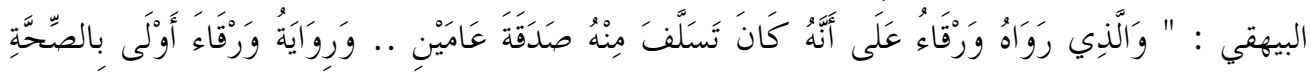

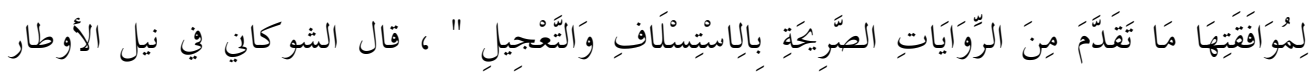

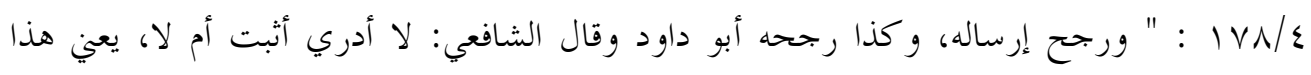

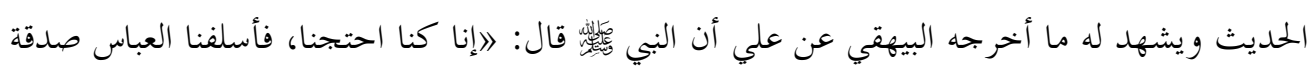

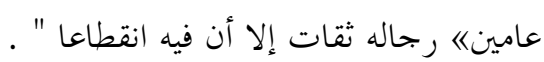

$$
\text { r rV TVT- rVO }
$$

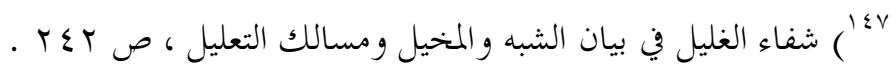

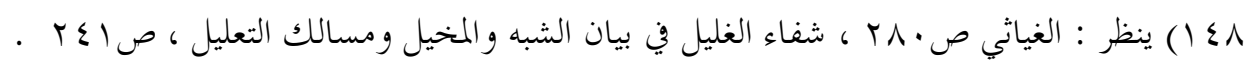

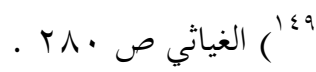

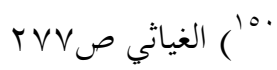

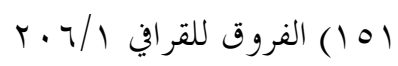

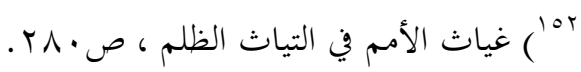




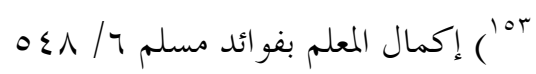

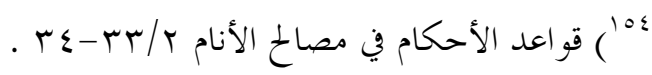

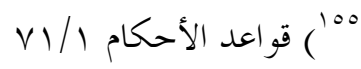

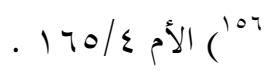

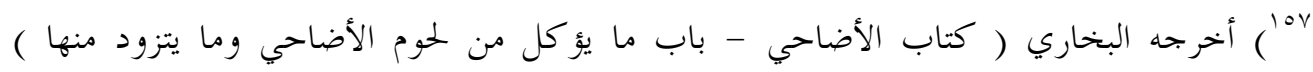

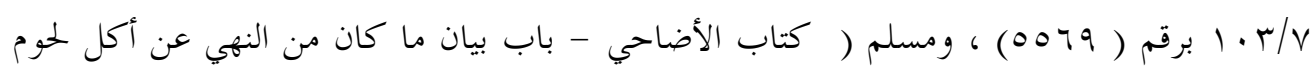

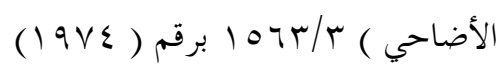

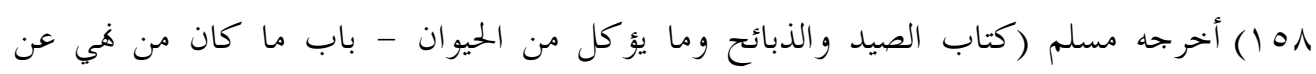

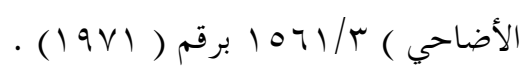

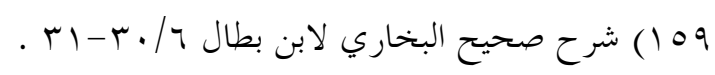

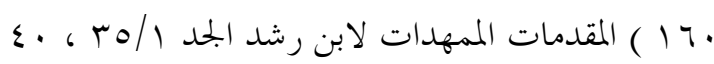
$9 \varepsilon / 0$ (المات

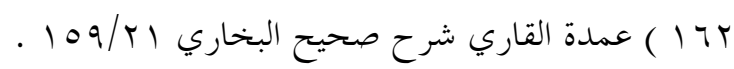

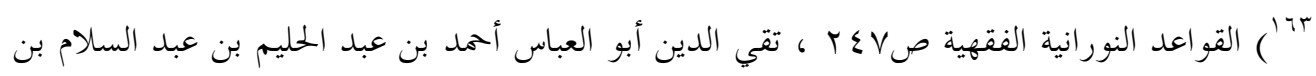

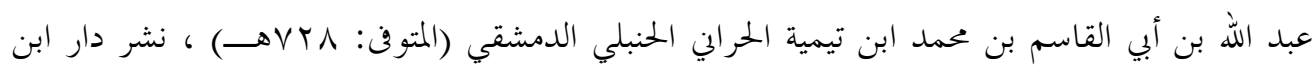

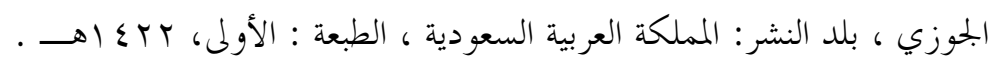

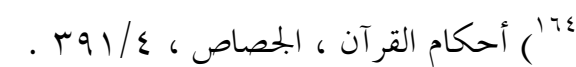

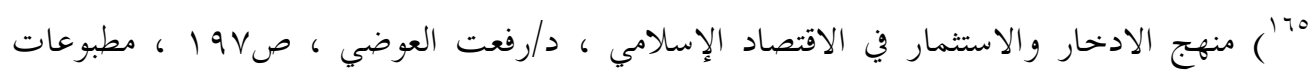
الاتحاد الدولي للبنوك الإسلامية ، القاهرة .

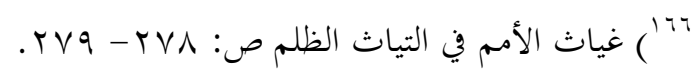

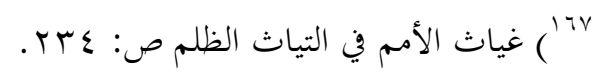

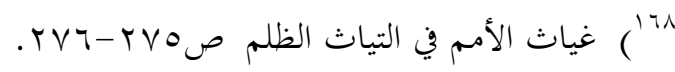

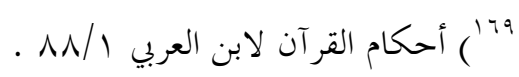

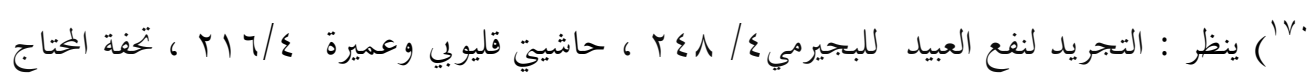

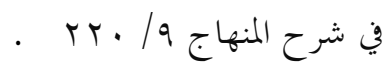


اVI العدالة تعني الصلاح في الدين ، أو تعني أن يكون الإمام ( رئيس الدولة ) صادق اللهجة، ظاهر

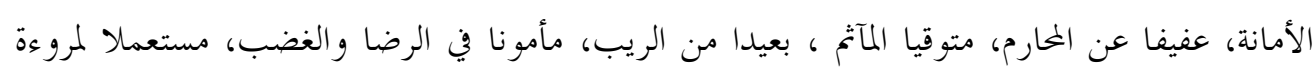

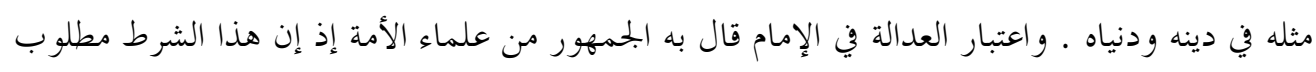
في الشاهد و القاضي ولا شك أن الإمامة العظمى أعلى متزلة منهما ، و لم يخالف أحد الجمههور في القول

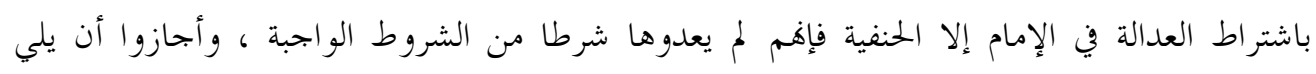

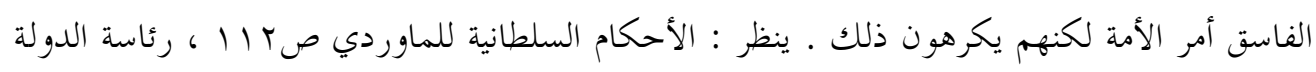

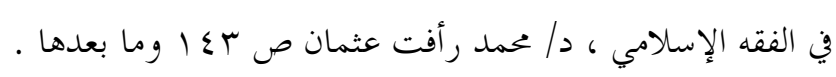

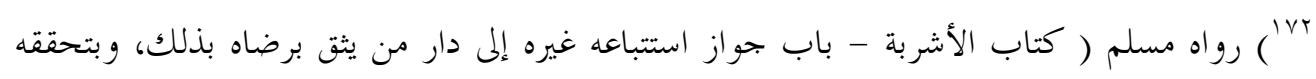

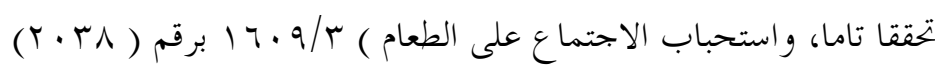

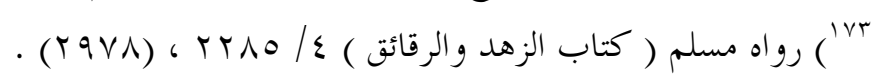

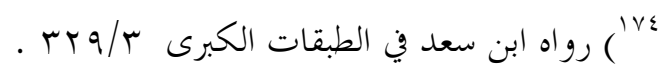

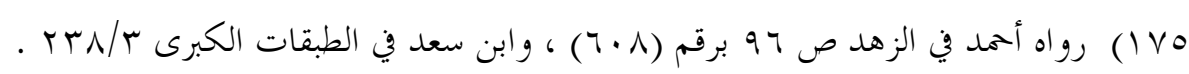

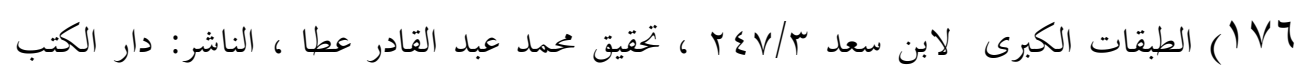
العلمية - بيروت ، الطبعة الأولى، · إ 1 هـ - - 199 م ، المعرفة والتاريخ ، يعقوب بن سفيان بن

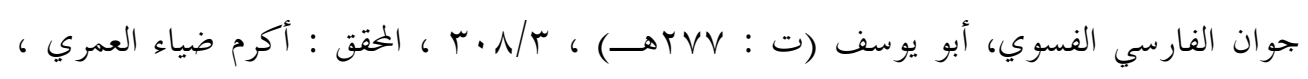

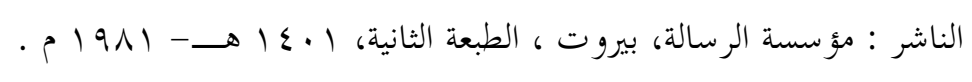

$$
\text { . }
$$

1 V ) وفيات الأعيان وأنباء أبناء الزمان ، لأبي العباس شمس الدين أحمد بن محمد بن إبراهيم بن أبي بكر

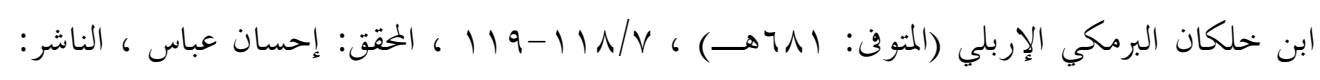

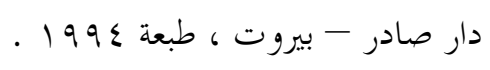

9 النجوم الزاهرة في ملوك مصر والقاهرة ، يوسف بن تغري بردي بن عبد الله الظاهري الحنفي، أبو

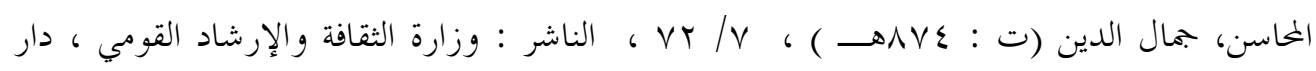

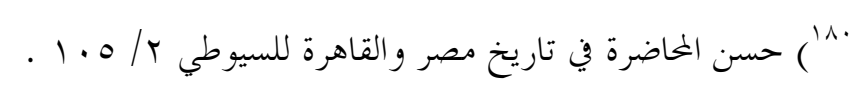

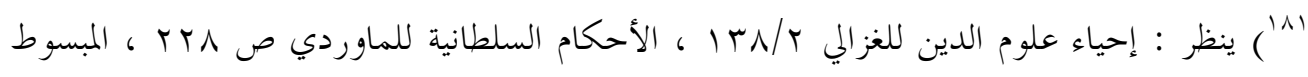

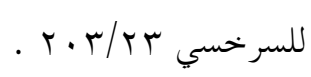




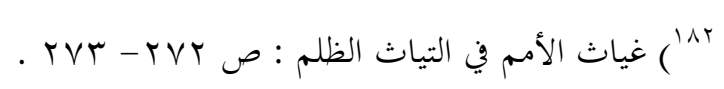

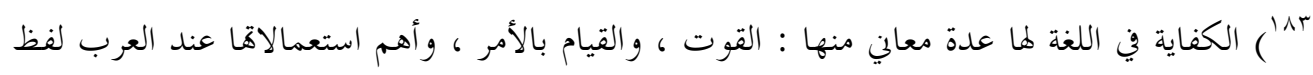
القوت الذي يطلق عند العرب على ما يسد الرمق من الطعام ، كذلك من معانيها الكفاف : وهو الذي لا يفضل عن الشيء ويكون بقدر الحاجة ، وعند فقهاء الحنفية الكفاية هي حاجات الإنسان الأصلية

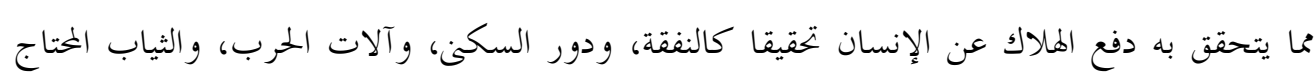

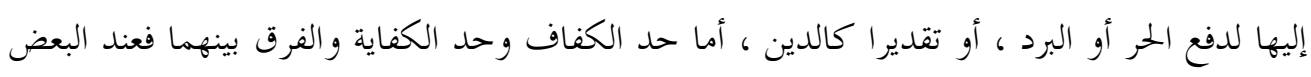
كالإمام النووي حد الكفاية يساوي حد الكفاف حيث يرى أن الكفاف هو الكفاية بلا زيادة ولا نقص

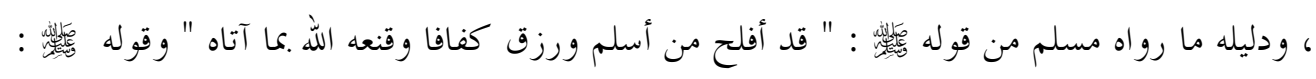

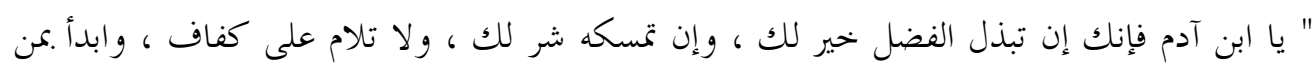

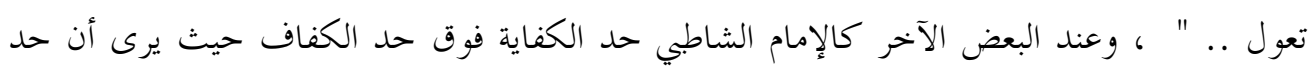

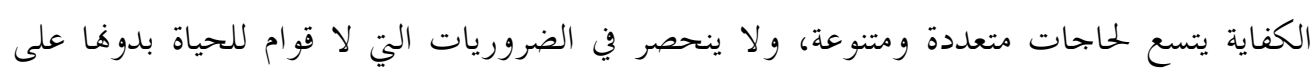
العكس من حد الكفاف، إذ إن حد الكفاف يكون مقتصرا على الضروريات التي لا قو ام لحياة الأفراد

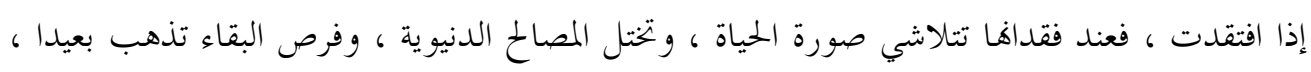

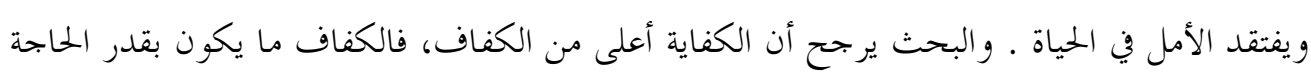

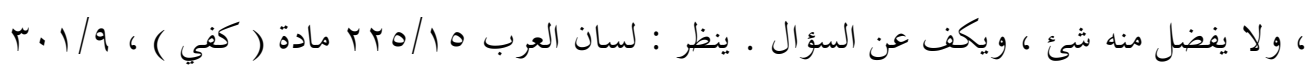

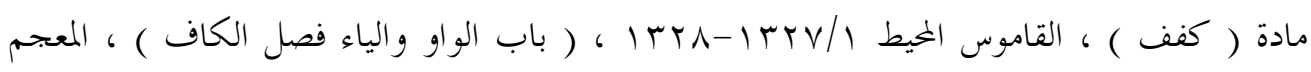

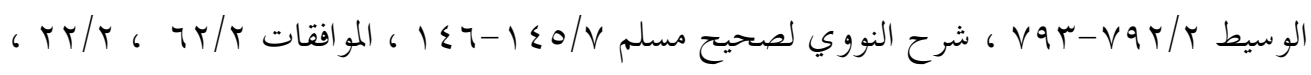

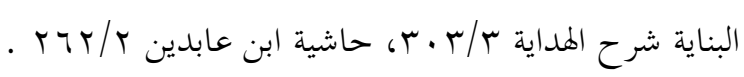

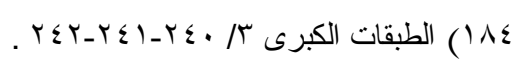

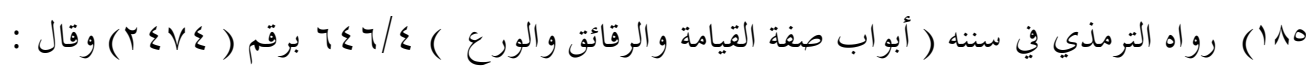
حديث صحيح ·

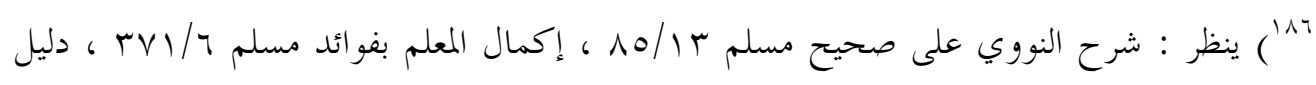

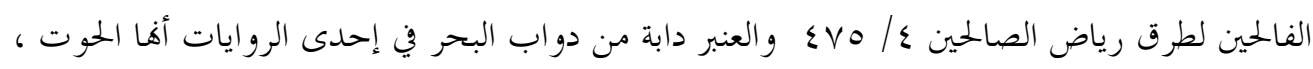
و وي رواية مسلم " فرفع لنا على ساحل البحر كهيئة الكثيب الضخم، وإذا به دابة تدعى العنبر " . • ا I NVV

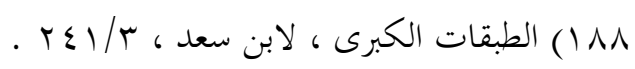

